UNIVERSIDADE DE SÃO PAULO

PROGRAMA DE PÓS GRADUAÇÃO EM CIÊNCIA AMBIENTAL

\title{
LICENCIAMENTO AMBIENTAL \\ NO BRASIL SOB A PERSPECTIVA \\ DA MODERNIZAÇÃO ECOLÓGICA
}

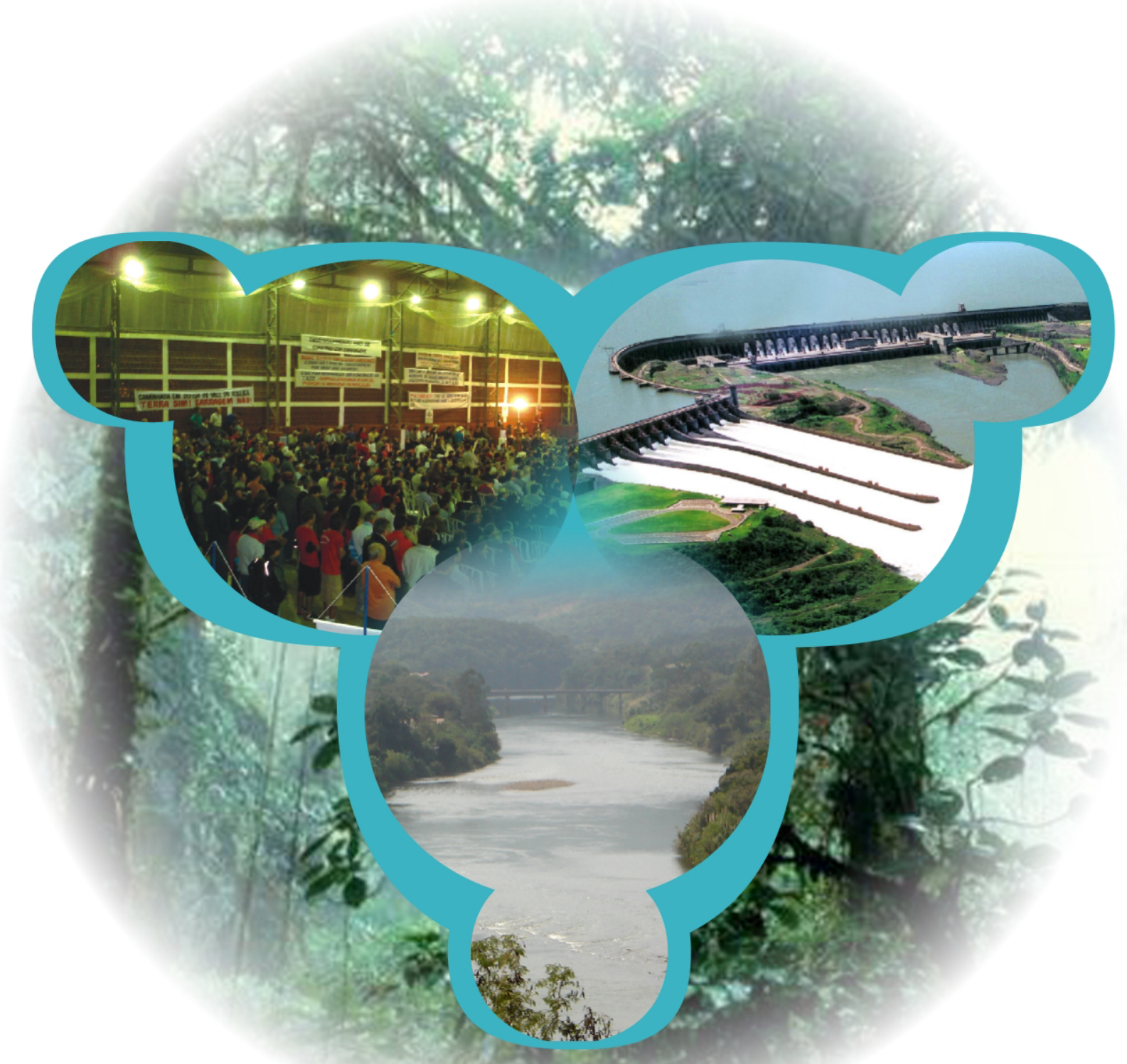

Alexandre do Nascimento Souza

Orientador: Prof ${ }^{\circ} \mathrm{Dr}^{\circ}$ Pedro Roberto Jacobi

São Paulo

2009 



\title{
UNIVERSIDADE DE SÃO PAULO
}

PROGRAMA DE PÓS-GRADUAÇÃO EM CIÊNCIA AMBIENTAL

\section{LICENCIAMENTO AMBIENTAL NO BRASIL SOB A PERSPECTIVA DA MODERNIZAÇÃO ECOLÓGICA}

\author{
Alexandre do Nascimento Souza \\ Orientador: $\operatorname{Prof}^{\mathrm{o}}$ Dr $^{\mathbf{o}}$ Pedro Roberto Jacobi
}

São Paulo

2009 


\begin{abstract}
Alexandre do Nascimento Souza
Licenciamento Ambiental no Brasil sob a perspectiva da Modernização Ecológica
\end{abstract}

Dissertação apresentada ao Programa de Pós-Graduação em Ciência Ambiental da USP para obtenção do título de Mestre em Ciência Ambiental

Área de Concentração: Planejamento, Conservação e Desenvolvimento Socioambiental

Orientador: Pedro Roberto Jacobi

São Paulo

2009 


\section{Folha de Aprovação}

Alexandre do Nascimento Souza

Licenciamento Ambiental no Brasil sob a perspectiva da Modernização Ecológica

Dissertação apresentada ao Programa de Pós-Graduação em Ciência Ambiental da Universidade de São Paulo para obtenção do título de Mestre em Ciência Ambiental

Aprovado em:

Banca Examinadora:

$\operatorname{Prof}^{\circ} \operatorname{Dr}^{\circ}$

Instituição Assinatura

$\operatorname{Prof}^{\circ} \operatorname{Dr}^{\circ}$

Instituição Assinatura

$\operatorname{Prof}^{\circ} \operatorname{Dr}^{\circ}$ Instituição Assinatura 

Aos Brasileiros que acordam todos os dias para fazer do Brasil um país digno e justo. 


\section{Agradecimentos}

Uma dissertação de mestrado ainda que seja um trabalho autoral não se viabiliza sem a contribuição e o entusiasmo de muitas pessoas.

Nesse sentido, efusivamente agradeço ao meu orientador $\operatorname{Prof}^{\circ}$ Dr ${ }^{\circ}$ Pedro Roberto Jacobi pela qualidade da orientação e precisão dos caminhos indicados. Por sua generosidade e paciência. Pelas palavras de estímulo e a maneira ética com a qual conduziu a orientação. Saúdo a forma madura e respeitosa que imprimiu à nossa relação.

Agradeço ao $\operatorname{Prof}^{\circ} \operatorname{Dr}^{\circ}$ Edmir Perrotti, quem me iniciou na pesquisa acadêmica e também com muita competência, paciência e generosidade me ajudou a dar os primeiros passos no mundo da ciência.

Agradeço ao $\operatorname{Prof}^{\circ}$ Dr $^{\circ}$ Célio Bermann pelo estímulo e incentivo já nos primeiros momentos desse processo.

Agradeço aos professores que fizeram parte dos comitês de orientação e que deram valorosas contribuições, sem as quais esse trabalho não teria a qualidade que tem: $\operatorname{Prof}^{\mathrm{a}} \mathrm{Dr}^{\mathrm{a}}$ Ana Paula Francalanza, Prof $^{a}$ Dr $^{\mathrm{a}}$ Mônica Porto, Prof $^{\mathrm{o}}$ Dr $^{\mathrm{o}}$ Joel Sigolo e o Prof ${ }^{\mathrm{o}} \operatorname{Dr}^{\mathrm{o}}$ Luiz Carlos Beduschi.

Agradeço a Prof ${ }^{a}$ Dr $^{a}$ Julia Guivant e ao $\operatorname{Prof}^{\circ} \operatorname{Dr}^{\circ}$ Luiz Carlos Beduschi pela disponibilidade e participação da banca de avaliação da dissertação. Acredito que a excelência da participação mais que coroam todo o processo

Agradeço as valiosas conversas, sugestões e indicações da $\operatorname{Prof}^{\mathrm{a}} \operatorname{Dr}^{\mathrm{a}}$ Neli Aparecida de Mello e do Prof $^{\circ}$ Dr $^{\circ}$ Evandro Moretto, professores que me deram a oportunidade de ser bolsista do Programa de Aperfeiçoamento de Ensino em suas disciplinas no curso de Gestão Ambiental da USP e também me ajudaram a refletir a dissertação.

Agradeço ao $\operatorname{Prof}^{\circ} \operatorname{Dr}^{\circ}$ Arlei Benedito a boa conversa, as indicações e ajuda junto a lideranças sociais do Vale do Ribeira, sobretudo da Câmara Técnica do Comitê de Bacia Hidrográfica do Rio Ribeira do Iguape, que também cumprimento pelo pronto acolhimento.

Durante os três anos da pesquisa contei com inúmeras colaborações diretas de fora da academia sem as quais tudo teria sido mais difícil. Agradeço a forma prestativa e cortêz que encontrei nos servidores do IBAMA a quem agradeço ao me referir ao Adriano Queiróz, analista ambiental. Agradeço também aos servidores do Ministério do Meio Ambiente e Ministério das Minas e Energia que ao contrário do que se tem convencionado a respeito do funcionalismo público foram gentis e generosos ao disponibilizar inúmeros documentos dos quais me vali na dissertação.

Agradeço as entrevistas concedidas pela Procuradora Geral da República, Maria Luiza Grabner, pelo ex-secretário executivo do Ministério do Meio Ambiente, Cláudio Langone; a Coordenadora de Recursos Hídricos e Ambientais do Ministério das Minas e Energia, Márcia Camargo; ao diretor de Planejamento da Abdib, Giancarlo Gerli; ao ex-diretor de Licenciamento Ambiental do IBAMA, Walter Muchagata; ao conselheiro do Conama e Vice-presidente de Engenharia e Meio Ambiente do Grupo Rede, Décio Michellis Jr; a Raul Telles do Valle, advogado do Instituto Sócio Ambiental - ISA; a Ronaldo Crusco, consultor da CNEC e responsável pela equipe que elaborou o projeto técnico e EIA da UHE Tijuco Alto; a Jonas Dias Batista, prefeito de Ribeira e Ronaldo Ribeiro, diretor do IDESC.

Agradeço a Laura Jesus do CEDEA a conversa informal e a carona de Ribeira a Eldorado durante o ciclo de audiências. 
Agradeço as lideranças quilombolas do $\mathrm{MOAB}$ e aos ativistas do Coletivo Educador do Lagamar de Cananéia e Iguape pela disponibilidade quando procurados por mim e aos últimos a acolhida em Cananéia, quando tive a oportunidade de conhecer parte do complexo estuarino, lugar lindo.

Agradeço aos companheiros do Observatório Brasileiro de Mídia, em especial Kjeld Jakobsen, Carlos Tibúrcio e o Prof ${ }^{\circ} \operatorname{Dr}^{\circ}$ Bernardo Kucinski que sempre me incentivaram e me permitiram as condições necessárias para que chegasse até aqui, mesmo trabalhando.

Agradeço ao meu amigo de infância Rodrigo Yamashita, que com seu talento de diagramador me ajudou a tornar todo o trabalho mais palatável.

Finalmente, agradeço o apoio recebido pela CPG do PROCAM, pelo insubstituível apoio dos servidores da secretaria do programa e pelo constante diálogo, estímulo, curiosidade e amizade dos meus colegas do programa, também alunos pós-graduandos. 


\section{Declarações}

No curso dos três anos da pesquisa muitos acontecimentos na minha vida pessoal incidiram de tal forma sobre mim que é impossível não reconhecer o impacto destes sobre o resultado final do trabalho, até porque nos momentos difíceis entendi que os compromissos assumidos que tinha não poderiam caducar devido as intempéries ou alegrias que a vida me proporcionou.

Os melhores momentos desse processo, quando João nasceu. Fonte de luz, força e alegria todos os dias. A companhia, amizade e curiosidade diária de Gabriel, sua compreensão e seu eterno carisma e equilíbrio. O exemplo, a paciência, doçura e amor de Camila, minha gata, amiga e companheira.

Divido a alegria da conclusão desse texto com todos aqueles que mesmo muito distantes sempre estarão comigo: minha filha, Ana Vitória, meu pai Geraldo Souza e meu avô Diógenes Ribeiro, além dos meus amigos Alfredo Lopes Filho, Rodrigo Epov de Almeida Prado e Leodito (Brasília) que sempre estiveram a orientar minha vontade de concluir esse tex to do qual também são parte.

Impossível chegar ao final dessa pesquisa sem a certeza do amor, o exemplo de vida e estímulo, além do investimento e principalmente paciência de minha mãe, Maria Zenaide, meu pai Geraldo, meu padastro Vladimir Oganauskas e minhas avós, Maria Josefa e Eozina Ribeiro, além de D. Dirse. Sem o carinho, alegria, incentivo e força das minhas irmãs Gabriela e Ana Carolina e meus irmãos, André, Vladimir, Igor e Bruno, talvez não fosse possível estar longe de todos.

Sempre contei com o apoio de tias, tios, primas e primos, especialmente minha tia Sônia, primeira cientista humana e social que conheci, um excelente exemplo. Meus tios Gidevaldo e Gildásio que me ajudaram no início desse processo, quando precisei de apoio para entrar na USP e vir a São Paulo. Meu tio Souza, um grande amigo na falta de meu pai, assim como ele, um grande entusiasta dos meus sonhos. Minhas tias Lili, Margarida, Telma e Regina. Meus tios Diógenes Filho e Ari, sorridentes e brincalhões, sempre amigos

Meus primos Toco e Juca, tanto primos quanto irmãos, estiveram uma temporada em São Paulo em busca de seus sonhos e mais uma vez foram grandes companheiros, amigos e irmãos. Meus amigos Guilherme e Manuca, companheiros de jornada e bons papos. Minhas primas Ana Luíza, Juliana, Luciana, Júlia, Daise, Damaris, Vitória, Natália e Cecília. Meus primos Genaro, Leleco, Neemias, Nahum, Natam, Felipe, Genivaldo e Gerinaldo que mesmo distantes sempre me mandaram vibrações de apoio e carinho.

Minhas sobrinhas Catarina e Janaína e meus sobrinhos Lucas e Samuel, tão preciosos e inspiradores quanto meus filhos.

Longe de meu primeiro núcleo familiar, sempre contei com minha sogra, Maria Tereza; meu sogro José Carlos, minha vó nova Conceição e cunhados Alváro e Adriano, além da força e ajuda de Jacira e Maria. Sem Sueli tudo seria mais difícil.

Na Bahia e em São Paulo, meus colegas da Escola Técnica Federal da Bahia, precursores da vinda para a USP e UNICAMP, com quem sempre contei e tive acolhimento: Barbosa, Dedeco, Glauber, Humberto, Luiz Miranda, Machadão e Zé Mário. Nossa amiga Tonha e sua culinária que muitas vezes, mesmo em Campinas, nos trouxe a lembrança gostosa dos sabores da Bahia.

NA FFLCH/USP a "Galera do Bosque", uma turma de tantos seres tão especiais que é impossível citá-los nominalmente sem comentar a riqueza e beleza desses meus amigos do barulho e do silêncio. Estas páginas não caberiam. Por hora, me sinto convencido, por iniciativa desses parceiros de jornada, que sou Alebaiano, o soteropaulistano. 


\section{Resumo}

Souza, Alexandre Nascimento Licenciamento Ambiental no Brasil sob a perspectiva da Modernização Ecológica. 2009. Dissertação (Mestrado) - Programa de Pós-graduação em Ciência Ambiental - PROCAM, São Paulo, 2009.

OLicenciamento ambiental é um dos instrumentos da Política Nacional de Meio Ambiente, estabelecida pela lei 6.938 de 1981. Nos últimos 30 anos, o país passou por inúmeras transformações econômicas, políticas e sociais. No cenário de grande potencial hidrelétrico do país, demanda crescente por energia, fortalecimento e consolidação da legislação e do sistema de gestão ambiental, participação de novos atores econômicos interessados em prover a expansão do parque de geração de energia, maior participação dos movimentos sociais na esfera pública e uma memória não muito distante de graves problemas socioambientais ocasionados pela construção de hidrelétricas; é que se dão os conflitos que perpassam todo o processo de licenciamento ambiental de hidrelétricas e do qual se ocupa essa dissertação. Entre os anos de 2004 e 2008, muitos atores econômicos e sociais envolvidos com a temática do licenciamento ambiental no país se posicionaram publicamente, sobretudo a respeito dos conflitos relacionados à concessão das licenças ambientais para empreendimentos hidrelétricos. A reflexão sociológica a qual se propôs este projeto de pesquisa utiliza a "Teoria da Modernização Ecológica" como instrumental teórico e busca entender o estado da arte do licenciamento ambiental de hidrelétricas no Brasil.

Palavras-chave: Modernização Ecológica. Licenciamento Ambiental. Hidrelétrica. 


\begin{abstract}
The Environmental license is one of the tools of the National Environmental Policy, established by the law 6.938 of 1981 . Over the past 30 years, the country has had lots of economical, political and social changes. The socio-environmental conflicts that permeate the environmental licensing process of UHEs, which constitute the subject of this dissertation, happen in a context characterized by the great hydroelectric potential of the country, the increasing demand for energy, the strengthening and consolidation of the legislation and of the environmental management system, the growing participation of the social movements in the public sphere, a recent memory of socio-environmental problems resulting from the construction of hydroelectric power stations and the participation of new economic agents interested in promoting the expansion of the energy generation park. Between 2004 and 2008, many economical and social agents that were involved with environmental licensing subjects in Brazil publicly expressed their positions, mainly in relation to the conflicts related to environmental license concession for hydroelectric enterprises. The sociological analysis of this research project uses the "Ecological Modernization Theory" as a theoretical instrument. It also aims to understand the environmental licensing process for hydroelectric power stations in Brazil.
\end{abstract}

Key-words: Ecological Modernization, Environmental Licensing, Hydroelectric Power Station. 


\section{Lista de Abreviaturas}

AAE - Avaliação Ambiental Estratégica

AAI - Avaliação Ambiental Integrada

ABAVAR - Associação do Bananicultores do Vale do Ribeira

ABDIB - Associação Brasileira da Indústria de Base

AIA - Avaliação de Impacto Ambiental

ANEEL - Agência Nacional de Energia Elétrica

AP - Audiência Pública

ASSTRAF - Associação Sindical dos Trabalhadores na Agricultura Familiar

BNDES - Banco Nacional do Desenvolvimento

CBA - Companhia Brasileira de Alumínio

CEDEA - Centro de Estudos, Defesa e Educação Ambiental

CNEC - Consórcio Nacional de Engenheiros Consultores

CONAMA - Conselho Nacional do Meio Ambiente

CONSAD- Conselho de Segurança Alimentar do Vale do Ribeira

EIA - Estudo de Impacto Ambiental

FBOMS - Fórum Brasileiro de ONG’s e Movimentos Sociais para o Meio Ambiente e Desenvolvimento

GTE - Grupo de Trabalho de Energia

IBAMA - Instituto Brasileiro do Meio Ambiente

IDESC - Instituto para o Desenvolvimento Sustentável e Cidadania do Vale do Ribeira

IFC - International Finance Corporation

ISA - Instituto Socioambiental

ISE - Índice de Responsabilidade Social

MAB - Movimento dos Atingidos por Barragens 
ME - Modernização Ecológica

MMA - Ministério das Minas e Energia

MME - Ministério das Minas e Energia

MOAB - Movimento dos Ameaçados por Barragens

MP - Ministério Público

MST - Movimento dos Sem Terra

PIB - Produto Interno Bruto

PNMA - Política Nacional de Meio Ambiente

RIMA - Relatório de Impacto Ambiental

SINDISAÚDE - Sindicato dos Servidores da Saúde

SISNAMA - Sistema Nacional do Meio Ambiente

TAC - Termo de Ajuste de Conduta

TR - Termo de Referência

UHE - Hidrelétrica

UTE - Termelétrica 


\section{Lista de Tabelas e Figuras}

\section{TABELAS}

Tabela 1 - Relação entre hora da intervenção e posição em relação à UHE .................................... 173

Tabela 2- Participação dos atores sociais sobre conjunto das intervenções ..................................175

Tabela 3- Município de origem dos cidadãos que interviram por Audiência ...................................177

Tabela 4 - Posição em relação à UHE a partir das intervenções ................................................ 180

Tabela 5 - Sentidos Construídos com mais frequiência pelos interesses locais ............................... 181

Tabela 6 - Sentidos Construídos pela CBA/CNEC .................................................................... 182

Tabela 7 - Sentidos construídos mais frequentes pelo Coletivo de Educadores do Lagamar ....... 184

Tabela 8 - Sentidos construídos mais frequentes pelo MOAB ............................................... 185

\section{FIGURAS}

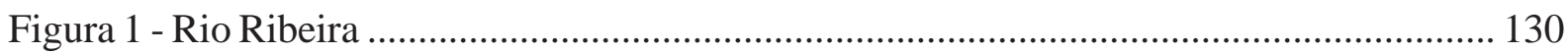

Figura 2 - Principais Municípios da Bacia Hidrográfica do Rio Ribeira de Iguape ....................... 131

Figura 3 - Municípios do Vale do Ribeira no Paraná ...................................................................132

Figura 4 - Municípios do Vale do Ribeira em São Paulo .............................................................. 133

Figura 5 - Atrativos Naturais do Vale do Ribeira em São Paulo ................................................. 134

Figura 6 - Mapa das Unidades de Conservação do Estado de São Paulo .................................. 134

Figura 7 - Mapa das Unidades de Conservação e AID da UHE Tijuco Alto ................................... 135

Figura 8 - Índice de Desenvolvimento Humano - São Paulo ..................................................... 135

Figura 9 - Índice de Desenvolvimento Humano - Paraná ......................................................... 136

Figura 10 - Tipologia Socioeconômica, Agrícola e Ambiental do Vale do Ribeira ......................... 137

Figura 11 - Mapa das UHE`s inventariadas para o Rio Ribeira ................................................ 140

Figura 12 - Ato contrário a UHE na abertura da COP-8 em Curitba ....................................... 147

Figura 13 - Movimento Social ocupa sede do IBAMA em São Paulo ........................................ 147

Figura 14 - Evolução da Produção de Alumínio no Brasil ........................................................... 149

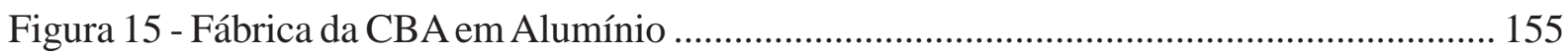

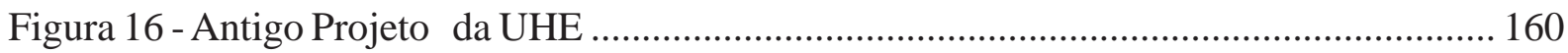

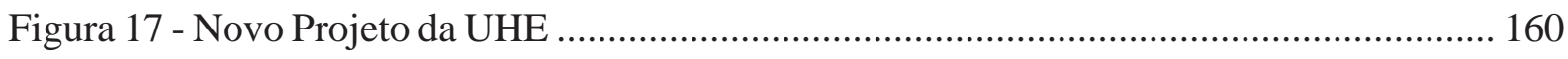


Figura 18 - Mapa dos terrenos adquiridos pela CBA na década de 90 ..................................... 162

Figura 19 - Mapa Populacional do Vale do Ribeira/São Paulo ................................................... 163

Figura 20 - Audiências Públicas no início dos debates e algumas horas depois ........................... 171

Figura 21 - Área de Influência Direta (AID) e Área Diretamente Afetada .................................... 178

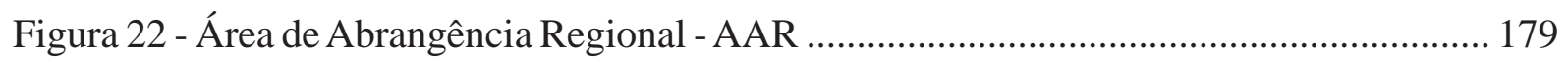

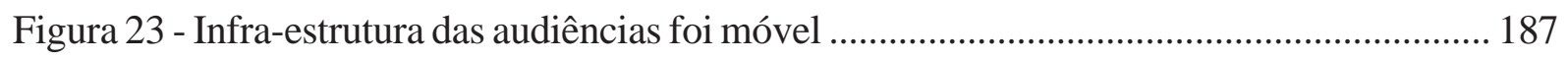

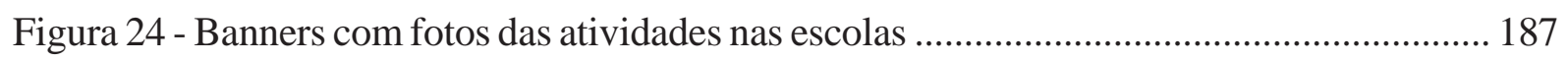

Figura 25 - Bancada com foto aérea da Área de Influência Direta - ......................................... 187

Figura 26 - A Audiência em Cerro Azul …………................................................................... 192

Figura 27 - Faixas Padronizadas de Apoio ao empreendimento ................................................... 194

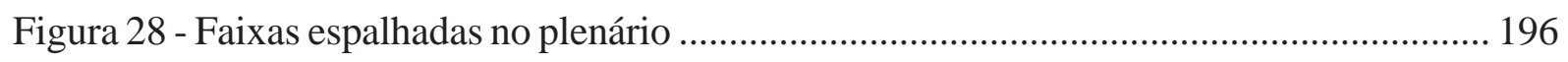

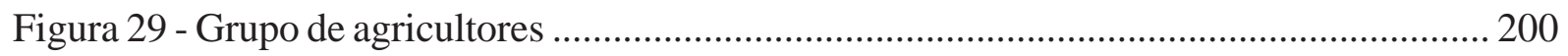

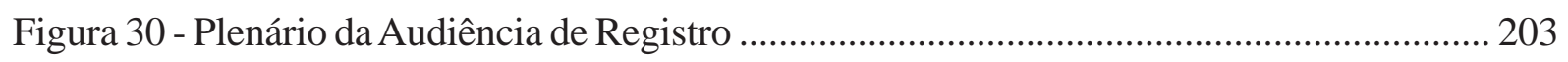

Figura 31 - Faixas favoráveis ao empreendimento no auditório em Registro ................................. 204 


\section{Sumário}

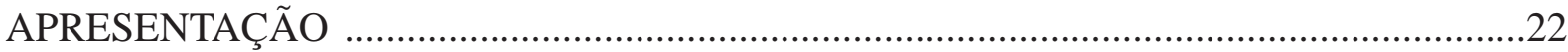

1 MODERNIZAÇÃO ECOLÓGICA EM PERSPECTIVA ………………………………….... 34

1.1 Primeiro Cenário - O debate ambiental e a modernidade ............................................. 34

1.1.1 Do Paradigma da Excepcionalidade Humana à Ecologia como Novo Paradigma -

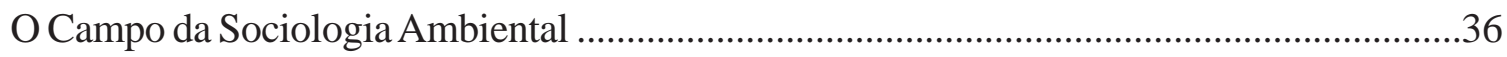

1.2 Segundo Cenário - A Eminência de uma Teoria Ambiental Global ................................39

1.3 A Modernização Ecológica - ME ................................................................... 42

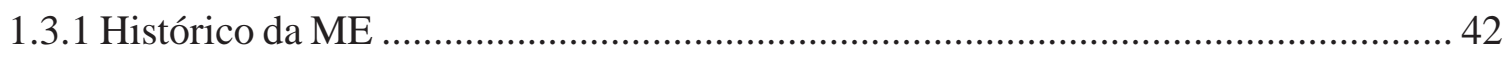

1.3.2 Principais Pressupostos da Modernização Ecológica ............................................... 45

1.3.3 A Modernização Ecológica em 5 pontos ............................................................ 47

1.3.4 Crise e Reforma Ambiental no Brasil - Qual o papel da Modernização Ecológica? ........ 49

1.3.5 Modernização Ecológica como Aprendizagem Social ........................................... 50

1.3.6 Modernização Ecológica e o setor de infra-estrutura no Brasil .............................. 52

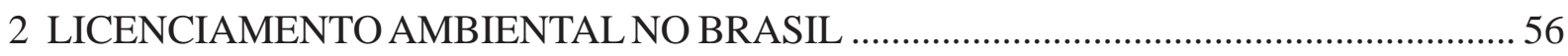

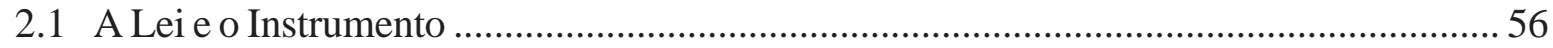

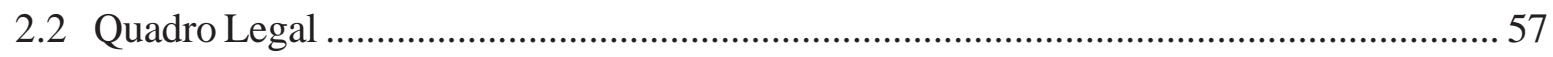

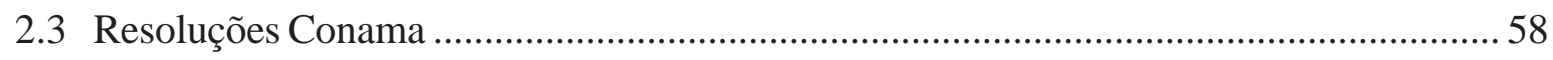

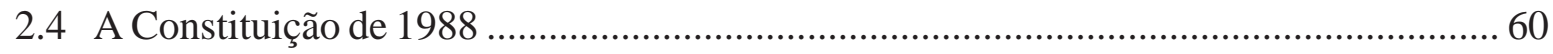

2.5 Licenciamento Ambiental de Hidrelétricas - AControvérsia ........................................... 61

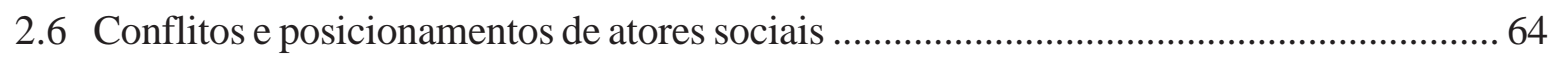

2.7 Outras Opiniões: O que dizem os atores, sujeitos da controvérsia .................................... 69

2.8 "Licenciamento Ambiental de Empreendimentos Hidrelétricos no Brasil: Uma Contribuição

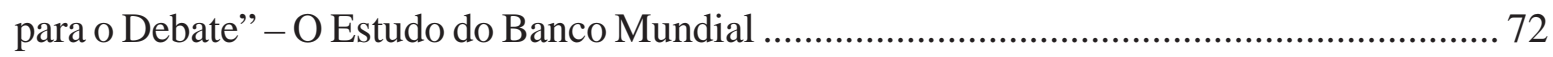

2.8.1 Licenciamento Ambiental e o dilema da maior participação social ................................ 75

2.8.2 O Tempo da Licença - IBAMA fragilizado X Estudos de Impacto ruins ....................... 77

2.8.3 Conflitos Socioambientais - Licenciamento Ambiental, Política Pública ou Fórum de

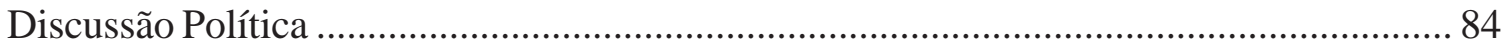

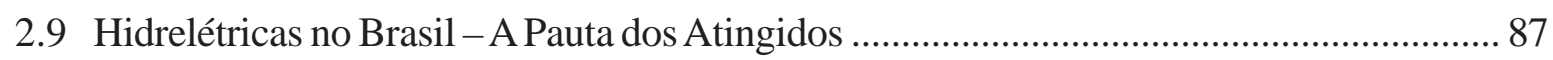


2.10 Viabilidade ambiental é parte da estratégia de negócio - A posição da Associação Brasileira da

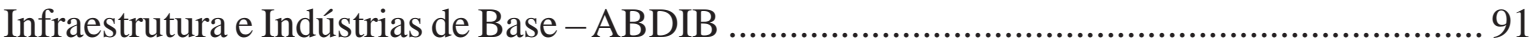

2.11 Sistema Financeiro e o desenvolvimento da infra-estrutura ............................................. 93

2.12 Mais participação social e transparência aumentam a legitimidade do processo de licenciamento:

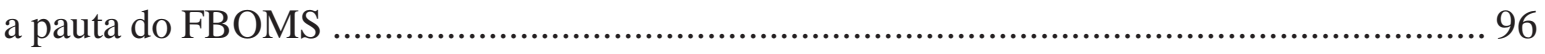

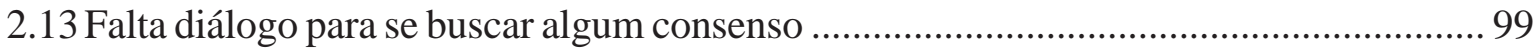

\section{LICENCIAMENTO AMBIENTAL NO BRASIL SOB APERSPECTIVADAMODERNIZAÇÃO}

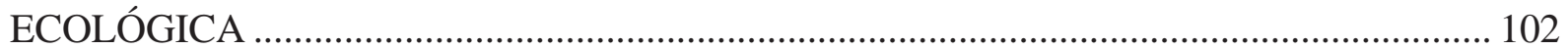

3.1 O Contexto da Lei 6938/81 -A Política Nacional de Meio Ambiente ............................... 102

3.2 Licenciamento Ambiental é Modernização Ecológica - ME ................................................ 103

3.3 Conflitos ambientais ensejam diálogo - As opiniões são modos próprios de interpretar o mesmo problema . 110

3.4 Mais participação para equilibrar o jogo-Nas Audiências Públicas o projeto já está pronto ..... 112

3.5 O que "licenciar" - Um Acordo a construir ...................................................................... 119

3.6 Cooperação-Mais Modernização Ecológica para fortalecero Licenciamento Ambiental ........ 121

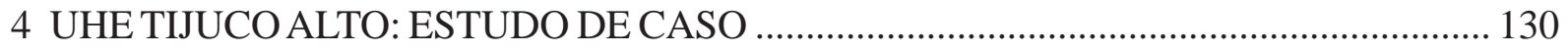

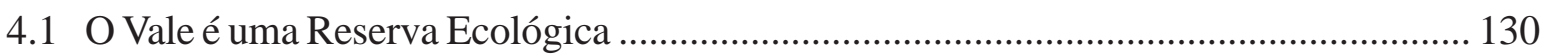

4.2 O Movimento Social no Vale do Ribeira - Breve Descrição ............................................ 139

4.2.1 OAproveitamento Hidrelétrico de Tijuco Alto e o Movimento Social no Vale do Ribeira ....... 143

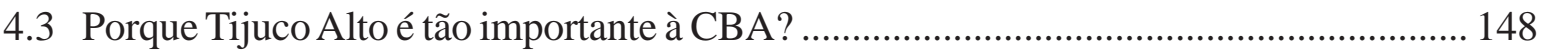

4.3.1 A indústria de Alumínio no Mundo: breve panorama ................................................. 148

4.3.2 A indústria de Alumínio no Brasil: um produto de exportação ...................................... 149

4.3.3 A indústria do alumínio e a construção de hidrelétricas ................................................. 151

4.3.4 Tijuco Alto e o parque hidrelétrico da CBA - Qualidade ambiental inferior às demais UHE's

4.3.5 CBAe Tijuco Alto - Mais energia, menor custo e independência energética ................. 154

4.4 AHidrelétrica Tijuco Alto-20 anos em licenciamento ................................................. 157

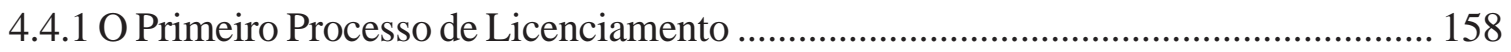

4.4.2 O Segundo Processo de Licenciamento …….............................................................. 159 
4.4.3 Mudanças no projeto técnico diminuíram impacto ambiental

4.4.4 Promessa de mudança no trato com os ameaçados pela barragem ............................... 161

4.5 Mudanças são reflexo do debate em torno do licenciamento ambiental .......................... 164

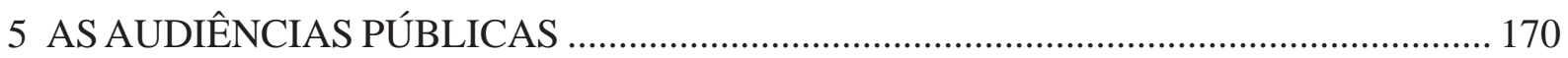

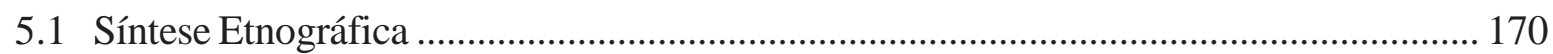

5.2 O Ciclo de Audiências - Um Circo Itinerante ................................................................. 186

5.2.1 É um Vale Rico - A audiência de Cerro Azul ........................................................... 192

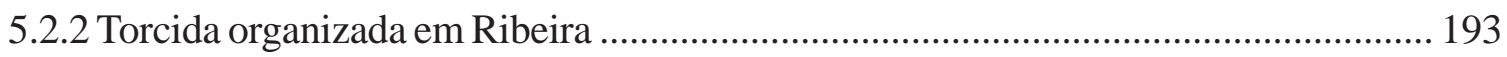

5.2.3 Tranquilidade do debate possibilitou um "footing” - A audiência de Adrianópolis ........ 195

5.2.4 Um "Circo" de casa cheia -A Audiência de Eldorado ................................................ 195

5.2.5 O balde entornou -A Audiência de Registro .......................................................... 201

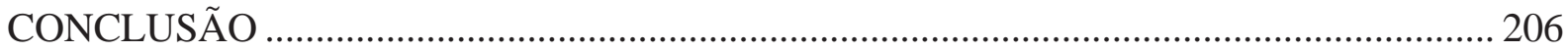

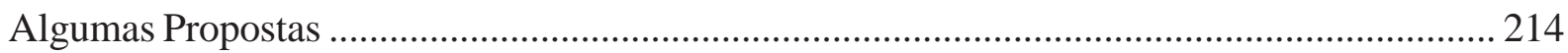

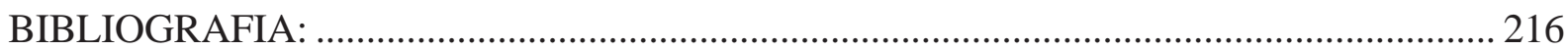





\section{APRESENTAÇÃO}

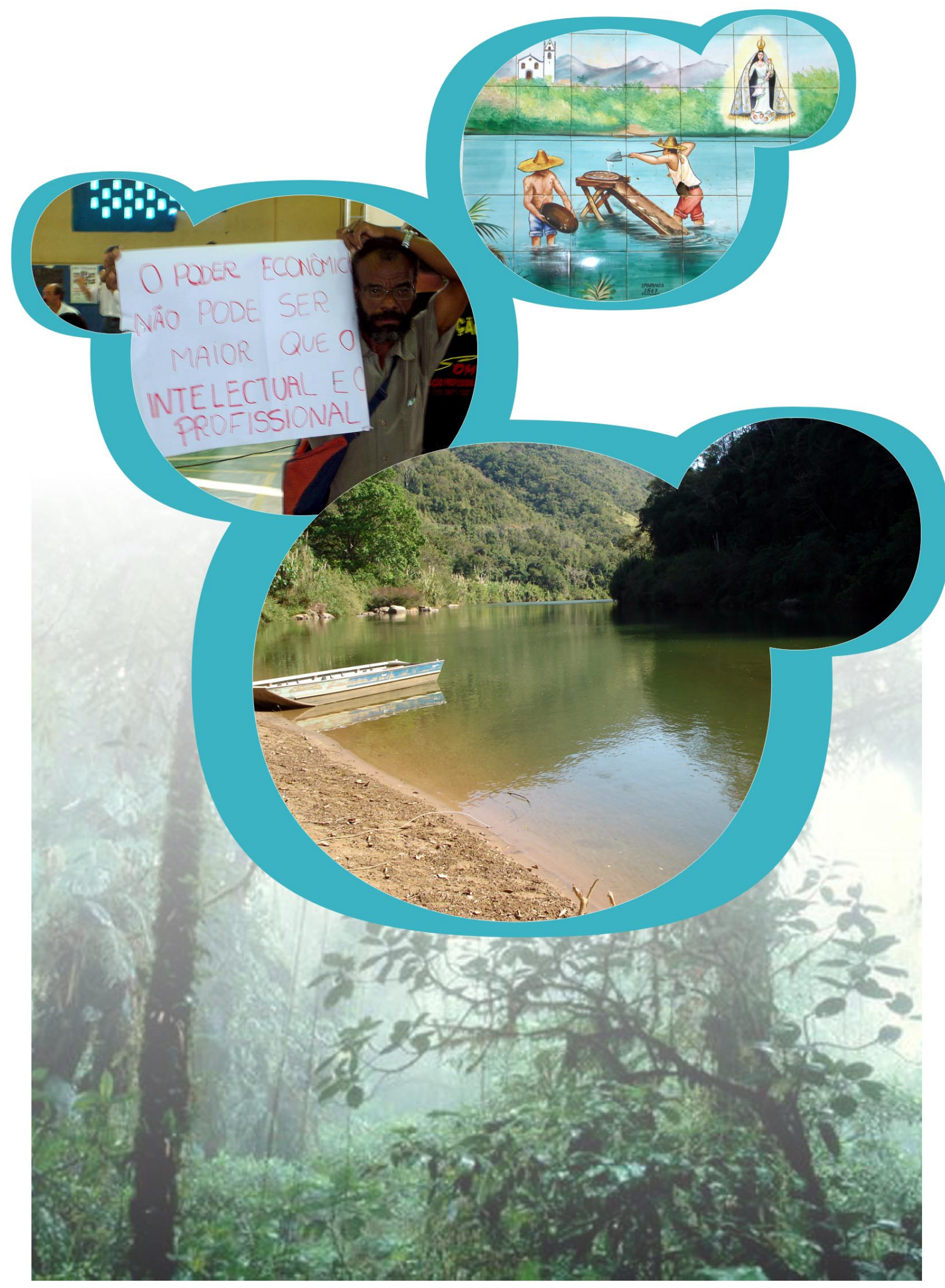




\section{Apresentação}

O trabalho que discutiremos nas próximas páginas é fruto da pesquisa “LicenciamentoAmbiental no Brasil: a perspectiva da Modernização Ecológica" desenvolvida junto ao Programa de Pós-Graduação em Ciência Ambiental da USP e busca cumprir os pré-requisitos necessários à obtenção do título de mestre.

A pesquisa teve início no primeiro semestre de 2006 e tem como objeto de reflexão o instrumento do licenciamento ambiental no Brasil.

O estudo tem como hipótese, o fato de que o processo de licenciamento ambiental tem sido um instrumento importante para a melhoria da qualidade ambiental dos empreendimentos de infra-estrutra, sobretudo as hidrelétricas. No entanto; a incorporação dos interesses locais ao processo de licenciamento só no momento da audiência pública, quando as principais decisões a respeito do empreendimento já estão tomadas (localização, arranjo técnico, diagnóstico socioambiental, concepção dos programas mitigatórios e compensatórios); dificulta o entendimento entre empreendedores, órgão licenciador e os interesses locais - poder público, movimento social e pessoas atingidas ou impactadas pelo empreendimento.

Os atores sociais locais não são consultados e nem chamados a dialogar em busca de um acordo que contemple suas demandas na fase de elaboração dos projetos, ao contrário, só irão debater a proposta no momento da audiência pública.

A apresentação tardia no processo de licenciamento ambiental das demandas políticas, administrativas, ambientais e econômico-sociais dos atores locais; quando o Estudo de Impacto Ambiental já está concluído, às vésperas da tomada de decisão do agente licenciador e a falta de detalhamento dos programas ambientais e sócio-econômicos destinados a compensar e mitigar os impactos dos empreendimentos; cria um ambiente de dúvidas e incertezas para aqueles que terão suas vidas interferidas pela construção dos empreendimentos.

A falta de diálogo sistêmico entre os diversos atores no curso do processo de licenciamento cria uma série de ruídos - dúvidas, insatisfações, incompreensões sobre o projeto. A partir daí, só têm o mo- 
mento da audiência pública para que sejam equacionados, sobrecarregando-a e transformando-a em um espaço de embate e não de debate.

O licenciamento foi primeiramente instituído pela Lei 6.938/81, que criou a Política Nacional de Meio Ambiente. Em 1988, a Constituição brasileira ratificou o licenciamento por meio do artigo $225 \S 1^{\circ}$, ao prever a necessidade de estudo de impacto ambiental para atividades causadoras de significativa degradação ao meio ambiente.

A Constituição cidadã ratificou a importância do meio ambiente como bem de uso comum e institucionalizou a participação social em uma série de instâncias públicas, algumas decisórias e outras consultivas, de modo que o fortalecimento do movimento social esteve acompanhado da conquista da participação em diversos processos de discussão, formulação e implementação de políticas públicas.

A crescente participação dos movimentos sociais em fóruns, conselhos, comissões, etc trouxe para os espaços de discussão sobre as políticas públicas grupos sociais antes marginalizados que criaram uma cultura de reflexão sobre os desígnios das políticas públicas no país e reivindicação de direitos.

O licenciamento ambiental tem sido foco de muita controversa no país, e, nos últimos anos, frente à necessidade premente de investimentos no desenvolvimento da infra-estrutura, as controversas se expandiram dos gabinetes para o espaço público.

O instrumento tem sido noticiado em ambiente contínuo de crise, e quase sempre apresentado como um entrave ao desenvolvimento do país. O debate sobre desenvolvimento e meio ambiente no qual se insere a reflexão a respeito do licenciamento ambiental tem oposto setores da sociedade e não raro de governos, tanto na esfera federal, quanto nos governos estaduais.

De um lado, normalmente o movimento social, sobretudo os ambientalistas, quilombolas, comunidades indígenas, ribeirinhos, agricultores e trabalhadores atingidos ou impactados por empreendimentos, e do outro, empreendedores e setores do governo comprometidos, inclusive por determinação legal, com o desenvolvimento da infra-estrutura: portos, aeroportos, estradas, hidrelétricas, redes de transmissão de energia.

Dentre os setores econômicos com interface direta com o sistema de licenciamento ambiental; a geração de energia hidrelétrica tem sido uma das atividades onde os conflitos socioambientais tem tido 
visibilidade pública. Nos últimos anos foi tema de um rico debate que envolveu setores do governo federal, movimento social, associações empresariais e o Banco Mundial.

Os empreendimentos hidrelétricos são causadores de significativo impacto ambiental, motivo pelo qual foram listados pela resolução Conama 237/97 como passivos de serem licenciados.

Na história recente do país, a construção de hidrelétricas causou desastres ambientais como a UHE de Balbina. Criou problemas de difícil solução para milhares de pessoas que precisaram abandonar as terras onde moravam, trabalhavam e onde tinham sua rede de relações sociais constituída, sem que, na maioria das vezes, fossem ressarcidas de suas perdas.

O setor elétrico passou por duas grandes mudanças nos últimos 13 anos. Em 1995, no contexto das reformas que permitiram o investimento privado em setores até então restritos a investimentos e gestão estatal, ocorreu a primeira reformulação.

A lei 9.074/95 que tratou das concessões e permissões de serviços públicos e o decreto 2003/96 que regulamentou a produção de energia elétrica por produtor independente e autoprodutor, promoveram uma série de transformações no setor de geração de energia elétrica.

O novo arranjo permitiu que outros agentes econômicos pudessem participar do incremento do parque gerador de energia elétrica o que tem permitido que investidores e empresas privadas possam, por determinação do Estado brasileiro, ou seja, a partir de uma concessão, construir usinas geradoras de energia elétrica, térmica ou hídrica.

A abertura ocorrida durante o governo do presidente Fernando Henrique Cardoso trouxe a possibilidade de o capital privado investir na geração, mas não conseguiu evitar o apagão de 2001, quando toda a sociedade foi compulsoriamente levada a diminuir o consumo de energia.

Alguns motivos concorreram para que houvesse o racionamento elétrico, e um deles foi o fato de que muitos dos empreendimentos licitados e concedidos ou não obtiveram a licença ambiental ou demoraram a obtê-la, prejudicando a disponibilidade de energia no sistema que não adicionou novos MW na rede como planejado ${ }^{1}$.

\footnotetext{
${ }^{1}$ Em entrevista ao Caderno Setorial Energia do jornal Valor Econômico, a então ministra das Minas e Energia, Dilma Roussef, afirmou que em 2004 havia 45 hidrelétricas já licitadas pelo governo FHC e que tinham problemas ambientais. Destas, 24 tinham sérios problemas.
} 
Em 2004, o governo brasileiro, dessa vez, sob a gestão do presidente Lula, promoveu novas mudanças no setor elétrico do país. As leis 10.847/2004 e 10.848/2004 trouxeram duas novas situações que tiveram incidência direta sobre o licenciamento de empreendimentos hidrelétricos:

1. Criação da Empresa de Pesquisa Energética, EPE, incumbida pela lei 10.847 de fazer estudos e pesquisas destinadas a subsidiar o planejamento do setor energético. Cabe a EPE a realização da Avaliação Ambiental Integrada do conjunto dos empreendimentos hidrelétricos previstos para as bacias hidrográficas;

2. Os empreendimentos hidrelétricos só poderão ir a leilão depois de obtida a Licença Prévia - LP, a primeira de um conjunto de 3 licenças ambientais necessárias à instalação e operação de empreendimentos hidrelétricos.

O IBAMA promoveu uma série de iniciativas destinadas a melhorar a performance do sistema de licenciamento ambiental. Algumas foram paradigmáticas como a realização de concurso público para contratação de quadro estável de analistas ambientais ${ }^{2}$, a criação de áreas de licenciamento por tipologia de empreendimento e a criação do Sistema Informatizado de Licenciamento Ambiental Federal.

Em que pese os esforços de aperfeiçoamento do sistema de gestão ambiental e das tentativas de aperfeiçoar sua interface com o sistema de geração hidrelétrica, o licenciamento ambiental continua a ser interpretado como entrave à expansão do parque de geração hidrelétrica.

As mudanças na legislação do setor elétrico, o apagão ocorrido em 2001 e a crescente demanda por novos MW no sistema elétrico tem levado os setores industriais energo- intensivos ${ }^{3}$ a participar da expansão do parque de geração de energia.

Os setores de mineração, metalurgia, celulose, alumínio e outros eletro-intensivos têm investido na construção de hidrelétricas como parte da estratégia produtiva. A construção destes empreendimentos de geração de energia é necessária, uma vez que à medida que o país cresce, o setor produtivo demanda mais energia.

\footnotetext{
${ }^{2}$ Até o ano de 2002 havia apenas 8 analistas técnicos concursados e outros 70 com contratos temporários.

${ }^{3}$ São considerados energo-intensivos os setores industriais que dependem de muita energia no seu processo produtivo - alumínio, cimento, celulose, mineração, etc.
} 
No Plano Decenal de Energia 2008-2017, a EPE trabalha com a Elasticidade Renda ${ }^{4}$ de 1,1\%, ou seja, para cada ponto percentual de crescimento do PIB, é necessário incrementar o sistema elétrico $10 \%$ a mais do que o crescimento verificado no produto interno bruto.

De acordo com o estudo do Banco Mundial publicado em março de 2008 sobre o licenciamento ambiental de hidrelétricas no Brasil, as hidrelétricas respondem por $85 \%$ da matriz elétrica brasileira. O potencial hidrelétrico brasileiro é estimado em $260 \mathrm{GW}$, do qual apenas $30 \%$ estão em operação ou construção.

Nos próximos anos, do ponto de vista estritamente econômico, a região Norte tem o aproveitamento de geração hídrica mais competitivo.

Neste cenário de grande potencial hidrelétrico do país, demanda crescente por energia, fortalecimento e consolidação da legislação e do sistema de gestão ambiental, participação de novos atores econômicos interessados em prover a expansão do parque de geração de energia, assim como a maior participação dos movimentos sociais na esfera pública e uma memória não muito distante de graves problemas socioambientais ocasionados pela construção de hidrelétricas, é que se dão os conflitos socioambientais que perpassam todo o processo de licenciamento ambiental de UHE's e do qual se ocupa essa dissertação.

Entre os anos de 2004 e 2008, muitos atores econômicos e sociais envolvidos com a temática do licenciamento ambiental no país se posicionaram publicamente, sobretudo a respeito dos conflitos relacionados à concessão das licenças ambientais para empreendimentos hidrelétricos.

Do ponto de vista deste estudo, o posicionamento dos diversos atores sociais contribui para que a sociedade brasileira possa refletir sobre os caminhos do licenciamento de maneira mais plural, livre de um enfoque maniqueísta que tem prevalecido em muitas reflexões e debates sobre essa temática.

A reflexão sociológica a qual se propôs o projeto de pesquisa utilizou como recurso metodológico a revisão bibliográfica da literatura sobre licenciamento ambiental no país e da "Teoria da Modernização Ecológica", arcabouço teórico desta dissertação. Foram feitas coleta e análise dos documentos pro-

\footnotetext{
${ }^{4}$ Elasticidade-renda é a relação entre o crescimento do consumo de energia elétrica e o crescimento da economia.
} 
duzidos pelos principais atores sociais, econômicos, políticos e governamentais a respeito do licenciamento ambiental de hidrelétricas no Brasil e o acompanhamento de um estudo de caso.

Para a presente pesquisa utilizamos inúmeros documentos publicados e discutidos publicamente por um ou mais ator social envolvido com o licenciamento de UHE's brasileiras. Também entrevistamos agentes públicos, empresariais e militantes sociais envolvidos com o debate ao qual este texto se propõe apresentar uma reflexão.

Buscamos na revisão da literatura acadêmica tomar conhecimento do que já havia sido produzido sobre conflitos socioambientais originados em função da instalação de empreendimentos hidrelétricos.

Para facilitar a reflexão sobre o objeto da pesquisa acompanhamos um dos mais emblemáticos processos de licenciamento ambiental de hidrelétricas em andamento no país, Tijuco Alto. Este processo já dura 20 anos e é bastante representativo do cenário no qual emerge os conflitos socioambientais que descrevemos anteriormente.

O acompanhamento do estudo de caso foi feito através da produção acadêmica e informativa sobre o licenciamento do empreendimento em questão; a consulta aos XXI volumes ${ }^{5}$ do processo de licenciamento no IBAMA sede no mês de abril de 2008 e participação do ciclo de audiências públicas realizado em julho de 2007, além de entrevistas com parte dos atores envolvidos no processo de licenciamento. Alguns identificados a partir das audiências públicas.

A gravação de todas as audiências permitiu que depois de realizadas, assistí-las, assim como realizar a decupagem de todas as falas do ciclo de debates a respeito da UHE Tijuco Alto.

Cada uma das falas dos participantes das 5 plenárias foi analisada mediante 13 perguntas que alimentaram um banco de dados. A análise estatística das intervenções ocorridas durante as plenárias foi feita com a ajuda do software SPSS. A decupagem das audiências constatou que a participação da sociedade civil organizada seja nas perguntas ou nos posicionamentos manifestos focou principalmente em assuntos relacionados às características socioambientais do Estudo de Impacto Ambiental e do arranjo técnico do empreendimento proposto pelo empreendedor.

${ }^{5} \mathrm{O}$ processo de licenciamento não se encerrou. Provavelmente ao seu término terá mais do que os volumes que totalizavam o processo em abril de 2008. 
O fio condutor de toda a reflexão foi a Teoria da Modernização Ecológica - ME, um instrumental que teve origem no início da década de 80 nos Países Baixos, na Europa e que propõe um enfoque diferente para a reflexão e solução dos conflitos socioambientais em torno do debate, sistema produtivo $\mathrm{x}$ meio ambiente.

A Teoria da Modernização Ecológica se orienta por premissas que na prática estabelecem um paradigma diferente do que até então prevalecia na discussão sobre as relações entre ambiente e sociedade.

A ME entende que o avanço do conhecimento científico, a divisão do trabalho, a globalização, e novos padrões de mudança tecnológica na indústria e no consumo, em lugar de ser a principal responsável da degradação ambiental, podem ser fontes das soluções para os problemas ambientais (Guivant, 2005).

A dissertação, além dessa breve introdução, tem 5 capítulos e uma conclusão.

No primeiro capítulo, apresentamos e discutimos a Teoria da Modernização Ecológica, a partir do histórico das discussões ambientais e da formação da Sociologia ambiental enquanto disciplina.

O segundo capítulo faz uma discussão do estado da arte do licenciamento dos empreendimentos hidrelétricos no Brasil. Neste capítulo são apresentadas as falas e posições dos diversos atores sociais, econômicos e político administrativos referentes ao licenciamento de empreendimentos de infra-estrutura, sobretudo hidrelétricas.

Nos últimos quatro anos, governo, sociedade civil e empreendedores produziram estudos e ou participaram de discussões multissetoriais a fim de discutir aspectos relacionados ao licenciamento ambiental na perspectiva da busca de soluções capazes de fazer destravar a agenda da infra-estrutura, o que incide na necessidade de aumento do parque de geração hidrelétrica, em especial.

Buscamos os documentos produzidos no âmbito dessas iniciativas, tanto os estudos, quanto a memória das agendas multissetoriais e construímos uma narrativa a respeito do estado da arte do licenciamento ambiental e da construção de hidrelétricas no Brasil.

O terceiro capítulo faz uma reflexão crítica do licenciamento ambiental no Brasil à luz da modernização ecológica. Não há, a priori, definição precisa do que é um empreendimento licenciável, e na prática, a 
definição do que é passivo de ser licenciado é fruto de um processo político de tomada de decisão técnica. A inexistência de definição sobre este procedimento, anterior ao processo político de análise técnica de toda complexidade socioambiental que envolve uma hidrelétrica, por exemplo, cria a necessidade de que se construam acordos entre os diversos atores envolvidos nos processos de licenciamento ambiental.

A expectativa de amplos acordos em torno das características mínimas que determinado empreendimento deva ter ou não deva ter é pequena. O diálogo sistêmico não é orientado ao consenso e muito menos cooperativo. Ao contrário, o licenciamento ambiental de empreendimentos hidrelétricos tem se constituído em palco de disputa.

A participação do movimento social em inúmeros fóruns, conselhos e comissões, muitos com caráter deliberativo; criou uma cultura de participação política em setores da sociedade que historicamente excluídos dos processos de tomada de decisão, hoje entendem que a defesa de seus direitos passa pela possibilidade concreta de participar da formulação e definição das políticas públicas.

Nesse sentido, a legislação ambiental ao prever a participação social só no momento das audiências públicas, de certa forma, revela-se anacrônica, pois as principais definições a respeito do projeto já estão tomadas nessa fase do processo de licenciamento.

Essa situação alimenta a tensão e a desconfiança daqueles que terão suas vidas interferidas por um processo de tomada de decisão no qual percebem que quando são chamados a opinar, pouco há o que se modificar em relação ao projeto e nada há ainda de concreto sobre as medidas mitigadoras e compensatórias.

O quarto capítulo apresenta o licenciamento ambiental do aproveitamento hidrelétrico Tijuco Alto. Um processo emblemático por uma série de motivos: localização, características socioambientais da região onde se pretende construir o empreendimento, tempo do licenciamento e fins aos quais servirá a energia que será produzida pela UHE caso seja licenciada.

O licenciamento ambiental da hidrelétrica Tijuco Alto, foi iniciado em 1989, e após 20 anos ainda não há definição a respeito da concessão ou não da licença ambiental para o empreendimento. 
O empreendimento planejado para ser construído na divisa entre os Estados do Paraná e São Paulo tem forte oposição de setores do movimento social e ambientalista dentro e fora da região onde a Companhia Brasileira de Alumínio - CBA, uma empresa do Grupo Votorantim, pretende construí-la.

O Vale do Ribeira é uma espécie de reserva ambiental. Cerca de $68 \%$ de seu território é coberto por MataAtlântica primária. Na região vivem mais de 500 comunidades tradicionais - indígenas, quilombolas, ribeirinhos, caiçaras e caipiras que totalizam aproximadamente $35 \%$ de toda população do Vale.

As peculiaridades da região e a proximidade com o maior centro urbano do país, tem permitido que a rede local de oposição ao empreendimento consiga continuamente mobilizar apoio político, conhecimento e recursos financeiros para investimentos em projetos sustentáveis destinados a apresentar um modelo de desenvolvimento para o Vale do Ribeira alternativo ao proposto pela CBA.

O enfrentamento ao projeto de construção da UHE Tijuco Alto tem alimentado e oxigenado parcelas do movimento social local e ajudado que grupos e instituições se articulem para fora da região; como ocorre nas inúmeras parcerias feitas entre organismos públicos e ONG’s como o Instituto Sócio Ambiental ou SOS Mata Atlântica com os grupos sociais organizados.

A eletricidade é um insumo central do processo produtivo do alumínio, por esse motivo, ao dispor de MW gerados em uma hidrelétrica própria, a CBA, que tem como estratégia produzir $60 \%$ da energia que consome, garante menor custo a seu processo produtivo e, principalmente, garante o suprimento.

A licença requerida em 1989 pela indústria de alumínio para construir a hidrelétrica, depois de longo processo, foi indeferida em 2003. Um ano depois, foi reaberto o licenciamento para o qual foi emitido outro Termo de Referência e feito novo Estudo de Impacto Ambiental, que já foi apresentado e discutido em um ciclo de 5 Audiências Públicas.

No atual projeto em licenciamento houve algumas mudanças paradigmáticas em relação ao anterior, tanto do ponto de vista do arranjo técnico ambiental, quanto do trato das questões socioambientais. Estas indicam a revisão da lógica que orientou o projeto anterior e a busca da CBA em atender demandas apresentadas pelo movimento social no decorrer dos anos pelos quais se desenrola o processo de licenciamento de Tijuco Alto e da pauta nacional do Movimento dos Atingidos por Barragens - MAB. 
O quinto capítulo apresenta a síntese etnográfica do ciclo de audiências públicas a fim de subsidiar a discussão a respeito das condições concretas de diálogo entre os diversos atores sociais, econômicos e políticos envolvidos com o licenciamento ambiental.

Por ser a audiência pública o único momento previsto processualmente no qual os diversos atores podem se colocar e debater o empreendimento em toda sua complexidade, consideramos instrutivo para nossa discussão a percepção dos diversos discursos trazidos ao debate.

Nas audiências públicas da hidrelétrica Tijuco Alto, prevaleceu o debate a respeito das características técnicas do empreendimento proposto e dos impactos socioambientais que ocorrerão caso seja concedida a licença e o empreendimento construído. A contrariedade ao projeto manifestou-se a partir de perguntas e posicionamentos sobre as condições concretas do empreendimento, do questionamento a respeito da qualidade dos estudos apresentados, e da reivindicação de que fossem melhor explicitados os programas mitigatórios. Houve ainda um conjunto de posicionamentos e perguntas que chamaram a atenção para os prejuízos causados pela expectativa do empreendimento.

A observação das plenárias, necessárias à tomada de decisão a respeito da UHE, expôs a dificuldade sistêmica de formação de um acordo em torno do licenciamento de empreendimentos hidrelétricos.

Sobretudo porque o debate é quase que um jogo de cartas marcadas, onde os participantes duelam em torno de questões que vão se repetindo a exaustão em forma de perguntas e respostas com alto grau de previsibilidade e sem que as partes envolvidas demonstrem possibilidade de estar sendo convencida.

O resultado prático disso foi que nas cinco audiências, após a segunda hora do evento, às vezes sem que tivesse começado o debate, após a apresentação do EIA, as plenárias começavam a se esvaziar. Ao seu término, menos de $10 \%$ do público presente no início dos trabalhos se fazia presente. Um claro sinal dos limites das audiências públicas tal como realizadas atualmente, em que pese a importância e pertinência desse instrumento.

Na conclusão reforçamos os pontos que consideramos convergentes entre a Teoria da Modernização Ecológica e o licenciamento ambiental brasileiro. Chamamos a atenção particularmente para a conver- 
gência entre o estágio atual do licenciamento no Brasil e as três primeiras heurísticas: a) mudança das funções da ciência e tecnologia na reforma e deterioração ambiental; b) aumento da importância das dinâmicas de mercado e agentes econômicos; c) transformações nas funções do Estado-Nação.

A pesquisa constatou que a maneira como o Estado brasileiro, a partir do ano de 2004, tem buscado solucionar os problemas do sistema de licenciamento ambiental do país se insere na lógica da Modernização Ecológica.

No entanto, as heurísticas que tratam de mudanças culturais no agir sistêmico dos diversos atores, ainda não encontraram correspondência no sistema de licenciamento brasileiro.

Concluímos nossa reflexão com a apresentação de propostas que acreditamos serem capazes de promover mudanças no rito do licenciamento, provocar mudanças no agir sistêmico, e criar uma nova cultura orientada pelo debate em busca do consenso, na contra mão do clima de embate que predomina no país. 


\section{MODERNIZAÇÃO ECOLÓGICA EM PERSPECTIVA: DISCURSO OU TEORIA?}

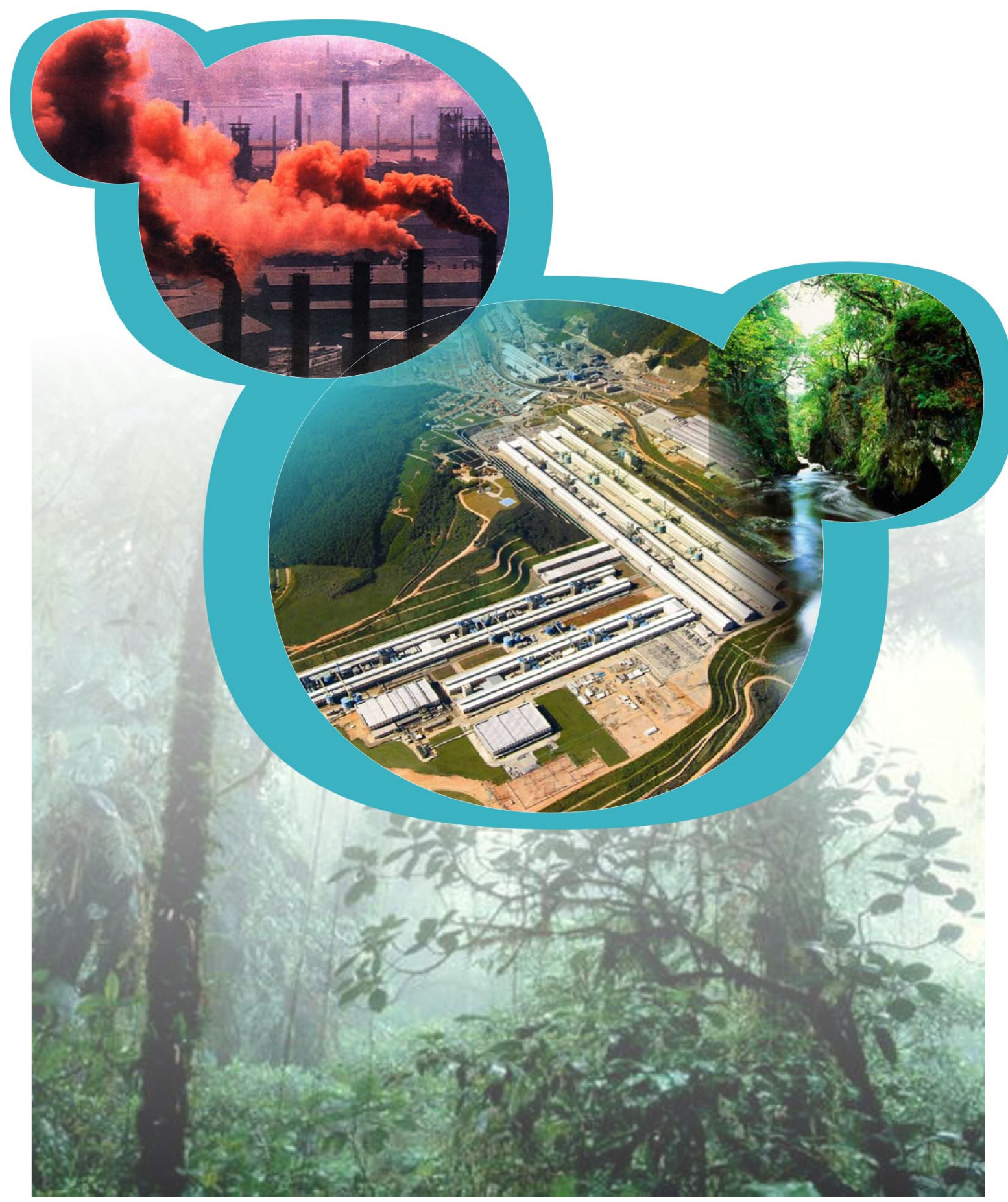




\section{Modernização Ecológica em Perspectiva}

\subsection{PRIMEIRO CENÁRIO - O DEBATE AMBIENTAL E A MODERNIDADE}

A partir do final dos anos 60, o debate ambiental foi tomado por novos problemas que emergiram associados à modernidade - poluição industrial, radiação atômica, expansão urbana e crescente percepção da escassez dos recursos naturais. Os novos temas do debate ambiental, que até então estivera circunscrito às questões de conservação da natureza, trouxeram consigo uma ampla reflexão a respeito da relação entre ambiente e sociedade e do lugar do homem.

As discussões se deram tanto na perspectiva das responsabilidades do homem em relação aos problemas concretos que se colocavam - a crise ambiental, quanto na relação com os recursos naturais, sua finitude e o debate a cerca da legitimidade das necessidades humanas frente o direito de toda a natureza.

Com o advento da cultura de massa, essas questões ganharam a arena pública rapidamente. Pressionados por um padrão de contestação que acreditava haver uma contradição estrutural entre meio ambiente e desenvolvimento, muitos países industrializados estabeleceram agências ou departamentos governamentais para lidar com as questões relativas ao meio ambiente.

Temas como proteção ambiental, educação ambiental, pesquisa ambiental, e desenvolvimento tecnológico foram organizados em novas formas institucionais, assim como, foram criadas legislações ambientais para dar respostas se não a todas, mas para algumas das questões colocadas. Este também foi o período no qual os ambientalistas, em muitos países, formaram uma identidade coletiva mais explícita e a mobilização em torno do debate ambiental tomou a forma de movimento ambiental (Jamison, 1996, pg. 229).

A idéia central do ambientalismo nos anos 70 foi a necessidade em reorganizar a ordem social em busca de uma sociedade ecologicamente saudável. No entanto, a demanda por uma ecologia inspirada para uma transformação social radical repercutiu somente marginalmente nos planos institucionais da sociedade industrial. 
As estruturas produtivas responsáveis pelo processo de degradação ambiental nos países industrializados - Japão, USA, Alemanha, Reino Unido e Países Baixos não se alteraram. O resultado prático do debate e da movimentação social, política e científica dessa época, foi a criação de departamentos de governo para o meio ambiente na maioria das sociedades industriais, expansão da legislação e planejamento ambiental, um crescente número de tratados e organizações ambientais internacionais, e um rápido aumento no número de membros de organizações ambientais não-governamentais (MOL, 2001).

A emergência dos novos temas, o processo de tomada de consciência de um conjunto cada vez mais amplo de pessoas a respeito dos problemas ambientais, a criação e o fortalecimento público da figura política do ambientalista, assim como a pressão exercida sobre as autoridades públicas e as respostas governamentais a todo esse processo, se constituiu em um movimento cíclico.

Este se estendeu e se fortaleceu em todas aquelas frentes, e alimentou-se de três forças que geraram o conhecimento, garantiram o fluxo contínuo desse conhecimento gerado e buscaram transformar toda a discussão social em soluções concretas para os problemas: a academia, as organizações não governamentais e a tecnocracia ambiental.

À medida que o debate sobre a crise ambiental deixou de ser apenas de interesse de uma parcela da intelectualidade e ganhou amplitude e consistência nas agendas dos governos nacionais, dos organismos multilaterais como ONU, Banco Mundial, OECD, inclusive com a realização da Conferência Mundial sobre Meio Ambiente em 1972, a produção do relatório Brundtland e a ECO92, paralelamente surgiu a demanda por um profissional específico, até então inexistente: o profissional ambiental.

Centros de pesquisas nas universidades e de organismos nacionais; como o World Resources Institute - WRI nos EUA, passaram a demandar profissionais com perfil acadêmico que pudessem desenvolver conhecimento a ser apropriado pelos diversos atores do debate ambiental e que pudessem ser referência no processo de tomada de decisão das soluções aos problemas em discussão.

O movimento ambientalista ganhou força e passou a ser interlocutor junto aos organismos pú- 
blicos na busca das soluções necessárias à crise ambiental por um lado, e, por outro, desempenhou a importante função de alimentar a sociedade com o conhecimento produzido dentro dos círculos acadêmicos.

Instituições como o Greenpeace e WWF transformaram o ativismo ambiental em atividade profissional, com escala e alcance planetário, pautados por ações publicitárias orientadas para os meios de comunicação de massa e administradas por padrões corporativos com o financiamento, gestão e a articulação de suas mensagens nas mãos de publicitários profissionais, consultores de gestão e experts em política (JAMISON, 1996).

A resposta dos governos aos problemas ambientais foi a criação de organismos encarregados de fazer a gestão dos temas relacionados às questões ambientais, o que acabou por estimular um corpo técnico burocrático com vocação ambiental, muitas vezes isolado no interior dos próprios governos.

\subsubsection{Do Paradigma da Excepcionalidade Humana à Ecologia como Novo Paradigma - O Campo da Sociologia Ambiental}

O debate sobre a constituição da Sociologia Ambiental enquanto disciplina própria da Sociologia encontrou nos autores americanos Catton e Dunlap, dois de seus principais precursores. No final dos anos 70, dois artigos publicados pelos autores foram críticos em relação à Sociologia, ao afirmar que tanto a sociologia clássica, quanto a contemporânea compartilhariam um forte antropocentrismo como denominador comum que as impediria de considerar a problemática ambiental (LENZI, 2006).

Embora reconhecessem que as questões relacionadas à Sociologia Ambiental têm origem em estudos e abordagens tradicionais da Sociologia, Catton e Dunlap apontaram a ausência de preocupação com a base ecológica da sociedade pela Sociologia Clássica.

No artigo publicado em 1978, intitulado “Environmental sociology: a new paradigm”, os autores trouxeram contribuição que marcou o debate sobre a emergência da Sociologia Ambiental ao apresentarem o binômio HEP-NEP, no qual HEP ou Human Exceptionalism Paradigm seria o conjunto de pressupostos que teriam orientado a produção da Sociologia até então, e NEP ou "New Environmental Paradigm", os pressupostos que propunham, deveriam orientar a Sociologia Ambiental. 


\begin{tabular}{|c|c|}
\hline \multicolumn{2}{|c|}{ Quadro 01 - Comparativo dos Pressupostos HEP X NEP } \\
\hline $\begin{array}{l}\text { Pressupostos do HEP - Human } \\
\text { Exceptionalism Paradigm }\end{array}$ & $\begin{array}{l}\text { Pressupostos do NEP - New } \\
\text { Environmental Paradigm }\end{array}$ \\
\hline $\begin{array}{l}1 \text { - Seres Humanos são únicos entre } \\
\text { as criaturas da terra devido a sua } \\
\text { cultura. }\end{array}$ & $\begin{array}{l}1 \text { - Seres Humanos são apenas uma espécie } \\
\text { entre muitas outras, envolvidas na } \\
\text { comunidade biótica que modela a vida na } \\
\text { terra de forma interdependente. }\end{array}$ \\
\hline $\begin{array}{l}2 \text { - A cultura pode variar } \\
\text { indefinidamente e pode mudar } \\
\text { mais rapidamente que os traços } \\
\text { biológicos. }\end{array}$ & $\begin{array}{l}2 \text { - Ligações intrincadas de causa e efeito e } \\
\text { feedback na rede da natureza produzem } \\
\text { conseqüências não intencionadas da ação } \\
\text { humana intencional. }\end{array}$ \\
\hline $\begin{array}{l}3 \text { - Muitas diferenças são } \\
\text { socialmente induzidas antes do que } \\
\text { congênitas, elas podem ser } \\
\text { socialmente alteradas quando } \\
\text { vistas como incovenientes. }\end{array}$ & $\begin{array}{l}3 \text { - O Mundo é finito, assim há limites físicos } \\
\text { e biológicos potenciais constrangendo o } \\
\text { crescimento econômico, o progresso social } \\
\text { e outros fenômenos societais. }\end{array}$ \\
\hline $\begin{array}{l}4 \text { - A acumulação cultural significa } \\
\text { que o progresso pode continuar } \\
\text { sem limites, tornando todos os } \\
\text { problemas solucionáveis. }\end{array}$ & \\
\hline
\end{tabular}

Fonte: Lenzi, 2006

Em 1979, ao publicarem o segundo artigo, intitulado "Environmental sociology”, propõem a distinção entre Sociologia das questões ambientais e a Sociologia Ambiental. A primeira incorporaria somente de forma marginal, a temática ambiental e teria a Sociologia "Tradicional" como referência do instrumental reflexivo e a segunda traria a questão ecológica como elemento estruturante da sua reflexão.

De acordo com Lenzi, na formulação dos pressupostos do NEP, Catton e Dunlap se utilizaram de referências discursivas originárias de fora do campo da sociologia, porém presentes na literatura social originária do movimento ambientalista. O pressuposto $\mathrm{n}^{\circ} 1$ do NEP afirma que o ser humano é mais uma das espécies dentre muitas outras em situação de interdependência, princípio esse que se diferencia muito pouco dos pilares da ecologia profunda sobre a igualdade biocêntrica.

O pressuposto $\mathrm{n}^{\mathrm{o}} 3$ que diz respeito à finitude dos recursos físicos e biológicos remonta aos escritos do economista Thomas Malthus no século XVIII; e mais recentemente, na década de 70, dois livros que fizeram sucesso entre ambientalistas tinham estrutura argumentativa semelhante: "The limits to growth" que discutiu a contradição eminente entre o crescimento econômico e aumento da população por um lado e a capacidade de provimento desse crescimento por parte dos recursos do planeta, e "Population Bomb", livro escrito por Ehrlich que também discutia o crescimento populacional e a capacidade do planeta prover a todos. 
Em artigo intitulado "Classical Theory and Contemporary Enviromental Sociology: some reflections on the antecedents and prospects for reflexive modernization theories in the study of environment and society”, Frederick Buttel questiona algumas das premissas apresentadas por Catton e Dunlap, principalmente a tese cara aos dois americanos, que enfatiza o descolamento entre a tradição clássica da Sociologia e a Sociologia Ambiental.

Buttel defende o ponto de vista de que a Sociologia Ambiental está permeada pela influência de Marx, Durkheim e Weber. Sobre Marx diz que "há freqüentemente uma crítica ritualística do Marxismo por seu descaso com o meio ambiente, o neo-Marxismo é talvez a influência mais penetrante na sociologia ambiental no mundo todo hoje" (BUTTEL, 2000, pg.23).

Em relação a Durkheim; Buttel afirmou que o sociólogo francês havia utilizado livremente conceitos biológicos ao apresentar suas teorias da solidariedade e evolução social, como está evidente no conceito de solidariedade orgânica. Além disso, seu trabalho mais famoso, The Division of Labor in Society (1893), descreveu os elementos principais de uma perspectiva teórica que veio a ser conhecida como ecologia humana.

O esquema teórico da divisão social do trabalho, que explica a transição da solidariedade mecânica para a orgânica, era rico no imaginário sobre a densidade populacional, escassez de recursos, e competição para sobreviver e tem uma forte semelhança com os conceitos mais modernos de ecologia humana, inclusive o conceito de complexo ecológico proposto por Catton e Dunlap (BUTTEL, 2000, pg.21).

Sobre Max Weber, escreveu que reconhecidamente foi a primeira ruptura decisiva do evolucionismo do século XIX, ancorado nas analogias biológicas, uma vez que rejeitava o ponto de vista teórico de que havia um curso unilinear do desenvolvimento social e que a mudança social era fruto das mudanças das forças tecnológicas, estruturais e subjetivas enraizadas na história e motivadas pela ação humana.

No entanto, o autor americano chamou atenção para o fato de que os trabalhos de Max Weber que mais claramente refletem a sua ruptura com as análises biológicas são "The Agrarian Sociology of Ancient Civilizations" e "General Economic History"; em cujo material sobre os impactos das estruturas sociais nos recursos naturais ou o impacto dos recursos naturais nas organizações sociais é proeminente"(BUTTEL, 2000, pgs. 21e 22). 
Buttel considera a sociologia ambiental norteamericana dos anos 70 e 80 como tendo sido um necessário, mas incompleto, passo no desenvolvimento do pensamento sobre as relações sócio-ambientais. As contribuições dos sociólogos norte-americanos deveriam ser consideradas como ponto de partida, mais do que como ponto final.

O sociólogo inglês apontou duas limitações da literatura ambiental tradicional norte americana:

1. Deu muito mais atenção a teorizar a degradação ambiental do que a melhoria ambiental;

2. Superestimou a coerência dos movimentos ambientais, e exagerou na crença segundo a qual a melhora ambiental derivaria da mobilização dos movimentos ambientais, uma vez que a legislação ambiental americana é do início dos anos 70 e pouco avançou depois disso, mesmo com o crescimento do movimento ambientalista no país.

\subsection{SEGUNDO CENÁRIO -A EMINÊNCIA DE UMA TEORIAAMBIENTAL GLOBAL}

Depois do fracasso ocorrido nos anos 70 no combate aos problemas ambientais, diagnosticados como consequiência do padrão de produção industrial e do modelo de desenvolvimento em curso, no final dos anos 80, houve a retomada do enfrentamento destas questões em um patamar completamente diferente do vivenciado no fim da década de 60.

No decurso dos 20 anos que separaram a segunda e terceira fases do debate ambiental ${ }^{6}$, e da busca de soluções para os problemas ambientais, todos os atores que emergiram nos debates ocorridos dos anos 70 se fortaleceram individualmente e a própria sociedade com seus inúmeros agentes em constante interação criou acúmulos coletivos e individualizados, em algumas situações acúmulos sinérgicos que acabaram por criar as condições para o salto ocorrido na última década do século XX:

\footnotetext{
${ }^{6}$ As diferentes fases do debate e enfrentamento dos problemas ambientais têm recortes semelhantes na literatura, até os anos 80 quando há a emergência das discussões sobre a mudança ambiental global. Neste estudo, iremos utilizar três períodos: Primeira fase - até os anos 60, quando prevaleceu uma abordagem ambiental conservacionista. Segunda fase - virada dos anos 60, para os anos 70 quando a percepção dos problemas causados pelo processo de industrialização impulsionou o debate marcado pela oposição entre crescimento e meio ambiente. Terceira fase - A partir do final dos anos 80, quando, frente o fracasso experimentado na década de 70 no enfrentamento da crise ambiental, pautado pela oposição entre crescimento e meio ambiente, a discussão passa a ser feita em torno das mudanças ambientais globais.
} 
1. A intelligentsia ambiental consolidou-se nas mais diversas áreas, inclusive no campo da Sociologia ${ }^{7}$ - Uma variedade de disciplinas debruçou-se sobre a reflexão e produção de conhecimento técnico e científico voltado às questões ambientais: economia, engenharia, antropologia, pedagogia, administração, marketing, arquitetura e em muitas delas com subdivisões internas às próprias disciplinas que em alguns casos se fragmentaram para cuidar de aspectos específicos da interface disciplina/meio ambiente;

2. O movimento ambientalista multiplicou-se e tornou-se interlocutor freqüente para os mais variados temas da agenda ambiental, e junto às mais diversas instituições, fóruns e instâncias de poder. Uma multiplicidade de ONGs ambientalistas foram criadas com alcance de atuação diverso (local, regional, global), além de escopo de atuação diferenciado (recursos hídricos, proteção da floresta, proteção dos povos da floresta, contra barragens, proteção ambiental, em defesa do Planeta, etc). O padrão de profissionalização alcançado já por algumas ONGs na década de 70 foi seguido, e o conceito de sustentabilidade (emprestado das discussões ambientais) passou a ser uma das principais tarefas a serem vencidas.

3. O capital entrou no debate ambiental -Se antes era quase uma imposição motivada por aspectos legais ou pela pressão social, com o passar do tempo a incorporação das questões ambientais passou a ser diferencial de mercado e até fonte geradora de novos lucros;

4. As questões ambientais entraram definitivamente nas agendas dos Estados nacionais e no organograma administrativo;

5. As legislações aperfeiçoaram-se ou estabilizaram-se como parte do arcabouço jurídico, produzindo os efeitos de longo prazo que se espera da aplicação continuada da lei;

6. Os organismos multilaterais deram maior legitimidade ao debate em escala globalRelatório Nosso Futuro Comum, ECO - 92, e criaram políticas próprias relacionadas à temática ambiental, seja na criação de programas próprios como o IPCC ou no estabelecimento de critérios ambientais para o financiamento de projetos e programas. 
As transformações ocorridas em torno das relações entre sociedade e meio ambiente, a adesão de amplos setores sociais ao debate ambiental e o processo de globalização econômica impulsionaram uma mudança paradigmática no debate ambiental que trocou o eixo da discussão dos "limites ao crescimento" para "mudança global". A atenção dispensada aos problemas ambientais de dimensões globais e a reestruturação dos problemas ambientais quanto à transformação global foram característicos da terceira onda da preocupação ambiental.

Esta foi uma idéia trazida às agendas e políticas públicas pela primeira vez pela Comissão Brundtland. A partir do final dos anos 80 , as agendas ambientais da comunidade internacional pareceram cada vez mais dominadas por problemas relacionados aos chamados problemas comuns globais, tais como o efeito estufa, destruição da camada de ozônio, diminuição da biodiversidade, rápido desaparecimento das florestas tropicais e poluição dos oceanos (MOL, 2001, pg.54).

A mudança do paradigma provocou mudanças na forma como as relações entre ambientalistas, Estado e capital passaram a se relacionar. Sob a perspectiva da mudança ambiental global sai o ideário de enfrentamento e idéias como interdependência e cooperação passam a orientar a ação política e institucional de ONGs, empresas, governos e agências.

O padrão de relacionamento das fases anteriores - quando os ambientalistas responsabilizavam as corporações pela poluição e degradação ambiental - passou a ser visto por muitas ONGs e empresários como anacrônicas. Agora, corporações e ambientalistas são convidados a colaborar no desenvolvimento da chamada sociedade sustentável. Os problemas e soluções são redefinidos de maneira que conduzam a novas correções tecnológicas para a indústria e novas oportunidades para as organizações ambientais (JAMISON, 1996, pg. 234).

A política ambiental migra de um modelo regulador hierárquico, com o processo de tomada de decisão estatal de cima para baixo, para uma abordagem mais horizontal entre os diversos atores envolvidos e foco na agenda de consenso. O papel do Estado é redefinido a partir da maior participação da sociedade civil e do mercado no processo de tomada de decisão (LEROY \& BLOWERS, 1998).

O formato de política ambiental implica no envolvimento e participação de setores diversificados e que em outros contextos e situações não dialogavam. Estado, mercado e agentes sociais são envolvidos 
em discussões e fruto de algumas coligações passaram a partilhar funções com seus próprios objetivos e recursos. Os acordos, pactos e convênios são muitas vezes geridos e executados por órgãos governamentais, empresas e sociedade civil de maneira que todos assumem responsabilidades pela implementação efetiva das políticas ambientais.

A fim de entender a mudança global, a Sociologia Ambiental e outras ciências sociais passaram a focar na relação entre as dimensões do processo de globalização (política, sócio-cultural) por um lado; e todas as manifestações da deterioração ambiental, percepção ambiental e reforma ambiental por outro (MOL, 2001, pg.55).

\subsection{A MODERNIZAÇÃO ECOLÓGICA - ME}

As idéias da modernização ecológica surgiram relacionadas a um restrito grupo de países - Alemanha, Holanda, e Reino Unido no início dos anos 80; e inovou ao propor a reflexão sobre a crise ambiental em patamar diferente ao vivenciado na década de 70.

No cerne da abordagem sobre a complexa relação entre meio ambiente e sociedade está a crença de que não existe uma contradição insuperável entre desenvolvimento e ambiente. A partir da análise das funções desempenhadas pelas instituições da modernidade - Estado, esferas produtivas, aparato científico e tecnológico e sociedade civil, os teóricos da ME irão propor novos arranjos no interior destas instituições e no relacionamento destas entre si, capazes de dar as respostas necessárias aos problemas ambientais da modernidade.

\subsubsection{Histórico da ME}

Os primeiros escritos das idéias da ME datam de 1982 quando o sociólogo alemão Joseph Huber apresentou as bases que iriam mobilizar esse debate nos anos seguintes. Em pouco mais de 25 anos, o intenso debate do qual foi alvo a ME pressionou seus formuladores a rever e aperfeiçoar as bases constitutivas de seu instrumental analítico de modo que o cientista social Arthur $\operatorname{Mol}(2001,2003)$ divide a história da modernização ecológica em três fases. 
$1^{\mathrm{a}}$. Início dos anos 80 quando a teoria caracterizou-se por:

I. Enfatizar o papel das inovações tecnológicas junto a esfera da produção industrial;

II. Atitude mais crítica para com o Estado (burocrático);

III. Otimismo em relação aos atores de mercado às dinâmicas de mercado nas reformas ambientais (atitude apreciada por estudiosos neoliberais);

IV. Pouca ênfase na participação social e na sua capacidade de provocar mudanças;

V. Concentração nos estudos nacionais e subnacionais.

De acordo com Mol, mesmo depois de superadas muitas das deficiências do arcabouço inicial proposto nesta fase, a ME continuou a sofrer críticas relacionadas a formulações desse período.

$2^{\mathrm{a}}$. A partir do final dos anos 80 , foi marcada pela tentativa de superar as fragilidades características do primeiro momento. Os estudos publicados nesse período buscaram:

I. Relativizar a importância das inovações tecnológicas como o elemento dinamizador da modernização ecológica;

II. Estabelecer uma visão mais equilibrada do Estado e de dinâmicas de mercado no processo de transformação ecológica;

III. Dar mais peso às dinâmicas cultural e institucional e ao papel dos seres humanos no processo de transformação social.

As principais críticas feitas tanto por estudiosos da ME e também por seus críticos em relação à produção desse período foram em relação ao caráter eurocentrista da teoria, uma vez que os estudos comparativos ou nacionais da produção industrial continuaram restritos aos países da tríade - Alemanha, Inglaterra e Holanda.

Além disso, críticas apontaram definições limitadas do meio ambiente e expectativas completamente otimistas da reforma ambiental em relação às práticas sociais, desenvolvimentos institucionais e debates ambientais, por um lado e descaso por estilos de vida e práticas de consumo, por outro (MOL, 2001). 
$3^{\text {a }}$. A partir de meados da década de 90 , os estudos buscaram aprofundar a reflexão da ME em três frentes:

I. Os estudos sobre produção industrial foram complementados por trabalhos sobre transformações ecológicas relacionadas com o processo de consumo;

II. A crítica ao eurocentrismo do segundo período resultou em vários estudos nacionais sobre a reforma ambiental nos países não-europeus (países recém industrializados e economia em transição na Europa Oriental e Central, USA e Canadá), levando a um conjunto de conclusões sobre a relevância desta estrutura teórica para entender o processo de reforma ambiental;

III. Maior atenção às dinâmicas globais da modernização ecológica.

Mol conclui que embora existam diferenças temporais, teóricas e nacionais em relação às contribuições da ME, os estudos desenvolvidos por diversos autores ${ }^{8}$ podem ser reunidos sob a influência da modernização ecológica por partilharem características semelhantes em suas estruturas analíticas:

1. Os problemas ambientais são entendidos como desafios a serem superados pela reforma econômica e sócio-técnica, mais do que a conseqüência inevitável da estrutura institucional;

2. A reforma ambiental é consequiência das transformações das instituições modernas no campo das ciências e tecnologias, do Estado, das políticas globais e do mercado global.

3. Há diferenciação das abordagens utilizadas por neomarxistas, assim como das análises pós-modernistas e da contra-produtividade. Os teóricos da modernização ecológica não enxergam uma contradição estrutural entre desenvolvimento e meio ambiente.

\footnotetext{
${ }^{8}$ Mol,2003-Ver autores apontados por Mol: Joseph Huber, Martin Jänicke, Volker von Prittwitz, Udo Simonis e Klaus Zimmermann, Gert Spaargaren, Maarten Hajer e Arthur Mol, Albert Weale, Maurie Cohen, Joseph Murphy, Jokinen, Koskinen; Sairinen, Lundqvist, Harris, Andersen, Gouldson, Murphy, Lauber, Liefferink, Pellow, Rinkevicius, Gille, Frijins, Sonnenfeld, Spaargaren, Buttel, Blowers e Blühdorn.
} 
O quadro mudança de paradigma da política ambiental apresenta as diferenças de discurso da política ambiental dos anos 70 e o discurso da modernização ecológica.

\begin{tabular}{|c|c|}
\hline Quadro 02 - Mudança de Pa & igma da Política Ambiental \\
\hline Política Ambiental nos Anos 70 & O Discurso da Modernização Ecológica \\
\hline $\begin{array}{l}\text { SOMA NEGATIVA.Relação de } \\
\text { soma-zero assumida entre custos de } \\
\text { proteção ambiental e crescimento } \\
\text { econômico. }\end{array}$ & $\begin{array}{l}\text { SOMA POSITIVA. Busca por soluções de } \\
\text { soma positiva entre crescimento econômico } \\
\text { e proteção ambiental.Eficiência através da } \\
\text { redução da poluição e do desenvolvimento } \\
\text { de tecnologias de controle de poluição. }\end{array}$ \\
\hline $\begin{array}{l}\text { D E S I M P O R T ̃̃ N C I A D A } \\
\text { ECOLOGIA. Não reconhecia a } \\
\text { dependência da economia em relação } \\
\text { à s u a b a e e c o lógi i ca. E s s a } \\
\text { dependência não foi considerada } \\
\text { como uma questão significativa pelas } \\
\text { corporações e elites do estado. }\end{array}$ & $\begin{array}{l}\text { ACUMULAÇ̃̃O e LEGITIMIDADE. } \\
\text { Reconhecimento de que a manutenção do } \\
\text { meio ambiente é uma condição essencial da } \\
\text { acumulação econômica e para a } \\
\text { legitimidade do Estado. }\end{array}$ \\
\hline $\begin{array}{l}\text { CIÊNCIA. Confiança excessiva na } \\
\text { ciência. }\end{array}$ & $\begin{array}{l}\text { PRECAUÇÃO. Adoção do princípio de } \\
\text { precaução para decisões que vão para além } \\
\text { da ciência. }\end{array}$ \\
\hline $\begin{array}{l}\text { POLUIÇÃO E FRAGMENTAÇÃO } \\
\text { BUROCRÁTICA. Abordagem a } \\
\text { problemas específicos de poluição e de } \\
\text { alta visibilidade promovendo a } \\
\text { fragmentação burocrática. }\end{array}$ & $\begin{array}{l}\text { ABORDAGEM INTEGRADA. São } \\
\text { nesessárias abordagens } \\
\text { controle da poluiçâanicas ao } \\
\text { transfers). }\end{array}$ \\
\hline $\begin{array}{l}\text { IS OL A METO DECISÓRIO. } \\
\text { Isolamento do processo de tomada de } \\
\text { decisão política, tornando-se alvo de } \\
\text { pressão de um pequeno grupo de } \\
\text { instituições e da elite. }\end{array}$ & $\begin{array}{l}\text { AMPLIAÇÃO DA PARTICIPAÇÃO } \\
\text { NO PROCESSO DECISÓRIO. Esforço } \\
\text { para incluir grupos ambientais na formação } \\
\text { da política ambiental.Novo padrão de } \\
\text { corporativismo e processos de resolução de } \\
\text { disputa objetivando a administração } \\
\text { eficiente de conflitos por meio do Estado. }\end{array}$ \\
\hline $\begin{array}{l}\text { A BORD AGEM. A bordagem } \\
\text { regulatória enfatizando padrões de } \\
\text { emissão uniforme. }\end{array}$ & $\begin{array}{l}\text { INSTRUMENTO DE MERCADO. } \\
\text { Experimentação com mecanismos e } \\
\text { abordagens de mercado. }\end{array}$ \\
\hline $\begin{array}{l}\text { FALTA DE MONITORAÇ̃̃o. } \\
\text { Falta de mecanismo de avaliação e } \\
\text { monit oração das políticas } \\
\text { ambientais. }\end{array}$ & $\begin{array}{l}\text { DÉFICIT DE IMPLEMENTAÇÃO. } \\
\text { Reconhecimento do ploblema de déficit de } \\
\text { implementação }\end{array}$ \\
\hline $\begin{array}{l}\text { FOCO NACIONAL. Atenção das } \\
\text { políticas ambientais sobre o território } \\
\text { nacional. }\end{array}$ & $\begin{array}{l}\text { REGIME INTERNACIONAL. Proposta de } \\
\text { criação de regimes ambientais internacionais. } \\
\text { Emergência de novos padrões de opotunidade } \\
\text { política e restrições se ampliando nos níveis } \\
\text { regional, nacional e global. }\end{array}$ \\
\hline
\end{tabular}

Fonte: Lenzi, 2006

\subsubsection{Principais Pressupostos da Modernização Ecológica}

A modernização ecológica tem como linha estruturante de sua reflexão o fato de que as preocupações ecológicas entraram na agenda dos principais agentes da sociedade moderna e em movimento de retroalimentação avançam e se estendem sobre um leque crescente de situações e instituições. 
A modernizaçãoecológica rompeu com a perspectiva da desmodernização que dominou odiscurso ambiental até o início dos anos 80 ao propor que a solução à crise ambiental passava pela modernização das instituições da sociedade moderna. Os atores sociais assumem papel de destaque, uma vez que caberá a eles construir novos arranjos capazes de articular a racionalidade ambiental a outras racionalidades, inclusive a econômica.

O processo vivenciado a partir dos anos 70 em relação à crise ambiental avança e a ecologia ganha racionalidade e esfera próprias, descoladas das racionalidades econômica, política e sócio-ideológica.

As questões ambientais moveram-se da periferia para o centro da preocupação de um grande número de diferentes grupos sociais e organizações. Isto pode ser interpretado como um processo de institucionalização gradual das preocupações ambientais nas mídias e seu público, com diferentes níveis de administração governamental e nos círculos empresariais (SPAARGAREN, 2000).

A modernização ecológica como uma teoria da mudança social reflete neste processo de institucionalização das preocupações ambientais, pela necessidade em refinar conceitualmente os modelos existentes utilizados na ciência social para analisar os processos de modernização ou racionalização.

Em vez do modelo dicotômico - construído na oposição entre sociedade e natureza, comum nas ciências ambientais sociais, Spaargaren (2000) propõe um modelo em que 4 dimensões ou esferas são analiticamente distinguidas - esfera política, econômica, ideológico-social e esfera ambiental influenciam-se umas às outras, sem que haja redução da racionalidade de uma em detrimento de outra.

\section{Gráfico 01}

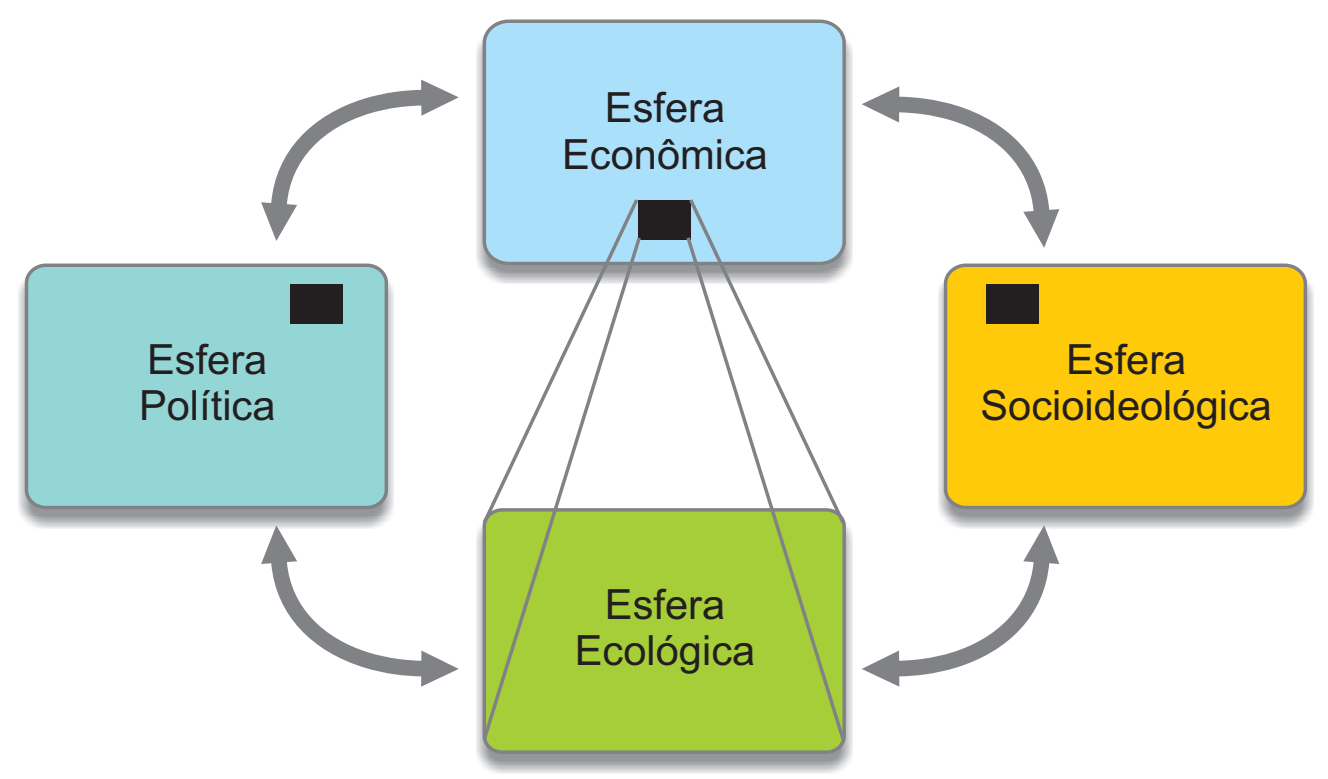

Fonte Spaargaren, 2000, pg. 54. 
Ao discutir o descolamento da esfera ecológica das demais, Mol (2001) sustenta a posição de que os processos econômicos de produção e consumo são cada vez mais analisados e julgados, assim como, planejados e organizados tanto do ponto de vista ecológico quanto econômico.

Enfatiza que sociólogos ambientais sugerem que interesses e considerações relativas ao ambiente não só orientem transformações nas sociedades industriais contemporâneas, "mas que a ecologia surgirá como o novo conceito sensibilizante pelo qual a sociedade industrial se orientará em seu desenvolvimento futuro" (MOL, 2001, pg. 60).

\subsubsection{A Modernização Ecológica em 5 pontos}

Em estudos diferentes, Mol (MOL \& SONNENFELD, 2000; MOL \& SPAARGAREN, 1998; MOL, 2001; MOL, 2003) em um esforço de sistematização tem apresentado cinco principais características da modernização ecológica:

\section{1) Mudança das funções da ciência e tecnologia na reforma e deterioração} ambiental - Há uma mudança estrutural do papel da C\&T que passam a ser identificadas como instrumentos importantes da reforma ambiental. A variável ambiental é incorporada ao processo de desenvolvimento tecnológico, inclusive sob o princípio da precaução. Arranjos tecnológicos sujos ou com potencial de degradação ambiental não são bons. A ciência e a tecnologia são valorizados por seu papel potencial e real, primeiro de prevenir e depois de reparar os problemas ambientais;

\section{2) Aumento da importância das dinâmicas de mercado e agentes econômicos -}

Maior participação de organismos financeiros e instrumentos de mercado na definição de novas práticas comprometidas com a reforma e reestruturação ecológicas produtores, consumidores, instituições de crédito, companhias de seguro, associações empresariais. Estes, cada vez mais, tornam-se condutores sociais da reestruturação ecológica, inovação e reforma, em acréscimo e não em substituição aos esforços despendidos pelas agências do estado e movimentos sociais. 
3) Transformações nas funções do Estado-nação - Em oposição a estruturas governamentais centralizadoras, gestão ambiental hierarquizada e excessiva regulação, os governos adotam padrão descentralizado, flexível e orientado para o consenso na gestão das questões ambientais. Atores sociais não estatais assumem funções na administração, regulamentação e cooperação de políticas ambientais. Instituições supranacionais emergentes passam a desempenhar funções antes exercidas pelo Estado.

4) Modificações na posição, função e ideologia dos movimentos sociais - Os movimentos sociais são cada vez mais envolvidos nos processos de tomada de decisão e ações das instituições públicas e privadas quanto às reformas ambientais. Migram de uma posição periférica no processo de tomada de decisão das políticas públicas e passam a fazer parte desses processos. Mudança significativa tendo-se em conta o posicionamento do movimento ambientalista que prevaleceu nas décadas anteriores.

5) Mudança das práticas discursivas e novas ideologias - A contraposição fundamental entre interesses ambientais e econômicos, assim como, a completa negligência da importância das considerações ambientais, não são mais aceitas como posições legítimas. A solidariedade intergeracional surge como princípio e objetivo incontestável.

Mol (2001) chama atenção para o fato de as transformações não ocorrem em todos os países estudados do mesmo modo, na mesma escala e ao mesmo tempo, e que o instrumental analítico é aplicado de diferentes modos por diferentes estudiosos. Alguns os vêem como ferramentas analíticas a serem usadas para entender a reforma ambiental. Outros os vêem também como orientações para projetar o melhor e mais eficaz modelo de reforma ambiental para o futuro.

Independentemente do grau em que estas transformações ambientais induzidas acontecerão, a conclusão da interpretação do que está acontecendo durante a terceira onda da reforma ambiental é refletida nas teorias sociais que dominam o debate ambiental atual. "Dentro da subdisciplina da Sociologia Ambiental (ou ao menos nas contribuições da Europa Ocidental) as teorias neomarxistas e 
contraprodutividade têm ficado um pouco em segundo plano enquanto modelos e idéias ao longo da linha da modernização ecológica estão em ascensão" (MOL, 2001, pg. 62).

\title{
1.3.4 Crise e Reforma Ambiental no Brasil - Qual o papel da Modernização Ecológica?
}

Uma das principais críticas à modernização ecológica tem sido em relação às suas limitações geográficas. Embora já na segunda fase tenha havido a ampliação dos países nos quais se realizaram estudos de caso, a revisão bibliográfica da produção dessa corrente do pensamento sociológico identificou limitações assumidas por Mol em relação a países emergentes fora do eixo Norte da Europa ou daAmérica Central.

\begin{abstract}
Idéias e reformas institucionais da modernização ecológica são baseadas em pressupostos específicos, que geralmente não são válidos para estas regiões em desenvolvimento: por exemplo, a existência de um welfare state com responsabilidades ambientais institucionalizadas e articuladas, desenvolvimento tecnológico avançado dentro de uma sociedade altamente industrializada, uma economia de mercado regulamentada pelo Estado cobrindo todas as partes da sociedade e estritamente conectada ao mercado mundial globalizado, e consciência ambiental institucionalizada, generalizada, relativamente profunda (MOL, 2001, pg. 64).
\end{abstract}

Ainda sobre o caráter eurocêntrico da ME, argumenta-se que as reformas ambientais ocorridas nos países industrializados só foram possíveis devido ao processo de "colonialismo ambiental”; mecanismo pelo qual os países desenvolvidos exportam para os países em desenvolvimento plantas industriais de processos produtivos mais sujos e ou que utilizam recursos naturais escassos.

Mol (2001) responderá que em uma sociedade globalizada, de fato, é difícil certas proteções ecológicas e estratégias de reforma para uma área geográfica específica, para não falar em um país. Mas sugere que países da Europa oriental e central, Ásia leste e sudoeste e América Latina poderiam pegar as iniciativas e modelos de reestruturação ecológica que lentamente emergem nos países industrializados como um ponto inicial, nem mais nem menos, dirá o sociólogo holandês.

Do ponto de vista da nossa pesquisa e da contribuição que ela se propõe a dar ao debate ambiental no país, esse parece ser um importante ponto de discussão.

Não há dúvida alguma dos limites da modernização ecológica seja como instrumental teórico seja como discurso sócio-ideológico, em relação a sua aplicabilidade ao contexto brasileiro, mas também 
não nos faltam fatos que apontem semelhanças entre o estágio atual de nossas instituições, do passado recente do movimento social e dos problemas ambientais que enfrentamos com o cenário econômico, político e social no qual tiveram origem as discussões sobre as reformas propostas pela ME.

O Brasil, embora esteja muito longe de ser um "Estado de bem estar social", é a 9a economia do mundo, tem um parque industrial grande, é uma economia de mercado regulamentada pelo Estado, além de ser um "player" importante do mercado globalizado, ainda que participe como grande produtor de commodities.

Menos importante do que investigar o estágio atual da reforma ambiental proposta pela modernização ecológica; tarefa que pode se mostrar inútil, uma vez que o país não se enquadra totalmente nas condições estabelecidas pelos teóricos da proposta, acreditamos ser mais interessante refletir de que maneira o ideário da ME pode ser útil no enfrentamento dos inúmeros problemas sócio-ambientais que o país enfrenta.

\subsubsection{Modernização Ecológica como Aprendizagem Social}

O economista Maarten Hajer (1996), ao discutir a modernização ecológica sob o viés das transformações culturais, afirma que há um consenso em torno do debate ambiental de que os processos de aprendizagem institucional e convergência social têm permitido acordos, em torno das reformas ambientais propostas pela modernização ecológica. “A suposição central deste paradigma é que as instituições dominantes na verdade podem aprender e que essa aprendizagem pode produzir mudança significativa" (HAJER, 1996,pg. 251).

A participação do movimento ambiental tem sido importante para a construção de arranjos institucionais capazes de gerar acordos pautados pela solução dos problemas ambientais, e o autor afirma que esse processo só foi possível depois que o movimento rompeu com o radicalismo que marcou seu posicionamento nos períodos que antecederam a ME.

Mas, como já descrito anteriormente nesse trabalho ${ }^{9}$, não só o movimento ambientalista reviu suas

\footnotetext{
${ }^{9}$ No item 3 desse capítulo apresentamos as bases a partir das quais a discussão ambiental ganhou fôlego, a partir dos anos 80 .
} 
posições no debate que teve origem no início dos anos 70, mas que ganhou impulso a partir da década de 80 .

Os demais atores sociais (Estado e capital) formaram massa crítica em relação aos temas da agenda ambiental. Investiram na contratação de profissionais ambientais e criaram no organograma de suas instituições departamentos vocacionados à temática do meio ambiente, ampliaram a interlocução com os setores acadêmicos e reviram seu sistema de crenças a respeito dos problemas ambientais e de como resolvê-los.

Do nosso ponto de vista; a ME pode dar novo impulso ao debate dos problemas ambientais no país ao oferecer o testemunho de que a redefinição do papel do Estado de um modelo regulador, hierárquico, com processo de tomada de decisão de cima para baixo, para uma abordagem baseada em uma relação mais 'horizontal' entre os atores envolvidos, visando uma política negociada, endossada pelo consenso entre eles; foi capaz de criar as condições de diálogo das quais emergiram condições concretas para a resolução de problemas ambientais.

Os círculos empresariais brasileiros pode se inspirar nas conquistas protagonizadas pela reforma ambiental dos países desenvolvidos, muitos deles onde estão as matrizes de empresas atuantes no país ou de grupos empresariais parceiros de empresas brasileiras e descobrir que as dificuldades em enfrentar situações aparentemente incômodas relacionadas às questões ambientais podem se constituir em perda de negócios.

Dito de outra forma, um olhar mais atento sobre os resultados protagonizados pela reforma ambiental no campo empresarial, poderá chamar a atenção para o fato de que incorporar a variável ambiente ao modelo de negócio pode ser um bom negócio.

O ambiente de diálogo constante e permanente orientado para o consenso em torno das soluções requeridas pelos problemas ambientais é em si um ganho, na medida em que criam as condições necessárias para que a atividade econômica prospere sem contestações de sua legitimidade frente ao interesse do conjunto da sociedade ${ }^{10}$.

\footnotetext{
${ }^{10}$ Sobre esse assunto é interessante notar como algumas indústrias como a Vale do Rio Doce, a Companhia Brasileira de Alumínio e outras grandes indústrias poluidoras ou que utilizam recursos naturais em abundância, em seus processos produtivos, têm investido em campanhas públicas nos grandes veículos de comunicação; a fim de melhorar sua imagem frente à sociedade brasileira, ainda que seu mercado potencial não sejam os cidadãos individualmente e sim indústrias de transformação, grande parte delas fora do país.
} 
Ao sugerir a modernização ecológica como um caminho a ser perseguido na busca das soluções para os problemas socioambientais do país não afirmamos ser a própria ME uma obra acabada, sobretudo porque, como já exposto anteriormente, será necessário a construção de referências para sua aplicação em países em desenvolvimento.

Há problemas a serem enfrentados no âmbito do instrumental já construído por seus teóricos e que precisam ser equacionados. A questão apresentada por Leroy \& Blowers (1998) sobre quais são os grupos que devem ocupar o espaço político onde se constroem os acordos é de fundamental importância no caso brasileiro uma vez que grupos socialmente excluídos têm sido os mais prejudicados pelos problemas socioambientais enfrentados no país (ACSELRAD, 2004).

Da mesma maneira que consideramos oportuna a utilização do instrumental produzido pela ME, entendemos que o sucesso da utilização do mesmo passa por um processo de adaptação, no qual sejamos capazes de reler as experiências da reforma ambiental ocorridas nos países desenvolvidos com os olhos de um país em desenvolvimento.

\subsubsection{Modernização Ecológica e o setor de infra-estrutura no Brasil}

O setor de infra-estrutura tem sido um dos que mais tem enfrentado problemas socioambientais no Brasil. A construção de hidrelétricas, estradas, aeroportos, portos, ferrovias, gasodutos, hidrovias e outros tipos de empreendimentos causam grandes intervenções físicas junto ao meio ambiente. Provoca entre outras degradações ambientais, perda de biodiversidade, deslocamentos compulsórios e em alguns casos se constituem em vetores não desejados de desenvolvimento.

A construção de hidrelétricas tem sido um setor sensível a esses problemas. A sua implementação tem se arrastado anos a fio, ainda na primeira fase de construção dos empreendimentos, durante o processo de licenciamento ambiental.

Os problemas são variados e não há consenso na sociedade em relação à origem desses problemas, que, invariavelmente tem provocado atrasos no cronograma estabelecido quando do planejamento das obras. 
Ao contrário do ambiente de diálogo orientado ao consenso pelos diversos atores em debate; tem prevalecido a lógica da disputa e da força, na qual a última palavra tem sido dada pelo Estado, como estabelece a legislação, mas sobre clima de pressões econômicas e políticas, onde nem sempre as questões técnicas e ambientais têm sido levadas em conta, como propugna a lei 6938/81 e as resoluções que normatizam o licenciamento ambiental.

A pesquisa em questão buscará na Modernização Ecológica, tanto na sua vertente discursiva, quanto na análise teórica, identificar os gargalos socioambientais que travam e constrangem a construção dos consensos necessários para a ampliação da capacidade energética do país, a partir do aumento do parque gerador de energia hidrelétrica. 



\section{LICENCIAMENTO AMBIENTAL NO BRASIL}
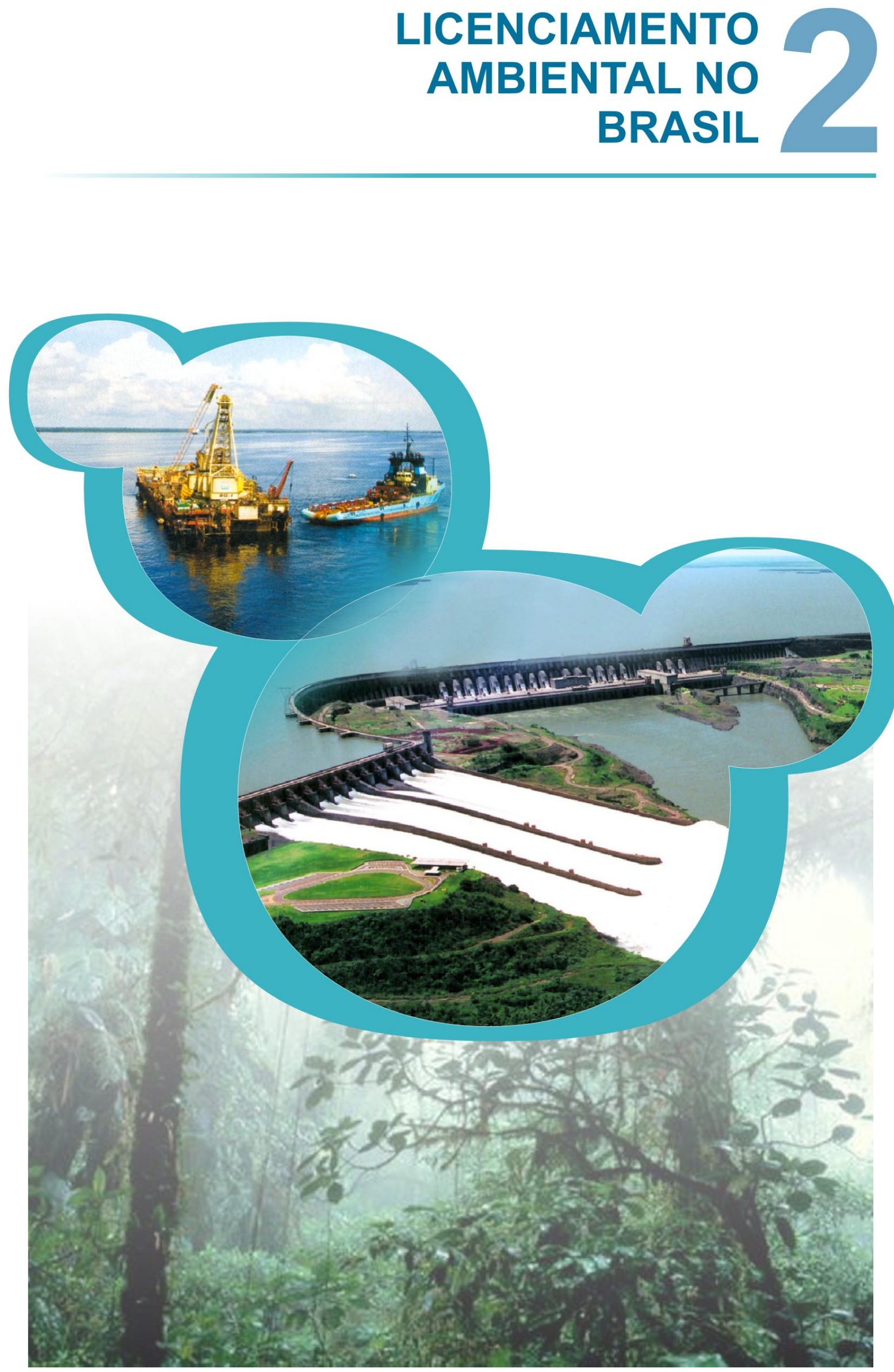


\section{Licenciamento Ambiental no Brasil}

\subsection{A LEI E O INSTRUMENTO}

O licenciamento ambiental passou a fazer parte do ordenamento político administrativo brasileiro como instrumento da Política Nacional de Meio Ambiente - PNMA previsto pela lei 6.938 de 1981.

A PNMA que estabelece em seu artigo $2^{\circ}$ como um dos seus objetivos "assegurar condições ao desenvolvimento socioeconômico"; e afirma no artigo $4^{\circ}$ como um de seus objetivos a “compatibilização do desenvolvimento econômico-social com a preservação da qualidade do meio ambiente e do equilíbrio ecológico" inovou ao estabelecer as bases de uma política de Estado em relação ao meio ambiente.

A própria lei constituiu-se como uma inovação e pode ser entendida no contexto já descrito anteriormente (capitulo teórico) do processo de tomada de consciência das questões relativas a interação ambiente e sociedade, reflete a resposta do país a crescente pressão pelo enfrentamento das questões ambientais.

Dentre os instrumentos de gestão ambiental estabelecidos pela lei 6.938/81, o Licenciamento Ambiental tem se constituído como um dos mais controversos.

Embora tenha sido previsto pela legislação nacional em 1981, o licenciamento ambiental no Brasil teve início na década de 70 quando, primeiro no estado do Rio de Janeiro, em 1975, e um ano depois em São Paulo fora instituído para orientar a ação dos governos locais em relação as "atividades industriais e certos projetos urbanos como aterros de resíduos e loteamentos” (SÁNCHEZ, 2006, pg. 81).

O Decreto-lei n ${ }^{\circ}$ 134/75 instituiu no Rio de Janeiro o Sistema de Licenciamento de Atividades Poluidoras, Tornou obrigatório o licenciamento de novos empreendimentos e determinou que os que já estivessem instalados seriam licenciados em etapas. Em São Paulo, a Lei nº 997/76 previu que a instalação, construção ou ampliação, bem como a operação ou funcionamento, de empreendimentos constantes na lei seriam passíveis de autorização do órgão estadual de controle da poluição do meio ambiente, mediante licenças de instalação e funcionamento (OLIVEIRA, 2005). 
Com a publicação da PNMA o licenciamento tem seu escopo de utilização ampliado, deixa de ser voltado apenas a atividades poluidoras e passa a ser aplicado a atividades que utilizam recursos ambientais ou com potencial de causar degradação ambiental.

A construção, instalação, ampliação e funcionamento de estabelecimentos e atividades utilizadoras de recursos ambientais, considerados efetiva e potencialmente poluidores, bem como os capazes, sob qualquer forma, de causar degradação ambiental, dependerão de prévio licenciamento de órgão estadual competente, integrante do Sistema Nacional do Meio Ambiente-SISNAMA, e do IBAMA, em caráter supletivo, sem prejuízo de outras licenças exigíveis (Art. 10 da lei 6.938/81).

Junto com o licenciamento ambiental, a avaliação de impacto ambiental -AIA, também foi estabelecida enquanto instrumento da Política Nacional de Meio Ambiente.

Os dois instrumentos que a princípio são independentes entre s $^{11}$, passam, em função do ordenamento jurídico a se complementarem, de maneira que hoje são até confundidos enquanto mesmo instrumento da gestão ambiental do país.

\subsection{QUADRO LEGAL}

Com a instituição da Política Nacional de Meio Ambiente, uma série de decretos, leis e resoluções destinadas a garantir a aplicação da lei foram publicados.

Em 1983, dois anos após a publicação da PNMA, o decreto nº 88.351 regulamentou a lei 6.938/81, mas foi revogado e substituído em 1990, pelo decreto de $n^{\circ} 99.274$ que manteve intacta a matéria referente ao licenciamento ambiental constante no decreto anterior.

O decreto de $1990^{12}$ no Art. $17 \S 1^{\circ}$ estabelece competência do Conselho Nacional do Meio Ambiente - Conama para fixar os critérios básicos, segundo os quais são exigidos estudos de impacto

\footnotetext{
${ }^{11}$ Os primeiros estudos de impacto ambiental de hidrelétricas no país foram feitos na década de 70, anteriormente à legislação que instituiu a avaliação de impacto ambiental. Sánchez (2006) apresenta dois fatores que influenciaram as primeiras avaliações ambientais no país:

a) fatores externos como a influência do que ocorria na legislação ambiental de outros países;

b) fatores internos como o nascimento do pensamento ecológico brasileiro, muito crítico ao modelo de desenvolvimento do qual a transamazônica e a UHE de Itaipu foram os maiores ícones.

${ }^{12}$ Antes de 1990, a resolução CONAMA 001/86 já havia definido o conceito de impacto ambiental, assim como listado quais atividades e tipologias de empreendimentos seriam passivas de licenciamento. No entanto, como o decreto 99.274/90 revogou o decreto de 1983 que regulamentava a lei 6.938/81, há essa aparente incongruência cronológica.
} 
ambiental para fins de licenciamento, assim como, define o conteúdo desses estudos:

a) diagnóstico ambiental da área;

b) descrição da ação proposta e suas alternativas;

c) identificação, análise e previsão dos impactos significativos, positivos e negativos.

O decreto $n^{\circ}$ 99.274/90 estabeleceu os três tipos de licenças emitidas pelo poder público durante o processo de licenciamento:

I - Licença Prévia (LP), na fase preliminar do planejamento de atividade, contendo requisitos básicos a serem atendidos nas fases de localização, instalação e operação, observados os planos municipais, estaduais ou federais de uso do solo;

II - Licença de Instalação (LI), autorizando o início da implantação, de acordo com as especificações constantes do Projeto Executivo aprovado;

III - Licença de Operação (LO), autorizando, após as verificações necessárias, o início da atividade licenciada e o funcionamento de seus equipamentos de controle de poluição, de acordo com o previsto nas Licenças Prévia e de Instalação (Art. 19, Decreto 99.274/90).

\subsection{RESOLUÇÕES CONAMA}

O Conama está previsto pelo artigo $6^{\circ}$ da Política Nacional do Meio Ambiente. É formado por representantes do poder público federal e dos estados, além de representantes da sociedade civil - empresários, sindicatos e ONGs.

Dentre suas atribuições, o conselho ficou incumbido de regulamentar a PNMA que também criou o Sisnama - Sistema Nacional de Meio Ambiente, estrutura composta por órgãos ambientais dos três níveis de governo: união, estados e municípios.

Em janeiro de 1986, o referido conselho definiu o conceito de impacto ambiental, por meio da Resolução Conama ${ }^{\circ} 01 / 86$, que no seu artigo $1^{\circ}$ considera impacto ambiental:

(...) qualquer alteração das propriedades físicas, químicas e biológicas do meio ambiente, causada por qualquer forma de matéria ou energia resultante das atividades humanas que, direta ou indiretamente, afetam:

I - a saúde, a segurança e o bem-estar da população;

II - as atividades sociais e econômicas;

III - a biota;

IV - as condições estéticas e sanitárias do meio ambiente;

$\mathrm{V}$ - a qualidade dos recursos ambientais.

A resolução $n^{\circ}$ 01/86 exige a realização de estudo de impacto ambiental - EIA para o licenciamento de atividades modificadoras do meio ambiente, estabelece a inclusão das questões socioeconômicas no diagnóstico ambiental e análise dos impactos ambientais do projeto e suas alternativas. No Art. $11 \S$ 
$2^{\circ}$, a resolução institui a Audiência Pública-AP como instrumento de informação sobre o projeto e seus impactos ambientais e discussão do Relatório de Impacto Ambiental - RIMA.

Em dezembro de $1987^{13}$, quase dois anos após a publicação da resolução 001/86, por meio da Conama 009 a realização das audiências é regulamentada: "expor ao público interessado o conteúdo do EIA em análise e do seu referido RIMA, dirimindo dúvidas e recolhendo dos presentes as críticas e sugestões a respeito".

As AP‘s são realizadas sempre que solicitadas por entidade civil, pelo Ministério Público - MP, ou por mais de cinqüienta cidadãos. Quando solicitadas conforme estabelecido pela legislação e não realizadas, uma eventual concessão da licença não terá validade.

A depender da localização geográfica dos solicitantes e da complexidade do empreendimento poderá haver mais de uma audiência que será conduzida pelo órgão licenciador que deverá garantir a discussão sobre o projeto e o RIMA em questão após a apresentação do projeto pelo proponente.

Um aspecto importante da resolução nº 09/87 é que por meio do seu Art. $8^{\circ}$ estabelece que:

Correrão por conta do proponente do projeto todas as despesas e custos referentes à realização do estudo de impacto ambiental, tais como: coleta e aquisição dos dados e informações, trabalhos e inspeções de campo, análises de laboratório, estudos técnicos e científicos e acompanhamento e monitoramento dos impactos, elaboração do RIMA e fornecimento de pelo menos 5 (cinco) cópias.

Nesse sentido, caberá ao interessado pelo projeto, atividade ou empreendimento todos os custos relacionados aos estudos que subsidiarão o processo de decisão a respeito da viabilidade ou não da proposta em análise.

Em 1997, o Conama publicou a resolução 237, onze anos após a 009/87. O ato normativo referido ao licenciamento ambiental ${ }^{14}$ trata de muitos temas que já tinham sido abordados, assim como de aspectos do sistema de licenciamento já definidos na lei.

\footnotetext{
${ }^{13}$ Embora aprovada em 1987, a resolução 009/87 só passou a vigorar em 5 de julho de 1990, quando foi publicada (MILARÉ, 2004,pg. 433).

${ }^{14}$ A numeração das diversas resoluções não são seqüenciadas, porque o Conama delibera sobre outros temas da agenda ambiental. Entre 1987 e 1997, o Conselho Nacional do Meio Ambiente publicou outras resoluções referentes a temas específicos do licenciamento - mineração, atividades de exploração de gás, petróleo e outros. Neste capítulo, nos interessam as questões gerais do sistema de licenciamento ambiental.
} 
A resolução 237/97 definiu o licenciamento ambiental como um

procedimento administrativo pelo qual o órgão ambiental competente licencia a localização, instalação, ampliação e a operação de empreendimentos e atividades utilizadoras de recursos ambientais, consideradas efetiva ou potencialmente poluidoras ou daquelas que, sob qualquer forma, possam causar degradação ambiental, considerando as disposições legais e regulamentares e as normas técnicas aplicáveis ao caso (Art. $1^{\circ}$, Resolução Conama 237/97).

A resolução estabeleceu parâmetros a partir dos quais se define a competência da União, Estados e Municípios para liderar cada processo de licenciamento, embora exerçam a liderança dos processos de maneira que as outras esferas possam ser solidárias e até co-responsáveis. Caberá ao IBAMA licenciar propostas:

I - localizadas ou desenvolvidas conjuntamente no Brasil e em país limítrofe; no mar territorial; na plataforma continental; na zona econômica exclusiva; em terras indígenas ou em unidades de conservação do domínio da União.

II - localizadas ou desenvolvidas em dois ou mais Estados;

III - cujos impactos ambientais diretos ultrapassem os limites territoriais do país ou de um ou mais Estados;

IV - destinados a pesquisar, lavrar, produzir, beneficiar, transportar, armazenar e dispor material radioativo, em qualquer estágio, ou que utilizem energia nuclear em qualquer de suas formas e aplicações, mediante parecer da Comissão Nacional de Energia Nuclear-CNEN;

V- bases ou empreendimentos militares, quando couber, observada a legislação específica" (Art. $4^{\circ}$, Resolução Conama 237/97).

A publicação da referida resolução foi acompanhada de um anexo de atividades ou empreendimentos sujeitos ao licenciamento ambiental.

\subsection{A CONSTITUIÇÃO DE 1988}

A Constituição Cidadã de 1988 corroborou com a PNMA quando no seu artigo 225 garantiu a todos os brasileiros o direito ao meio ambiente ecologicamente equilibrado, e o definiu como bem de uso comum do povo e essencial à sadia qualidade de vida, cabendo ao poder público e a coletividade o dever de defendê-lo e preservá-lo para as presentes e futuras gerações.

Diz ainda o artigo no $\S 1^{\circ}$ que a instalação de atividades causadoras de significativa degradação ao meio ambiente necessitarão de estudo de impacto ambiental, o qual deverá ter publicidade. 


\subsection{LICENCIAMENTO AMBIENTAL DE HIDRELÉTRICAS - A CONTROVÉRSIA}

A literatura acadêmica tem apontado conseqüências positivas e negativas como resultado da construção e operação de empreendimentos hidrelétricos. Os efeitos positivos; normalmente estão associados ao provimento de energia necessária ao desenvolvimento das sociedades e de seus processos produtivos, assim como à utilização múltipla - abastecimento, recreação, turismo e irrigação permitidos a partir do uso dos reservatórios destinados a acumular água para a produção de energia nos períodos de menor incidência de chuvas (TUNDISI, 2007).

Em relação aos aspectos negativos, são apontados diversos problemas ambientais: 1) alteração do regime hidrológico; 2) comprometimento das atividades à jusante da barragem e da qualidade das águas, em razão do caráter lêntico do reservatório; 3) dificuldade de decomposição dos rejeitos e efluentes; 4) assoreamento em virtude do descontrole no padrão de ocupação territorial nas cabeceiras dos reservatórios, submetidos a processos de desmatamento e retirada da mata ciliar; 5) emissão de gases de efeito estufa, particularmente o metano, decorrente da decomposição da cobertura vegetal submersa nos reservatórios; 6) sobrepressão sobre o solo e subsolo pelo peso da massa de água represada, podendo provocar sismos induzidos (BERMANN, 2007).

Além dos impactos no ambiente físico e biológico, as UHE’s provocam desorganização das condições socioeconômicas e culturais dos atingidos (TEIXEIRA et al, 2002).

A evidência dos impactos gerados por UHEs motivou que constassem na lista de atividades passíveis de estudo de impacto ambiental e licenciamento ambiental pela resolução Conama 001/86 reafirmada pela resolução 237/97.

A complexidade que envolve a matéria ambiental, por um lado, e a multiplicidade de atores sociais relacionados aos processos do licenciamento de hidrelétricas com seus diversos interesses, por outro, têm se constituído como impeditivos da formação de consenso a respeito da presença de UHEs na expansão da geração de energia elétrica.

A história recente da construção e implantação de UHEs no Brasil tem sido marcada pelo conflito entre empreendedores e os interesses locais - normalmente populações atingidas, o movimento social 
local e ONGs ambientalistas. Em algumas situações, o poder público local, alijado da discussão também tem composto o grupo dos que conflitam com os empreendimentos.

A base do conflito tem sido em torno da compensação às populações atingidas e a discussão do modelo de desenvolvimento. A questão socioeconômica tem sido o elemento impulsionador da mobilização social e o principal elemento motivador do conflito, embora o movimento ambientalista tenha tensionado em relação a sua agenda.

Duas situações concretas têm contribuído para essa característica do conflito:

O primeiro é o fato de a maior parte dos empreendimentos construídos estarem localizados no centrosul do país, região próxima aos principais centros de carga e mais antropizada que a região norte, onde está localizada parte significativa do potencial hidrelétrico do país ${ }^{15}$.

A construção de hidrelétricas tem provocado o deslocamento compulsório de inúmeras famílias de agricultores e ribeirinhos que, esquecidas pelas políticas públicas, normalmente vivem da interação com os rios represados para a operação hidrelétrica.

O processo de abandono da terra nem sempre tem sido acompanhado pelo reconhecimento do direito à indenização. Situação que já foi pior, durante a ditadura, mas que ainda hoje é fator gerador de conflito na medida em que empreendedores têm dificuldades de reconhecer o direito de não proprietários.

O segundo fato indutor dos atuais conflitos diz respeito à memória viva da sociedade de como as grandes obras de construção civil foram feitas em passado recente no país.

Durante o regime militar, as ações do setor pautavam-se pelo objetivo de garantir as condições à construção dos empreendimentos, entendidos como necessários à segurança nacional. A aquisição de áreas baseava-se em critérios de avaliação unilaterais, de cuja elaboração os proprietários não parti-

\footnotetext{
${ }^{15}$ De acordo com estudo do Banco Mundial sobre o licenciamento ambiental de hidrelétricas no Brasil, as hidrelétricas respondem por $85 \%$ da matriz elétrica brasileira. O potencial hidrelétrico brasileiro é estimado em $260 \mathrm{GW}$, do quais apenas 30\% estão em operação ou construção. Cerca de 43\% do potencial hidrelétrico e 64-66 \% dos projetos potenciais com custos competitivos estão situados na Região Norte, onde apenas $9 \%$ do potencial está aproveitado, contra cerca de $40 \%$ para as Regiões Nordeste e Sudeste/Centro-Oeste. Na Região Sul, quase 50\% do potencial hidrelétrico está aproveitado.
} 
cipavam. Não havia o reconhecimento dos não proprietários, de maneira que os trabalhadores rurais não obtinham nenhum tipo de reparação pela perda das condições objetivas de seu sustento.

Há um histórico de não reconhecimento do direito de parcelas significativas das populações atingidas por empreendimentos hidrelétricos no país, que foram e ainda são obrigadas a abandonar o lugar onde vivem e seus modos de vida sem nenhuma reparação destinada a lhes ressarcir as perdas.

A impossibilidade concreta da reconstituição dos seus modos de vida, uma vez que normalmente se tratam de famílias de trabalhadores com forte ligação com a terra, sem posses e que têm na sua força de trabalho o único instrumento de sobrevivência, tem levado à organização dessas populações. Organização que deu origem ao MAB. ${ }^{16}$

Há também um segundo grupo de populações atingidas e que estão protegidos pela Constituição brasileira devido a particularidade de sua cultura: indígenas e quilombolas, que muitas vezes não conseguem fazer avançar o debate sobre a titularidade das terras onde residem, devido ao interesse de grupos econômicos de utilizar esses territórios para formação do lago hidrelétrico. Em outros casos, não são reconhecidos pelos $\mathrm{EIA}^{17}$.

O movimento social, com destaque às ONGs ambientalistas ${ }^{18}$ têm feito da oposição à construção de hidrelétricas, a qualquer custo, um importante tema de sua agenda. Durante o regime militar ocorreram desastres ambientais significativos, como a UHE Balbina, que alagou $1580 \mathrm{~km}^{2}$ para produzir 225 MW e a construção de Tucuruí, que inundou $2000 \mathrm{~km}^{2}$ de florestas, prejudicando ribeirinhos e indígenas (MILARÉ, 2004).

Esse quadro vigente no país até o início dos anos 80; criou a cultura no setor elétrico na qual os empreendimentos assumem a primazia do processo. Fora dele, a organização crescente de setores sociais que se contrapõem a um modelo de desenvolvimento que tenha como contrapartida a destrui-

${ }^{16}$ O Movimento dos Atingidos por Barragens existe nacionalmente desde 1980. "A história dos atingidos por barragens no Brasil tem sido marcada pela resistência na terra, luta pela natureza preservada e pela construção de um projeto popular para o Brasil que contemple uma nova Política Energética justa, participativa, democrática e que atenda os anseios das populações atingidas, de forma que estas tenham participação nas decisões sobre o processo de construção de barragens, seu destino e o do meio ambiente" (http://www.mabnacional.org.br/historia.html).

${ }^{17}$ O EIA da UHE Irapé, MG, contratado pela CEMIG, não reconheceu o quilombo de Porto Cori.

${ }^{18} \mathrm{O}$ movimento ambientalista reflete a diversidade da sociedade brasileira. Não há posição homogênea contrária a UHEs, por princípio, embora existam instituições que se posicionem contrárias assim. 
ção ecológica irrefletida e a destruição do modo de sobrevivência de trabalhadores, de quilombolas, de indígenas e grupos já excluídos ${ }^{19}$.

\subsection{CONFLITOS E POSICIONAMENTOS DE ATORES SOCIAIS}

A produção acadêmica no campo das ciências sociais tem sido crítica quanto a maneira como o setor elétrico tem atuado para construir hidrelétricas. Tem prevalecido a percepção de que os avanços no discurso institucional do setor elétrico e de organismos internacionais não têm mudado o comportamento das empresas (VAINER, 2003).

Embora haja crescente aumento da legislação nacional, as comunidades atingidas pela construção de barragens continuam a ter problemas de reconhecimento de seus direitos. As transformações ocorridas no setor elétrico a partir de 1995, com a quebra do monopólio Estatal e privatização da distribuição e geração de energia constituíram-se em atraso no trato das questões socioambientais do setor.

A aprendizagem institucional, fruto do embate entre o movimento social com o Sistema Eletrobrás e que refletiu no $\mathrm{PDMA}^{20}$ de 1990, perdeu-se quando diminuiu a capacidade do Estado de planejar e construir UHEs (VAINER, 2007).

A razão de Estado sucumbe a rationale do capital e o PDMA, construído para orientar a ação das empresas estatais do setor elétrico passou a ser um documento referência:

"O Plano Diretor de Meio Ambiente do Setor Elétrico, que data de 1990, equaciona o problema de forma clara e precisa, e estabelece para o setor um conjunto de diretrizes que poderia ser aplicado em quase sua totalidade ainda hoje. Entretanto, as próprias mudanças no setor transformaram o documento estratégico apenas numa referência, o que não significa que as premissas sobre o qual foi delineado tenham perdido seu valor "(Banco Mundial, 2008, p. 14).

\footnotetext{
${ }^{19}$ Há na literatura acadêmica sobre ambiente e sociedade uma área denominada "Justiça Ambiental" que tem apontado o fato de que as populações excluídas socioeconomicamente têm sido obrigadas a arcar com a maior parte dos custos socioambientais do desenvolvimento (ACSELRAD, 2004).

${ }^{20}$ O Plano Diretor do Meio Ambiente de 1990 define os princípios básicos e diretrizes que configuram a postura do setor elétrico no trato das questões socioambientais nas etapas de planejamento, implantação e operação dos empreendimentos, sendo compatível com as diretrizes e instrumentos da Política Nacional do Meio Ambiente, suas reformulações e legislação complementar.
} 
As empresas de geração de energia hidrelétrica têm criado procedimentos "frios" e descomprometidos com os princípios da legislação vigente. Os RIMAs normalmente têm se transformado em peças dissociadas da realidade a qual se pretende intervir.

Um estudo comparativo de sete EIA/RIMAs de hidrelétricas concluiu que todos eles se caracterizavam pela fragilidade de conteúdo e omissão de impactos. As realidades são construídas sob uma visão estanque, sem levar em conta o processo histórico que as conformaram (TEIXEIRA ET AL., 2002) ${ }^{21}$.

O processo de licenciamento ambiental tem sido fraudado em sua lógica e princípios na medida em que os RIMA's não dão conta de toda a complexidade existente.

A complexidade presente no processo de interação subjetiva entre o homem e a natureza é secundarizada e as soluções apresentadas destinam-se tão somente a descobrir maneiras pelas quais o ambiente e suas complexidades socioculturais e naturais serão associadas ao projeto técnico a fim de que este seja aprovado.

A obra assume lugar central, é apresentada de forma inquestionável e inexorável. O ambiente é percebido como externalidade, paisagem que deve ser modificada e adaptada aos objetivos do projeto técnico (ZHOURI \& OLIVEIRA).

Sob a perspectiva da viabilização da produção de energia e do caráter vital que esta tem para a sociedade, as populações são tratadas como problemas a serem solucionados, ante a sua condição de sujeitos mobilizados por direitos. "Há uma inversão perversa da hierarquia entre a razão técnica e razão social (CASTRO, 1988, p. 8)", onde o desenvolvimento econômico prevalece sobre as necessidades humanas. Uma inversão de princípios, pois as populações perdem sua condição de sujeitos frente aos empreendimentos.

No Vale do Jequitinhonha, MG, a Comunidade Quilombola de Porto Cori foi omitida do EIA/RIMA (FUNDAÇÃO CULTURAL PALMARES, 1998). O mesmo aconteceu com os Waimirim-Atroari,

\footnotetext{
${ }^{21}$ A 4 a Câmara da Procuradoria Geral da República realizou estudo sobre uma série de EIA/Rima's e teve conclusão semelhantes. Iremos discutir este estudo mais a frente.
} 
que tiveram duas de suas aldeias omitidas do Plano Diretor da Eletrobrás e do EIA feito para a construção da UHE Balbina (CASTRO, 1988).

Em 2004, o Consórcio Candonga, formado pelas empresas Vale do Rio Doce e Alcan, foi denunciado na ONU por violar os direitos de moradia dos moradores dos povoados de Soberbo e Santana do Deserto, em Minas Gerais ${ }^{22}$.

Em outubro de 2005, o Brasil foi denunciado à Comissão Interamericana de Direitos Humanos da Organização dos Estados Americanos - OEA, devido a violações praticadas pelo Consórcio Enercam contra as populações atingidas pela UHE Campos Novos.

Entre as violações constam:

(...) a destruição das bases materiais e culturais de que dependem os grupos populacionais atingidos, inviabilizando a sustentação de seus sistemas produtivos tradicionais e sua reprodução sócio-cultural; os deslocamentos forçados, a expropriação e a degradação de seus bens ambientais que ameaçam diretamente a integridade física e moral dos grupos atingidos, colocando em risco a sua sobrevivência devido à privação dos seus meios de subsistência. (http://www.mabnacional.org.br/noticias/ $\underline{101005}$ oea.htm).

A inversão da primazia da razão técnica sobre o humano tem levado as comunidades a serem as últimas a saber o que acontecerá com suas vidas. Embora o PDMA I e II, as diretrizes para elaboração de Projeto Básico de Usinas Hidrelétricas da Agência Nacional de Energia Elétrica - ANEELe a Resolução 001/86 do CONAMA sejam precisos ao explicitar a necessidade do estabelecimento de canais efetivos de diálogo e discussão com as populações em torno dos projetos, tem havido pouco diálogo e uma lógica que vê no licenciamento ambiental uma etapa burocrática a ser vencida.

O conhecimento do projeto se dá sob o fato consumado, as comunidades não têm a oportunidade de intervir na concepção do projeto e na melhor das hipóteses negociam uma alternativa menos danosa às suas vidas.

Essa situação, além de uma ruptura nas vidas das comunidades com relação ao futuro, interfere negativamente antes do início das obras, pois, como as informações são escassas e espaçadas, dificultam e,

\footnotetext{
${ }^{22}$ O Relatório elaborado pelo MAB, Comissão Pastoral da Terra, Núcleo de Assessoria às Comunidades Atingidas por Barragens e Justiça Global entregue ao Relator Especial da ONU para o Direito à Moradia Adequada, traz uma série de outras denúncias, inclusive a do assassinato de um dos atingidos que mostrou-se desfavorável a forma como o Consórcio conduziu o processo junto às comunidades atingidas.
} 
às vezes, até impedem o processo de tomada de decisão sob aspectos cotidianos das famílias. Ampliação e renovação de plantios, construção ou reforma da casa ou de galpões, e aquisição de maquinário ficam comprometidos na medida em que todo o investimento poderá ser perdido ${ }^{23}$.

Entre o anúncio da obra da barragem de Itá, no Rio Grande do Sul, e o cadastramento das quatro mil famílias passaram-se oito anos. Nesse período os produtores rurais não realizaram investimentos na manutenção e aquisição de equipamentos e benfeitorias, o que acabou por reduzir a produtividade (BERMANN, 1995).

Em Porto Cori, ao falar sobre como o empreendimento já influenciava a vida da comunidade, um senhor desabafou:

Faz já não sei quanto tempo que dizem que a barragem vai sair, nesse tempo não podemos reformar nossas casas, meu filho não pode se casar e fazer a casa dele, não podemos aumentar nossas roças, enfim, não podemos planejar nossas vidas (CONTRAPONTO, 2001, p. 16).

As populações não são consultadas na fase de elaboração dos projetos para que sejam ouvidas em torno das alternativas de manejo do meio ambiente e adequação de suas atividades produtivas e seus modos de vida frente ao novo empreendimento.

Ao contrário, só irão tomar conhecimento da proposta no momento da Audiência Pública, quando os projetos são apresentados de maneira a cumprir uma exigência legal, ante o princípio de que esse seria também um momento no qual as comunidades poderiam fazer críticas, sugestões e incorporar suas demandas ao projeto.

A maneira como os recursos são utilizados acabam por tolher a participação das comunidades. Não são privilegiadas estratégias que estimulem a participação cidadã.

Em alguns casos, como a PCH de Aiuruoca, em Minas Gerais, a Audiência Pública foi realizada após a elaboração do parecer técnico do órgão estatal responsável por elaborá-lo, o que impossibilitou que o parecer incorporasse as demandas da população local (ZHOURI, 2005).

\footnotetext{
${ }^{23}$ Durante o ciclo de audiências da UHE Tijuco Alto, em ao menos 20 intervenções, $11 \%$ do total, a CBA foi questionada pelos prejuízos ocasionados a economia local, mas também às famílias ribeirinhas que moram ou moravam na área onde ela adquiriu terras na década de 90 e que nos últimos 20 produzem aquém do que poderia. $\mathrm{O}$ prefeito do município de Ribeira Jonas Dias Batista afirmou categoricamente em uma longa intervenção na audiência em seu município que a indefinição a respeito do empreendimento causou prejuízos à região.
} 
Em outras situações, como a da UHE de Candonga,

(...) todo mundo queria saber mais sobre o projeto que estava sendo apresentado como um "presente de Deus". No momento da explanação, entretanto, o recurso do tecnicismo afastou a capacidade de compreensão e de participação das pessoas. Apesar de muitos ficarem com dúvidas a respeito dos benefícios que o projeto traria para eles, ninguém disse uma palavra. (...) As pessoas não votaram nem a favor nem contra. Ninguém sabia como falar, o que dizer ou perguntar" (BARROS, 2004. p. 30) ${ }^{24}$.

Estes problemas causados por um modelo assimétrico na relação entre as comunidades atingidas de um lado, e as empresas do outro, tem impulsionado um processo de disputa na sociedade brasileira em torno do instrumento da licença ambiental.

A tese, não raro encontrada nos meios de comunicação $0^{25}$ e defendida por alguns setores do governo ${ }^{26} \mathrm{e}$ principalmente do empresariado brasileiro de que o licenciamento ambiental é um fator impeditivo ao desenvolvimento do país, é uma contradição criada pela ineficiência dos projetos hidrelétricos que não incorporam a variável ambiental e são definidos a partir das variáveis econômica e técnica (MORETTO, 2008).

Para Moretto, o licenciamento ambiental é levado à condição de conflito político nacional para justificar as pressões em torno da flexibilização do licenciamento e os quadros técnicos dos órgãos ambientais concedam licenças inadequadas.

Opinião compartilhada pelo ex-secretário executivo do MMA, Cláudio Langone ${ }^{27}$. Ao comentar as constantes reportagens em jornais de circulação nacional e TV’s sobre a lentidão do sistema de avaliação, Langone afirmou que a aparição cíclica da acusação que o sistema de licenciamento é lento, radical e contrário ao desenvolvimento não tem outra função se não a de servir aos interesses de

\footnotetext{
${ }^{24}$ Depoimento de Maria das Graças Reis, moradora de Nova Soberbo, povoado atingido pela UHE de Candonga.

${ }^{25}$ Folha online - 21/12/2003. "IBAMA diz que é acusado de proteger a lei ambiental". Em entrevista, o diretor de licenciamento do IBAMA, Nilvo Alves da Silva diz que as críticas que os empresários têm feito ao processo de licenciamento são uma tentativa de constranger a lei ambiental no Brasil. Para Alves o IBAMA tem sido acusado de proteger o ambiente.

(http://www1.folha.uol.com.br/folha/dinheiro/ult91u78416.shtml)

Ainda sobre essa situação a Associação dos Servidores do IBAMA-DF, lançou documento intitulado "A verdade sobre o Licenciamento Ambiental", no qual defende os procedimentos adotados pelos IBAMA. Para os servidores uma licença não se trata de um documento burocrático e sim que determinado empreendimento tem viabilidade ambiental. Diz ainda o texto que é em nome do desenvolvimento do país que os órgãos ambientais exigem garantias que assegurem a qualidade de vida das presentes e futuras gerações. O texto é de setembro de 2004.

${ }^{26}$ Estudo do Banco Mundial afirma que dentro do próprio governo federal há quem considere o licenciamento ambiental moroso e burocrático e que a expansão do parque gerador de energia hidrelétrica opõe setores do próprio governo.

${ }^{27}$ Claudio Langone foi entrevistado em 24/03/08 em Brasília.
} 
grupos econômicos poderosos que fazem da crítica pública e reiterada ao licenciamento uma estratégia para enfraquecê-lo.

\subsection{OUTRAS OPINIÕES: O QUE DIZEM OS ATORES, SUJEITOS DA CONTROVÉRSIA}

Ainda sob a influência traumática do apagão ocorrido em 2001, quando a sociedade foi compulsoriamente chamada a racionalizar seu consumo de energia, a gestão do Presidente Lula dedicou especial atenção à expansão do parque gerador de energia.

As iniciativas no âmbito federal preocupadas em garantir as condições políticas e administrativas para a construção de novas hidrelétricas tiveram na criação do Novo Marco regulatório para o Setor Elétrico em 2004 o movimento mais emblemático.

Entre as mudanças ocorridas na esteira do novo marco regulatório, duas dizem respeito diretamente a interface da expansão do sistema com o licenciamento ambiental:

1. Exigência da emissão da LP para os empreendimentos serem licitados nos leilões de venda de energia nova;

2. A criação da EPE-Empresa de Pesquisa Energética, autarquia responsável por planejar a expansão do setor elétrico.

Na década de 90, o país rompeu com a tradição de planejamento centralizado do sistema elétrico e influenciado pelos ventos do neoliberalismo, conferiu ao capital privado a primazia da decisão sobre a expansão do sistema. A quebra do monopólio estatal para geração, transmissão e distribuição de energia é apresentada como um dos motivos que iriam contribuir com o apagão em 2001 (SAUER, 2003).

O sistema de concessões que leiloava os aproveitamentos antes de comprovada a viabilidade ambiental do projeto, foi também considerado um dos gargalos do sistema, pois uma vez licitados, esperava-se a adição da energia na matriz energética; mas muitos empreendimentos não conseguiam as licenças necessárias, causando incerteza e insegurança na disponibilidade da energia. 
Como passou para o setor privado a responsabilidade pela proposição dos empreendimentos, o Brasil deixou de investir em estudos de inventário de bacias e em análises de viabilidade de novos empreendimentos, e em função disso, o portfólio nacional de hidrelétricas para entrar no sistema é pequeno. Essa situação gera tensão no sistema quando há atrasos no cronograma das UHEs.

O número exíguo de projetos hidrelétricos aptos a fazer parte do sistema de geração tem contribuído para que as termelétricas ${ }^{28}$ - UTEs ganhem importância estratégica na matriz energética, uma vez que estes empreendimentos demoram menos entre a decisão de fazê-los e sua entrada em operação e têm licenciamento menos complexo.

No entanto, as dificuldades que o país tem tido na relação com a Bolívia, nossa principal fonte de suprimento de gás, acabam por manter o clima de tensão no sistema, uma vez que por conta de questões fora do controle do país, o Brasil ${ }^{29}$ pode ficar sem o gás necessário para fazer funcionar as plantas das UTEs a gás ${ }^{30}$.

Nesse sentido, a EPE tem importância estratégica já que irá coordenar as Avaliações Ambientais Integradas - AAIs das bacias hidrográficas, a fim de que os novos aproveitamentos hidrelétricos a serem leiloados já o serão com a LP concedida.

Com a EPE à frente das AAIs espera-se que haja mudanças em relação a dois importantes problemas relacionados ao licenciamento ambiental de hidrelétricas no Brasil:

1. Qualidade dos estudos de impacto ambiental, uma vez que terão supervisão metodológica e estarão sendo acompanhados por um organismo de governo com expertise de planejamento;

\footnotetext{
${ }^{28}$ Parte significativa das Termelétricas que entraram no sistema são a gás, mas há também UTEs a carvão, programadas para entrar em operação. As usinas nucleares também são termelétricas.

${ }^{29}$ Nos últimos anos o país descobriu grandes jazidas de gás em seu subsolo, o que no médio e longo prazos poderá nos garantir auto-suficiência na utilização do produto. No entanto, o início da exploração em águas profundas, assim como, a construção de refinarias demanda tempo e, no curto prazo, o país depende do gás Bolíviano tanto para fazer funcionar as termelétricas a gás, como parte do parque industrial do Sul e Sudeste, e razoável frota de veículos. A Bolívia tem gás, mas sob constante instabilidade política tem tensionado por constantes mudanças sob o acordado, ora em relação ao preço, ora em relação a disponibilidade do produto.

${ }^{30}$ Além do problema de suprimento do gás boliviano, há ainda a forte demanda interna pelo uso do combustível. Por conta do apagão de 2001, muitas indústrias fizeram a conversão de suas plantas produtivas e passaram a utilizar o gás como fonte de energia. Nos últimos anos houve também forte crescimento da frota de veículos a gás em todo país.
} 
2. Criação de uma carteira ampla de projetos hidrelétricos com viabilidade ambiental comprovada, e aptos a serem leiloados, uma vez que a EPE coordena atualmente a AAI de inúmeras bacias - Rio Paraíba do Sul, Rio Doce, Rio Tocantins, Rio Paranaíba, Rio Parnaíba, Rio Uruguai ${ }^{31}$

A pressão sobre o sistema de licenciamento ambiental do país, e sua interface com a necessária expansão do parque de geração de energia hidrelétrica, motivou uma série de iniciativas tendo em vista a identificação dos gargalos do sistema de licenciamento e busca das possíveis soluções:

I. Criação do Grupo de Trabalho Interministerial no âmbito da Casa Civil para tratar da situação do Atingidos por barragem (2003 - 2005);

II. Mesa de negociação entre MMA e ABDIB para discutir avanço da agenda de infraestrutura no tocante ao licenciamento (2004-2005);

III. Acordo de Cooperação Técnica entre o Ministério do Meio Ambiente e o Fórum Brasileiro de ONGs e Movimentos Sociais para o Meio Ambiente e o Desenvolvimento (FBOMS) em junho de 2005;

IV. Em interação com o MME, o Banco Mundial fez estudo intitulado: “Licenciamento Ambiental de Empreendimentos Hidrelétricos no Brasil: Uma Contribuição para o Debate (2006 - 2008)";

Todas essas iniciativas impulsionaram que os diversos atores sociais envolvidos com o licenciamento ambiental de hidrelétricas se posicionassem a respeito deste instrumento.

Na maioria das vezes, estes players se manifestaram a partir de documentos que iremos analisar individualmente a fim de identificar consensos e dissensos a respeito do licenciamento ambiental.

\footnotetext{
${ }^{31}$ Fonte: www.epe.gov.br/Lists/MeioAmbiente/MeioAmbiente.aspx Último acesso em 23/11/2008 às 9:41
} 


\section{8 'LICENCIAMENTO AMBIENTAL DE EMPREENDIMENTOS HIDRELÉTRICOS NO BRASIL:UMACONTRIBUIÇÃOPARAODEBATE"'OESTUDODOBANCOMUNDIAL ${ }^{32}$}

Dentre os documentos que tivemos acesso e que iremos apresentar e discutir por ocasião da pesquisa, o trabalho publicado pelo Banco Mundial é a iniciativa de maior profundidade que avalia o estado da arte do licenciamento ambiental no país.

O trabalho publicado em março de 2008; talvez seja o único documento produzido sobre o licenciamento ambiental de hidrelétricas no Brasil, no qual conste a posição de todos os principais atores envolvidos no dia a dia do licenciamento ambiental a respeito dos problemas a serem superados tendo em vista a necessidade do país de fazer avançar o parque gerador de energia hidrelétrica.

A publicação assinada pelo organismo internacional é um marco na discussão do licenciamento ambiental do país semelhante ao relatório da Comissão Mundial de Barragens, porque ajuda a desnudar o comportamento sistêmico de todos os atores, contribuindo definitivamente para o fim de posicionamentos maniqueístas relacionados aos conflitos originados em torno do licenciamento ambiental no Brasil.

O estudo inova ao tentar articular o ponto de vista crítico dos atores sociais envolvidos no debate a respeito do licenciamento ambiental no país sob duas perspectivas:

1. Do ponto de vista dos problemas concretos relacionados ao licenciamento ambiental, identifica-os, discute-os e sugere caminhos para ajudar na solução do problema;

2. Contribui com a percepção e a legitimidade da discussão de determinados problemas relacionados ao tema que os atores têm dificuldade de assumir publicamente. Parte do posicionamento público dos setores sociais envolvidos nos conflitos relacionados ao licenciamento ambiental, normalmente, só leva em conta o seu problema. A sistematização e discussão de toda problemática relativa ao tema, de forma conjunta,

\footnotetext{
${ }^{32}$ Embora o trabalho seja apresentado pelo Banco Mundial, antes de abrir o primeiro capítulo a publicação traz uma nota, no mínimo curiosa: "As opiniões, interpretações e conclusões apresentadas neste estudo não devem ser atribuídas, de modo algum, ao Conselho Diretor do Banco Mundial ou aos países por ele representados, inclusive o governo brasileiro. O Banco Mundial não garante a precisão da informação incluída nesta publicação e não aceita responsabilidade alguma por qualquer conseqüência de seu uso" Grifo meu. Sendo assim, faz-se necessário esclarecer que quando nos referirmos ao estudo e as informações nele contidas, pressupõe-se que o Banco Mundial não tem nenhuma responsabilidade sobre as informações imputadas a seu estudo.
} 
contribuem para uma visão mais sistêmica da situação, e lança as bases para um processo de discussão mais qualificado, sobretudo com os diversos atores reconhecendo a legitimidade dos problemas e posições uns dos outros.

O documento produzido pelo organismo internacional tem indubitável qualidade técnica. As premissas sob as quais constrói a reflexão, demonstra a complexidade do debate:

(...) licenciamento ambiental de empreendimentos hidrelétricos no Brasil é percebido como um grande obstáculo, resultando em atrasos no desenvolvimento dos empreendimentos (...), e (...) como o principal instrumento de gestão ambiental garantidor da qualidade do meio ambiente no país (BANCO MUNDIAL, 2008, p. 11).

Em meio a essa dicotomia tomada como premissa; o estudo afirma que entre os diversos atores relevantes do processo de licenciamento há o consenso de que é preciso haver mudanças na aplicação do instrumento de modo a torná-lo mais eficiente ou que, ao menos deixe de ser percebido como algo ineficiente.

A contribuição do Banco Mundial ao debate sobre o licenciamento de UHEs no Brasil apresenta em diversos momentos a dicotomia tomada como premissa do estudo, como se estivesse ela mesma a orientar e influenciar o licenciamento de hidrelétricas.

Os dois quadros abaixo apresentam o ambiente de contradição apresentado pelo estudo.

\section{Quadro 03 - Comparativo das posições presentes nas duas visões que disputam o licenciamento de hidrelétricas.}

\begin{tabular}{|c|c|}
\hline Licenciamento Como Algo Necessário & Licenciamento Como Entrave \\
\hline $\begin{array}{l}\text { Principal instrumento de gestão ambiental } \\
\text { garantidor da qualidade do meio ambiente } \\
\text { no País. }\end{array}$ & $\begin{array}{l}\text { Entrave ao desenvolvimento de atividades } \\
\text { econômicas. }\end{array}$ \\
\hline $\begin{array}{l}\text { Com a redemocratização do país, a adoção } \\
\text { da Constituição Federal de } 88 \text { e com as } \\
\text { mudanças radicais ocorridas no setor } \\
\text { elétrico, o quadro anterior de falta de } \\
\text { diálogo e uso da força na liberação de áreas } \\
\text { necessárias à construção de UHEs se } \\
\text { inverteu. As comunidades locais, com } \\
\text { ampla capacidade de mobilização e } \\
\text { freqüentemente apoiadas por ONGs e, via } \\
\text { de regra, ainda respaldadas pelas ações do } \\
\text { Ministério Público (MP), têm hoje um } \\
\text { grande poder de negociação no âmbito das } \\
\text { concessionárias do setor elétrico, } \\
\text { garantindo seus legítimos direitos. }\end{array}$ & $\begin{array}{l}\text { No período pós-64 as empresas não } \\
\text { respeitavam os direitos das comunidades } \\
\text { locais impactadas pelas hidrelétricas e, } \\
\text { acreditando defender um interesse social } \\
\text { maior da sociedade brasileira, } \\
\text { implantavam as usinas ao menor custo } \\
\text { possível. O benefício refletia-se em tarifas } \\
\text { menores. Hoje, os interesses difusos do } \\
\text { restante da população brasileira, } \\
\text { potencialmente beneficiária dos } \\
\text { empreendimentos elétricos, via tarifas } \\
\text { mais acessíveis, não são mais defendidos } \\
\text { de forma articulada ao longo do processo. }\end{array}$ \\
\hline $\begin{array}{l}\text { Complexas questões ambientais e sociais a } \\
\text { ele atreladas. }\end{array}$ & $\begin{array}{l}\text { Vantagem comparativa do Brasil em } \\
\text { termos de potencial hidrelétrico. }\end{array}$ \\
\hline
\end{tabular}




\section{Quadro 04 - Comparativo da relação entre os setores ambiental e elétrico e suas interfaces com licenciamento de hidrelétricas}

\begin{tabular}{|l|l|}
\hline Setor Ambiental & Setor Elétrico \\
\hline $\begin{array}{l}\text { As regras do licenciamento ambiental } \\
\text { mantêm-se fundamentalmente inalteradas } \\
\text { desde suas origens e os órgãos ambientais } \\
\text { ainda não alcançaram um significativo } \\
\text { aumento de capacidade institucional. }\end{array}$ & $\begin{array}{l}\text { Houve profunda transformação nos } \\
\text { étimos } 10 \text { anos, mas suas regras ainda não } \\
\text { estão sedimentadas. }\end{array}$ \\
\hline $\begin{array}{l}\text { Mais antigo e consolidado sistema de } \\
\text { licenciamento ambiental, contando } \\
\text { nacionalmente com ampla capacidade } \\
\text { técnica. }\end{array}$ & $\begin{array}{l}\text { Modelo regulatório do setor elétrico } \\
\text { encontra-se em verdadeira ebulição, } \\
\text { enfrentando mudanças que indicam que } \\
\text { ele não está sedimentado. }\end{array}$ \\
\hline $\begin{array}{l}\text { Existe muita cautela e um ritmo mais } \\
\text { lento. Dados e informações Ambientais } \\
\text { serem tipicamente complexos e difíceis de } \\
\text { obter e analisar. }\end{array}$ & $\begin{array}{l}\text { Há pressa do lado do setor elétrico. A } \\
\text { energia é um insumo fundamental ao } \\
\text { desenvolvimento da sociedade. }\end{array}$ \\
\hline $\begin{array}{l}\text { Preocupação - Como melhor gerenciar os } \\
\text { compromissos e a questão ambiental. }\end{array}$ & $\begin{array}{l}\text { Preocupação - A necessidade de } \\
\text { crescimento do país. }\end{array}$ \\
\hline
\end{tabular}

Fonte: Banco Mundial, Licenciamento Ambiental de Empreendimentos

Hidrelétricos no Brasil: Uma Contribuição para o Debate Capítulos I e II.

O trabalho do Banco Mundial envolveu o estudo de caso do licenciamento de quatro empreendimentos hidrelétricos (Aimorés, Ipueiras, São Salvador e Itumirim) escolhidos em comum acordo com o MME, MMA, IBAMA e ANEEL.

O trabalho contou com a interação entre a equipe de consultores e representantes dos diversos atores institucionais envolvidos no licenciamento ambiental de hidrelétricas ${ }^{33}$, sobretudo os atores da esfera governamental, (MMA, IBAMA, MME, EPE, ANEEL, Ministério do Planejamento e Casa Civil), do MP (Federal e Estadual/SP), com o Poder Judiciário e com o setor privado (ABDIB, FIESP e outros) e ONGs.

O trabalho dos consultores do Banco Mundial busca, a partir da indicação dos problemas enfrentados pelos diversos atores institucionais, entender as causas das principais críticas que eles fazem entre si no embate a respeito dos rumos do licenciamento no país e indicar soluções aos problemas identificados.

O cenário social e econômico do qual parte a análise dos consultores, de alguma forma explicita o

\footnotetext{
${ }^{33}$ Alguns deles coincidentemente também entrevistados para esta pesquisa.
} 
perfil do estudo, que é mais próximo dos argumentos que empreendedores ${ }^{34}$ e setores do Ministério das Minas e Energia ${ }^{35}$ têm trazido ao debate.

Em outras palavras, o estudo em discussão, tem como foco central como "destravar" o licenciamento ambiental de hidrelétricas e garantir a rápida expansão do parque gerador de hidreletricidade. Nesse sentido, ainda que com muito cuidado, explicita certo desconforto diante do fato que a organização social é um fator que demanda um comportamento de diálogo e negociação por parte do setor elétrico.

\subsubsection{Licenciamento Ambiental e o dilema da maior participação social}

No Quadro 1. "Incentivos e cooperação entre os atores: pontos a destacar" (BANCO MUNDIAL, 2008, p. 12), o estudo descreve o cenário que origina os atuais conflitos e disputas em torno do licenciamento ambiental considerando que:

Com a democratização da sociedade brasileira, se por um lado as comunidades passam a ter instrumentos efetivos para se contrapor às arbitrariedades praticadas pelo setor elétrico durante os anos de ditadura, e adquirem mais força do que outrora no processo de negociação, inclusive com o respaldo do Ministério Público, por outro,

“os interesses difusos do restante da população brasileira, potencialmente beneficiária
dos empreendimentos elétricos via tarifas mais acessíveis, não são mais defendidos de
forma articulada ao longo do processo. O mesmo raciocínio se aplica às questões
ambientais, nunca ficando inteiramente claro quais os potenciais grupos beneficiados
e quais os negativamente impactados, e muito menos as magnitudes relativas desses
custos e benefícios para a sociedade como um todo" (BANCO MUNDIAL, 2008, p. 12).

No mesmo quadro, o estudo apresenta a corriqueira crítica que tem sido feita em relação a participação do MP nos processos de licenciamento de que a instituição tem tomado posições intransigentes. Mas, esclarece o texto, a legislação confere ao Ministério Público o sentido de tornar o licenciamento ambiental estrito e rigoroso, e não de balizar custos e benefícios, prós e contras das diversas ações de controle ambiental em questão.

\footnotetext{
${ }^{34}$ Entrevistamos representantes dos diversos atores institucionais - empreendedores (ABCE e CBIEE), governo (MME, MMA, IBAMA), ONGs; envolvidos com o licenciamento ambiental no país. Motivo pelo qual, sempre que necessário iremos nos referir a posições manifestas por esses atores durante as entrevistas.

${ }^{35}$ Do ponto de vista da pesquisa, entendemos os vieses específicos do discurso e da posição de cada um dos atores como algo natural, tendo em vista que seus posicionamentos refletem seus interesses orientados pelo papel social que cada um desempenha na sociedade.
} 
Sobre o Ministério Público os consultores dirão que a instituição tem tido papel decisório sobre assuntos que não são de sua competência como:

(...) (i) definição da matriz energética nacional; (ii) organização territorial do sistema de geração de energia; (iii) estabelecimento de critérios; e metas de desenvolvimento econômico regional e estruturação para atendimento dessas demandas; (iv) estabelecimento de prioridades de interesses econômicos e ambientais; e (v) valoração ou não dos impactos decorrentes (BANCO MUNDIAL, 2008, p. 44-45).

Sempre reconhecendo a autonomia e independência do Ministério Público; o trabalho aponta para a falta de correspondência internacional entre o poder de organismos semelhantes nos EUA, França e Itália e o MP no Brasil para sugerir que a participação de promotores e procuradores se dê sob os aspectos legais do licenciamento e não em relação a atos técnicos e administrativos.

O trabalho do Banco Mundial convoca o "Conselho Nacional do Ministério Público, para incluir no seu planejamento estratégico a definição de planos de metas para aumento da eficiência, aperfeiçoamento e desburocratização" (2008, p. 45).

A crítica que acusa o MP de extrapolar sua competência tem sido recorrente. Na entrevista que nos concedeu a Procuradora Maria Luíza Grabner ${ }^{36}$ quando confrontada com essa afirmação respondeu que não foge a competência do Ministério Público zelar para que os documentos técnicos e o próprio processo administrativo estejam em acordo com as exigências da lei. A procuradora que teve forte atuação no primeiro processo de licenciamento da UHE Tijuco Alto citou que o estudo feito pela $4^{\text {a }}$ Câmara de Coordenação e Revisão constatou fragilidade recorrente nos estudos socioeconômicos nos EIA de hidrelétricas.

Para Maria Luíza Grabner essa visão que está se criando em torno do Ministério Público, acontece porque a independência respaldada pela lei, a estrutura material com que conta a instituição, além do reconhecimento social crescente, tem permitido ao MP atuar decisivamente em torno de questões de interesse coletivo da sociedade ou das minorias, muitas vezes contrariando grandes interesses.

Como os órgãos ambientais carecem de estrutura a altura de sua missão e estão sujeitos a pressões, o

\footnotetext{
${ }^{36}$ A entrevista com a procuradora, que faz parte do Grupo de Trabalho "Licenciamento de Grandes Empreendimentos", também responsável pela elaboração do estudo sobre deficiências recorrentes dos EIA/RIMAs, foi concedida no dia 26/02/09.
} 
MP tem ocupado o papel de zelar pela aplicação da legislação que é clara e vem sendo sistematicamente não cumprida em sua totalidade.

A judicialização do processo de licenciamento é outro fator ao qual o setor empreendedor ${ }^{37}$ se refere com frequiência, e que o relatório aborda. O texto apresenta dados da pesquisa realizada pelo Instituto Socioambiental em parceria com o Ministério da Justiça e a Procuradoria Geral da República de que $60 \%$ das tentativas de paralisação de um empreendimento vingam.

A alternativa sugerida a essa situação é a criação de varas especializadas e Câmaras de Mediação e Conciliação de Conflitos Ambientais no âmbito do Poder Judiciário, além da contratação de corpo técnico independente capacitado e legitimado para esclarecer as controvérsias ${ }^{38}$.

Para projetos que sejam de alto risco ou muito controversos, e que envolvam preocupações multidimensionais ou sérias de ordem ambiental, é recomendável a constituição de um painel consultivo independente formado por especialistas ambientais reconhecidos internacionalmente para abordar todos os aspectos do projeto relevantes para a avaliação ambiental (BANCO MUNDIAL, 2008, pg.46).

\subsubsection{O Tempo da Licença - IBAMA fragilizado X Estudos de Impacto ruins ${ }^{39}$}

O Estudo do Banco Mundial constatou que a Licença Prévia (emitida em 2,7 anos) é responsável por quase $80 \%$ do tempo que o empreendimento leva para obter a Licença de Instalação (3,4 anos) e que a elaboração do Termo de Referência (1,1 ano) representa 40\% do tempo necessário a obtenção da LP(BANCO MUNDIAL, 2008, p.62).

Na prática, de acordo com o levantamento feito pelos consultores do Banco Mundial, em média, o IBAMA gasta 394 dias para dizer o que deve conter no estudo de impacto ambiental e o empreendedor leva 219 dias para fazer todo o estudo.

\footnotetext{
${ }^{37}$ A judicialização é fonte de custos financeiros para o empreendedor. Primeiro porque se o processo de licenciamento é paralisado, isso tem um custo, uma vez que todo o organograma do empreendimento é alterado. Depois, uma vez judicializado o processo, o empreendedor terá o custo adicional de formar provas contrárias e formular ações que destravem o processo e o mesmo possa seguir o curso estabelecido pelo organograma.

${ }^{38}$ No caso das UHEs do Rio Madeira foi utilizado procedimento semelhante. Foram contratados consultores internacionais que elaboraram parecer a respeito dos sedimentos do Rio, pois havia preocupação de que devido ao grande volume presente no Rio comprometesse a operação das turbinas.

${ }^{39}$ Como apresentado na introdução do presente texto, utilizamos como estudo de caso da nossa reflexão o processo de licenciamento da UHE Tijuco Alto. Por conta disso sempre que ajudar a clarear nossas reflexões faremos menção ao referido processo que será melhor discutido no próximo capítulo. Faremos referência a outros empreendimentos sempre que for ajudar na compreensão de nossa exposição.
} 
Uma situação no mínimo curiosa, uma vez que, em tese, os estudos ambientais são complexos, e demandam pesquisa de campo, em fontes secundárias e muitas vezes até a formulação de dados primários.

\begin{tabular}{|c|c|c|c|c|c|c|c|}
\hline $\begin{array}{l}\text { Fases do } \\
\text { licenciamento }\end{array}$ & $\begin{array}{l}\text { Envio do } \\
\text { TR pelo } \\
\text { IBAMA } \\
\text { ao empre- } \\
\text { endedor } \\
S=20\end{array}$ & $\begin{array}{c}\text { Até a } \\
\text { entrega } \\
\text { do EIA- } \\
\text { RIMA } \\
\text { ao IBAMA } \\
\mathrm{S}=13\end{array}$ & $\begin{array}{c}\text { Até a } \\
\text { última } \\
\text { Audiência } \\
\text { Pública } \\
\mathrm{S}=12\end{array}$ & $\begin{array}{c}\text { Até a } \\
\text { emissão } \\
\text { da LP } \\
S=11\end{array}$ & $\begin{array}{l}\text { Até o } \\
\text { empreen- } \\
\text { dedor } \\
\text { requerer } \\
\text { LI } \\
S=13\end{array}$ & $\begin{array}{c}\text { Até o } \\
\text { IBAMA } \\
\text { emitir LI } \\
S=12\end{array}$ & $\begin{array}{c}\text { Até a } \\
\text { emissão } \\
\text { da Lo } \\
\mathrm{S}=11\end{array}$ \\
\hline $\begin{array}{l}\text { Média (dias) } \\
\text { Acumulada }\end{array}$ & $\begin{array}{l}394 \\
394\end{array}$ & $\begin{array}{l}219 \\
613\end{array}$ & $\begin{array}{l}263 \\
876\end{array}$ & $\begin{array}{r}82 \\
958\end{array}$ & $\begin{array}{c}145 \\
1.103\end{array}$ & $\begin{array}{c}132 \\
1.235\end{array}$ & $\begin{array}{l}1.100 \\
2.335\end{array}$ \\
\hline $\begin{array}{l}\text { DP (dos dias } \\
\text { acumulados) }\end{array}$ & 156 & 273 & 395 & 538 & 458 & 486 & 515 \\
\hline $\begin{array}{l}\text { Média (anos) } \\
\text { Acumulada }\end{array}$ & $\begin{array}{l}1,1 \\
1,1\end{array}$ & $\begin{array}{l}0,6 \\
1,7\end{array}$ & $\begin{array}{l}0,7 \\
2,4\end{array}$ & $\begin{array}{l}0,3 \\
2,7\end{array}$ & $\begin{array}{l}0,4 \\
3,1\end{array}$ & $\begin{array}{l}0,4 \\
3,4\end{array}$ & $\begin{array}{l}3,1 \\
6,5\end{array}$ \\
\hline $\begin{array}{l}\text { DP (dos anos } \\
\text { acumulados) }\end{array}$ & 0,4 & 0,8 & 1,2 & 1,5 & 1,3 & 1,4 & 1,4 \\
\hline
\end{tabular}

DP = Desvio Padrão; TR = Termo de Referência; LP = Licença Prévia; LI = Licença de Instalação;

LO = Licença de Operação; $\mathrm{S}=$ Tamanho da Amostra

Fonte: Banco Mundial, p. 62

A demora nas fases iniciais do processo quando da elaboração do Termo de Referência - TR (394 dias) e emissão da Licença Prévia - LP (958 dias) com intervalo relativamente menor entre o envio do TR e a entrega do EIA no IBAMA (219 dias); tempo menor do que os 345 que se leva entre entrega do EIA e a emissão da LP, tem explicações que remontam a características estruturais do sistema como um todo.

A primeira característica sistêmica exposta com os dados acima e que interfere para esse quadro é a falta de um quadro técnico no IBAMA em quantidade à altura da missão do órgão. O pouco número de servidores acarreta equipes pequenas sem a multidisciplinaridade que os processos exigem ${ }^{40}$ e que são obrigadas a tratar de assuntos que muitas vezes fogem à competência do grupo.

Houve esforço da gestão da Ministra Marina Silva no sentido de dotar o sistema de licenciamento de melhores condições de trabalho. Em cinco anos, o quadro de analistas concursados do IBAMA saltou de 8 para 149 servidores $^{41}$, e o número total de analistas mais que dobrou, eram 78 pessoas em 2002 e passaram a ser $180 \mathrm{em} 2007$.

\footnotetext{
${ }^{40}$ Uma das recomendações do estudo do Banco Mundial é a contratação de profissionais com formação em ciências humanas, pois a quantidade de analistas com esse perfil tem sido aquém do necessário.

${ }^{41}$ Além do aumento do quadro de analistas concursados, foram feitas reestruturações internas na Diretoria de Licenciamento - a Diretoria de Licenciamento e Qualidade Ambiental - DILIQ foi dividida em Diretoria de Qualidade Ambiental e Diretoria de Licenciamento Ambiental, dentro da qual foram criadas três coordenações gerais: a Coordenação de Petróleo e Gás; Coordenação de Energia; e Coordenação de Transporte, Mineração e Obras Civis. Antes, não havia equipes fixas para cada tipologia de empreendimento.
} 


\begin{tabular}{|l|c|c|c|c|c|c|}
\hline Quadro 06 - Novas contratações do IBAMA ano a ano \\
\hline $\begin{array}{l}\text { QUADRO DE } \\
\text { PESSOAL }\end{array}$ & \multicolumn{7}{|c|}{ ANO } \\
\cline { 2 - 7 } & $\mathbf{2 0 0 2}$ & $\mathbf{2 0 0 3}$ & $\mathbf{2 0 0 4}$ & $\mathbf{2 0 0 5}$ & $\mathbf{2 0 0 6}$ & $\mathbf{2 0 0 7}$ \\
\hline $\begin{array}{l}\text { Analista } \\
\text { Ambiental I } \\
\text { Servidor }\end{array}$ & 8 & 62 & 79 & 115 & 120 & 149 \\
\hline $\begin{array}{l}\text { Consultor } \\
\text { Técnico PNUD }\end{array}$ & 70 & 68 & 54 & 35 & 16 & 17 \\
\hline Temporário & 0 & 0 & 45 & 41 & 18 & 14 \\
\hline Total & 78 & 130 & 178 & 191 & 154 & 180 \\
\hline
\end{tabular}

Fonte: O Licenciamento em números. Site do Ibama em 2/11/08 às 12:49 WWW.ibama.gov.br/wp-content/files/ibama-em-numeros.pdf

Com o quadro de servidores concursados, o sistema se fortalece na medida em que abre a possibilidade para formação continuada da equipe, conformação de memória institucional e aprimoramento da expertise do quadro de analistas. No modelo anterior de contratações precárias, após dois anos, o quadro de consultores tinha que ser renovado, o que dificultava uma política permanente de valorização e capacitação da equipe técnica.

\begin{tabular}{|l|l|c|c|c|c|c|c|c|c|c|}
\hline \multicolumn{10}{|l|}{ Quadro 07 - Quantidades de Licenças Emitidas pelo IBAMA ano a ano } \\
\hline $\begin{array}{l}\text { Tipo de } \\
\text { Licença }\end{array}$ & \multicolumn{10}{|c|}{ Quantidade } \\
\cline { 2 - 13 } & 1998 & 1999 & $\mathbf{2 0 0 0}$ & $\mathbf{2 0 0 1}$ & $\mathbf{2 0 0 2}$ & $\mathbf{2 0 0 3}$ & $\mathbf{2 0 0 4}$ & $\mathbf{2 0 0 5}$ & $\mathbf{2 0 0 6}$ & $\mathbf{2 0 0 7}$ \\
\hline LP & 13 & 8 & 9 & 20 & 23 & 6 & 22 & 23 & 17 & 18 \\
\hline LO & 15 & 32 & 31 & 41 & 61 & 49 & 38 & 69 & 66 & 103 \\
\hline LI & 21 & 20 & 19 & 24 & 45 & 14 & 49 & 45 & 60 & 63 \\
\hline $\begin{array}{l}\text { Outras } \\
\text { Licenças }\end{array}$ & 38 & 52 & 80 & 63 & 72 & 49 & 127 & 156 & 167 & 183 \\
\hline
\end{tabular}

Fonte: O Licenciamento em números. Site do Ibama em 22/11/08 às 12:49 WWW.ibama.gov.br/wp-content/files/ibama-em-numeros.pdf

Mesmo com o aumento do número de analistas ambientais, entre os anos de 2002 e 2007, conforme os quadros acima, a média servidor por licença aprovada teve pequena queda de 2,57 em 2002 para 2,03 projetos acompanhados por cada um em 2007. Embora tenha havido esforço em aumentar e melhorar as condições de contratação do quadro técnico, ainda há carência de pessoal.

A contribuição do Banco Mundial à reflexão do licenciamento ambiental de hidrelétricas no país constatou que há carência de profissionais com formação na área social no órgão de licenciamento ambiental. 
Segundo o Banco Mundial, a falta de um corpo técnico com qualificação adequada ${ }^{42}$ contamina todo o processo. O exíguo quadro técnico de analistas ambientais demanda que a mesma equipe cuide de mais de um empreendimento, o que impossibilita, por exemplo, idas a campo freqüentes, ou em momentos nevrálgicos do processo, a fim de conhecer e entender melhor a dinâmica social, econômica, física e biológica da região onde se quer instalar o empreendimento.

A falta de um corpo técnico grande e com formação diversificada contribui para que os TRs em algumas situações sejam frágeis, o que demanda pedidos de complementos quando o EIA já foi pronto e entregue.

Esse quadro, de certa forma, torna a equipe de analistas do IBAMA dependente dos consultores que preparam os EIAs, uma vez que os profissionais contratados pelo empreendedor dominam temas que a equipe de analistas pouco conhece, ou as vezes desconhece; e a demanda de trabalho não permite que possam se aprofundar em tentar conhecer ou melhorar conhecimento a respeito de determinada situação.

O tempo aquém do suficiente que cada equipe de analistas dedica a cada projeto em análise interfere também nas idas a campo dos servidores do IBAMA de duas formas:

1. Pouco tempo para cada visita de campo ${ }^{43}$,

2. Em função do pouco tempo, os analistas ficam mais sujeitos à programação feita pela equipe de consultores do EIA, que têm domínio da região e das características do projeto e acabam por ter o controle sobre aquilo que será vistoriado pelos analistas.

A falta de estrutura adequada do IBAMA e a legislação contribuem para que o empreendedor tenha controle financeiro, técnico e político de praticamente todo o processo de licenciamento. A resolução Conama 09/87 estabelece como obrigatoriedade do empreendedor a realização dos estudos de im-

\footnotetext{
42 Importante deixar claro que essa afirmação não é uma crítica aos servidores do IBAMA, que ao contrário, trabalham sem condições adequadas e ainda assim cumprem de maneira honrosa suas obrigações. A crítica tenta pontuar que falta gente e com formações diferenciadas nas equipes técnicas de licenciamento. O local do problema não são os servidores individualmente e sim a falta de uma política de Estado que dote o IBAMA de capacidade a altura da sua missão.

${ }^{43}$ A visita a campo da equipe técnica que analisou o processo de Tijuco Alto foi feita em 4 dias no Vale do Ribeira antes da definição do TR. Dois desses dias foram utilizados para deslocar a equipe de São Paulo para a região e voltar. A equipe foi conduzida pelos consultores da CNEC, que em dois dias apresentaram a região aos analistas.
} 
pacto ambiental e audiências públicas, pressupondo, é claro, que os estudos serão revisados e analisados pela equipe técnica do órgão licenciador.

Não há tempo, nem condições administrativas que contribuam para que o corpo técnico do IBAMA possa buscar fora do órgão conhecimento quando necessário. Demandas geradas por situações novas em relação à experiência acumulada no órgão ou com alto grau de complexidade podem ficar sem solução adequada. Quando isto ocorre, o procedimento tem sido solicitar ao empreendedor que esclareça esta ou aquela dúvida ou até mesmo que formule juízo técnico a respeito do tema ${ }^{44}$.

As condições de trabalho dos analistas são precárias e insuficientes ${ }^{45}$ e sem dúvida aí está uma das razões para a baixa qualidade dos Estudos de Impacto Ambiental. O relatório publicado pelo Banco Mundial afirma que nos quatro estudos de caso houve a necessidade do órgão licenciador solicitar complementações ao estudo.

A falta de condições adequadas à análise do processo se manifesta na qualidade dos Estudos de Impacto Ambiental. Assim, os estudos são feitos sabendo os empreendedores das limitações da equipe técnica do IBAMA, e há uma apropriação dessa condição uma vez que durante todo o processo de licenciamento há relação estreita entre equipe técnica do IBAMA e consultores contratados para elaboração do EIA.

A discussão técnica entre analistas e consultores em torno da constituição do EIA é permeada o tempo todo também por uma disputa dos rumos do estudo. No Estudo de Impacto Ambiental de Tijuco Alto, a $\mathrm{CNEC}^{46}$ apresentou um parecer realizado por um de seus consultores que concluía não haver impacto da UHE na região estuarina. No entanto, o coletivo de educadores do lagamar, apresentou outro estudo, que concluía exatamente o contrário. Acabou prevalecendo a posição defendida pela CNEC.

\footnotetext{
${ }^{44}$ No caso da UHE Tijuco Alto, no primeiro licenciamento, o IBAMA solicitou que os estudos fossem até a foz do Rio. No segundo processo de licenciamento, o TR não previu estudos até a foz do Rio Ribeira. Os questionamentos a respeito da necessidade ou não de estudos até a região estuarina que poderia ser impactada devido a alteração da cunha salina foram respondidos pelos consultores contratados pelo empreendedor e não pelo IBAMA, quem deveria poder dizer porque mudou o critério em relação a extensão do estudos. Nas audiências, quando confrontados com esse questionamento, os servidores da instituição responderam que as decisões do IBAMA eram tomadas com base em informações técnicas disponíveis.

${ }^{45} \mathrm{E}$ sujeitas a constante pressão política, ainda que publicamente ninguém assuma.

${ }^{46}$ A CNEC é a empresa de consultoria contratada pela CBA, para realizar o EIA da UHE Tijuco Alto.
} 
O mito do licenciamento ambiental como obstáculo burocrático a ser removido pelo empreendedor o leva a minimizar sistematicamente sua importância face ao interesse econômico do empreendimento. Isso explica, em parte, a baixa qualidade dos estudos de impacto ambiental e o nível técnico do diálogo mantido durante o licenciamento entre a equipe de técnicos vinculados ao empreendimento e os órgãos licenciadores (BANCO MUNDIAL, 2008, p. 49).

Durante o licenciamento de Tijuco Alto foram realizadas inúmeras reuniões técnicas entre as duas equipes para a elaboração do TR, visita a campo da equipe de analistas ${ }^{47}$, reuniões para discutir pontos específicos do EIA que foi sendo apresentado em partes.

Os problemas relacionados aos estudos de impacto ambiental são recorrentes e foram sistematizados no estudo do Banco Mundial a partir de publicação realizada pela Escola Superior do Ministério Público da União.

O problema da qualidade técnica dos EIA-RIMAs foi identificado por todos os atores do processo de licenciamento ambiental. As análises deste estudo confirmaram esse entendimento e corroboram trabalho preparado pela $4^{\text {a }}$ Câmara de Coordenação do Ministério Público Federal (BANCO MUNDIAL, 2008, p. 81-82).

A baixa qualidade dos estudos apresentados nos processos de licenciamento interfere negativamente nos prazos de concessão das licenças, pois demanda que o órgão licenciador solicite complementações e abre precedente para a intervenção do MP e a judicialização do processo.

Estas constatações demonstram que visões maniqueístas dos problemas que envolvem o licenciamento ambiental se equivocam por não compreender o caráter sistêmico do processo de licenciamento ambiental.

A solução dos problemas que dificultam a boa aplicação do instrumento do licenciamento, passa pela percepção das responsabilidades que cabe a cada um dos atores envolvidos nos processos. Nesse sentido, o conceito de "imaginação sociológica" se constitui em instrumento valioso, uma vez que busca entender as relações sociais, políticas e econômicas sob o processo histórico que as conformaram, mas também em relação às biografias que compõem determinada percepção da

\footnotetext{
${ }^{47}$ Foram realizadas duas visitas de campo da equipe do IBAMA ao Vale do Ribeira. Em ambas, a CNEC ciceroneou os analistas, que não ficaram mais do que 4 dias durante suas vistorias.
} 
realidade. Recorre-se à leitura de Wright Mills (1975) da "imaginação sociológica" ou a capaci-

dade de percebermos as relações, às vezes ocultas, que animam as complexas interações sociais

com suas vicissitudes e problemas.

\begin{tabular}{|c|c|}
\hline \multicolumn{2}{|c|}{ Quadro 08 - Deficiências Encontradas em EIA`s } \\
\hline Tema & Deficiências \\
\hline $\begin{array}{l}\text { Atendimento ao } \\
\text { Termo de Referência }\end{array}$ & $\begin{array}{l}\text { - Ausência de pesquisas e análises adequadas } \\
\text { - Requerimentos passados pelo órgão licenciador na fase posterior do } \\
\text { empreendimento }\end{array}$ \\
\hline $\begin{array}{l}\text { Objetivo do } \\
\text { empreendimento }\end{array}$ & $\begin{array}{l}\text { Omissão, ou registro superficial, da relação do projeto específico } \\
\text { com o conjunto da obra ao qual se filia } \\
\text { Apenas parte do empreendimento é proposta para análise }\end{array}$ \\
\hline $\begin{array}{l}\text { Estudo de alternativas } \\
\text { tecnológicas e } \\
\text { locacionais }\end{array}$ & $\begin{array}{l}\text { Ausência de proposição de alternativas } \\
\text { - Proposta de alternativas reconhecidamente inferiores à selecionada } \\
\text { no EIA } \\
\text { - Prevalência dos aspectos econômicos sobre os ambientais na } \\
\text { escolha de alternativas } \\
\text { - Comparação de alternativas a partir de base de conhecimentos } \\
\text { diferenciada }\end{array}$ \\
\hline $\begin{array}{l}\text { Delimitação das áreas } \\
\text { de influência }\end{array}$ & $\begin{array}{l}\text { - Desconsideração da bacia hidrográfica } \\
\text { - Delimitação desconhecendo a real situação ambiental e social da área }\end{array}$ \\
\hline $\begin{array}{l}\text { Diagnóstico } \\
\text { ambiental }\end{array}$ & $\begin{array}{l}\text { Prazos insuficientes para a realização de pesquisas de campo } \\
\text { - Caracterização da área baseada predominantemente em dados } \\
\text { secundários } \\
\text { - Ausência ou insuficiência de informações sobre a metodologia } \\
\text { utilizada } \\
\text { - Falta de integração dos dados de estudos específicos }\end{array}$ \\
\hline $\begin{array}{l}\text { Identificação } \\
\text { caracterização e } \\
\text { análise de impactos }\end{array}$ & $\begin{array}{l}\text { - Não-identificação ou identificação parcial de determinados impactos } \\
\text { - Identificação de impactos genéricos e impactos mutuamente } \\
\text { excludentes } \\
\text { - Não-utilização ou subutilização de dados dos diagnósticos } \\
\text { Desconsideração ou subestimação de impactos cumulativos ou } \\
\text { sinérgicos } \\
\text { - Tendência à minimização ou subestimação de impactos negativos e a } \\
\text { supervalorização de impactos positivos }\end{array}$ \\
\hline $\begin{array}{l}\text { Mitigação e } \\
\text { compensação de } \\
\text { impactos }\end{array}$ & $\begin{array}{l}\text { - Proposta de medidas que não mitigam o impacto } \\
\text { - Identificação de medidas pouco detalhadas } \\
\text { - Obrigações legais apresentadas como medidas mitigadoras } \\
\text { - Ausência de avaliação de medidas mitigadoras } \\
\text { - Reassentamento involuntário de populações com base em } \\
\text { diagnósticos inadequados } \\
\text { - Não-incorporação das propostas dos grupos sociais afetados } \\
\text { - Proposta de criação de unidade de conservação de categoria } \\
\text { incompatível com a lei } \\
\text { - Ausência de informações detalhadas acerca dos recursos financeiros } \\
\text { destinados aos programas e projetos ambientais }\end{array}$ \\
\hline $\begin{array}{l}\text { Programas de } \\
\text { acompanhamento } \\
\text { e monitoramento } \\
\text { ambiental }\end{array}$ & $\begin{array}{l}\text { Erros conceituais na indicação de monitoramento } \\
\text { Ausência de programa de monitoramento de impactos } \\
\text { específicos/programa insuficiente } \\
\text { Estipulação de prazos de monitoramento incompatíveis com a época } \\
\text { de ocorrência de impactos }\end{array}$ \\
\hline
\end{tabular}

Fonte: Deficiências em Estudo de Impacto Ambiental Síntese de uma Experiência, Escola Superior do Ministério Público da União, 2004 


\subsubsection{Conflitos Socioambientais - Licenciamento Ambiental, Política Pública ou Fórum de Discussão Política}

O relatório publicado pelo Banco Mundial, ao apresentar os estudos de caso das quatro hidrelétricas conclui que o processo de licenciamento contribuiu definitivamente com a melhoria da qualidade ambiental dos empreendimentos (BANCO MUNDIAL, 2008, p.75).

No entanto, identifica que o ponto central do processo de licenciamento no país são as questões relacionadas ao impacto social causado pelos empreendimentos. O estudo reproduz dados de três pesquisas que tentaram estimar o percentual dos custos socioambientais frente ao total de gastos do empreendimento.

O percentual de gastos socioambientais variou entre $10 \%$ e $22 \%$ para as hidrelétricas mais antigas e entre $2 \%$ e $37 \%$ para as mais recentes. Embora haja divergência em torno do percentual gasto com a mitigação dos impactos

"Esses três estudos observam a preponderância - em torno de $75 \%$ - dos gastos associados à compra de terrenos, infra-estrutura e realocação de população, nenhum deles realmente ambientais per se" (BANCO MUNDIAL, 2008, p.55).

A questão social é tratada de maneira inovadora pelo relatório. Pois, ao discutir o licenciamento de hidrelétricas sob a perspectiva social, os consultores do Banco Mundial deram legitimidade às duas principais posições ${ }^{48}$ em disputa, relativas ao trato das questões sociais:

1. O empreendimento deve buscar se inserir em uma lógica de desenvolvimento regional - O empreendedor deve construir em torno de seu projeto articulações institucionais capazes de transformar a UHE em um catalisador de políticas públicas e indutor do desenvolvimento regional. Essa é uma reivindicação antiga do movimento social e que teve acolhimento nos documentos do setor elétrico na década de 90;

2. Os empreendimentos são chamados a arcar com iniciativas que não lhe dizem respeito, trazendo para o âmbito do licenciamento problemas e custos que nada têm a ver com as hidrelétricas - Esse posicionamento tem sido reiteradas vezes repetido pelo setor

\footnotetext{
${ }^{48}$ Quase antagônicas, para variar
} 
hidrelétrico em tom de reclamação, uma vez que os empresários são chamados a arcar com custos externos ao seu negócio.

Embora possam parecer até contraditórias entre si, essas duas posições são apresentadas como legítimas, uma vez que são estruturantes do discurso e do posicionamento dos principais atores.

Em relação à posição de que as hidrelétricas precisam dialogar com o desejo de desenvolvimento local a partir da construção de pontes com os setores que se articulam localmente, o estudo apresenta o conceito de viabilidade socioambiental, ou a necessidade de que os estudos de inventário e de viabilidade

- incorporem variáveis que expressem o amplo espectro de impactos sociais e ambientais associados aos empreendimentos;

- satisfaçam a um conjunto de restrições tidas como relevantes pelo setor e pela sociedade no campo socioambiental (como, por exemplo, a não destruição de certos valores culturais ou de áreas de especial importância ecológica);

- indiquem uma geração de benefícios líquidos satisfatória (BANCO MUNDIAL, 2008, p. 16).

A viabilidade socioambiental é construída sob uma lógica inversa à que vigorou durante o período da ditadura, quando os empreendimentos só levavam em conta os interesses internos de expansão. De acordo com essa visão, a expansão do sistema elétrico reflete seu compromisso com o público consumidor, mas também com a parcela de cidadãos que terão suas vidas impactadas por essa expansão.

O documento do Banco Mundial, embora apresente a idéia que passou a vigorar no setor elétrico nos anos 90, atribui mais peso à segunda posição, qual seja, a de que o setor tem sido chamado a responsabilizar-se por situações que lhe são externas e isso acontece sobretudo por conta da inércia do sistema de gestão ambiental que pouco se modificou nos últimos anos, enquanto o setor elétrico passou por muitas modificações.

"A ausência de contínua atualização das normas do licenciamento ambiental permitiu a absorção de encargos e conflitos de natureza política e social, que tornam a implantação de empreendimentos de infra-estrutura cada vez mais complexa. Além disso, a característica pontual e isolada da atual legislação de licenciamento ambiental e a ausência de contextualização estratégica fazem com que os empreendimentos do setor de energia enfrentem incertezas e questionamentos que já deveriam ter sido respondidos antes do início dos processos de licenciamento ambiental de projetos específicos. Essa característica de isolamento resulta na obrigação de cada 
empreendedor de equacionar demandas não derivadas do potencial impacto ambiental direto do empreendimento proposto. São exemplos desse tipo de demanda os investimentos nos municípios para construção ou asfaltamento de rodovias em áreas distantes do empreendimento e ações sociais voltadas para as populações não atingidas pelo empreendimento, como cestas básicas para moradores carentes, instalação de postos de saúde e escolas, entre outras. A resolução de conflitos de ordem social pré-existentes não deveria ser atribuída, em sua totalidade, ao empreendedor, uma vez que esses conflitos deveriam ser resolvidos pela Administração Pública, por meios próprios, independentemente do processo de licenciamento ambiental" (BANCO MUNDIAL, 2008, 36).

A tese central da afirmação de que "incertezas e questionamentos que já deveriam ter sido respondidos antes do início dos processos de licenciamento ambiental de projetos específicos", repousa sobre a reflexão de que é preciso constituir outros instrumentos de gestão e ou planejamento que possam cooperar com o licenciamento ambiental.

Tem sido através do licenciamento ambiental, principalmente nas audiências públicas, que uma série de discussões relacionadas a assuntos diversos aos empreendimentos têm sido pautadas por autoridades políticas, normalmente a fim de promover-se, e pelo movimento social.

Não é raro que nas audiências públicas aflorem temas como o modelo de desenvolvimento do país, perfil da matriz energética, vocação econômica da região entre outras discussões que têm mérito e devem ser discutidas de forma transparente e democrática. Entretanto, não cabe serem discutidas no âmbito das APs que têm como objeto a apresentação e discussão do EIA relativos às UHEs em processo de licenciamento.

A avaliação ambiental estratégica - AAE é apresentada pela publicação como uma solução que faria antecipar conflitos de modo a dar mais previsibilidade ao processo como um todo à medida que estudos antecipados demonstrariam potencialidades e as suscetibilidades dos aproveitamentos hidrelétricos que seriam levados em conta no momento dos seus planejamentos.

Por se tratar de um instrumento de planejamento, a AAE teria o papel de ir além das questões eminentemente socioambientais relacionadas aos projetos; e a partir de um processo de interação dos atores sociais proceder discussões que são totalmente legítimas, mas que tendem a ter melhores resultados do ponto de vista de suas consequiências, se debatidas em fóruns adequados, já 
que não cabem serem discutidas no âmbito do licenciamento ambiental, sobretudo no momento das audiências públicas.

Debates a respeito da matriz energética brasileira e da conveniência de mantermos as hidrelétricas como principal fonte de geração de energia ou da conveniência ou não de dispormos de determinadas áreas para a construção de UHEs cabem na AAE.

O relatório do Banco Mundial afirma que a variável ambiental nem sempre tem sido incorporada no planejamento dos empreendimentos que, normalmente, têm sua localização decidida em função das variáveis econômica e técnica e a variável ambiental é secundarizada.

Percebe-se que as alternativas locacionais não são frequientemente discutidas quando do processo de decisão de implantação dos projetos. Normalmente, o órgão do setor elétrico define o local do empreendimento com base em fatores principalmente econômicos e depois busca justificar ambientalmente sua localização no processo de licenciamento, o que consiste em mais uma demonstração de que o vetor ambiental não é ainda fator integrante da concepção dos empreendimentos como deveria (BANCO MUNDIAL, 2008, p.50).

No contexto de busca das soluções para os problemas enfrentados pelo licenciamento ambiental no país, a Avaliação Ambiental Estratégica e as Avaliações Ambientais Integradas das bacias hidrográficas, que já estão sendo realizadas pela EPE, poderão contribuir para que os projetos de construção de novas hidrelétricas incorporem a variável ambiental como variável estratégica do empreendimento.

\subsection{HIDRELÉTRICAS NO BRASIL-A PAUTA DOS ATINGIDOS}

Um dos aspectos mais interessantes do relatório do Banco Mundial é o de um único texto dar legitimidade a pontos de vista conflitantes. A força do documento reside exatamente no fato de que ao integrar os diferentes pontos de vista que disputam os rumos do licenciamento ambiental no país, criou-se a possibilidade de fazer avançar o diálogo. Isto ocorre, na medida em que o trabalho do organismo internacional reconheceu como válidas posições de todos os atores, o que estimula o diálogo em patamar diferente do que vigorou até o momento de sua publicação. 
O debate proposto pelo MAB em relação à construção de hidrelétricas no Brasil, sobretudo na interação com o setor empreendedor, até a publicação do relatório, sempre teve o reconhecimento da figura do atingido como um limite ao debate.

O estudo do Banco Mundial incorporou os resultados do Grupo de Trabalho Interministerial Atingidos por Barragens, e afirma que há convergência entre a experiência do banco no trato da questão dos reassentados e o resultado da discussão do governo a respeito da pauta do MAB.

O relatório vai além e apresenta as premissas ${ }^{49}$ do organismo em relação à pauta prioritária dos “atingidos por barragens" no Brasil.

O reassentamento involuntário pode provocar danos a longo prazo, empobrecimento e danos ambientais, exceto se medidas apropriadas forem cuidadosamente planejadas e implementadas. Por tais razões, os objetivos genéricos da política do Banco referentes ao reassentamento involuntário são os seguintes:

(a) O reassentamento involuntário deve ser evitado sempre que possível, ou então minimizado, explorando-se todas as alternativas viáveis para o design do projeto.

(b) Quando não for possível evitar o reassentamento involuntário, as atividades de reassentamento deverão ser concebidas e executadas como programas de desenvolvimento sustentável, fornecendo-se recursos para investimentos suficientes para que as pessoas deslocadas pelo projeto possam participar dos benefícios providos pelo mesmo projeto. Pessoas deslocadas deverão ser consultadas extensivamente e deverão ter oportunidades para participar do planejamento e implementação de programas de reassentamento.

(c) Pessoas deslocadas deverão ser assistidas nos seus esforços para melhorarem o modo e as condições de vida, ou pelo menos para restaurar, em termos reais, as condições previamente ao reassentamento ou ao início da implementação do projeto, prevalecendo o que for mais elevado" (BANCO MUNDIAL, 2008, p. 48).

O reconhecimento da pauta do Movimento dos Atingidos por Barragens manifesta pelo estudo é bastante significativa. Ajuda a pautar o assunto nas discussões a respeito da expansão do setor elétrico, assim como, confere legitimidade às populações atingidas pelos empreendimentos hidrelétricos.

Anterior ao estudo em debate, o movimento já havia obtido uma vitória significativa quando o governo federal, por iniciativa própria, criou o GTI Atingidos por Barragens. Um marco no debate sobre os

\footnotetext{
${ }^{49}$ A posição do Banco Mundial a respeito dos reassentados está expressa no documento intitulado "Banco Mundial/ Política Operacional 4.12 Reassentamento Involuntário". O volume dos anexos do trabalho sobre o licenciamento de hidrelétricas contém o referido documento.
} 
impactos socioeconômicos oriundos da construção de hidrelétricas no país, pois, "pela primeira vez, na história do setor elétrico, o tema foi incluído na agenda oficial do Governo Federal, por meio de decreto presidencial” (PRESIDÊNCIA DA REPÚBLICA, 2004, p. 49).

O grupo teve coordenação da Casa Civil da Presidência da República, e foi composto por mais outros quatorze ministérios ${ }^{50}$. O objetivo do GTI foi "analisar as demandas apresentadas pela sociedade civil organizada, representativa dos atingidos por barragens, formular diagnóstico e elaborar propostas para o equacionamento dos problemas identificados" (PRESIDÊNCIA DA REPÚBLICA, 2004, p. 7).

O GTI produziu um relatório final no qual o governo brasileiro reconhece uma série de reivindicações históricas dos atingidos que foram materializadas pela entrega do documento "Plataforma do Movimento de Atingidos por Barragens - Ações Prioritárias”. O documento entregue pelo MAB contou com 11 pontos que foram discutidos e analisados pelo GTI que

realizou um ciclo de audiências com especialistas no assunto e com os principais atores envolvidos na questão, iniciado com a identificação dos pleitos dos atingidos por barragens e, na seqüência, com exposições de consultores/especialistas de universidades, órgãos públicos, agentes financeiros e de concessionária de energia elétrica (PRESIDÊNCIA DA REPÚBLICA, 2004, p. 8).

Em seu relatório final, o GTI reconheceu a existência dos problemas pautados pelo MAB e os dividiu em duas classes:

1. Problemas centrais relacionados ao licenciamento;

2. Problemas sociais, fruto de lacunas dos dispositivos legais ou descumprimentos de outros já existentes e que geram impactos sociais.

Para cada um dos problemas identificados, o GTI elencou propostas e os órgãos responsáveis, pelas mesmas sistematizados no quadro 9 da próxima página.

\footnotetext{
${ }^{50}$ O GTI foi composto pela Casa Civil da Presidência da República (Coordenação), Secretaria-Geral da Presidência da República, Gabinete de Segurança Institucional da Presidência da República, Ministério da Justiça, Ministério da Fazenda, Ministério da Agricultura, Pecuária e Abastecimento, Ministério da Educação, Ministério do Trabalho e Emprego, Ministério de Minas e Energia, Ministério do Planejamento, Orçamento e Gestão, Ministério do Meio Ambiente, Ministério da Integração Nacional, Ministério do Desenvolvimento Agrário, Ministério Extraordinário da Segurança Alimentar e Combate à Fome, e a Secretaria Especial de Aqüicultura e Pesca. O GTI realizou 35 reuniões entre 09/2003 e 05/2004.
} 


\begin{tabular}{|c|c|c|}
\hline \multicolumn{3}{|c|}{ Quadro 09 - Relatório Final GTI Atingidos } \\
\hline $\begin{array}{l}\text { PROBLEMAS } \\
\text { IDENTIFICADOS }\end{array}$ & PROPOSTAS & $\begin{array}{l}\text { ÓRGÃOS } \\
\text { RESPONSÁVEIS }\end{array}$ \\
\hline $\begin{array}{l}\text { Dívida social do setor } \\
\text { hidrelétrico com os } \\
\text { atingidos }\end{array}$ & \multirow[t]{2}{*}{$\begin{array}{l}\text { Continuidade das ações desenvolvidas pela } \\
\text { Mesa de negociações Governo/Atingidos }\end{array}$} & $\begin{array}{l}\text { Mesa de Negociações da } \\
\text { SG/PR, MDA, MDS e } \\
\text { MME }\end{array}$ \\
\hline $\begin{array}{l}\text { Necessidade de ações } \\
\text { emergenciais (cestas básicas } \\
\text { e crédito agrícola) para } \\
\text { atingidos desassistidos }\end{array}$ & & $\begin{array}{l}\text { Mesa de Negociações } \\
\text { SG/PR, MDS, MDA, MME } \\
\text { (articulação com ANEEL, } \\
\text { Eletrobrás, BNDES, pre- } \\
\text { feituras, Secs. Ests. e } \\
\text { entidades do Terceiro Setor) }\end{array}$ \\
\hline \multirow[t]{2}{*}{$\begin{array}{l}\text { Falta de critério para } \\
\text { identificação de atingidos } \\
\text { por barragens }\end{array}$} & $\begin{array}{l}\text { Inclusão obrigatória, no conceito de atingidos, } \\
\text { de grupos especiais e de pessoas que vivem de } \\
\text { atividades pesqueiras ou agropecuárias nas } \\
\text { áreas inundadas pelos reservatórios; }\end{array}$ & \multirow[t]{2}{*}{$\begin{array}{l}\text { MME, MI, MDA, MMA, } \\
\text { MDS }\end{array}$} \\
\hline & $\begin{array}{l}\text { Criação de condições para inclusão dos } \\
\text { demais grupos que se julguem atingidos }\end{array}$ & \\
\hline $\begin{array}{l}\text { Insuficiência do conteúdo } \\
\text { social no EIA/RIMA }\end{array}$ & $\begin{array}{l}\text { Fortalecimento dos estudos sociais no } \\
\text { EIA/RIMA }\end{array}$ & $\begin{array}{l}\text { MME/EPE, Ibama, CMSE } \\
\text { e MI e OEMA }\end{array}$ \\
\hline $\begin{array}{l}\text { Precariedade do cadastro } \\
\text { socioeconômico }\end{array}$ & $\begin{array}{l}\text { Aperfeiçoamento de critérios e procedimentos } \\
\text { para elaboração do cadastro socioeconômico } \\
\text { na fase de Estudos de Inventário }\end{array}$ & $\begin{array}{l}\text { MME/EPE, Ibama, CMSE, } \\
\text { ANEEL e MI }\end{array}$ \\
\hline $\begin{array}{l}\text { Falta de informações às } \\
\text { população afetada }\end{array}$ & $\begin{array}{l}\text { Implementação de programas informativos e de } \\
\text { relacionamento com a comunidade atingida }\end{array}$ & $\begin{array}{l}\text { MME/EPE, CMSE e } \\
\text { ANEEL }\end{array}$ \\
\hline $\begin{array}{l}\text { Fragilidade do processo de } \\
\text { negociação entre con- } \\
\text { cessionárias e atingidos }\end{array}$ & $\begin{array}{l}\text { Estímulo e criação de condições para } \\
\text { organização social dos atingidos e sua } \\
\text { representação perante as concessionárias }\end{array}$ & MME/EPE, MI e OEMA \\
\hline $\begin{array}{l}\text { Precariedade dos acordos } \\
\text { concessionárias/atingidos }\end{array}$ & $\begin{array}{l}\text { Facilitação do acordo entre as partes } \\
\text { envolvidas e sua posterior fiscalização }\end{array}$ & CMSE, Ibama e ANEEL \\
\hline $\begin{array}{l}\text { Incompatibilidade entre } \\
\text { cronogramas técnicos, físico- } \\
\text { financeiros e programas sociais }\end{array}$ & $\begin{array}{l}\text { Compatibilização dos cronogramas visando a } \\
\text { harmonização das etapas e a execução das } \\
\text { medidas sociais previstas }\end{array}$ & $\begin{array}{l}\text { MME/EPE e Órgão } \\
\text { Licenciamento Ambiental } \\
\text { até a obtenção da LP. }\end{array}$ \\
\hline $\begin{array}{l}\text { Falta de critérios para } \\
\text { reassentamento/indenização }\end{array}$ & $\begin{array}{l}\text { Estabelecimento de critério com base no } \\
\text { conceito de atingidos }\end{array}$ & MME, MI, MDA e MMA \\
\hline $\begin{array}{l}\text { Tratamento diferenciado } \\
\text { das questões sociais no } \\
\text { licenciamento ambiental }\end{array}$ & $\begin{array}{l}\text { Criação de GT propondo, ao Conama, a } \\
\text { uniformização de critérios nas esferas Federal } \\
\text { e estaduais }\end{array}$ & $\begin{array}{l}\text { Ministérios componentes } \\
\text { do GTI com assento no } \\
\text { Conama. }\end{array}$ \\
\hline $\begin{array}{l}\text { Participação insuficiente de } \\
\text { Estados e Municípios em } \\
\text { ações voltadas aos atingidos }\end{array}$ & $\begin{array}{l}\text { Direcionamento de parte das compensações } \\
\text { financeiras e royalties aos atingidos }\end{array}$ & MME/ANEEL \\
\hline $\begin{array}{l}\text { Ausência de condicionantes } \\
\text { sociais em financiamentos a } \\
\text { hidrelétricas }\end{array}$ & $\begin{array}{l}\text { Inclusão de condicionalidades sociais em } \\
\text { financiamentos do BNDES, BIRD e BID }\end{array}$ & $\begin{array}{l}\text { MME/EPE, MP/COFIEX } \\
\text { e MI }\end{array}$ \\
\hline \multirow{2}{*}{$\begin{array}{l}\text { Proibição ou cobrança de } \\
\text { taxas, por concessionárias, } \\
\text { por atividades pesqueiras }\end{array}$} & Coibição da prática de cobrança de taxas & ANAe SEAP/PR \\
\hline & $\begin{array}{l}\text { Ordenamento e estímulo às atividades } \\
\text { pesqueiras nos reservatórios }\end{array}$ & SEAP/PR \\
\hline \multirow[t]{2}{*}{$\begin{array}{l}\text { Direcionamento de ações } \\
\text { setoriais }\end{array}$} & $\begin{array}{l}\text { Programas de geração de emprego e renda, } \\
\text { qualificação e requalificação profissional e } \\
\text { Programa de Economia Solidária em } \\
\text { Desenvolvimento }\end{array}$ & MTE \\
\hline & $\begin{array}{l}\text { Ações voltadas ao restabelecimento de laços } \\
\text { sociais e readaptação das comunidades } \\
\text { remanejadas; ações educativas específicas; } \\
\text { educação energética e sanitária; repasses do } \\
\text { FUNDEF e do salário educação }\end{array}$ & MEC \\
\hline
\end{tabular}

Fonte: Relatório Final GTI Atingidos por Barragens 
Com base na lista de problemas identificados pelo GTI e reconhecidos em seu relatório, elaboramos o quadro abaixo propondo outra classificação para os problemas consensuados, que toma como referência onde tem origem a situação capaz de gerar problema social aos atingidos ${ }^{51}$.

\begin{tabular}{|c|c|}
\hline \multicolumn{2}{|c|}{ Quadro 10 - Problemas identificados } \\
\hline \multicolumn{2}{|r|}{ Relação Atingidos X Outros Atores } \\
\hline \multirow{5}{*}{$\begin{array}{l}\text { Dificuldades da } \\
\text { relação com o } \\
\text { empreendedor no } \\
\text { momento do EIA }\end{array}$} & 1. Inexistência de critério para identificação de atingidos por barragens; \\
\hline & 2. Insuficiência do conteúdo social na elaboração do EIA/RIMA; \\
\hline & 3. Precariedade do processo de cadastramento socioeconômico; \\
\hline & $\begin{array}{l}\text { 4. Falta de informação e esclarecimento à população afetada sobre } \\
\text { construção de barragens; }\end{array}$ \\
\hline & 5. Precariedade do processo de negociação atingidos/concessionárias; \\
\hline \multirow{4}{*}{$\begin{array}{l}\text { Dificuldades na } \\
\text { relação com os } \\
\text { organismos de } \\
\text { Estado }\end{array}$} & $\begin{array}{l}\text { 6. Ausência de fiscalização, pelo órgão regulador competente, de ações } \\
\text { sociais de responsabilidade das concessionárias; }\end{array}$ \\
\hline & $\begin{array}{l}\text { 7. Tratamento diferenciado das questões sociais no licenciamento } \\
\text { ambiental; }\end{array}$ \\
\hline & $\begin{array}{l}\text { 8. Participação insuficiente de Estados e Municípios no apoio aos } \\
\text { atingidos; }\end{array}$ \\
\hline & 9. Falta de condicionantes sociais em financiamentos a hidrelétricas; \\
\hline \multirow{5}{*}{$\begin{array}{l}\text { Ações do } \\
\text { empreendedor } \\
\text { que geram } \\
\text { problemas sociais } \\
\text { após concessão } \\
\text { da LP }\end{array}$} & $\begin{array}{l}\text { 10. Processo de licitação distorcido por desconsiderar os efetivos custos } \\
\text { sociais do empreendimento }\end{array}$ \\
\hline & $\begin{array}{l}\text { 11. Incompatibilidade entre cronogramas de construção de usinas e } \\
\text { barragens e programas sociais voltados à população afetada; }\end{array}$ \\
\hline & 12. Deficiências nos processos de reassentamento e indenização; \\
\hline & 13. Águas dos reservatórios "privatizadas" por concessionárias; \\
\hline & 14. Dívida social e questões emergenciais \\
\hline
\end{tabular}

Fonte: Relatório Final GTI Atingidos por Barragens

\subsection{VIABILIDADE AMBIENTAL É PARTE DA ESTRATÉGIA DE NEGÓCIO - A POSIÇÃO DA ASSOCIAÇÃO BRASILEIRA DA INFRAESTRUTURA E INDÚSTRIAS DE BASE - ABDIB}

AAssociação Brasileira da Infraestrutura e Indústrias de Base - ABDIB em maio de 2007, dedicou um número do seu boletim Análise Infra-estrutura, à discussão da qualidade ambiental dos empreendimentos de infra-estrutura. O texto intitulado "Inviabilidade ambiental: equívocos e riscos" manifesta a posição de que desenvolver a infra estrutura é política ambiental.

\footnotetext{
${ }^{51}$ Não acreditamos que os problemas e soluções relacionados ao licenciamento tenham uma única origem ou destino na complexa teia de relações do licenciamento ambiental. Ao contrário, temos convicção de que surgem em função de desacertos no sistema. Propomos a classificação problema dos atingidos por ator social com o qual vive a interface do problema, por acreditar que as soluções serão construídas na interação dos diversos atores, mas que ao identificar a interface por onde o problema se manifesta, automaticamente sugerimos aos atores que possam refletir como melhorar a qualidade desta interface.
} 
AABDIB defende a tese que a inexistência ou insuficiência de infra-estrutura é prejudicial à conservação dos biomas que ficam expostos a parcelas da população sem acesso a condições básicas.

Ainda que decidíssemos por uma política preservacionista e não construíssemos mais nada, qual o critério para decidir quem tem e quem não tem o direito de acesso a infra-estrutura mínima?

O texto diz que os empreendimentos de infra-estrutura são fiscalizados para evitar que erros cometidos contra o meio ambiente, no passado, voltem a se repetir. Nesse sentido, a moderna legislação ambiental do país "busca identificar os impactos reais e presumíveis, estabelecer as ações mitigadoras para reduzi-los e determinar quais as compensações financeiras referentes àqueles efeitos impossíveis de ser revertidos ou evitados" (ABDIB, 2007, p. 4).

O documento da ABDIB faz uma clara menção a qualidade da legislação ambiental brasileira, a qual considera uma das mais modernas do mundo, para depois cobrar que o Estado preveja mecanismos capazes de torná-la um instrumento eficaz da gestão ambiental e não um obstáculo à atividade econômica.

A entidade faz uma crítica explícita a duas situações tidas como críticas pelo relatório do Banco Mundial, a judicialização dos processos de licenciamento ambiental e os pedidos de complementações de informações. Diz o documento que "o risco dessa situação pode ser a desqualificação do sistema de licenciamento ambiental, o que seria um retrocesso institucional para o País. O licenciamento deve exatamente indicar de que forma minimizar e gerenciar os impactos no meio ambiente - e não somente impedi-los" (ABDIB, 2007, p. 6).

O boletim da ABDIB afirma que a eficiência é fundamental ao desenvolvimento futuro do país e chama atenção para dois fatos:

1. Os aproveitamentos hidrelétricos mais próximos aos centros de carga já foram utilizados, restam bons aproveitamentos na Amazônia legal. Que os atrasos na licitação e construção de hidrelétricas requer a compensação com outras fontes de energia;

2. Por fim, o texto comenta a respeito das condicionantes às vezes excessivas que são colocadas quando da emissão da licença prévia. 
Muitas das condições impostas aos investidores dizem respeito à ausência do Estado na prestação de serviços essenciais às populações locais - e não itens que dizem respeito restrito aos impactos ambientais e sociais da obra (ABDIB, 2007, p. 6).

Essa situação pode encarecer o projeto a ponto de torná-lo inviável economicamente.

A preocupação ambiental vai além do respeito à legislação e é um diferencial positivo para o projeto que passa a ter menores custos para obter financiamento, assim como, uma precaução à formação de passivos futuros.

Definitivamente, não há grande projeto de investimento que não seja destrinchado pelos agentes financeiros, preocupados com a saúde financeira dos clientes no longo prazo. A viabilidade ambiental não é mais uma exigência isolada de ambientalistas e de órgãos governamentais, mas passou a ser, sobretudo, uma prerrogativa de mercado (ABDIB, 2007, p.4.).

\subsection{SISTEMA FINANCEIRO E O DESENVOLVIMENTO DA INFRA-ESTRUTURA}

A afirmação contida no documento da ABDIB está referenciada em dois documentos produzidos no âmbito do sistema financeiro e que têm como premissa melhorar a qualidade dos empreendimentos de infra-estrutura financiados pelos bancos signatários.

\section{Princípios do Equador;}

II. Protocolo de Intenções pela Responsabilidade Socioambiental

O "Princípios do Equador" surgiu da iniciativa dos bancos ABN AMRO e do International Finance Corporation - IFC, braço financeiro do Banco Mundial. Em outubro de 2002 as duas instituições promoveram um primeiro encontro com executivos de mais três outras instituições: Barclays, Citigroup e WestLB, a fim de discutir experiências de investimentos em países emergentes.

Do primeiro encontro até o lançamento da primeira versão do documento em junho de 2003, houve duas outras reuniões do mesmo grupo, uma em Londres, onde se realizara a primeira e a outra em Dusseldorf, Alemanha, até que seis outras instituições - Crédit Lyonnais, Crédit Suisse, HypoVereinsbank (HVB), Rabobank, Royal Bank of Scotland e Westpac, juntaram-se ao grupo inicial e lançaram as regras através da quais as instituições signatárias pactuaram critérios para a concessão de financiamentos de grandes empreendimentos de infra-estrutura com valores igual ou superior a U\$ 50 milhões. 
Juntas, as 10 instituições privadas signatárias do documento são responsáveis por $70 \%$ do total de investimentos no mundo (DIAS \& MACHADO, 2007).

Os participantes dessa espécie de protocolo consideram que o financiamento ocupa papel central no desenvolvimento da infra-estrutura de países emergentes e que essa situação cria a oportunidade para que as instituições financeiras busquem interferir nos projetos estimulando práticas de "gestão ambiental e desenvolvimento com responsabilidade social" (OBSERVATÓRIO SOCIAL, 2004).

Os princípios acordados partem do pressuposto que ao se guiar pelos procedimentos estabelecidos, as instituições contribuem consigo, com seus clientes e com a sociedade, na medida que estimulará empreendimentos de melhor qualidade socioambiental. Na esteira das colocações feitas pela ABDIB, o texto afirma que

Esses princípios estimularão nossa habilidade de documentar e gerenciar os riscos relacionados a questões ambientais e sociais associados ao projeto que financiamos, permitindo-nos, assim, um engajamento pró-ativo com nossas partes envolvidas nas questões de política ambiental e social. O respeito a esses princípios nos permitirá trabalhar com nossos clientes no que diz respeito a suas questões de política social e ambiental relacionadas a seus investimentos nos mercados emergentes (OBSERVATÓRIO SOCIAL, 2004,pg.1)

Uma justificativa eminentemente econômica, uma vez que empreendimentos mais saudáveis socioambientalmente estão menos sujeitos a embargos judiciais.

Os projetos são classificados em três categorias (A, B ou C) "dependendo do tipo, localização, sensibilidade e escala do projeto e da natureza e magnitude de seus possíveis impactos ambientais e sociais" (OBSERVATÓRIO SOCIAL, 2004).

Os empreendimentos classificados nas categorias "A" e "B" são aqueles cuja legislação brasileira classificou como causadores de significativo impacto ambiental. Neste caso, sempre sem prejuízo da legislação local referente ao projeto, o proponente deverá proceder a avaliação ambiental do projeto, sem o qual, não será possível pleitear o financiamento.

O documento lista uma série de itens que deverão ser observados, além de apontar as diretrizes, indicadores e metas do IFC como referência na elaboração do projeto.

Três anos depois, em julho de 2006, foi aprovada uma segunda versão do documento. Mais rigorosa em relação a primeira, a atualização do "Princípios do Equador" aumentou o escopo dos projetos 
submetidos ao crivo do documento ao diminuir para U\$ 10 milhões o valor dos empreendimentos sob análise do protocolo que em abril de 2007 contava com mais de 50 grandes instituições como signatárias (MONTEIRO \& FERREIRA, 2007).

O "Protocolo de Intenções pela Responsabilidade Socioambiental” é uma iniciativa do governo brasileiro em relação ao papel que suas instituições financeiras podem desempenhar como indutoras do “desenvolvimento sustentável que pressuponha a preservação ambiental e uma contínua melhoria no bem estar da sociedade" (2008).

O documento é uma decorrência do "Protocolo Verde" de 1995, mas que não foi capaz de produzir resultados práticos, talvez em função de seu caráter genérico. A justificativa do termo celebrado em agosto de 2008 entre o Ministério do Meio Ambiente, BNDES, Banco do Brasil, Caixa Econômica Federal, Banco da Amazônia e Banco do Nordeste tem conteúdo mais político do que técnico e econômico.

Diferente do documento liderado pelo IFC (Princípios do Equador) que é explícito na conveniência econômica dos pontos acordados e indica critérios técnicos para elaboração das avaliações ambientais; o protocolo celebrado entre o governo brasileiro e os bancos estatais se faz justificar em função da urgência da gestão dos recursos hídricos, da preservação da biodiversidade, do manejo sustentável de florestas e do combate ao aquecimento global, por um lado. Por outro lado, pela convicção de que do ponto de vista social, o desenvolvimento sustentável envolve o respeito aos direitos humanos, ao trabalho, a valorização da diversidade e das culturas locais. (PROTOCOLO DE INTENÇÕES PELA RESPONSABILIDADE SOCIOAMBIENTAL, 2008).

O termo celebrado entre o MMA e os bancos chama atenção para o papel que as instituições financeiras têm em

empreender políticas e práticas bancárias que sejam precursoras, multiplicadoras, demonstrativas ou exemplares em termos de responsabilidade socioambiental e que estejam em harmonia com o objetivo de promover um desenvolvimento que não comprometa as necessidades das gerações futuras (PROTOCOLO DE INTENÇÕES PELARESPONSABILIDADE SOCIOAMBIENTAL, 2008, pg. 2).

O aspecto central do documento feito no âmbito do Estado brasileiro é o de que, a partir do proto- 
colo celebrado; as instituições bancárias estatais assumem a função de estimular práticas empresariais capazes de promover a harmonia entre a atividade econômica e a crescente demanda por práticas socioambientais nos negócios que tenham como resultado o desenvolvimento sustentável ou o não comprometimento dos serviços ambientais, por um lado; e o estímulo a diminuição da pobreza, por outro.

O "Protocolo de Intenções pela Responsabilidade Socioambiental" diferencia-se do "Princípios do Equador" na medida em que se propõe a ser referência propositiva da ação empresarial para além do financiamento de empreendimentos de infra-estrutura.

Além da indução de boas práticas em relação a essa atividade, o documento estimula que as próprias instituições assumam práticas socioambientais sustentáveis e que desenvolvam produtos que estimulem outras empresas a tomar o desenvolvimento sustentável como referência de sua atividade econômica.

\subsection{MAIS PARTICIPAÇÃO SOCIAL E TRANSPARÊNCIA AUMENTAM A LEGITIMIDADE DO PROCESSO DE LICENCIAMENTO: A PAUTA DO FBOMS}

O Fórum Brasileiro de ONGs e Movimentos Sociais e o Desenvolvimento - FBOMS produziu três documentos no ano de 2006 os quais analisamos dois que dizem respeito ao licenciamento ambiental. O terceiro documento "Comentários do GTEnergia sobre o plano decenal de expansão da energia elétrica 2006-2015” foi a posição do organismo sobre o plano decenal de expansão da energia elétrica que iremos tratar no capítulo final desta dissertação.

Os dois documentos divulgados pelo Fórum e que tratamos fizeram referência ao Acordo de Cooperação Técnica nº 003/2005, celebrado entre o Fórum, o MMA e o IBAMA.

O termo assinado pelas partes estabeleceu como objeto da iniciativa "o aperfeiçoamento das políticas públicas ambientais para o desenvolvimento sustentável” (Grifo meu). A agenda do Licenciamento Ambiental ocupou papel central nas atribuições da participação do FBOMS. De um 
total de cinco itens definidos como de responsabilidade do organismo da sociedade civil, quatro disseram respeito ao licenciamento ambiental:

a) propor medidas para aperfeiçoar e padronizar os procedimentos de licenciamento ambiental, em especial, de projetos de infra-estrutura;

b) propor medidas que possibilitem maior transparência e participação social nos procedimentos de licenciamento ambiental;

c) propor medidas objetivando a maior participação social na verificação do cumprimento das licenças ambientais expedidas pelo IBAMA;

d) colaborar com o MMA e o IBAMA na preparação de cursos, abertos ao público, sobre gestão ambiental, em especial, acerca do procedimento de licenciamento ambiental.

Os documentos publicados pelo FBOMS são críticos ao comportamento do governo em relação ao licenciamento ambiental e ao planejamento energético do país.

O documento intitulado "Perspectiva do FBOMS quanto ao Acordo de Cooperação com o MMA referente aos procedimentos do Licenciamento Ambiental" considera o planejamento energético brasileiro autoritário e critica o fato de o MMA estar a reboque do MME, sem fazer valer o princípio da transversalidade na elaboração de políticas públicas.

De acordo com o texto de 2 de agosto de 2006, os interesses econômicos do setor elétrico e de setores do governo têm prevalecido e há ausência do debate público e da transparência, sufocados em função das conveniências político-econômicas que não têm considerado questões técnicas e ambientais no processo de tomada de decisão do setor.

No mesmo dia, o Fórum da sociedade civil publicou outro texto com o título de "Sugestões do GTE/ FBOMS para o aprimoramento das regras de licenciamento ambiental". As contribuições divididas em três tópicos giram em torno das duas principais demandas anunciadas no documento citado anteriormente, em relação ao licenciamento ambiental: publicidade/informação e participação. 
1. Publicidade

- Melhorar a publicidade do início do processo de licenciamento utilizando outros meios de comunicação - rádio, TV e cartazes;

- Noticiar processo na imprensa regional e local;

- Informar às ONG’s ambientais e organizações locais do movimento social sobre a abertura do processo de licenciamento;

2. Melhorar informações sobre o andamento do processo. Fortalecer Sistema de Licenciamento Ambiental - SISLIC, ferramenta criada para permitir o acompanhamento dos processos de licenciamento via internet.

- Estabelecer quais documentos devem ser publicizados, e criar rotina de divulgação dos mesmos no SISLIC;

- Boletins digitais periódicos para informar público interessado sobre movimentação do processo;

- Toda documentação entregue teria correspondente em meio digital para que fosse disponibilizado para consulta no SISLIC.

3. Ampliar participação no processo de licenciamento - Participação da cidadania está restrita as audiências públicas na fase da Licença Prévia

• Criar momento de participação prévia à emissão do “Termo de Referência - TR” para que interessados possam apresentar pontos que consideram relevantes serem respondidos no EIA;

- Incorporar ao processo pareceres técnicos e políticos independentes;

- Incorporar a participação social no processo de emissão e revisão da licença de operação

Nas entrelinhas do documento de sugestões depreende-se que o FBOMS acredita que ao au- 
mentar o grau de publicidade e informação a respeito do processo de licenciamento, estimula-se ou permiti-se uma maior participação dos interesses da cidadania local. O resultado seria uma melhor qualidade do processo de discussão e mais legitimidade ao processo de licenciamento como um todo.

\subsection{FALTA DIÁLOGO PARA SE BUSCAR ALGUM CONSENSO}

Nas diversas falas dos atores envolvidos diretamente na discussão sobre os rumos do licenciamento ambiental no país ou da reflexão desse processo há ao menos um aspecto em comum sob os quais todos concordariam; a qualidade do diálogo não é suficiente aos desafios a serem enfrentados.

O referencial teórico da modernização ecológica identifica na falta de diálogo orientado para o consenso como uma das causas da falência das políticas ambientais da década de 70. A medida que mudou a qualidade do debate e o comportamento sistêmico de todos os atores envolvidos, as políticas passaram a ter maior conseqüência.

No próximo capítulo fazemos uma reflexão sobre o licenciamento ambiental no país à luz da modernização ecológica, a fim de perceber onde estão os gargalos e vicissitudes do instrumento tendo em vista de um lado, a necessidade do país de melhorar a qualidade e extensão de sua infra-estrutura, sobretudo a expansão da geração de energia hidrelétrica, e de outro, a garantia de que os empreendimentos tenham qualidade socioambiental que produzam desenvolvimento social ao invés de degradação e exclusão. 



\section{LICENCIAMENTO AMBIENTAL NO BRASIL SOB A PERSPECTIVA DA MODERNIZAÇÃO ECOLÓGICA - UMA ANÁLISE SOCIOLÓGICA

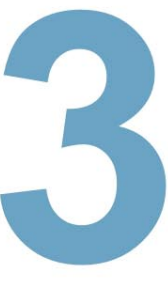

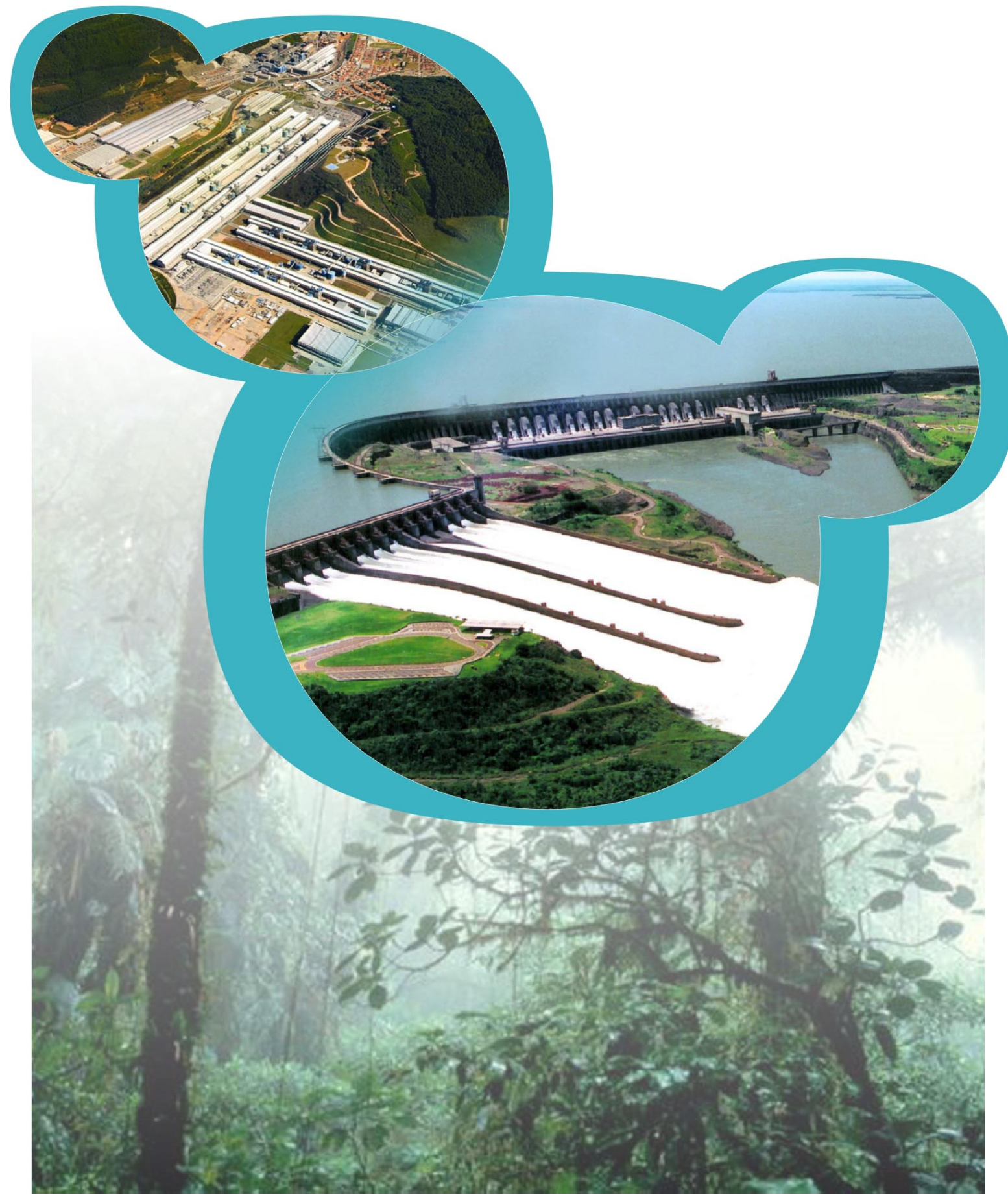




\section{Licenciamento Ambiental no Brasil sob a perspectiva da Modernização Ecológica}

\subsection{O CONTEXTO DA LEI 6938/81 - A POLÍTICA NACIONAL DE MEIO AMBIENTE}

A lei que instituiu a PNMA surge no contexto das discussões sobre desenvolvimento e meio ambiente, e não por outro motivo afirma duas vezes em seus quatro primeiros artigos (são 21), a necessidade de se promover o desenvolvimento.

E o licenciamento ambiental trata precisamente dessa possibilidade que a sociedade tem de produzir, sem, contudo, comprometer os serviços ambientais e as condições para o prosseguimento das diversas formas de vida. Pois, em sua gênese, as leis estaduais, especificamente as leis paulista e carioca, precursoras do licenciamento no país, refletiram o acúmulo da sociedade naquele momento, em relação ao conhecimento que se tinha das atividades comprometedoras do meio ambiente. No plano internacional, de maneira mais radical, também foram as atividades industriais as primeiras a serem questionadas pelo movimento ambientalista.

Neste sentido, a lei Nacional no 6.938 de 1981 reflete o posicionamento do Brasil no debate internacional sobre desenvolvimento e meio ambiente. Debate no qual o país teve participação controversa em 1972 quando, na Conferência Mundial do Meio Ambiente de Estocolmo, defendeu o direito de poluir se isso fosse necessário para o crescimento.

Em 1981 o país vivia o final da ditadura militar e uma lei modernizante das relações entre ambiente e sociedade, pode justificar-se mais pela tentativa de interação do país no debate internacional - já que sofrera pressão, desde quando se posicionara em 1972, pró-poluição do que refletir o debate interno.

Era o final do ciclo autoritário, é verdade, mas um fórum como o CONAMA não condiz com o ideário da transição lenta e gradual, muito menos com a criação de instrumentos que submeteria, inclusive o Estado, às discussões do impacto ambiental e da viabilidade ambiental de suas iniciativas. Sobretudo um governo com sabida vocação para a intervenção econômica, com ativa agenda industrial e executor de ambiciosos projetos de grandes obras de engenharia. 
No contexto de uma lei destinada muito mais a responder à pressão externa do que a refletir o acúmulo de discussões no país é que a PNMA é promulgada e o licenciamento ambiental passa a fazer parte do ordenamento jurídico nacional.

\title{
3.2 LICENCIAMENTO AMBIENTAL É MODERNIZAÇÃO ECOLÓGICA - ME
}

O autor holandês Arthur Mol (2001) reconhece os limites da modernização ecológica em países que não dispõem do que ele considera como algumas características mínimas necessárias à emergência da mesma.

Diz o sociólogo que:

\begin{abstract}
"A questão da adequação da ME para países em desenvolvimento levou a observações bastante críticas, vindas dos próprios estudiosos (Mol 1995; Frijins et al. 2000; Sonnenfeld 2000) e seus comentadores e críticos (Blowwers 1997; Blühdorn 2000; Buttel 2000b). Todos eles concordam que em alguns desses países em desenvolvimento as heurísticas da modernização ecológica são na melhor das hipóteses valores parciais em analisar as práticas e processos da reforma ambiental” (MOL, 2001, p.63).
\end{abstract}

Já dissemos no primeiro capítulo que não faz parte das ambições desse texto considerar o instrumental da modernização ecológica como algo pronto, acabado, e apto a uma aplicação universal sem adaptações ou mesmo sem uma gama de conceitos próprios.

O trecho citado acima é claro em apontar que existem limites a serem enfrentados do ponto de vista teórico e prático, uma vez que existe muito a ser construído nas sociedades em desenvolvimento.

Portanto, sabedores das limitações que o próprio instrumental teórico afirma ter em relação a países com nossas características, a intenção desse capítulo é propor um exercício em torno do licenciamento ambiental no Brasil sob a perspectiva da modernização ecológica.

Já contextualizamos acima o cenário no qual foi promulgada a PNMA que anima institucionalmente o licenciamento ambiental em todo o território nacional. Nesse contexto acreditamos que há possibilidade de diálogo entre a ME e o licenciamento ambiental propriamente dito.

Uma possibilidade desse diálogo é identificar aspectos a partir dos quais poderemos fortalecer o 
licenciamento por seus vínculos intrínsecos com processos políticos, econômicos e sócio-culturais que têm sido capazes de oferecer respostas eficientes à solução dos problemas socioambientais.

Dentre as características instituidoras da ME e a que Mol (2001) tem se referido como a heurística da modernização ecológica, a primeira anuncia uma mudança paradigmática do papel da ciência e tecnologia, que passam a ter importância pelo potencial que têm de curar e prevenir os problemas ambientais.

O uso mais estratégico de ambas teria o caráter de prevenção sociotecnológica, na medida em que estimulariam a incorporação da variável ambiental no planejamento de inovações organizacionais e tecnológicas.

O licenciamento pode ser considerado uma política de gestão preventiva, uma vez que busca se antecipar a problemas futuros e até mesmo estimá-los e quantificá-los, no sentido de minimizar situações não desejáveis, mas entendidas como inevitáveis frente a outras necessidades da sociedade a serem supridas.

Esse é um primeiro sentido, uma primeira convergência entre o licenciamento ambiental e o referencial teórico da modernização ecológica, que vê na prevenção uma ação legítima e capaz de garantir as condições para o desenvolvimento econômico sem o comprometimento do ambiente.

O princípio da "viabilidade socioambiental" aponta para a necessidade de se assegurar condições para que a tomada de decisões e a implementação de ações sejam, sobretudo, de natureza preventiva (Grifo meu) e ocorram em tempo hábil, de modo a evitar impasses decorrentes de conflitos de interesses mal equacionados e custos econômico-financeiros elevados para o setor elétrico" (BANCO MUNDIAL, 2008, p.16).

O próprio instrumental teórico, técnico e tecnológico mobilizado para a elaboração do EIA é outro ponto de convergência entre a modernização ecológica e o licenciamento ambiental, uma vez que, em tese, o EIA poderá concluir pela inadequação de determinado empreendimento em determinada localidade e então sugerir outro local ou outro arranjo técnico e tecnológico, como uma usina a fio d'água, ao invés de um projeto de UHE, que prescinda da formação de um lago ${ }^{52}$.

\footnotetext{
${ }^{52} \mathrm{O}$ projeto inicial das UHEs do Rio Madeira, que pressupunha o reservatório, era diferente do que foi licenciado. As UHEs são praticamente a fio d'água, com impactos socioambientais bem menores do que os relacionados no projeto anterior. A principal mudança que permitiu um projeto menos impactante foi o posicionamento das turbinas bulbo.
} 
O emprego do capital científico e tecnológico, a aplicação e o desenvolvimento do conhecimento a serviço da identificação, mensuração e análise dos custos socioambientais vão orientar a conveniência ou não do empreendimento, além de especificar o arranjo técnico e a localização mais apropriadas. Depois, esse mesmo instrumental será utilizado em métodos construtivos menos impactantes, na mitigação de ocorrências não desejadas e na compensação de eventuais resultados que sejam inevitáveis.

Empreendimentos destinados a prover a infra-estrutura do país, tais como grandes obras de engenharia civil - portos, aeroportos, hidrelétricas, estradas, prescindem de tecnologia e inovação em seus métodos construtivos, na concepção dos projetos, nos materiais utilizados e na utilização de maquinário cada vez mais orientado à precisão.

Empreendimentos industriais podem utilizar esta ou aquela matéria prima, ter este ou aquele método de rejeito do sistema produtivo, ter um ou outro tipo de emissão, assim como o próprio sistema de produção pode ser constituído de diferentes formas.

O licenciamento ambiental instrumentaliza a sociedade para que possa refletir e decidir sobre quais melhores projetos, arranjos produtivos, localização, matéria prima são mais adequados. Assim como, pode instruir sobre a disposição do rejeito de empreendimentos e ações produtivas que possam poluir ou degradar significativamente o ambiente.

O processo de tomada de decisão é, em tese, resultado de um balanço em que se busque um arranjo que favoreça a todos, sobretudo o corpo social como um todo, uma vez que terá o produto do qual necessita, mas produzido sob condições ambientalmente aceitáveis.

A modernização ecológica rompe com a oposição estruturante entre meio ambiente e sistema produtivo (MOL, 2001). E o que é licenciamento ambiental se não a instrumentalização da sociedade para que ela possa definir com a maior e melhor precisão possíveis quais limites está disposta a aceitar em nome do sistema produtivo, seja ele industrial, construtivo ou utilizador de recursos naturais?

O licenciamento ambiental é uma ferramenta, que bem ao gosto da ME, informa à sociedade os problema ambientais em potencial. Quantifica, qualifica e tipifica os prejuízos socioambientais que determinado processo produtivo impõe virtualmente à coletividade e propõe mecanismos de defesa, 
compensação, mitigação, sugere o limite do aceitável ou estabelece o ponto em que a relação custo benefício deixa de ser interessante ao coletivo.

Dito de uma maneira mais clara, o Licenciamento Ambiental é um instrumento técnico, que se utiliza de outros procedimentos técnicos e tecnológicos e auxilia no processo de tomada de decisão sobre a conveniência ambiental de determinados processos produtivos. Ao menos em tese.

Por fim, em que pesem todas as melhorias pelas quais clama o sistema de licenciamento ambiental no país, deve-se reconhecer os avanços que a aplicação do instrumento trouxe à sociedade brasileira, nos protegendo de desastres ambientais como a UHE Balbina, mas também sendo a referência a partir da qual, a UHE Barra Grande, no Rio Grande do $\mathrm{Sul}^{53}$ não pudesse entrar em funcionamento mesmo depois de erguida.

O estudo do Banco Mundial (2008) ao qual nos referimos várias vezes no capítulo anterior, mesmo que tenha partido do pressuposto que o licenciamento ambiental é um impeditivo ao desenvolvimento (p.28), reconhece que o licenciamento ajudou a melhorar a qualidade socioambiental dos empreendimentos $^{54}$ que compuseram o estudo de caso do trabalho.

Ao escolhermos a teoria da modernização ecológica como ferramenta teórica da reflexão sobre o licenciamento no Brasil, tínhamos em mente a existência de convergência entre as características do licenciamento ambiental enquanto um instrumento preventivo de gestão ambiental e a modernização ecológica enquanto um instrumental teórico que entende a ação preventiva como capaz de harmonizar as relações entre o sistema produtivo e o meio ambiente. Acreditamos que a relação entre uma e outra é forte o suficiente para garantir a legitimidade da reflexão.

A relação intrínseca entre o licenciamento e os arranjos técnicos e tecnológicos que conformarão os empreendimentos é a expressão política e econômica de uma opção da sociedade que reconhece a necessidade de empreendimentos potencialmente poluidores e degradantes ao meio ambiente, mas

\footnotetext{
${ }^{53}$ A UHE Barra Grande, depois de pronta não recebeu a licença de operação porque descobriu-se que o EIA, que havia subsidiado o processo de licenciamento, havia omitido 200ha de mata primária de Araucária. A situação foi solucionada através de um Termo de Ajuste de Conduta -TAC, celebrado entre empreendedor, governo e instituições locais.

${ }^{54} \mathrm{Um}$ bom exemplo de como o licenciamento ambiental tem influenciado positivamente e de forma concreta os empreendimentos hidrelétricos, são os já mencionados do complexo do Rio Madeira, que tiveram seus projetos alterados e impactos ambientais minimizados.
} 
entende que suprir as demandas sociais não está acima da responsabilidade que temos com o meio ambiente para nós e para as gerações futuras.

Há um diferencial crescente entre as condições ambientais das iniciativas empresariais. No caso dos empreendimentos industriais ou provedores de infra-estrutura, a viabilidade ambiental possui importância estratégica devido ao fato de ambos os setores (indústria e infra-estrutura) contarem com um expressivo passivo socioambiental.

Nesse contexto, o licenciamento ambiental funciona como uma espécie de carimbo que legitima a obra frente a financiadores, consumidores e (ao) Estado, a quem cabe licenciar os empreendimentos (que são licenciáveis).

Acreditamos que a ME é capaz de nos oferecer os elementos de que precisamos para refletir sobre o estágio atual do licenciamento ambiental como ele é, uma iniciativa do Estado preocupado em garantir as condições para o desenvolvimento dos processos produtivos dos quais carece a sociedade, sem que isso signifique danos que comprometam os serviços ambientais futuros. $\mathrm{O}$ instrumento confere legitimidade ao processo produtivo que oferece à sociedade o que ela precisa sem comprometer-lhe sua sobrevivência atual e futura.

O licenciamento é uma matéria de grande controvérsia no Brasil do início do século XXI, discutido publicamente pelos meios de comunicação no contexto de constante crise. O debate sobre licenciamento tem sido apresentado, sobretudo pela mídia, como o embate daqueles que querem o desenvolvimento contra aqueles que consideram desenvolvimento e respeito aos limites ambientais como elementos antagônicos.

Nesse contexto, é conveniente a utilização da modernização ecológica uma vez que seu instrumental se constituiu em cenário político semelhante, de forte embate entre o capital, de um lado, e o movimento ambientalista juntamente com a produção acadêmica científica sobre meio ambiente, do outro.

É verdade que a modernização ecológica tem se caracterizado até aqui mais adequada ao contexto dos países desenvolvidos; no entanto, como já dissemos, acreditamos que seu instrumental nos oferece saídas aos impasses vividos no sistema de licenciamento ambiental brasileiro, na medida em que 
sugere (outros) arranjos políticos, econômicos e sócio-culturais alternativos, eficazes na solução de problemas e conflitos ambientais.

Seja pelas convergências listadas acima, seja pelo estágio atual do licenciamento ambiental brasileiro onde co-existem elementos de modernização ecológica, mas ainda fortemente marcado pela oposição entre ambientalismo e desenvolvimentismo que marcou o início dos debates ambientais na contemporaneidade, entendemos que a ME oferece novas referências que podem reorientar o debate sobre licenciamento ambiental no país.

Além disso, o próprio licenciamento ambiental é um ato de modernização ecológica uma vez que, como dissemos, trata-se de uma iniciativa de cunho preventivo. Há no licenciamento uma série de interfaces modernizantes das relações entre meio ambiente e sociedade: recorrência à ciência e a tecnologia enquanto ferramentas de diagnóstico, análise e tomada de decisão.

O próprio sistema de concessão de licenças ambientais credita a ciência e a tecnologia como instrumentos capazes de fazer a mediação correta e necessária à instalação de unidades produtivas de menor impacto ambiental.

Não por outra razão, as informações que estruturam toda a análise do licenciamento são tipologia e localização do empreendimento, duas variáveis que podem ter valores múltiplos e que só podem combinar-se indistintamente com suporte técnico e tecnológico.

Por fim, o ideário da ME é uma referência válida para que se introduzam novos comportamentos no sistema de licenciamento ambiental do país. Não só pelas convergências que já apontamos, mas sobretudo porque na medida em que esse ideário foi capaz de contribuir para o estabelecimento do quadro de crise ambiental sistêmica, certamente poderá contribuir com o sistema de licenciamento brasileiro que tem baixíssima solidariedade entre seus atores e a lógica da disputa estabelecida.

De acordo com o conjunto de características principais da ME pensamos que o que acabamos de expor dialoga com ao menos três delas:

a) Mudança das funções da ciência e tecnologia na reforma e deterioração ambiental - Todo o processo de licenciamento ambiental está permeado pelo uso da 
técnica e da tecnologia, seja na produção dos estudos de impacto ambiental no qual utiliza instrumental técnico e tecnológico variado, seja na definição dos arranjos técnicos e tecnológicos que conformarão o projeto, seu sistema construtivo, produtivo ou de operação;

b) Aumento da importância das dinâmicas de mercado e agentes econômicos Apresentamos as iniciativas "Princípios do Equador" e o "Protocolo de Intenções pela Responsabilidade Socioambiental", que são iniciativas recentes que somam-se a outras como o ISE - Índice de Sustentabilidade Empresarial da Bovespa, do qual fazem parte algumas empresas participantes do setor elétrico, inclusive a própria Telebrás. No debate a respeito da mudança de localização da UHE Jirau ${ }^{55}$, os bancos procurados pelo consórcio Energia Sustentável do Brasil, liderado pelo grupo franco-belga Suez Energy não se comprometeram a financiar o empreendimento antes que uma consultoria independente avaliasse o projeto à luz do "Princípios do Equador" (WIZIACK \& BRITO, 2008).

c) Transformações nas funções do Estado-Nação - Ao pressupor a participação dos diversos interesses no processo de licenciamento ambiental - empreendedores e consultores, sociedade civil e órgãos públicos nos três níveis, o Estado abre mão de um processo de tomada de decisão orientado por suas convicções e traz outras racionalidades para compor seu entendimento sobre a interface dos interesses socioambientais frente às demandas econômicas por mais produção e crescimento econômico. As iniciativas do governo brasileiro, surgidas a partir de 2004, de abertura de canais de discussão com variados setores sociais em torno dos rumos do licenciamento, aprofundam o diálogo existente dentro do sistema e os fazem avançar para o campo do aperfeiçoamento das políticas públicas.

\footnotetext{
${ }^{55}$ A hidrelétrica Jirau foi leiloada pelo governo federal depois de obter a Licença Prévia, em processo liderado pela EPE, como estabelece a legislação. O grupo Suez ganhou o processo licitatório, mas sua proposta de exploração do potencial hidrelétrico mudou a localização do empreendimento prevista no edital de concessão. A mudança gerou críticas de grupos ambientalistas e também de outros concorrentes.
} 


\subsection{CONFLITOS AMBIENTAIS ENSEJAM DIÁLOGO - AS OPINIÕES SÃO MODOS PRÓPRIOS DE INTERPRETAR O MESMO PROBLEMA}

A nossa opção em dar voz no texto às reflexões que fazem os principais atores sobre o licenciamento ambiental foi por acreditar que os impasses vividos internamente, dentro do sistema de licenciamento e individualmente, na discussão dos empreendimentos isoladamente, dizem respeito a um tipo de cultura política que privilegia o confronto.

O Brasil é uma democracia que acaba de completar 20 anos - pela primeira vez vivemos tão longo período sem interrupções da normalidade democrática. As contradições sociais e econômicas vivenciadas no cotidiano têm reflexo na vida política do país.

Existem muitos graus de participação política e de mobilização social. Em que pese o aprendizado que a sociedade brasileira experimenta com a democracia continuada, parcelas significativas da sociedade são manipuladas politicamente (ainda existe voto de cabresto no país), e algumas experiências de democracia direta, como o orçamento participativo, põem em cheque o ideário da democracia representativa (AVRITZER, 2002).

Os conflitos relativos ao licenciamento ambiental no Brasil remontam a uma experiência do fazer político, no qual há pouco diálogo, assimetrias e muito enfrentamento, ainda que no discurso de atores como governo e setor empresarial, referendados pela legislação, apareça com certa frequência o caráter democrático do sistema de licenciamento.

No entanto, ao menos no que diz respeito ao licenciamento de hidrelétricas há um passivo histórico na relação entre empreendedores e sociedade civil que tem pairado como um fantasma sobre os processos de licenciamento.

A construção de hidrelétricas é conflituosa no mundo inteiro, o relatório da Comissão Mundial de Barragens (2000) reconhece:

(...) os últimos 50 anos também deixaram claro o desempenho e os impactos sociais e ambientais das grandes barragens. Essas fragmentaram e transformaram os rios do mundo, enquanto que estimativas globais sugerem que entre 40 e 80 milhões de pessoas foram deslocadas pelas barragens. À medida que as bases dos processos de tomada de decisão foram tornando-se mais abertas, participativas e transparentes em muitos países, 
a opção de construir grandes barragens foi sendo cada vez mais contestada, chegando ao ponto de colocar-se em questão a construção de novas grandes barragens em muitos países.

Os enormes investimentos envolvidos e os impactos gerados pelas grandes barragens provocaram conflitos acerca da localização e impactos dessas construções - tanto das já existentes como das que ainda estão em fase de projeto, tornando-se atualmente uma das questões mais controvertidas na área do desenvolvimento sustentável. Os partidários das barragens apontam para as necessidades de desenvolvimento social e econômico que as barragens visam satisfazer, como a irrigação, a geração de eletricidade, o controle de inundações e o fornecimento de água potável. Os oponentes ressaltam os impactos adversos das represas, como o aumento do endividamento, o estouro dos orçamentos, o deslocamento e o empobrecimento de populações, a destruição de ecossistemas e recursos pesqueiros importantes e a divisão desigual dos custos e dos benefícios" (CMD, 2000).

No Brasil, essa situação foi agravada pela postura do governo militar, que na base da força e sem diálogo construiu grandes hidrelétricas, algumas até sem nenhuma racionalidade econômico-ambiental e que desalojaram milhares de famílias.

$\mathrm{O} M A B$ surgiu no contexto do tratamento autoritário que a ditadura deu às famílias de agricultores no sul do país, a região com maior percentual do potencial hidrelétrico inventariado já construído, cerca de $50 \%$, contra $9 \%$ da região Norte.

No licenciamento ambiental ecoam vozes e sentimentos de embates próprios do licenciamento dos empreendimentos especificamente, mas também da disputa do projeto de sociedade e de país.

O licenciamento de grandes empreendimentos e de UHEs especificamente é discutido a partir da percepção que cada grupo social tem do projeto de país que espera construir em sua ação cotidiana. Ainda que haja concretude nos impactos socioeconômicos e ou socioambientais, a discussão que o licenciamento faz de fato, é a respeito dos custos que estamos dispostos a arcar ou não em virtude deste ou daquele modelo de desenvolvimento.

Os empreendimentos são discutidos sob a ótica do custo $\mathbf{X}$ benefício sem que ninguém explicite isso. O debate específico sobre determinado projeto é apenas mais um round de uma disputa entre duas concepções de sociedade: entre aqueles que consideram legítimo e útil à sociedade se apropriar dos recursos naturais, promover grandes transformações ambientais, sociais e econômicas para que a engrenagem continue funcionando e o conjunto da sociedade se beneficie pela produção contínua de riqueza, emprego, renda, bem-estar, desenvolvimento e progresso; e aqueles que não consideram 
legítimo que o conjunto da sociedade (pela perda de seus bens naturais) ou grupos sem poder econômico e político sejam sacrificados para satisfazer interesses particulares de perpetuação do poder econômico e político direcionado apenas aos interesses de uma minoria que já detém essa condição.

A análise conjunta dos documentos recolhidos na pesquisa e dos discursos produzidos por cada um deles corroboram com o relatório da Comissão Mundial de Barragens que identifica dois grupos em disputa, conforme transcrito anteriormente.

O paradoxo é que cada um dos grupos de fato parece acreditar que é o melhor orientado para o bem do interesse coletivo, ao contrário do grupo oposto.

A experiência da modernização ecológica aponta para mudanças de ordem cultural como elementos capazes de produzir melhora sistêmica. Diálogo e cooperação foram os elementos que permitiram uma guinada na política ambiental nos países onde a ME tem contribuído com a solução dos problemas ambientais.

\subsection{MAIS PARTICIPAÇÃO PARA EQUILIBRAR O JOGO - NAS AUDIÊNCIAS PÚBLICAS O PROJETO JÁ ESTÁ PRONTO}

Outro aspecto que tem contribuído para o ambiente de pouco diálogo sistêmico é o fato da legislação relativa à participação social ter pouco mudado nos últimos anos enquanto a sociedade tem experimentado inúmeras formas de participação e inclusão política. Os grupos organizados têm experiências na participação em fóruns deliberativos e formuladores de políticas públicas, e quando vão participar do licenciamento têm, via de regra, apenas a audiência pública para interagir com as instâncias decisórias.

Os atores sociais que emergiram nos anos 70 criaram novos espaços e formas de participação e relação com o poder público, à revelia do Estado. A densidade da movimentação, não só dos movimentos populares, mas também de instituições da sociedade civil articuladas com a resistência popular e desejosas de transformações e conquistas em relação à ampliação dos direitos civis e sociais, acabaram por influenciar a cultura política dos anos 80, e têm seu ponto alto na Constituição de 1988 (JACOBI, 2000). 
A década de 90 caracterizou-se por movimento capitaneado por forças e atores sociais na busca de novos formatos e desenhos de políticas públicas. O desejo de maior participação articulou por um lado a democratização do processo de construção e tomada de decisão das políticas públicas, e por outro, a melhor eficácia dos resultados. Esperava-se que, por meio da participação institucional dos cidadãos seria possível reverter o padrão de planejamento e execução das políticas públicas no Brasil (TATAGIBA, 2002).

A participação seria capaz de tencionar o aparato estatal, tornando todo o processo mais susceptível de controle por parte da sociedade. O Estado seria obrigado a estabelecer novos padrões de tomada de decisão que levassem em conta as demandas de grupos sociais historicamente distantes dos círculos decisórios.

O lugar da participação social nos processos de licenciamento está defasado em relação às outras experiências de interação institucional entre movimento social e Estado.

Tome-se como exemplo o MOAB. A tentativa frustrada ${ }^{56}$ do movimento em opinar na elaboração do Termo de Referência - TR, que orientou a elaboração do EIA da UHE Tijuco Alto, contrapõe-se totalmente com o conjunto das demais experiências que o movimento tem em diversos fóruns de participação social (SOUZA \& JACOBI, 2008).

O MOAB tem composição heterogênea, mas com predominância de integrantes das comunidades quilombolas do médio Vale do Ribeira. Tem acento no Comitê de Bacia Hidrográfica do Rio Ribeira do Iguape, faz parte do Conselho de Segurança Alimentar do Vale do Ribeira - Consad, e acaba de eleger o presidente do movimento, José Rodrigues da Silva, vereador do município de Eldorado; ou seja, enquanto o movimento luta há duas décadas contra a instalação da UHE Tijuco Alto, conquistou o direito de participar de outros fóruns de discussão e deliberação, mas no processo de licenciamento ambiental da hidrelétrica, restou-lhe fazer perguntas e ouvir as respostas dos empreendedores, quando na verdade, queriam poder ter discutido as bases do Estudo de Impacto Ambiental.

\footnotetext{
${ }^{56} \mathrm{O}$ movimento protocolou carta no IBAMA na qual afirmou o desejo de influenciar na definição do Termo de Referência, no entanto, foi privado da discussão, mesmo reiterando o desejo em mais de um comunicado. Esse fato foi apresentado e discutido em trabalho que apresentei em 2008, na IV ANPPAS, em Brasília, com o título "Licenciamento Ambiental e o Novo Ambiente Político e Cultural do Pós-Ditadura: o Caso da UHE Tijuco Alto".
} 
Jacobi (2000) identifica qualidades diferentes nas maneiras de participação citadina. No tipo de participação consultiva, o que é o caso do processo de licenciamento ambiental, mesmo que a posição do cidadão seja levada em conta, não interfere diretamente no processo decisório. Nos tipos de participação resolutiva e fiscalizadora há intervenção cidadã no resultado final da atividade pública, há o compartilhamento do poder decisório sobre o processo de gestão. Na modalidade fiscalizadora a participação permite maior controle e possibilita ações corretivas e reorientadoras da gestão pública.

O descompasso entre a experiência vivida pelos grupos sociais em outros fóruns e os limites que persistem nos licenciamentos cria tensão e dificulta a percepção do processo de licenciamento enquanto democrático, como reivindicou várias vezes o presidente das audiências públicas no ciclo de audiências do licenciamento da UHE Tijuco Alto. A análise do ciclo de audiências constatou que 43\% das falas dos dois servidores do IBAMA que presidiram as plenárias reivindicaram maior caráter democrático ao debate.

Tanto os espaços públicos como os conselhos gestores são verdadeiras escolas de democracia, e permitem que a partir do exercício prático que enseja acertos e erros, aprenda-se a participar e a negociar, sobretudo em relação à exigência dos direitos (FURRIELA, 2002).

A dificuldade dos grupos defensores dos interesses locais ${ }^{57}$ de participar do processo de licenciamento de maneira propositiva cria tensão e dificulta o acordo sobre o que será licenciado, uma vez que não há instância de onde possa surgir o acordo entre as partes interessadas.

Quando chega-se a audiência pública ${ }^{58}$, o projeto está quase todo definido, a probabilidade do empreendedor aceitar mudanças é mínima, seria equivalente a se desprezar os anos anteriores de trabalho que o levaram à audiência.

O estudo do Banco Mundial apresenta o dado de que até que se chegue à audiência pública, o

\footnotetext{
${ }^{57}$ Populações atingidas, movimento social local, ONGs e poder político local. Em algumas situações, instituições de fora, mas com atuação na região dos empreendimentos, compõem o grupo dos interesses locais.

${ }^{58}$ Nas próximas linhas faremos algumas observações a respeito da conveniência de o projeto só ser discutido com os atingidos, organizações sociais e poder político local, às vésperas da emissão da licença ou durante as audiências públicas. As eventuais críticas a essa opção não devem ser vistas como críticas ao instrumento da audiência pública e muito menos deve-se entender que consideramos estas plenárias despropositadas e inócuas. Ao contrário, reafirmamos sua importância mas as consideramos insuficientes para resolver todas as demandas de participação social no licenciamento ambiental.
} 
processo vive em torno de 876 dias, ou 2,4 anos. No licenciamento de Tijuco Alto, as audiências foram realizadas entre 6/07/07 a 10/07/07; três anos e seis meses depois de protocolado o início do processo em 27/01/2004.

Não é razoável supor que, depois de todo esse tempo com o projeto em análise, com inúmeras complementações dos estudos, tendo o processo corrido em inúmeras instâncias do governo, e às vezes de governos diferentes, o empreendedor vá se dispor a incorporar a opinião dos demais atores.

Há complicadores econômicos e até humanos que dificultam a incorporação das sugestões oriundas das AP's, uma vez que, depois de se debruçar mais de dois anos sobre uma proposta, é difícil que alguém produza mudanças que possam repercutir em todo o projeto, ou que impliquem retornar a fases já superadas. Demandaria no mínimo, mais tempo, uma espécie de inimigo daqueles que têm como função fazer o empreendimento entrar em operação.

É contra a racionalidade empresarial e também do Estado, promover modificações que possam fazer o projeto retornar a instâncias de análise já superadas, quando tudo está encaminhado para sua aprovação. Isso demandaria mais tempo e novos custos. Portanto é de se supor que as possibilidades de que uma Audiência Pública venha a contribuir com modificações na proposta do empreendimento são mínimas.

Se é mínima a probabilidade de que a AP produza modificações no projeto destinadas a contemplar os interesses locais, em que momento as posições dos interesses locais podem ser discutidas e incorporadas no âmbito da discussão dos empreendimentos se o momento de escuta dos interesses locais é justamente a audiência?

Como esperar que os interesses locais possam legitimar um empreendimento que produzirá tantos efeitos sobre suas vidas se não há oportunidade de discuti-lo efetivamente, enquanto em outras esferas políticas e sociais do debate público acumulam-se experiências de participação com interferência objetiva no curso da formulação e implementação de políticas públicas?

Não há racionalidade no fato do projeto só ser discutido publicamente depois de já ter tramitado por mais de dois anos, ou mesmo por um ano. Ninguém teria pré-disposição a dialogar com quem 
se apresenta com anos de atraso para opinar, questionar, e querer modificar arranjos que já estão amarrados. $^{59}$

Um importante aspecto do qual o estudo do Banco Mundial não tratou é o fato do desequilíbrio e desigualdade existentes entre os atores na tentativa de influenciar os rumos do processo de licenciamento. Porque a expectativa construída em relação à participação influencia a maneira como os atores legitimam o processo e se posicionam.

Durante o licenciamento de Tijuco Alto, a CBA/CNEC teve livre acesso a todas as instâncias de governo que lhe foram necessárias, reuniões com a equipe técnica do IBAMA (saudável e correto que tivessem), para que pudessem discutir critérios, pontos de vista, etc. Mas esse mesmo direito foi negado ao MOAB, um movimento reconhecido pela sua militância contrária ao projeto.

A equipe de técnicos analistas, de acordo com os autos do processo, fez duas idas a campo para vistoriar a região: a primeira visita ao Vale do Ribeira foi entre os dias 12/04/04 e 16/04/04 “visando obter subsídios para a elaboração do TR" (IBAMA, 2008, p.1); na segunda, entre os dias 10/04/ 06 a 13/04/06, “foi realizada vistoria na área de influência do empreendimento, com a participação de técnicos do IBAMA/SEDE, GEREX/SP e IAP”'(IBAMA, 2008, p.3).

Em ambas as situações, não ficaram mais do que dois dias no Vale do Ribeira, descontando-se o deslocamento de São Paulo para a região a ser vistoriada. Nas duas ocasiões, os analistas do IBAMA foram acompanhados pelos consultores da CNEC, o que em si não constitui nenhum problema.

É compreensível que quisessem mostrar a área, mas é claro, que devido ao pouco tempo hábil, foi feito um recorte do que deveria ser mostrado à equipe responsável pela análise do EIA, recorte esse feito sob o critério da CBA/CNEC. Será que não havia outras áreas que fossem do interesse dos pareceristas do IBAMA visitar?

Alguém pode responder que eles não conheciam a região e que a equipe de consultores é profissional,

\footnotetext{
${ }^{59} \mathrm{O}$ que aconteceu com a UHE Jirau, que depois da licença emitida o empreendedor solicitou mudança do local do empreendimento é raro. E note-se que não foi fruto de pressão externa, foram os estudos feitos pelo consórcio vencedor do leilão, que identificou outra localização mais adequada para o eixo da barragem. O que obviamente anima um longo debate que deveria redundar em outro processo de licenciamento, uma vez que a licença concedida foi para uma localização e não para a que se propõe agora.
} 
e certamente montaram uma agenda a partir de critérios estritamente técnicos, o que provavelmente é verdade. No entanto, o "parecer técnico dos consultores" constitui-se especificamente por um único objetivo, qual seja, o de fazer aprovar a licença.

Não se pode esperar que os técnicos do IBAMA sejam levados pelos consultores a um local onde o estudo de impacto ambiental é falho, omisso, pouco descritivo, e certamente esses lugares existem, pois se não existissem, a equipe do órgão licenciador não teria solicitado tantos pedidos de complementação ao EIA ${ }^{60}$.

A falta de diálogo da equipe com os interesses locais pode tê-los privado de conhecer realidades que pudessem ser relevantes ao processo de concessão da licença, ao menos para as pessoas que estão ali cotidianamente, e que, diga-se de passagem, devem conhecer a região melhor do que qualquer pessoa de fora, ainda que exista toda legitimidade para que o EIA seja feito e analisado por pessoas de fora da região.

Não se trata de negar legitimidade aos consultores da CNEC e muito menos aos técnicos do IBAMA (de fazerem seu trabalho). Trata-se de reconhecer que os interesses locais precisam ter junto ao IBAMA a mesma correspondência que os interesses do empreendedor têm. A percepção desse desequilíbrio por si só já contamina o processo e politicamente desmoraliza o potencial do licenciamento enquanto instrumento de formação de consenso a respeito do empreendimento.

Do ponto de vista técnico, também é um erro que o conhecimento que a população local tem do lugar não seja aproveitado. Deveria se tratar de condição metodológica à elaboração do EIA aproveitar o conhecimento que os moradores locais têm da região.

A antropóloga Edna de Castro (2000) aponta a conveniência de se incorporar o conhecimento das populações tradicionais como instrumento de busca de soluções adequadas aos ambientes nos quais essas populações convivem e, portanto, têm percepção e mais precisa dos mecanismos a partir dos quais são regidos.

“O sistema de licenciamento precisa ser pensado, regulado e reorientado para ser um processo capaz

${ }^{60}$ Tanto o estudo do Ministério Público, quanto do Banco Mundial, identificaram problemas em Estudos de Impacto Ambiental em relação ao solicitado nos TRs. 
de criar sinergia entre os atores, valorizar a cooperação entre eles e, não a disputa e a falta de cooperação" (BANCO MUNDIAL, 2008, p. 11).

\begin{abstract}
a dimensão do conflito é inerente a esse processo (participação pública), como o é a própria democracia, e que os espaços de formulação de políticas que contam com a participação da sociedade civil não apenas são inerentemente marcados pelo conflito como representam um avanço democrático precisamente na medida em que publicizam o conflito e oferecem procedimentos e espaço para que ele seja tratado legitimamente. A ausência de espaços desse tipo facilita a tomada de decisões e a formulação de políticas através de um exercício autoritário do poder, onde o Estado ignora e deslegitima o conflito ou o trata nos espaços privados dos gabinetes, com os que a eles têm acesso (DAGNINO, 2000, pg. 300).
\end{abstract}

O envolvimento de grupos sociais diversos em um mesmo âmbito de discussão, com interesses diferentes e às vezes antagônicos, é um exercício de difícil execução; no entanto, expostas as divergências, debate feito e formulado o acordo, a sociedade ganha ao não ter mais que perder tempo com a discussão da discussão que deveria ter ocorrido e não ocorreu, como atualmente se discute em torno do processo de licenciamento de Tijuco Alto e da realização ou não das audiências públicas em Cananéia e Iguape.

A cultura político-social resultante destes espaços é que pode se tornar o grande diferencial capaz de melhorar a qualidade do processo decisório e, portanto, do conteúdo do mesmo, uma vez que o estímulo ao debate, negociação e deliberação ajuda a fomentar um ambiente de pactos e mútua legitimação do processo deliberado.

As audiências públicas deveriam servir muito mais para coroar todo o processo de discussão do que simular uma participação que racionalmente tem pouco potencial de produzir resultados concretos. Como já chamamos atenção, não há a mínima lógica em se modificar um projeto após transcorridos dois anos de tramitação.

Do nosso ponto de vista, o processo de licenciamento deve ser coordenado pelo IBAMA e feito pelo grupo de consultores contratados ${ }^{61}$, mas com uma agenda de encontros entre IBAMA, consultores, empreendedores e os interesses locais, para que os estudos possam ser discutidos e os resultados de progresso submetidos ao conhecimento dos interesses locais, que ganham assim a possibilidade de sugerir correções pontuais.

\footnotetext{
${ }^{61}$ Durante o ciclo de audiências referente a Tijuco Alto, o movimento social chamou atenção para o fato de que havia uma contradição entre o fato de o empreendedor contratar o EIA. De acordo com o novo modelo do setor elétrico cabe a EPE a contratação dos estudos que orientarão a análise para a emissão ou não da Licença Prévia. Entendemos que a contratação dos estudos por um órgão do Estado ajuda a reduzir a tensão do debate.
} 
O modelo atual favorece que o processo se arraste por anos, mas que uma hora enfim saia. Pois tratase menos de conformar as condições ideais para obtenção da licença e mais de superar os obstáculos até que zerados, o IBAMA conceda a licença.

\subsection{O QUE “LICENCIAR” - UM ACORDO A CONSTRUIR}

Os conflitos internos ao licenciamento têm uma chance se a sociedade conseguir identificar onde estão de fato os dissensos e os consensos; aliás, do ponto de vista do discurso, há uma enorme possibilidade de acordo, uma vez que todos os atores são unânimes em afirmar a validade do instrumento.

O licenciamento ambiental é legitimado socialmente, o que lhe confere força (o) suficiente para ser discutido não mais a partir do que ele deveria ser, mas sim do que ele é, e de quais esforços são necessários para a sociedade fazê-lo avançar em direção das novas necessidades que o desenvolvimento econômico, político e social impõem.

\section{É importante ficar claro: o que é "licenciável”, como e em quais condições ou com quais contrapartidas, é um objeto de disputa, de construção, de acordo. A palavra conceito, em torno} do licenciamento é "acordo".

Os atores envolvidos com a discussão do sistema de licenciamento precisam assumir a inexistência do licenciável e a necessidade de um acordo para cada empreendimento.

Não existe a priori projeto que seja licenciável ou que não o seja. O licenciador é uma espécie de termômetro social que toma a decisão depois de organizar as informações técnicas, econômicas e políticas disponíveis e acessadas durante o licenciamento.

Um empreendimento que hoje é licenciável poderá não sê-lo um ano depois, assim como um projeto que não obtém licença, poderá obtê-la dali a um tempo.

O ato de licenciar é um ato administrativo mediado pela expertise técnica, mas de alto conteúdo político, e não a toa autoridades públicas importantes, são às vezes levadas a se posicionar. 
O sistema de licenciamento está caracterizado por uma lógica de disputa, na qual, embora prescinda de acordos para que cumpra seu papel, o único acordo existente é que não há acordo.

Oque pode se esperar do licenciamento ambiental é que, enquanto instrumento, possa criar sinergia suficiente entre seus atores a fim de que sejam capazes de racionalmente decidir a respeito da viabilidade ambiental de um empreendimento ou atividade a partir de um balanço positivo do mesmo, no qual todas as suas variáveis são levadas em conta, inclusive a (variável) do resultado ambiental da concessão da licença, e no caso de negada, qual o custo ambiental da alternativa ao empreendimento ou atividade e qual o custo socioambiental de não licenciar e não se aprovar alternativa, ou seja: quanto custa não fazer nada?

Empreendimentos e atividades licenciáveis, o são por conta de sua complexidade na interface ambiental, mas muitas vezes tratam-se de atividades, produtos, e serviços, dos quais a sociedade não pode prescindir, e o sistema de licenciamento não pode ignorar essa realidade.

O sistema de licenciamento não pode ignorar os problemas acarretados pelo não-licenciamento de uma UHE e, por isso, é importante que enquanto sistema esteja pronto também para não aprová-la se for o caso. A sociedade não pode ficar refém de maus projetos só porque precisamos de energia. A sociedade já tomou essa decisão, e caso quiséssemos energia e estradas a qualquer custo, não precisaríamos recorrer ao licenciamento.

O sistema tem que ter sinergia o suficiente para que procedimentos cooperativos orientados para o bem comum protejam a sociedade dos maus projetos, sejam eles quais forem.

A sinergia à qual me refiro é a orientação para o acordo. De maneira alguma se pretende que os atores abandonem suas perspectivas e suas individualidades políticas e discursivas, mas que sejam capazes de superar o ambiente de não cooperação, de disputa, no sentido de se encontrar uma atitude racional que entenda o licenciamento de cada empreendimento dentro da complexidade na qual ele se insere.

A maneira como o sistema funciona hoje está vulnerável aos maus projetos. Os empreendimentos são licenciados não por seus méritos socioambientais e sim porque são capazes de enfrentar todas as adversidades de um processo. Até que superado o último obstáculo, não resta outra coisa ao IBAMA que não licenciá-lo. 
Como a lógica sistêmica é do confronto, aqueles que resistem ao tiroteio têm sua licença aprovada. Como o cenário é de escassez, sobretudo de energia, o governo também está pressionado para aprovar novos projetos, mesmo que não sejam os mais adequados ${ }^{62}$.

O interesse ambiental requer outra lógica do sistema de licenciamento, afinal, diferente da gestão dos recursos hídricos, que tem indicadores claros e objetivos a perseguir, tais como quantidade e qualidade da água - odor, cheiro, aspecto. Não há definição positiva do que seja um empreendimento licenciável se o pressuposto é que todos necessariamente causam impactos.

A orientação para o acordo é uma tentativa concreta de definição positiva de projetos licenciáveis. Ou seja, o sistema assume postura propositiva.

A avaliação ambiental integrada que a EPE está encarregada de fazer é um passo importante na medida em que deixará estabelecido para o empreendedor qual a qualidade mínima que se espera dos empreendimentos.

\subsection{COOPERAÇÃO - MAIS MODERNIZAÇÃO ECOLÓGICA PARA FORTALECER O LICENCIAMENTO AMBIENTAL}

Há uma questão concreta em torno dos empreendimentos hidrelétricos que não é mais passível de disputa. Os trabalhos da Comissão Mundial de Barragens ${ }^{63}$ e a Política Operacional 4.12 Reassentamento Involuntário do Banco Mundial, são claros em apontar que esses empreendimentos podem causar sérios problemas às sociedades e em especial aos grupos sociais diretamente atingidos pelos empreendimentos, caso não haja políticas específicas e realmente comprometidas com a supera-

\footnotetext{
${ }^{62}$ Não por outro motivo, a UHE Barra Grande entrou em operação depois que o MME coordenou a elaboração e assinatura de um TAC. O empreendimento que foi licitado e recebeu licença de instalação no governo do Presidente FHC omitiu em seu EIA a existência de 200ha de mata primária de Araucária.

${ }^{63}$ Em abril de 1997, com apoio do Banco Mundial e da IUCN - União Para Conservação Mundial - grupos representando diversos interesses reuniram-se em Gland, Suíça, por ocasião da publicação de um relatório do Banco Mundial, para discutirem questões envolvendo as grandes barragens. O workshop reuniu 39 participantes de governos, do setor privado, de instituições financeiras internacionais, de organizações da sociedade civil e de populações afetadas. Uma das propostas resultantes do encontro foi que todas as partes trabalhassem juntas para estabelecer a Comissão Mundial de Barragens que iniciou seus trabalhos em maio de 1998 e entregou o relatório dois anos depois em 2000. O relatório é um marco na discussão sobre barragens no mundo. A comissão contou com a participação de brasileiros, o Prof. José Goldemberg do Instituto de Energia e Eletrotécnica da USP e o MAB - Movimento dos Atingidos por Barragem.
} 
ção dos problemas causados pelos empreendimentos. Inclusive com o cumprimento dos acordos, algo problemático nesse segmento:

(...) o reassentamento involuntário em projetos de desenvolvimento se não for complementado com medidas atenuantes, causa, muitas vezes, graves riscos econômicos, sociais e ambientais: os sistemas de produção são desagregados; pessoas deparam-se com um empobrecimento quando perdem o seu patrimônio ou fontes de renda; populações são realocadas para locais onde a respectiva capacidade de produção pode ser menos utilizada e a competição pelos recursos maior; instituições comunitárias e as redes sociais são enfraquecidas; grupos de familiares são dispersados; e a identidade cultural, autoridade tradicional e o potencial para ajuda mútua se perdem ou diminuem (BANCO MUNDIAL Vol III - Anexos técnicos, 2008, p.134).

Seja como for, a verdadeira lucratividade econômica dos projetos de grandes barragens permanece imponderável, pois os custos ambientais e sociais foram mal contabilizados em termos econômicos. Em particular, a não contabilização desses impactos e o não cumprimento dos compromissos assumidos levaram ao empobrecimento e sofrimento de milhões de pessoas (WCD, 2000).

A atividade econômica nas sociedades do século XXI exige uma atitude de maior e mais cooperação com o ambiente societário, o que não significa que esta (cooperação) exista no grau e quantidade que a sociedade espera. Esse novo contexto político e social tem impacto econômico que molda novas formas de produção e de posicionamento no mercado, e principalmente, de respeito aos pactos constituídos coletivamente.

A crise econômica desencadeada pelo sistema financeiro dos Estados Unidos no final de 2008 foi o sinal que faltava à humanidade de que estamos todos ligados. Decisões econômicas têm impacto sobre a vida das coletividades, o que confere caráter público às decisões de boa parte das corporações (BOBBIO, 1987), daí a importância de mecanismos de governança coorporativa, tais como transparência, responsabilidade social, boa gestão financeira, ética nos negócios etc.

Habermas $^{64}$ apontou a inapetência do mercado para com os interesses do coletivo, o que levou ao surgimento do Estado de Bem Estar Social.

O primeiro consenso após a tomada de consciência da crise econômica, que se espalhou pelo mundo, no final da primeira década do século XXI, foi de que só com a intervenção do Estado seria possível enfrentá-la em condições não de vencê-la, mas de proteger a sociedade de resultados catastróficos.

\footnotetext{
${ }^{64}$ Mudança Estrutural da Esfera Pública. Rio de Janeiro: Tempo Brasileiro, 1984.
} 
Ao refletir sobre a emergência da sociedade moderna, Habermas (1934) diz que o "Estado do bem estar social" surge diante da constatação de que a regulação da vida social a partir do mercado criou as condições para o desenvolvimento econômico e garantiu o processo de integração política da burguesia, que assim aumentou sua riqueza e passou a participar direta e ativamente do processo de tomada de decisão das grandes questões sociais, sem, contudo, oferecer aos não burgueses as mesmas condições.

Na teoria e na práxis do Estado Liberal de direito, direitos liberais do homem e direitos democráticos do cidadão só se separam, assim como o ordenamento jurídico privado e a ordem pública em geral fixada constitucionalmente, quando o caráter fictício da ordem social hipoteticamente subjacente se torna consciente e a dominação da burguesia, paulatinamente concretizada em prol da própria burguesia, desvela a sua ambivalência (HABERMAS, 1984, p.261).

A discussão desloca-se do campo eminentemente econômico e passa a ser uma questão política na medida em que é no campo de interação entre associações públicas (movimento social), legislativo e executivo que vão se formar novos consensos em torno das funções do Estado em suas relações com os cidadãos.

A percepção generalizada de que a prometida igualdade não tinha efetividade no campo material e político fez deslocar o lugar social do Estado. Essa transformação ajudará a estabelecer novos parâmetros materiais e de participação política do cidadão.

Surge uma multiplicidade de interesses privados corporativos que se entrecruzam e se fortalecem na mesma medida em que o sistema econômico se expande e se complexifica. Caberá ao Estado cuidar pelo equilíbrio das relações sociais, conformando-o no que no século XX conheceremos como Estado-Social: (...) “já aventamos a tarefa de proteger, indenizar e compensar os grupos sociais mais fracos: trabalhadores e funcionários, inquilinos, usuários, etc. (neste âmbito recaem, por exemplo, as medidas com o objetivo de redistribuir a renda)" (HABERMAS, 1984, pg. 175).

A emergência do Estado social faz alterar a estrutura da esfera pública do Estado liberal. Neste, a esfera pública era formada pela participação privada dos indivíduos, naquele o processo de interação pública se dá a partir da organização dos interesses privados. A esfera pública que no Estado Liberal tinha a economia como seu motor, no Estado social tem a política como elemento dinamizador.

Pois não se trata mais de indivíduos privados atuando em prol de seus interesses comerciais, mas sim de cidadãos organizados coletivamente em associações (movidas pela defesa de interesses privados e em parte econômicos, mas não só) que publicamente, seja com o Estado ou mesmo 
entre si (por meio de associações) vão procurar construir os compromissos políticos que irão acomodar os interesses em disputa.

Nos últimos anos, o governo federal tem tido uma série de iniciativas voltadas para o sistema de licenciamento ambiental, mais especificamente de hidrelétricas. O ponto de partida desse processo é o novo marco regulatório do sistema elétrico nacional de 2004, que inovou ao estabelecer a necessidade da emissão da LP para a licitação dos empreendimentos hidrelétricos.

Essa exigência do setor elétrico tende a oxigenar o setor de licenciamento do país, pois, de certa forma, atrela a expansão do sistema elétrico à resolução dos problemas da agenda de licenciamento ambiental.

A criação da EPE e a designação que a empresa faça as avaliações ambientais integradas mudam o paradigma nacional em relação ao barramento de rios. O setor passa a incorporar a seu planejamento estudos que apresentem a relação sinérgica dos empreendimentos em uma mesma bacia; procedimento, que por inexistente, se constituía como uma das principais fragilidades do sistema de licenciamento de UHEs.

Em 2004, o Ministério do Meio Ambiente montou uma agenda de discussão com a ABDIB em torno do licenciamento que resultou em um acordo de cooperação técnica.

A criação do "GTIAtingidos por Barragem”, a contratação no âmbito de dois ministérios conflitantes sobre a matéria do licenciamento ambiental de hidrelétricas, a saber MME e MMA, do estudo do Banco Mundial, e as inúmeras ações legislativas que o governo federal tem tido marcam uma proatividade que privilegia como resultado a cidadania.

Estas iniciativas tendem a procurar os caminhos para fortalecer o sistema de licenciamento do país e provocar outro agir sistêmico dos principais envolvidos sobre este importante instrumento da gestão ambiental.

O licenciamento ambiental enquanto ferramenta de planejamento utiliza a ciência e a tecnologia a serviço dos interesses ambientais. E as recentes iniciativas do Estado brasileiro em relação à refle- 
xão dos problemas e caminhos a solucionar são modernizadoras das relações entre ambiente e sociedade na medida em que buscam fortalecer o instrumento pela via do diálogo com todos os atores envolvidos.

Ao incentivar o diálogo dentro do sistema, o governo busca imprimir qualidade no debate, uma vez que o mesmo passa a ser feito sob a expectativa de que haja acordo, e não de confronto e uso da força enquanto recursos ao cumprimento da lei.

Ao instituir a legislação que criou o licenciamento ambiental e ao dar continuidade à publicação de todo o ordenamento jurídico que o anima, o Estado buscou proteger o cidadão de práticas particularistas, que em oposição ao próprio discurso de desenvolvimento, produziam poluição e ou degradação ambiental, prejudicando toda a coletividade.

O caráter preventivo do instrumento é uma tentativa estatal comprometida com toda a coletividade. Neste sentido, as recentes iniciativas em torno do licenciamento reforçam mais ainda sua gênese preventiva, uma vez que surgem também referendadas pela percepção de que os problemas que descaracterizam a iniciativa da PNMA, se não resolvidos, podem retirar a legitimidade e a força de sua existência e aplicação.

De acordo com Mol (2001) deve haver condições sociais e políticas mínimas para a emergência da modernização:

\begin{abstract}
Por exemplo, a existência de um welfare state com responsabilidades ambientais institucionalizadas e articuladas, desenvolvimento tecnológico avançado dentro de uma sociedade altamente industrializada, uma economia de mercado regulamentada pelo Estado cobrindo todas as partes da sociedade e estritamente conectada ao mercado mundial globalizado, e consciência ambiental institucionalizada, generalizada, relativamente profunda. Nos primeiros escritos (Mol 1995; Frijns et al. 2000), eu e meus colegas argumentamos que estas características institucionais são pré-condições para uma aplicação bem sucedida dos modelos de reforma ambiental baseados na Teoria da Modernização Ecológica (MOL, 2001, 64).
\end{abstract}

As características às quais reivindica o autor pressupõem Estado forte, não a figura paquidérmica e autoritária normalmente associada à presença de um poder público atuante e defensor dos interesses da coletividade. 
Falamos da intervenção mediadora sugerida por Habermas, e apresentada como condição por Mol. Ambos reivindicam o welfare state como ponto de partida e não por acaso. Pois tanto um como outro, estão preocupados em como resolver questões relacionadas ao desequilíbrio provocado pela emergência de grupos que se fortalecem em demasia, a ponto de tornar vulneráveis aqueles que estão a sua margem.

Habermas falava do desequilíbrio econômico; a modernização ecológica por sua vez preocupa-se com desequilíbrios socioambientais, mas entendendo-o de forma radicalmente contrária.

Se para Habermas, o desequilíbrio econômico provoca uma contradição estruturante entre a burguesia e os não burgueses, a ponto de provocar novos formatos de sociabilidade com impactos na política; para a modernização ecológica, os desequilíbrios socioambientais ganham uma chance de solução, caso surja o diálogo a partir do conflito. Aqui não há uma condição que deva opor-se estruturalmente uns aos outros, porque a solução interessa a todos.

Nesse sentido, para Habermas, o Estado toma partido para proteger os que estão em desvantagem econômica e social. Para os teóricos da ME, o Estado toma partido para organizar um sistema que tenda sempre ao equilíbrio, ao invés de ditar, faz mediação ao provocar o posicionamento dos diversos atores envolvidos e organizar um sistema de ações no qual cada um tem um papel a cumprir.

Do ponto de vista desta pesquisa, acreditamos que o licenciamento ambiental tem características de uma política ambiental modernizante e que os avanços necessários ao fortalecimento desse instrumento passam por mais modernização ecológica - mais diálogo sistêmico, maior participação social, mais ciência e tecnologia nos arranjos técnicos e produtivos.

A agenda da autoridade governamental com os diversos atores do sistema de licenciamento está em curso, a novidade desse diálogo e o pouco tempo que nos separa do início da iniciativa não nos fornecem ainda elementos que possam respaldar uma reflexão de resultados. 


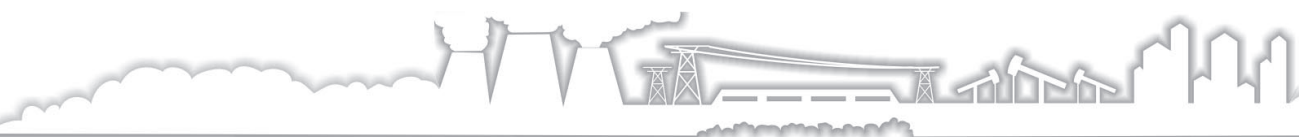

No entanto, entendemos que se a agenda evoluir para rodadas presenciais de diálogos coletivos e multi-atores, como o apresentado na contribuição do Banco Mundial ao debate, o Brasil ganha a oportunidade concreta de fazer avançar sua agenda ambiental.

Como já dito, um aspecto importante da modernização ecológica (HAJER, 1996) é a aprendizagem institucional que ocorre com os atores no processo de interação e que isso pode produzir mudanças significativas nos processos. 



\section{A UHE TIJUCO ALTO: ESTUDO DE CASO E REALIDADE SOCIOECONÔMICA DO VALE DO RIBEIRA

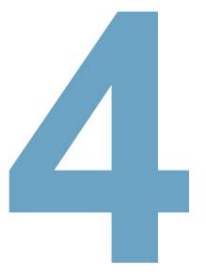

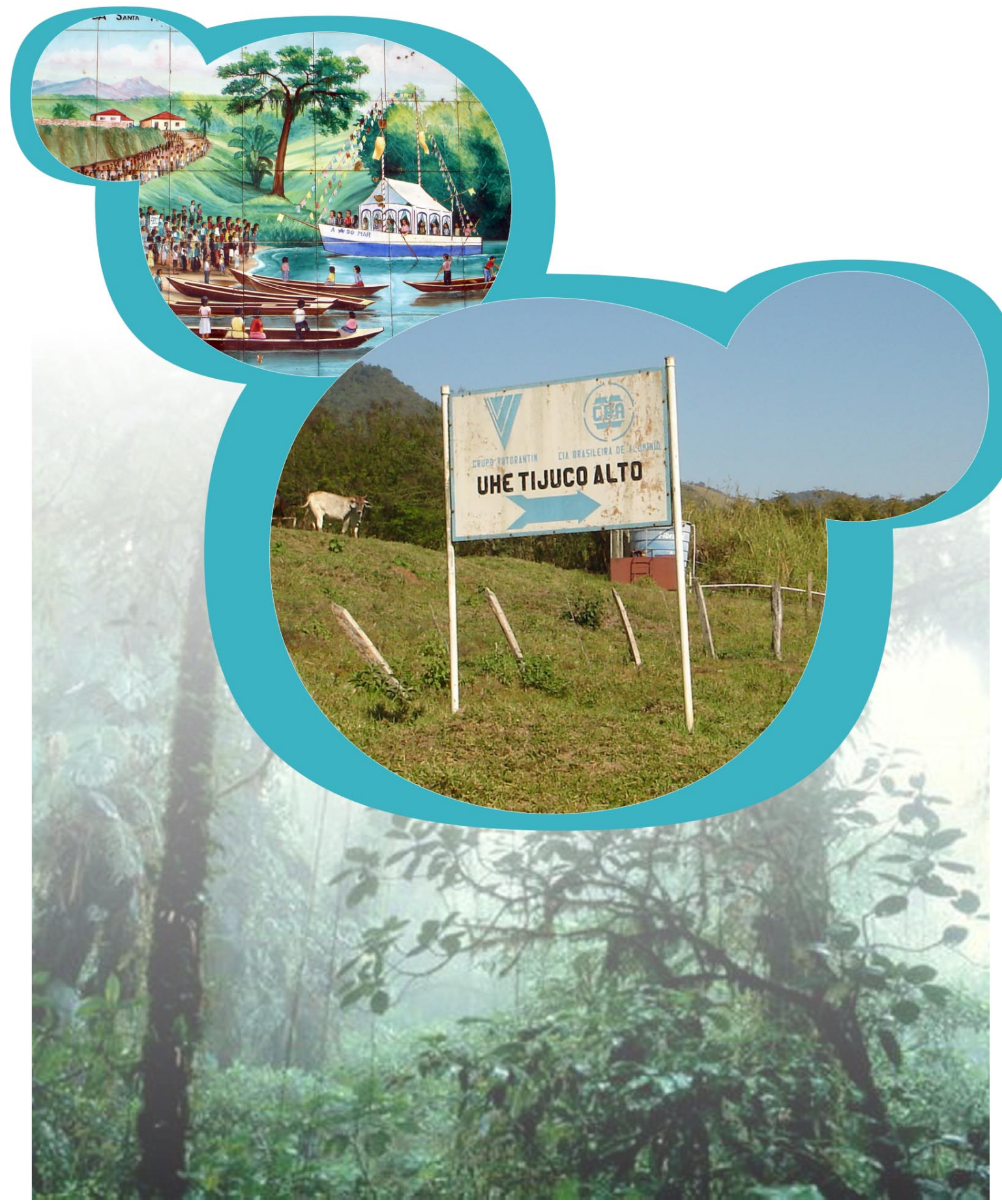




\section{UHE Tijuco Alto: Estudo de Caso}

\subsection{O VALE É UMA RESERVA ECOLÓGICA}

O Vale do Ribeira fica no sudeste do Estado de São Paulo e tem $68 \%$ do território coberto por Mata Atlântica (COELHO \& FAVARETO ETC E TAL, 2006), a maior faixa contínua deste bioma no país. Na região está localizado o Complexo Estuarino-Lagunar de Iguape - Cananéia - Paranaguá.

A região tem flora e fauna diversificadas mantidas em Unidades de Conservação - UCs de várias categorias que contemplam diversos usos, desde o lazer para a população em geral, até o uso restrito para a pesquisa científica. As UCs, englobam cerca de 60\% do território regional (ROMÃO, 2004).

Figura 1 - Rio Ribeira é cercado por densa vegetação. $68 \%$ do território é faixa contínua de Mata Atlântica

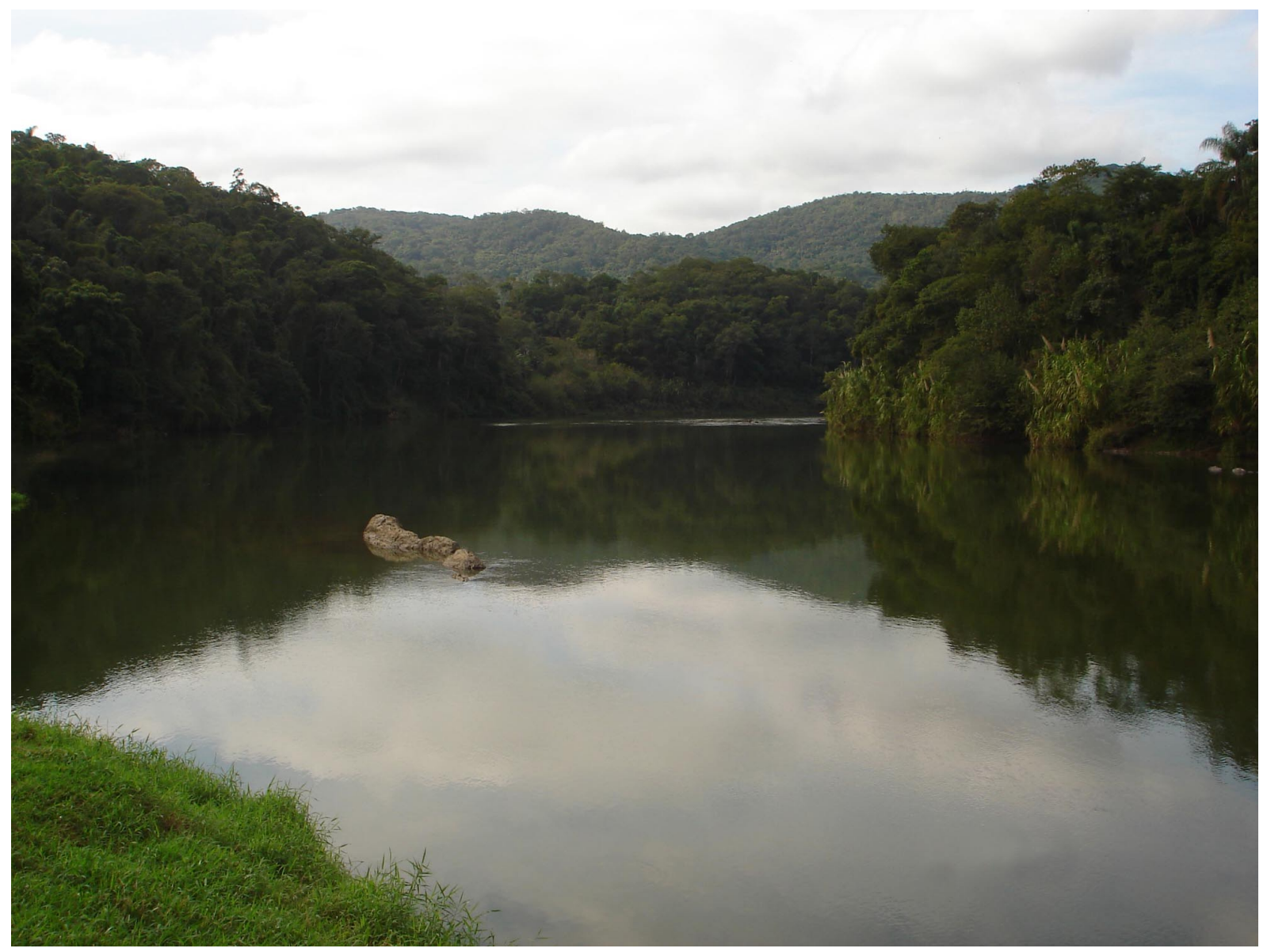

Foto: Alexandre do Nascimento Souza - 09/07/07 
O Rio Ribeira do Iguape nasce no Paraná e deságua em São Paulo. A região também conhecida como Vale do Ribeira é pobre. Os 30 municípios que conformam a bacia hidrográfica do Ribeira têm baixo IDH.

\section{Figura 2 - Principais Municípios da Bacia Hidrográfica do Rio Ribeira de Iguape}

\section{BACIA HIDROGRAFICA DO RIO RIBEIRA DE IQUAPE Principais Municipios}

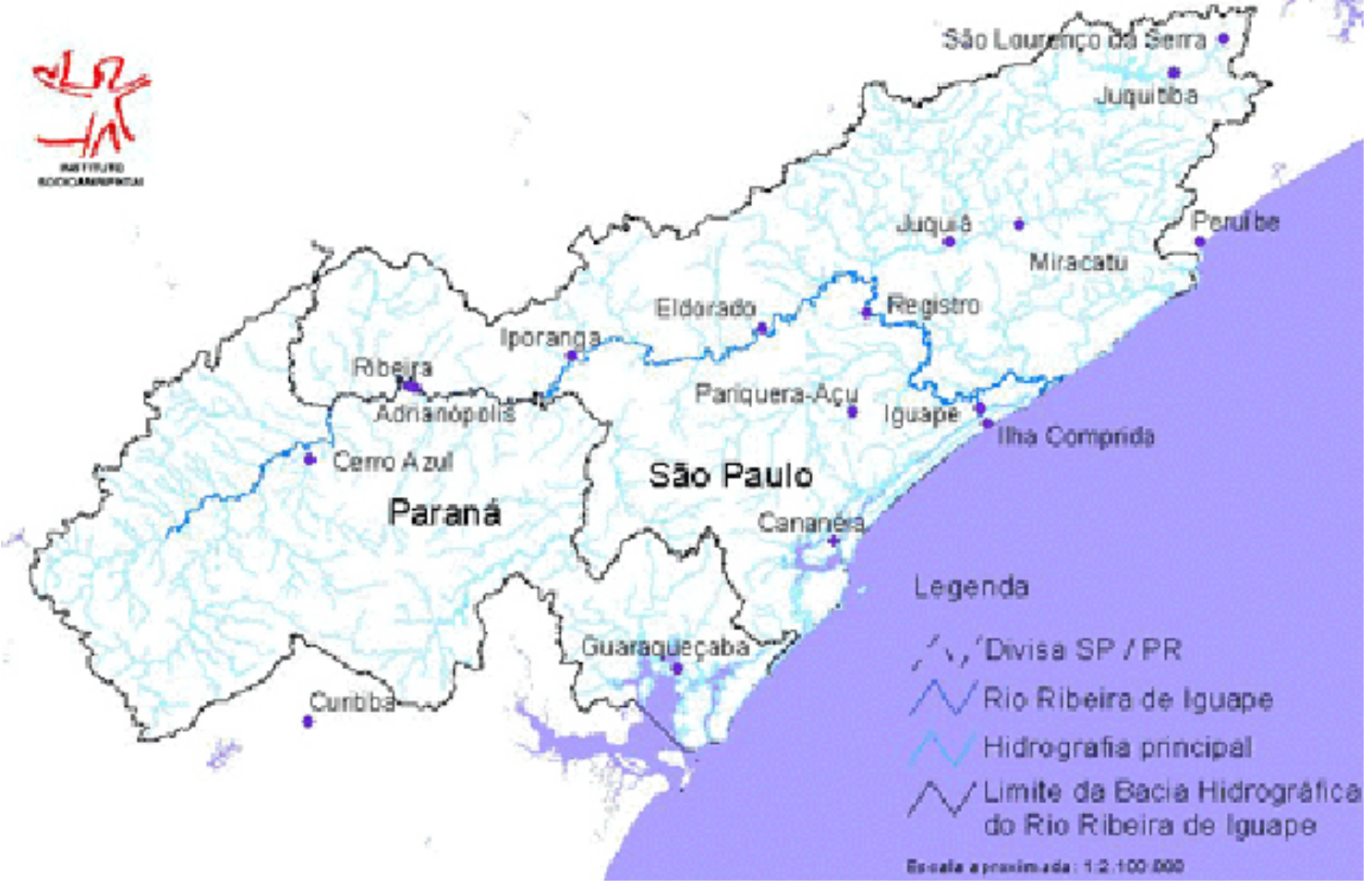

Extraído do Artigo de Juliana Moreno, “Comunidades Quilombolas do Vale do Ribeira” Fonte: Instituto Socioambiental

Historicamente, o Vale do Ribeira tem sido uma região de baixa atividade econômica. No século XVI com a exploração do ouro em Eldorado e no século XIX com a produção de arroz, a região que sempre teve limitações devidas principalmente ao terreno montanhoso, experimentou alguma prosperidade econômica.

No entanto, com o fim da atividade aurífera e o declínio da rizocultura depois da abertura do Valo Grande $^{65}$, a região tem se caracterizado principalmente pela atividade extrativista e pela agricultura

\footnotetext{
${ }^{65}$ Valo Grande é um canal que foi aberto com o intuito de facilitar o transporte de produtos para o Porto de Iguape. No entanto, houve crescente assoreamento do canal e aquilo que deveria dinamizar a atividade portuária, acabou por inviabilizá-la. Os problemas com o Valo Grande passaram a dificultar e inviabilizar o escoamento da produção de arroz.
} 
familiar. Em algumas porções do território, principalmente em São Paulo, há plantações com fins comerciais, mas a região não pode ser considerada grande produtora agrícola.

As Unidades de Conservação que estabelecem uma série de restrições ao uso do solo e a grande quantidade de conflitos de titularidade da terra têm dificultado ainda mais a atividade econômica da região que até os anos 80 esteve esquecida pelo poder público.

O Vale do Ribeira no Estado do Paraná e os municípios paulistas próximos à divisa têm características semelhantes: baixa atividade econômica, agricultura pouco mecanizada e extrativismo. Essa região pouco se comunica com os demais municípios paulistas.

No Estado do Paraná, sete municípios fazem parte da bacia hidrográfica do Ribeira: Adrianópolis, Bocaiúva do Sul, Cerro Azul, Doutor Ulysses, Itaperuçu, Rio Branco do Sul e Tunas do Paraná.

\section{Figura 3 - Municípios do Vale do Ribeira no Paraná}

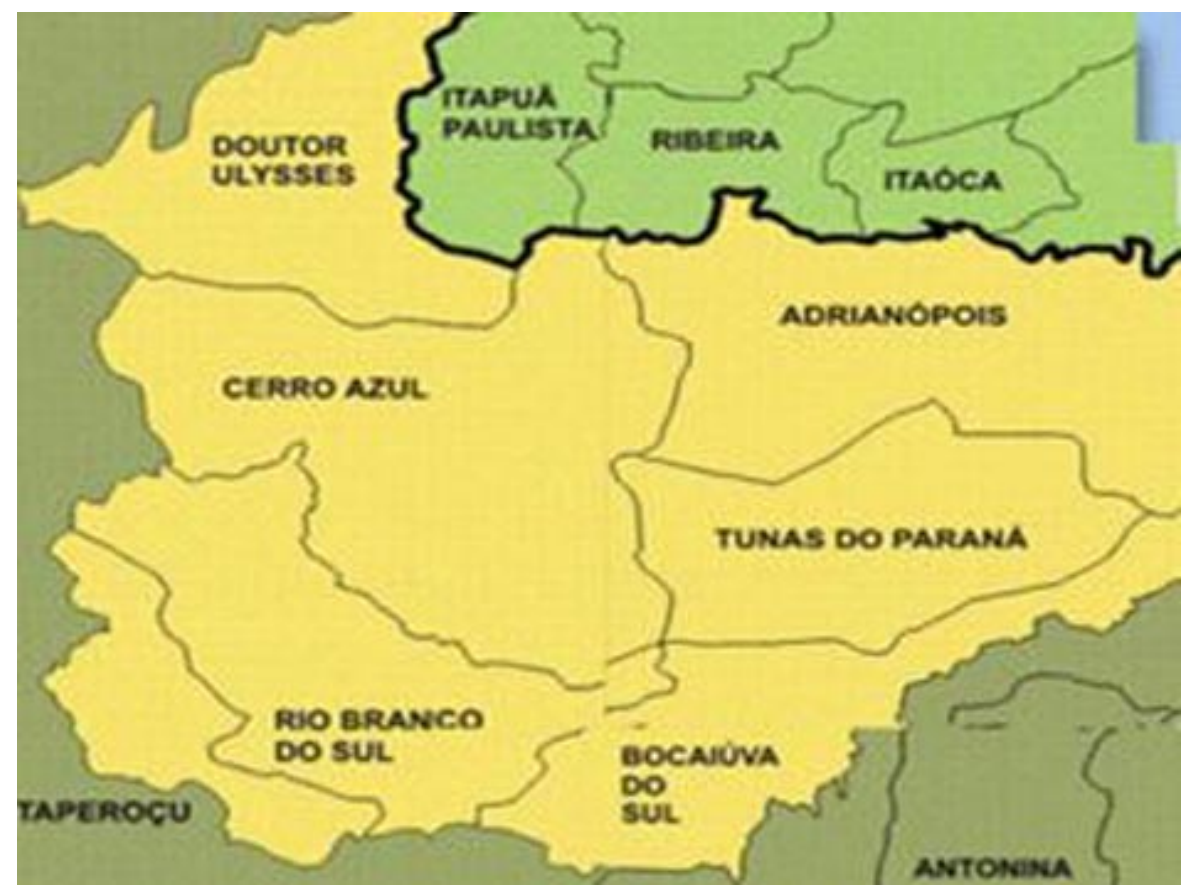

De acordo com dados do IBGE, residem nesta parte do Vale do Ribeira cerca de 90.000 habitantes, dos quais 47,64\% vivem na área rural, o IDH médio é 0,69. O Vale do Ribeira paranaense tem 5.913 agricultores familiares e 11 comunidades quilombolas. 
O Vale do Ribeira é composto por 23 municípios do lado paulista. Totaliza pouco mais de 350.000 habitantes. Reside na região uma variedade de grupos com características socioculturais peculiares. Cerca de 500 comunidades caiçaras e caipiras e remanescentes de quilombolas, além de aldeias indígenas e populações ribeirinhas, que compõem um universo populacional de mais de $35 \%$ do total de habitantes do Vale.

\section{Figura 4 - Municípios do Vale do Ribeira em São Paulo}

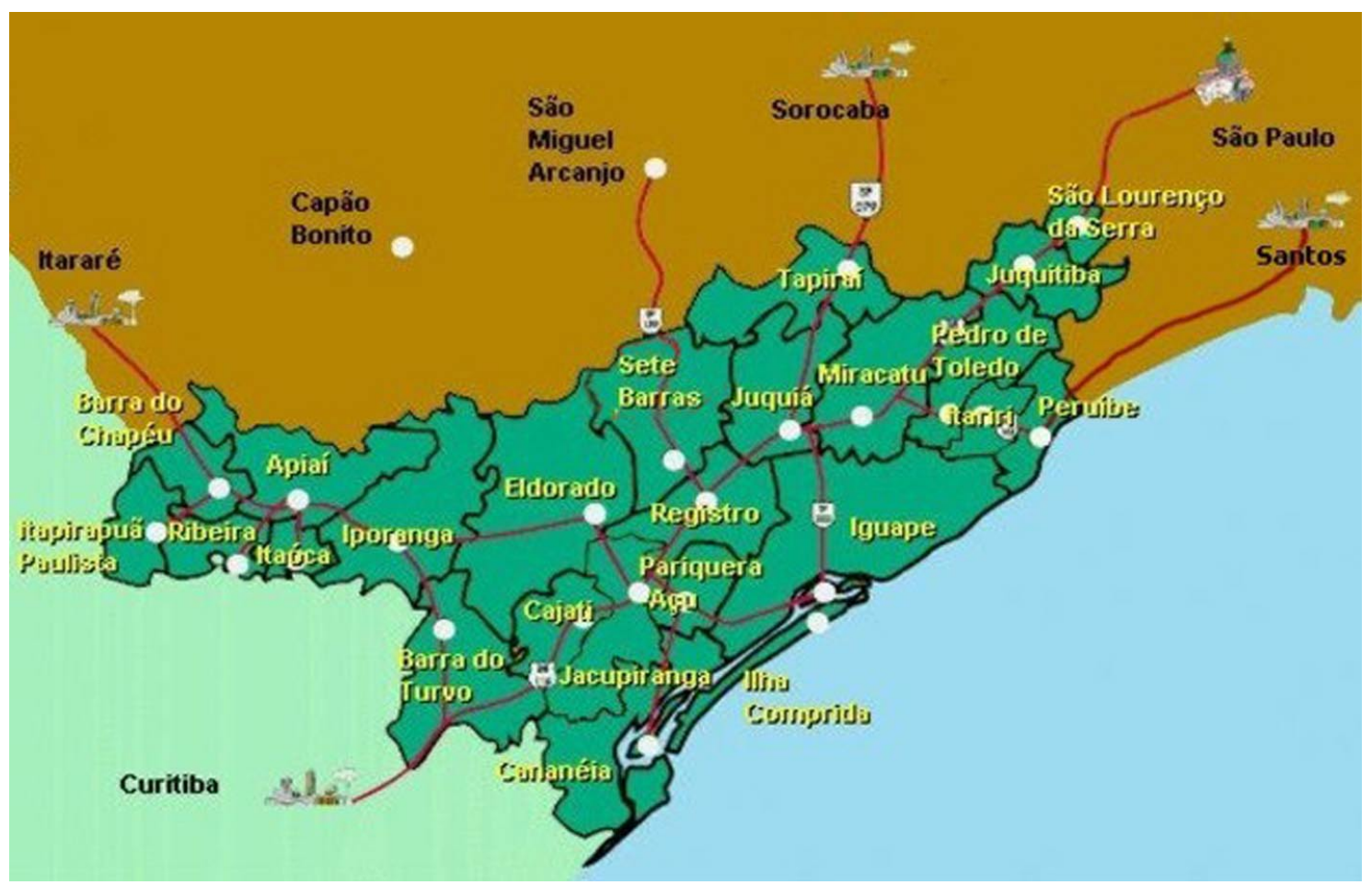

Cerca de 1,5 milhão de hectares de terra encontram-se juridicamente pendentes e em processos de regularização fundiária, o que chega a representar cerca de $40 \%$ de seu território. Em relação às áreas do Estado de São Paulo com problemas de legitimação de posse, esta representa 35\% desse total, ou seja, é a região com maior situação dominial pendente do estado. Foi historicamente palco de graves conflitos pela posse da terra envolvendo, de um lado, grileiros e seus jagunços e, de outro, os posseiros.

A riqueza ambiental da região tem sido um fator de estagnação da atividade econômica local. Por pressão de grupos ambientalistas, o poder público tem tido dificuldade de reconhecer a titularidade das terras dos pequenos proprietários e agricultores familiares, enquanto da parte do Estado, tem prevalecido "a implementação de uma política ambiental autoritária, sem promover a gestão e o planejamento para um desenvolvimento sustentável das comunidades dentro dos parques e estações”(ROMÃO, 2004, pág. 25). 


\section{Figura 5 - Atrativos Naturais do Vale do Ribeira em São Paulo}

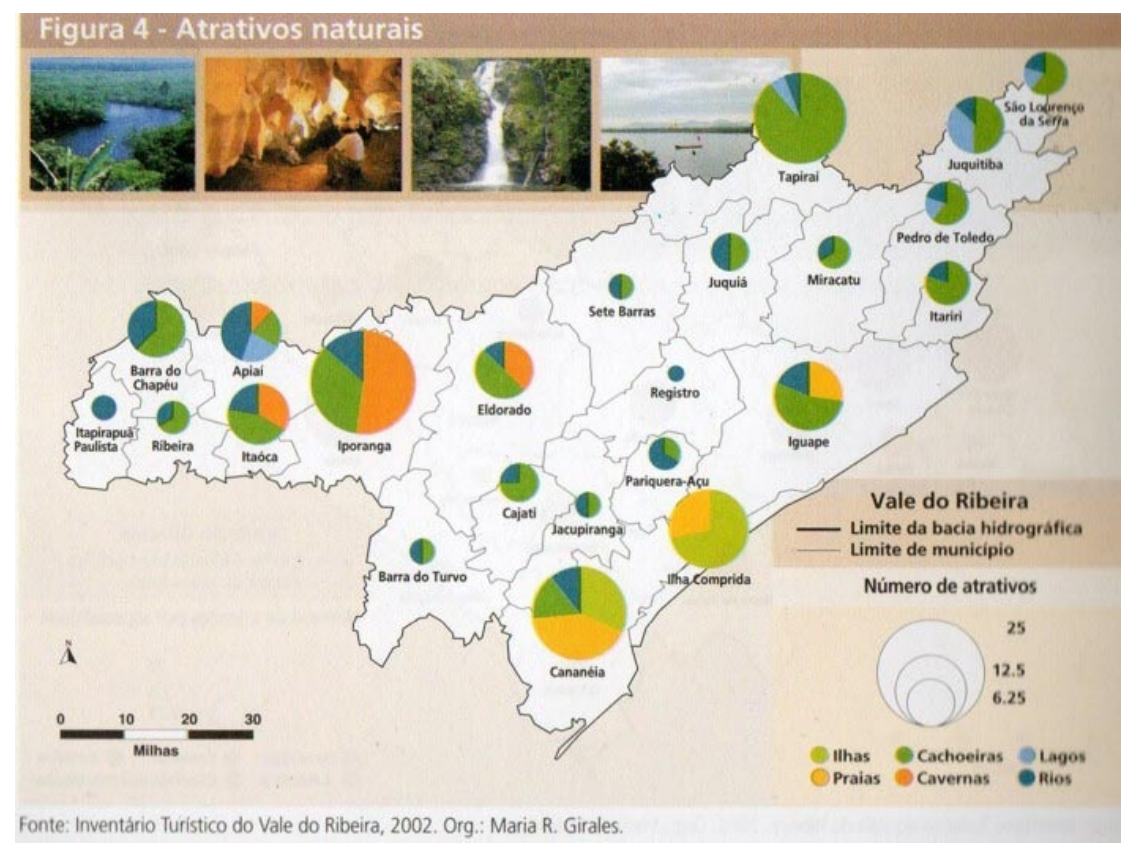

Imagem extraída de Romão Anexo Parte 3, figura 4, página 210.

Nas Unidades de Conservação Ambiental (UCAs) vivem cerca de 2.974 famílias. Os Parques Estaduais e as Estações Ecológicas são unidades de Proteção Integral, abrangem vários municípios da região, além das Áreas de Preservação Ambiental (APAs) e da Reserva da Biosfera.

\section{Figura 6 - Mapa das Unidades de Conservação do Estado de São Paulo}

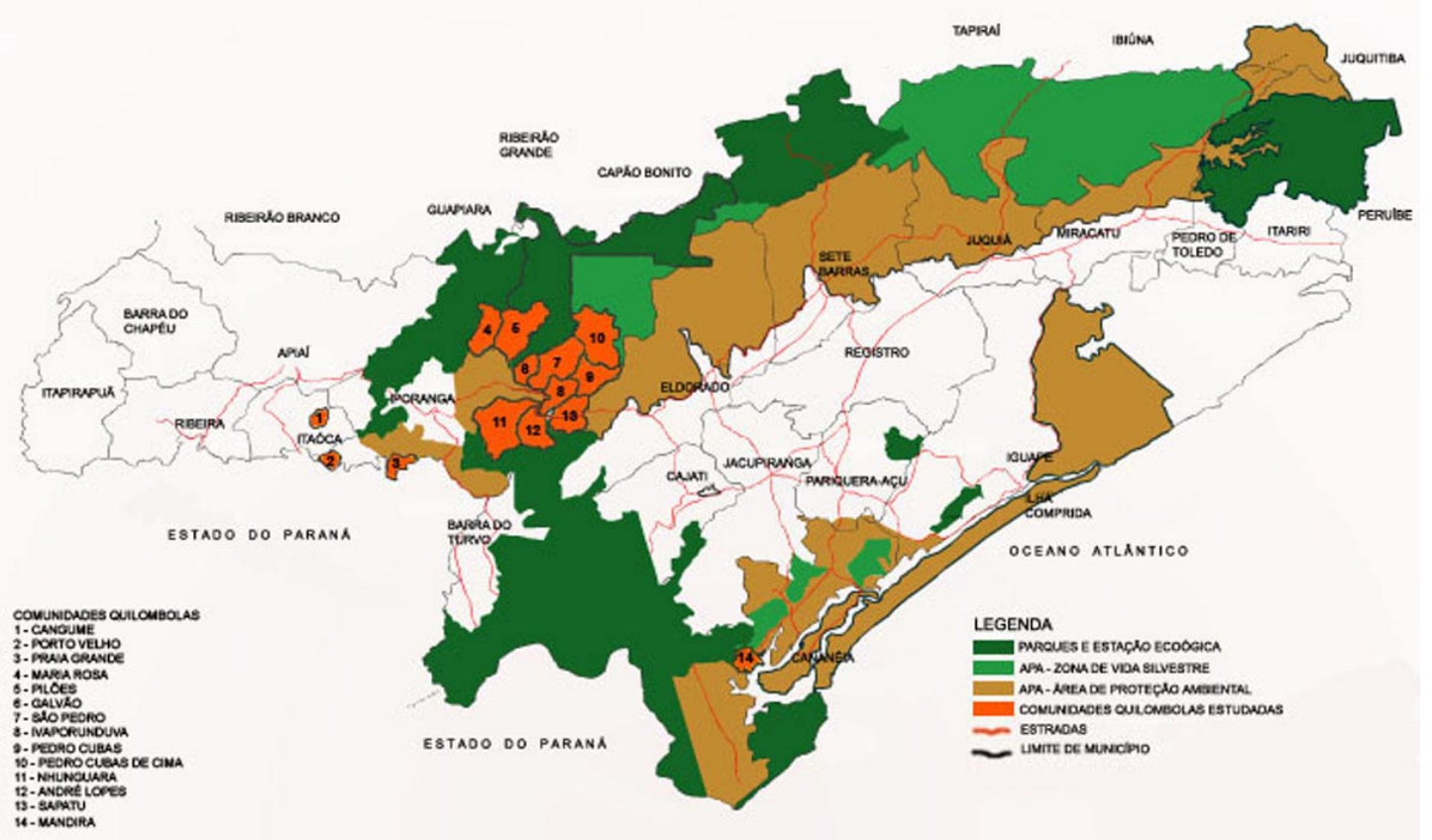

Extraído do Artigo de Juliana Moreno, “Comunidades Quilombolas do Vale do Ribeira” Fonte: Instituto Socioambiental 
Figura 7 - Mapa das Unidades de Conservação e Área de Influencia Direta da UHE Tijuco Alto

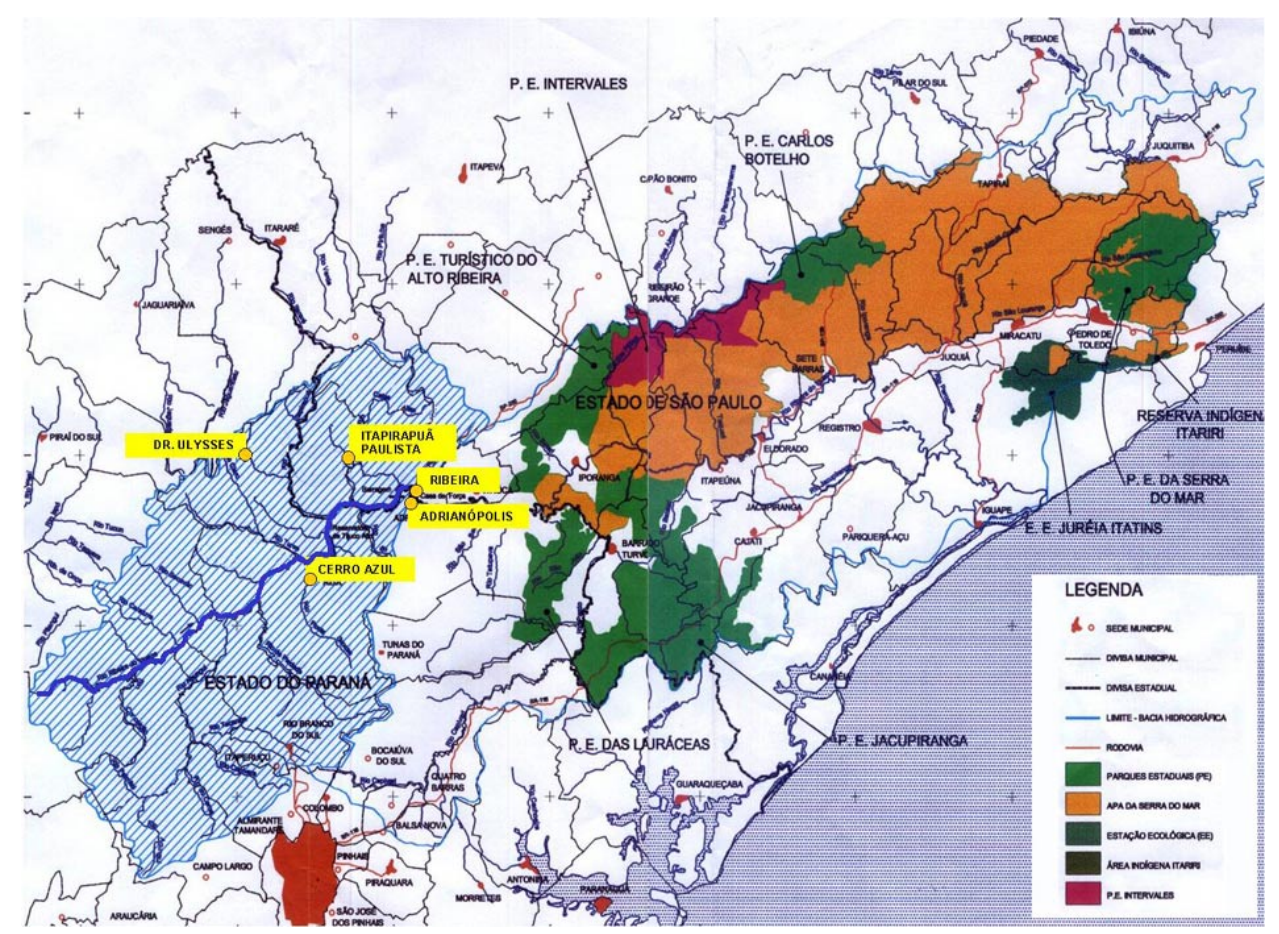

Imagem extraída de apresentação em Power Point da CNEC sobre o projeto Tijuco Alto.

A região tem ecossistemas ricos e biodiversidade da fauna e flora, além de recursos naturais importantes como as nascentes, mananciais e rios perenes.

Aregião do Vale do Ribeira está entre as mais pobres dos Estados de São Paulo e Paraná, com baixos índices de IDH.

\section{Figura 8 - Índice de Desenvolvimento Humano - São Paulo}

Índice de Desenvolvimento Humano Municipal, 2000 Municípios do Estado de Săo Paulo
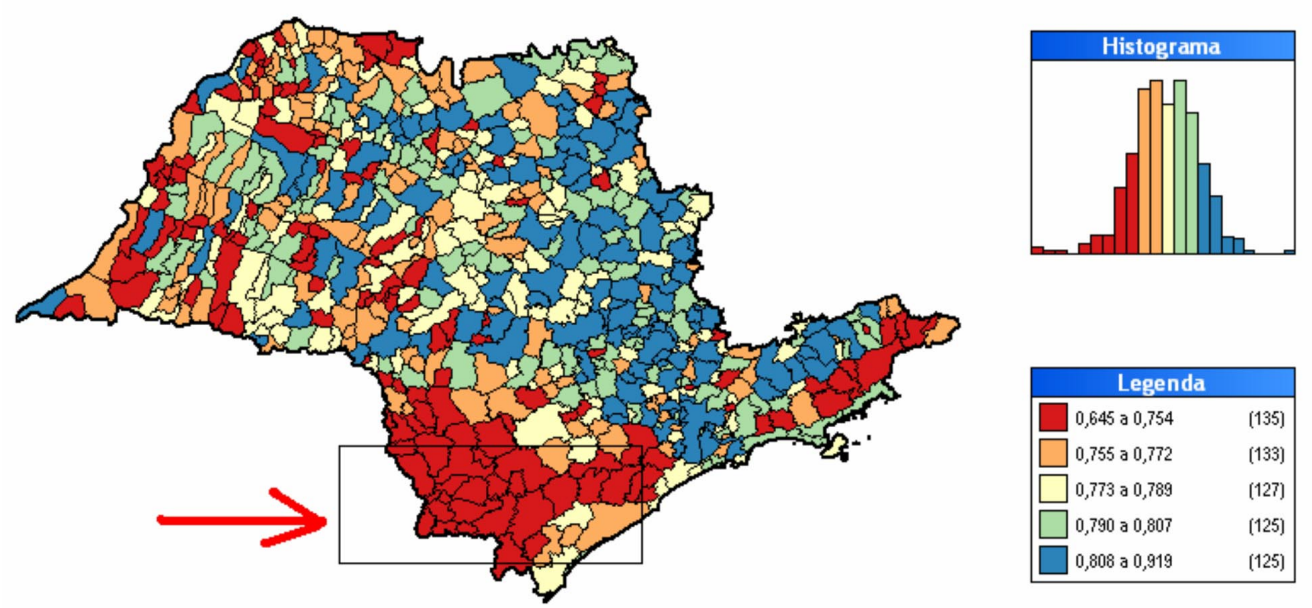

\begin{tabular}{|cc|}
\hline \multicolumn{1}{|c|}{ Legenda } \\
\hline$\square 0,645$ a 0,754 & {$[135]$} \\
$\square 0,755$ a 0,772 & {$[133]$} \\
$\square 0,773$ a 0,789 & {$[127]$} \\
$\square 0,790$ a 0,807 & {$[125]$} \\
$\square 0,808$ a 0,919 & {$[125]$} \\
\hline
\end{tabular}

Imagem extraída de apresentação em Power Point da CNEC sobre o projeto Tijuco Alto. 
Figura 9 - Índice de Desenvolvimento Humano - Paraná

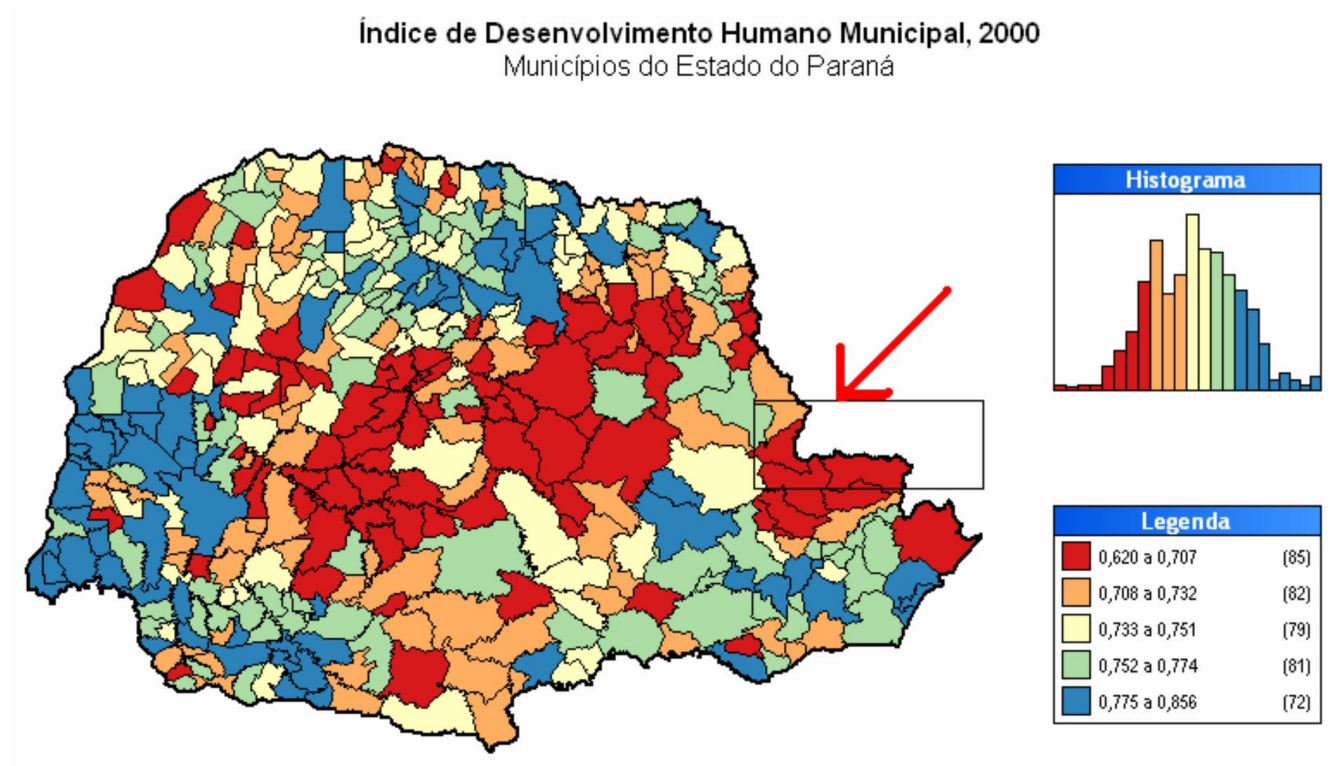

Imagem extraída de apresentação em Power Point da CNEC sobre o projeto Tijuco Alto.

Ainda assim, há diferenças socioeconômicas entre os municípios que foram divididos em 5 categorias por estudo realizado por Denise Chabaribery (2000).

Baseada em uma tipologia que parte de um diagnóstico social, econômico e ambiental dos municípios, a pesquisadora fez uma síntese das variáveis encontradas para cada um deles a partir de 5 indicadores:

1. Agricultura: Familiar ou não;

2. Indicadores de habitabilidade: eletrificação, água encanada, e educação dos chefes de familia;

3. Indicadores de dimensão das restrições ambientais para agricultura intensiva;

4. Indicadores demográficos;

5. Condições de vida: longevidade, educação, infância, renda e habitação;

Com base na análise dos indicadores, os 23 municípios foram agrupados em 5 classes: 


\section{Figura 10 - Tipologia Socioeconômica, Agrícola e Ambiental do Vale do Ribeira}

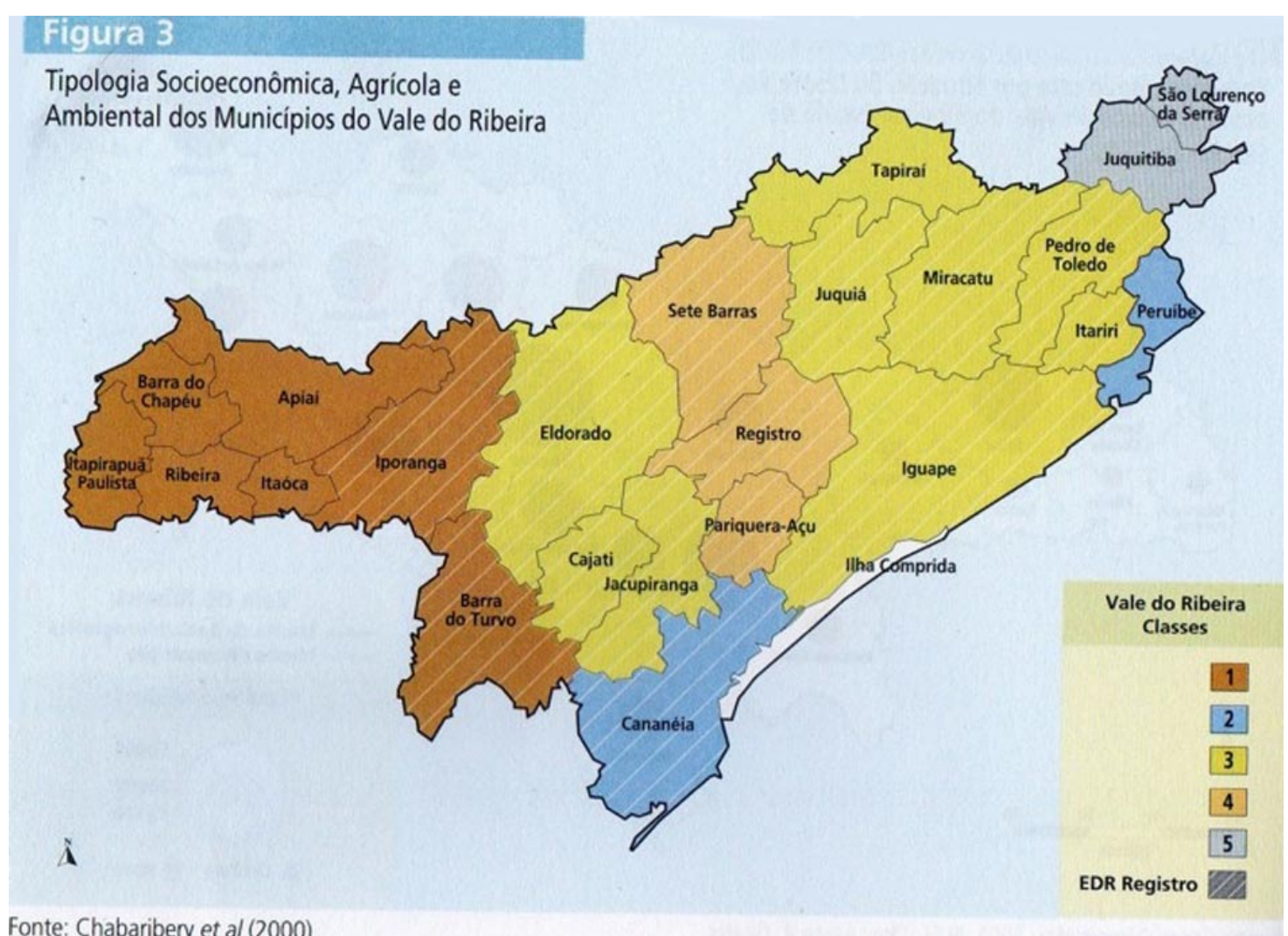

Imagem extraída de Romão Anexo Parte 1, Figura 3, pág. 158.

$1^{\text {a }}$ Classe - Apiaí, Barra do Chapéu, Iporanga, Itaóca, Itapirapuã Paulista, Ribeira e Barra do Turvo

Predomínio da agricultura familiar de baixa renda, com presença de trabalho infantil; municípios dependentes da agricultura para geração de emprego e renda, mesmo com a maior parcela de terras com restrições para a agricultura; e com vocação para a proteção da flora e da fauna. Os indicadores sociais nos domicílios rurais e de condições de vida dos municípios são os mais baixos da região, sobressaindo a precariedade da eletrificação rural e dos indicadores de educação e renda. Nessa região, também denominada Alto Vale do Ribeira, ficam os dois municípios paulistas que compõem a área diretamente afetada por Tijuco Alto, Ribeira e Itapirapuã Paulista. No Alto Ribeira, o Rio corre encaixado nas montanhas.

\section{$2^{\text {a }}$ Classe - Cananéia e Peruíbe}

A predominância das atividades pesqueiras em Cananéia e a forte influência da classe média com residências de lazer em Peruíbe mesclam-se a altos indicadores de modernização agrícola e de condi- 
ções de habitação e renda, com indicadores sociais não muito bons. Os ligados à educação são ruins, tanto os referentes aos chefes de domicílio rural predominantemente analfabetos, quanto os que retratam as condições educacionais das crianças. É o grupo de municípios que têm menor dependência da agricultura para a geração de emprego.

$3^{\text {a }}$ Classe -Eldorado, Juquiá, Miracatu, Jacupianga, Tapiraí, Cajati, Iguape, Itariri e Pedro de Toledo

É o grupo de municípios que mais se aproxima da média regional de produção agrícola. Tem predomínio da agricultura familiar com baixos índices de modernização agrícola, mas demonstra capacidade produtiva da força de trabalho nos seus sistemas produtivos, basicamente a fruticultura. As condições de vida são péssimas em relação à educação. Este conjunto de municípios fazem parte do Médio Vale do Ribeira e parte dos remanescentes de quilombo da região concentram-se nesta região.

$4^{\text {a }}$ Classe - Registro, Sete barras e Pariquera-açu

Pólo de crescimento capitalista do Vale, no qual a agricultura familiar é importante, mas as culturas de chá e banana empregam muitas pessoas. Registro é considerada a capital econômica do Vale, e Pariquera-Açu para onde converge boa parcela da demanda da região por equipamentos públicos de Saúde. Nesta região o Rio Ribeira corre sobre a planície.

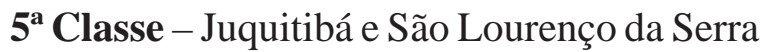

Municípios considerados como pertencentes ao Vale do Ribeira por estarem nos limites hidrográficos do Rio Ribeira, mas, de fato, localizam-se na região metropolitana de São Paulo.

A partir do estudo de Chabaribery pode-se afirmar que os municípios da classe 1, onde estão os municípios diretamente afetados pela UHE, são os mais pobres e carentes da região e os da classe 5 estão medianamente situados. No campo intermediário, a classe 2 é de cidades litorâneas relacionadas ao turismo de veraneio e as classes 3 e 4 seriam os representantes da média da região.

O Vale do Ribeira apresenta graus diferentes de pobreza. Há heterogeneidade no quadro de carências da região. Constata-se o predomínio da agricultura familiar de baixa renda. Nas classes 2 e 5, há predominância da agricultura patronal em relação a produção de sub-existência. Apesar de não serem 
municípios tipicamente agrícolas, apresentam características de cidades com modo de vida urbano.

A restrição à atividade agropecuária em grandes extensões de seus territórios é um traço comum a todas essas classes de municípios.

Com exceção dos municípios da classe 2 , que têm no turismo de veraneio uma importante atividade econômica, os demais dependem da agricultura para a geração de emprego e de renda, fato que está também relacionado ao baixo dinamismo econômico da região, colocando-a na dependência das atividades rurais para a população.

\subsection{O MOVIMENTO SOCIAL NO VALE DO RIBEIRA - BREVE DESCRIÇÃO}

A presença do movimento social na região do Vale do Ribeira é representativa das condições sociais e econômicas sistematizadas pelo estudo acima apresentado.

Durante o ciclo de audiências públicas referentes ao aproveitamento hidrelétrico de TijucoAlto foram raros os posicionamentos públicos de cidadãos, políticos e organizações políticas e sociais situadas na parte mais pobre do Vale do Ribeira e onde está proposto o barramento do aproveitamento hidrelétrico Tijuco Alto.

A participação de pessoas originárias dos municípios da área de influência foi reduzida, e quando ocorreu, se deu nas audiências do próprio município. Ao contrário dos participantes de municípios de fora da área de influência, que intervieram em todas as plenárias.

Basicamente a representação política tradicional: deputados estaduais, prefeitos, vice-prefeitos e vereadores dos municípios localizados na área de influência direta - $\mathrm{AID}^{66}$ se posicionou nos debates referentes à possibilidade de se construir a UHE.

Os movimentos sociais que participaram das audiências públicas, e que normalmente se posicionaram contrariamente $^{67}$ à construção da UHE proposta pela CBA, estão localizados e têm sua área de

\footnotetext{
${ }^{66}$ A Área de Influência Direta foi definida como a área sujeita aos impactos diretos da implantação e operação do empreendimento, levando-se em conta as características sociais, econômicas, físicas e biológicas dos sistemas estudados e das particularidades da hidrelétrica. Compreende os municípios de Ribeira e Itapirapuã Paulista no Estado de São Paulo e Adrianópolis, Cerro Azul, Dr. Ulysses e Rio Branco do Sul no Estado do Paraná.

${ }^{67}$ A exceção foi a Associação de Bananicultores do Vale do Ribeira - ABAVAR, que se posicionou favorável ao empreendimento.
} 
atuação fora da AID. A área de influência direta da hidrelétrica está localizada na parte com menor dinâmica econômica da região, na divisa entre os estados de São Paulo e Paraná.

As entidades do movimento social que gravitam em torno da discussão do licenciamento da UHETijuco Alto localizam-se ou nos municípios situados no Médio Vale do Ribeira e na foz do rio, como o MOAB, IDESC, ABAVAR e Coletivo Educador de Cananéia, ou são originariamente de fora do Vale, normalmente São Paulo, mas desenvolvem programas e projetos na região, como o ISA, SOS Mata Atlântica e MST.

\section{$\underline{\text { OMOAB }}$}

Tanto o Movimento dos Ameaçados por Barragens como a organização política das comunidades quilombolas, tiveram suas origens na oposição à construção das hidrelétricas previstas para o Rio Ribeira, mais especificamente para se contrapor a UHE proposta pela CBA $^{68}$. Além de Tijuco Alto existem outros três aproveitamentos hidrelétricos previstos para o curso do Rio Ribeira - Itaóca, Funil e Batatal.

Figura 11 - Mapa das UHE‘s inventariadas para o Rio Ribeira e extensão das áreas alagadas

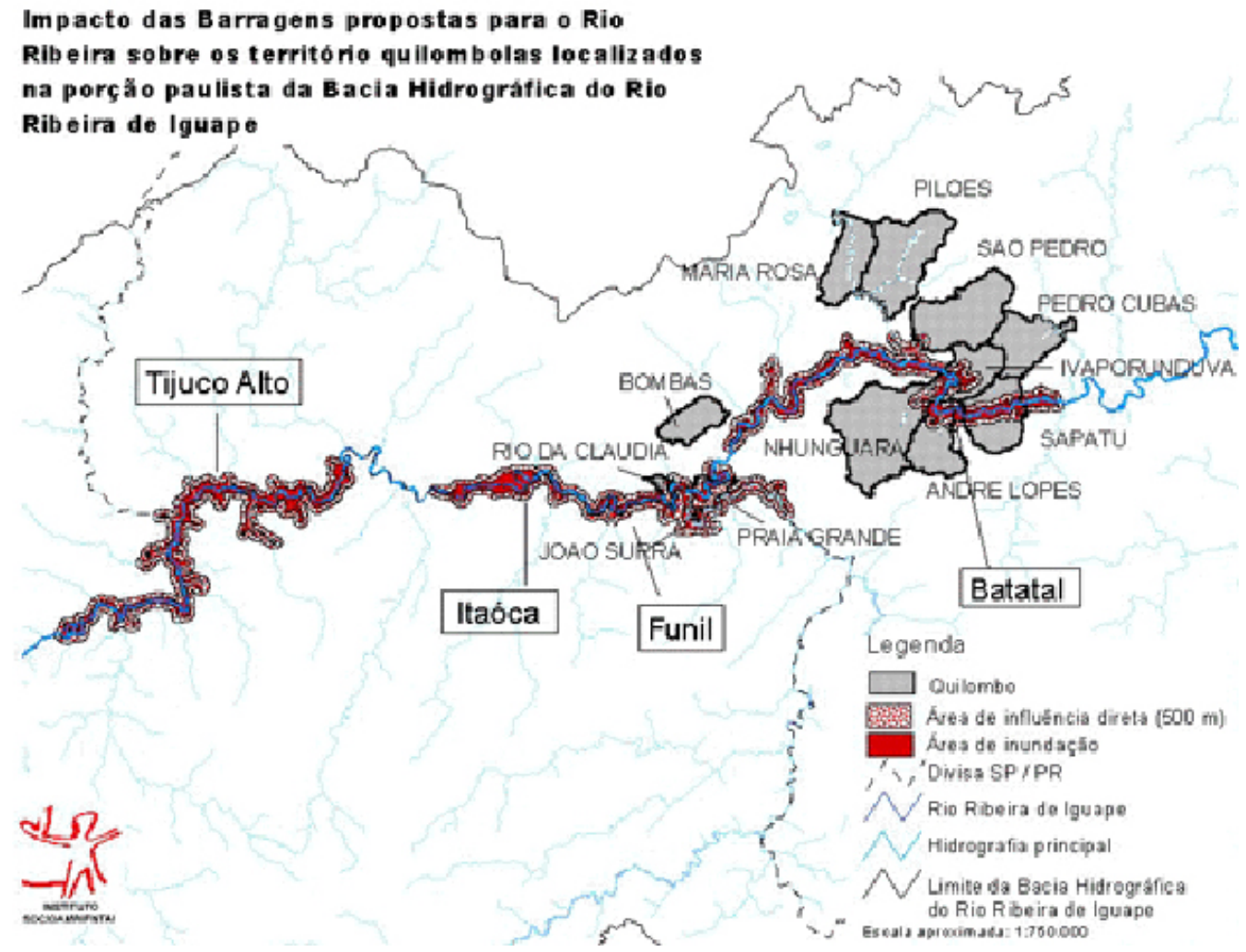

Extraído do Artigo de Juliana Moreno, "Comunidades Quilombolas do Vale do Ribeira” Fonte: Instituto Socioambiental 
O aproveitamento Tijuco Alto, fica no Alto Ribeira, portanto a montante dos demais. A UHE em licenciamento não irá alagar área quilombola, no entanto, com a construção de Tijuco Alto, as outras três UHEs ganham viabilidade técnica. E, se construídas, irão alagar terras das comunidades remanescentes de quilombos no caso da UHE Batatal ou os quilombos estarão na área de influência direta dos empreendimentos, caso da hidrelétrica Funil. A oposição do MOAB e das comunidades à hidrelétrica Tijuco Alto têm sua origem nesse fato.

A sede do MOAB fica em Eldorado. O município é próximo de inúmeras comunidades quilombolas do Médio Ribeira. As principais lideranças do movimento são oriundas das comunidades quilombolas e da Igreja Católica.

\section{IDESC}

Em Registro ficam as estruturas administrativas do Comitê de Bacia Hidrográfica do Vale do Ribeira e o IDESC, ONG socioambiental com forte atuação na região e que articula o CONSAD, um Consórcio de Segurança Alimentar, constituído pelos municípios e instituído em 2007, por ocasião do Programa de Segurança Alimentar e Desenvolvimento Local, feito no âmbito do Ministério do Desenvolvimento Social entre os municípios do Vale do Ribeira do Estado de São Paulo.

O IDESC tem como foco de sua atuação o desenvolvimento sustentável, e possui quadro militante bastante eclético - empresários e profissionais com extensa atuação nos movimentos social, sindical, popular e ambiental.

Além do CONSAD a ONG articulou os debates que conformaram a AGENDA 21 do Vale do Ribeira, e desenvolve projetos socioambientais com jovens da região. Uma das fundadoras dainstituição, Sandra Keneddy, foi eleita prefeita do município de Registro pelo Partido dos Trabalhadores nas eleições municipais de 2008.

\section{Coletivo Educador do Lagamar}

Nas audiências de Eldorado e Registro outro grupo social que demonstrou força e capacidade de mobilização semelhante ao MOAB foi o Coletivo Educador do Lagamar, sediado em Cananéia e

\footnotetext{
${ }^{68}$ No RIMA elaborado para Tijuco Alto, a organização das comunidades e do MOAB para se contrapor a construção da UHE é apresentado como um impacto positivo do empreendimento.
} 
que também protagonizou resistência a UHE durante todas as plenárias, mas que nas duas últimas trouxe ônibus de militantes, a exemplo do que fizera o MOAB em Cerro Azul e Eldorado principalmente, e com menor quantidade de pessoas em Registro. O coletivo Lagamar levou mais militantes na audiência de Registro.

O Coletivo se diferenciou dos demais grupos devido ao fato de ser composto majoritariamente por jovens e, de alguma forma, liderado não só, mas também por pessoas recém pós-graduadas nas universidades públicas do Estado de São Paulo. Depois do ciclo de audiências articulou debates na USP, Unicamp e em alguns espaços de militância social protagonizados por jovens na cidade de São Paulo, quando buscaram arregimentar apoios à oposição da concessão da licença ambiental a Tijuco Alto.

Durante o ciclo de audiências públicas do licenciamento da UHE, a principal característica das intervenções do grupo foi a recorrência a estudos científicos desenvolvidos nas universidades paulistas para legitimar suas intervenções.

Na audiência de Registro, quando o grupo se fez mais numeroso, mobilizou estudantes do ensino médio, comunidades ribeirinhas e (comunidades) indígenas.

\section{Instituto Socioambiental-ISA}

O ISA ${ }^{69}$ atua na Bacia Hidrográfica do Rio Ribeira e no Complexo Estuarino Lagunar de IguapeCananéia- Paranaguá. A instituição considera esta faixa a mais importante área de Mata Atlântica remanescente do Brasil e estratégica não só pela sua sociobiodiversidade e conservação das florestas, mas também porque o Rio Ribeira é um manancial de água para a região metropolitana de São Paulo.

Os projetos da ONG buscam integrar economicamente as comunidades tradicionais a partir da manutenção do potencial hídrico da região e de sua sociobiodiversidade.

O ISA tem uma sede avançada em Eldorado. A ONG ambientalista desenvolve projetos em parceria com as comunidades quilombolas.

\footnotetext{
${ }^{69} \mathrm{O}$ Vale do Ribeira tem importância estratégica às atividades da ONG que tem cerca de 9 iniciativas distintas de intervenção socioambiental, articuladas pelo "Programa Vale do Ribeira". http://www.socioambiental.org/prg/rib.shtm
} 


\section{SOS Mata Atlântica}

AONG ambientalista SOS Mata Atlântica tem reconhecida militância no país em defesa do bioma que carrega no nome. Dois de seus militantes participaram ativamente das audiências públicas de Tijuco Alto.

A organização não governamental desenvolve em parceria com uma rede de escolas e instituições locais um projeto de observação da qualidade da água do Rio Ribeira.

A SOS Mata Atlântica participou ativamente do primeiro processo de licenciamento de Tijuco Alto, mas no segundo licenciamento atuou basicamente nas audiências públicas.

\section{CEDEA}

O Centro de Estudos, Defesa e Educação Ambiental foi a única instituição da sociedade civil com origem no Estado do Paraná que participou das cinco audiências públicas do licenciamento da hidrelétrica proposta pela CBA.

A representante da instituição, Laura Jesus teve participação ativa no ciclo de audiências no qual chamou atenção para o fato de que há risco na formação do lago devido ao solo Kárstico da região.

\section{$\underline{\text { MST }}$}

O Movimento dos Sem Terra tem abrangência nacional e ocupa-se da luta contra a concentração fundiária e para ampliar o acesso dos trabalhadores rurais à terra.

Durante o ciclo de audiências teve participação no debate através de um grupo de jovens ligados ao movimento e que estavam acampados no município de Apiaí.

\subsubsection{O Aproveitamento Hidrelétrico de Tijuco Alto e o Movimento Social no Vale do Ribeira}

Durante os 20 anos que perdura a discussão sobre o licenciamento da UHE proposta pela Companhia Brasileira de Alumínio, ao mesmo tempo em que o movimento social no Brasil se fortaleceu e ganhou maior protagonismo (TATAGIBA, 2002), a oposição à construção da hidrelétrica contribuiu para o surgimento, crescimento e fortalecimento do movimento social no Vale do Ribeira. 
A oposição à hidrelétrica possibilita as entidades dialogar com amplas parcelas da população ${ }^{70}$, por um lado, e por outro, se constituiu como pauta de consenso do movimento social. Essa agenda em comum a todo movimento social tem servido como cortina de fumaça das diferenças políticas e de visão de sociedade, entre alguns atores sociais entre si.

A situação contribuiu para a popularização e conseqüente fortalecimento do movimento social que tem desenvolvido inúmeras ações conjuntas em defesa do Rio Ribeira, pelo desenvolvimento sustentável da região e contrárias a UHE.

Além do amplo movimento durante o primeiro licenciamento da hidrelétrica que acabou na negativa do IBAMA, durante o segundo processo de licenciamento iniciado em 2004, uma série de ações tem sido desenvolvidas pelas entidades da sociedade civil local e em parceria com instituições de fora do Vale do Ribeira.

Em março de 2006, por ocasião da reunião da COP-8 em Curitiba os grupos sociais do Vale do Ribeira contrários a UHE engrossaram o ato em favor da agricultura familiar e contrário a construção de Tijuco Alto.

Na ocasião, foi encaminhada carta a então Ministra do Meio Ambiente, Marina Silva e ao governador do Paraná Roberto Requião, na qual as entidades signatárias expressaram contrariedade quanto à possibilidade de construção da usina ao longo do rio Ribeira e alertaram para a importância do Vale do Ribeira na conservação da diversidade, já que a região abriga a maior área contínua e preservada de Mata Atlântica do Brasil.

O documento afirmava que a usina inundará corredores ecológicos e expulsará agricultores. "Não precisamos de mais alumínio, mas de mais dignidade para os agricultores familiares, quilombolas, indígenas e pescadores", escreveram.

Em março de 2007 o movimento em defesa do Rio Ribeira realizou o ato “Terra Sim! Barragem Não!’. A caminhada ocorreu na BR 116 por 9 KM.

\footnotetext{
${ }^{70}$ Entre os atores sociais do Vale do Ribeira, há consenso em torno da idéia de que o longo processo de licenciamento permitiu que um número crescente de pessoas se informasse sobre o empreendimento e que o apoio a construção da UHE diminuiu a medida que foi passando o tempo.
} 
Em julho de 2007, houve ato público em defesa da aprovação do Projeto de Lei apresentado pelo deputado estadual do PSOL, Raul Marcelo, que propôs o tombamento do Rio Ribeira do Iguape como patrimônio histórico, cultural e ambiental do Estado de São Paulo. O movimento social do Vale do Ribeira encabeçou a mobilização e trouxe inúmeros ônibus com manifestantes favoráveis a aprovação do PL 394/07 que foi aprovado no plenário da Assembléia, mas vetado pelo governador José Serra.

Em março de 2008, o movimento contrário a UHE Tijuco Alto ocupou a sede do IBAMA em São Paulo a fim de negociar abertura do diálogo a respeito do licenciamento da hidrelétrica.

O discurso dos ocupantes estava ancorado nos ofícios encaminhados pelo MOAB antes da definição do termo de referência, no qual solicitavam a abertura de canal de diálogo e como não foram contemplados naquele momento, mesmo depois das Audiências Públicas reivindicaram que o IBAMA os ouvisse antes de tomar a decisão final sobre o empreendimento.

André Murtinho ${ }^{71}$, ligado ao Coletivo Educador do Lagamar e que compôs a comissão que negociou com a Gerência do IBAMA em São Paulo, chamou atenção para o fato de que durante anos foram feitos inúmeros atos e tentativas de estabelecimento de diálogo com o IBAMA e só depois de ocupada a sede do órgão em São Paulo, isso foi conseguido.

José Rodrigues, presidente do MOAB afirmou que o EIA produzido pela CBA/CNEC tem má qualidade e por isso o ato daquele dia solicitava que o IBAMA ouvisse o parecer do movimento social, que é contrário a Tijuco Alto.

Nilton Tato, Coordenador do Programa Vale do Ribeira do ISA, também compôs a comissão negociadora e assim como Murtinho criticou o fato de que foi preciso ocupar a sede do órgão para que o movimento social, ONGs e contrários a UHE Tijuco Alto pudessem ter uma agenda de discussão com o IBAMA.

O resultado da ocupação foi a abertura de canal de diálogo entre o IBAMA e o movimento social do Vale do Ribeira em relação a UHE. O órgão de licenciamento se comprometeu a realizar um debate

\footnotetext{
${ }^{71}$ As falas de André Murtinho, José Rodrigues e Nilton Tatto foram colhidas em entrevista realizada minutos após o término do acordo entre a gerência do IBAMA em São Paulo e o movimento contrário a licença da UHE.
} 
público no Vale do Ribeira para que todas as pendências em relação ao empreendimento fossem discutidas $^{72}$.

A oposição a Tijuco Alto articula o movimento social dentro e fora do Vale. Além de entidades ambientalistas e lideranças políticas fazem parte da rede núcleos e projetos ligados a universidade, como o Programa Comunidades Quilombolas, ligado a Unicamp e com grande atuação junto as comunidades do Vale do Ribeira.

Mesmo quando as parcerias entre entidades do Vale do Ribeira e outras de fora acontecem em torno de algum projeto ou atividade que não envolva a oposição à construção da UHE, há uma espécie de solidariedade das pessoas e instituições que são de fora da região, de modo que toda atividade desenvolvida para manifestar contrariedade ao empreendimento, sempre conta com a participação desses atores e entidades que aproveitam para hipotecar seu apoio à luta do movimento social contrário ao projeto da CBA.

Ainda que a maioria iminente das instituições localizem-se a jusante de onde se pretende construir a barragem, a ação contínua dessas instituições e durante tão longo período de tempo teve como resultado a perda de apoio à construção da UHE por parte de parcela da população do Vale do Ribeira.

Essa opinião é compartilhada não só por aqueles contrários à hidrelétrica, como o prefeito de Ribeira, Jonas Batista, mas também por Ronaldo Crusco ${ }^{73}$ que em entrevista afirmou que a posição favorável a Tijuco Alto havia perdido a batalha da comunicação e que isso se devia principalmente ao fato de que durante todo o período no qual se arrasta o licenciamento, o movimento social contrário esteve cotidianamente fazendo o debate com a população local, a partir do ponto de vista que lhe interessava.

\footnotetext{
${ }^{72}$ Até fevereiro de 2009 não havia sido realizado o debate e nem data marcada.

${ }^{73}$ Ronaldo Crusco coordena a equipe de consultores da CNEC que elaborou o EIA de Tijuco Alto e foi entrevistado no dia 04/09/07 e Jonas Batista no dia 08/07/07.
} 
Figura 12 - Agricultores familiares, ambientalistas e simpatizantes das questões ambientais se manifestam em favor da agricultura familiar e contrários a UHE Tijuco Alto durante abertura da COP-8 em Curitba

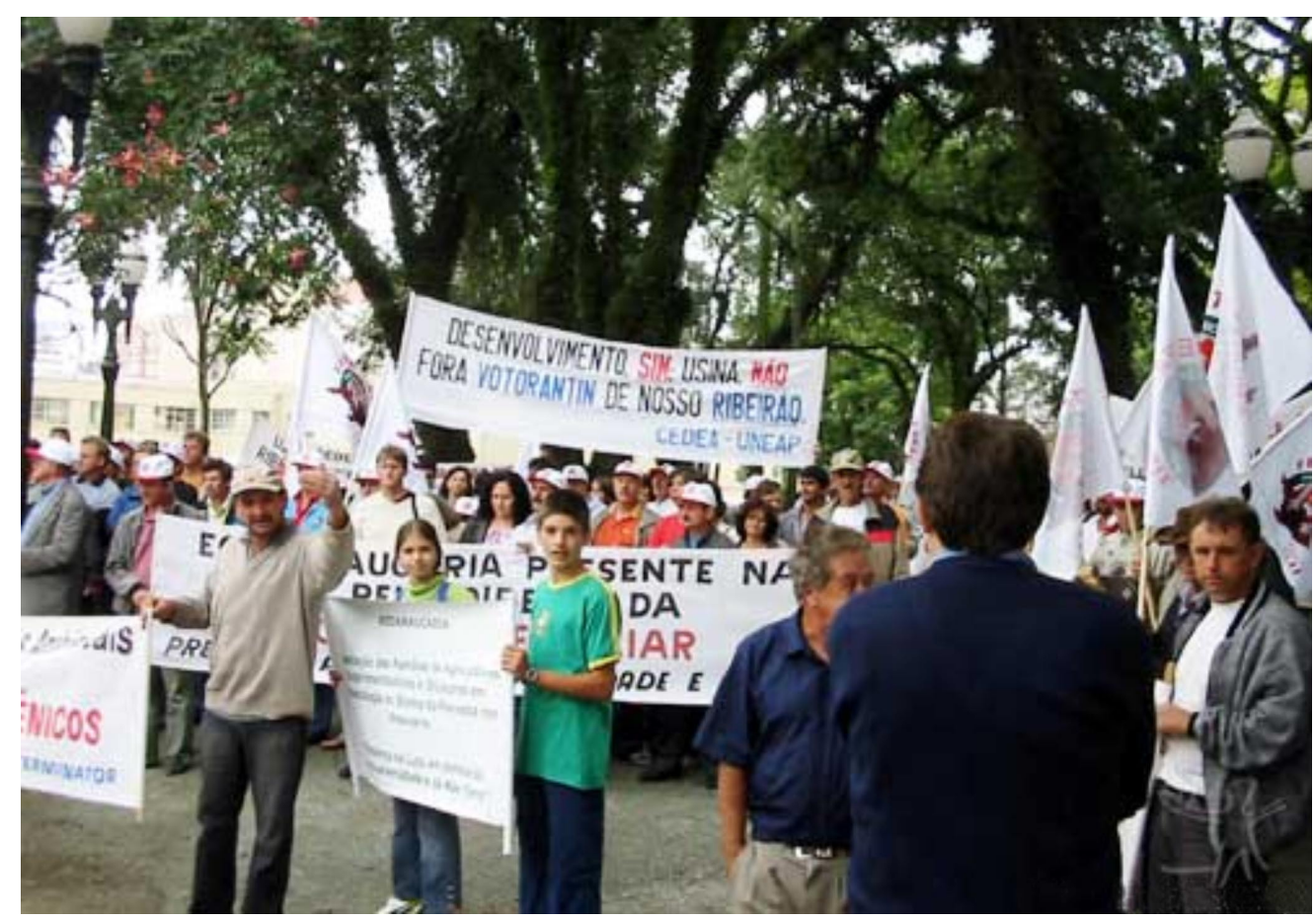

Foto: Maria Inês Zanchetta/ISa

Figura 13 - Movimento Social contrário a UHE Tijuco Alto ocupa sede do IBAMA em São Paulo e reivindica diálogo

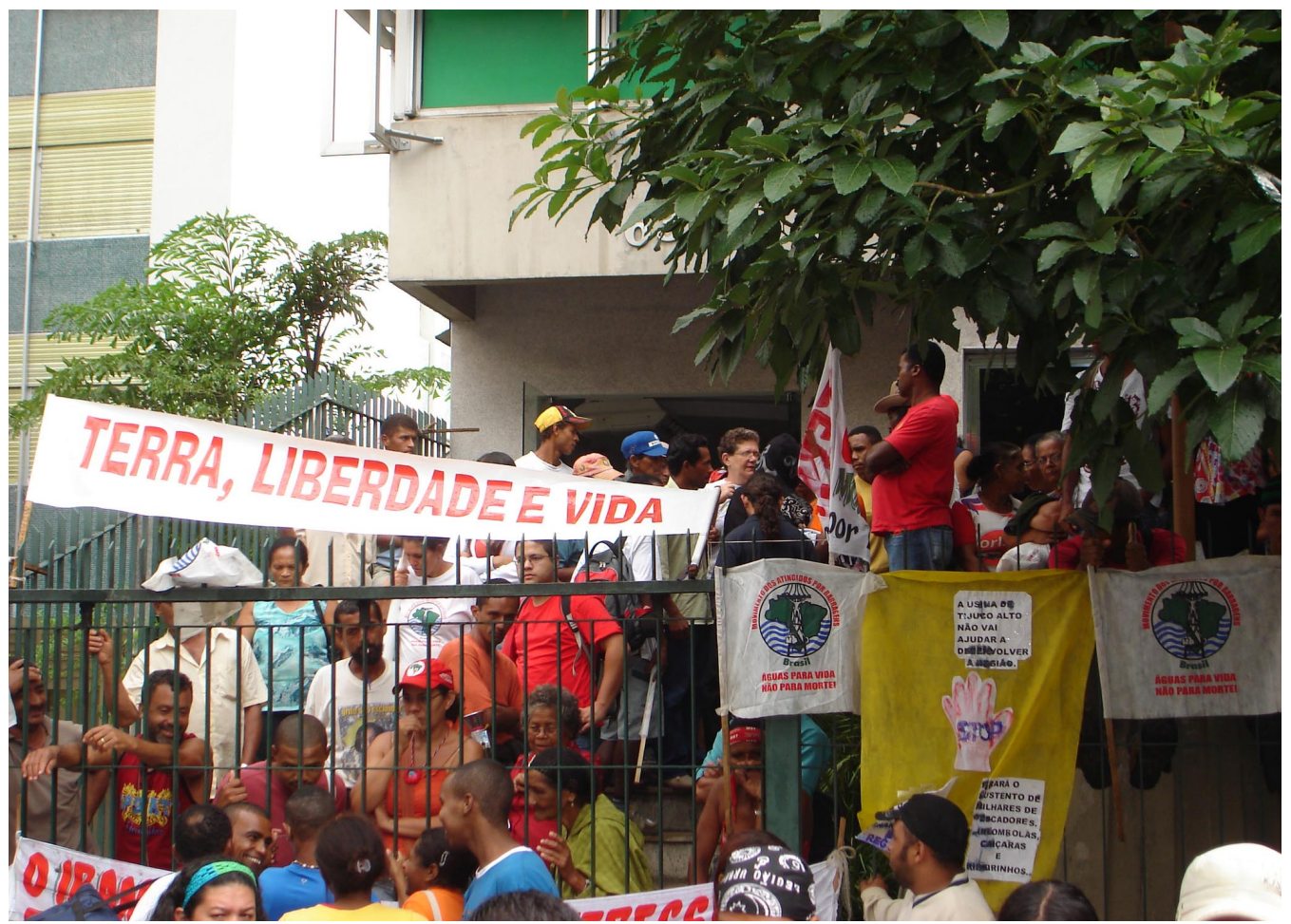

Foto: Alexandre do Nascimento Souza - 12/03/08 


\subsection{PORQUE TIJUCO ALTO É TÃO IMPORTANTE PARAA CBA?}

\subsubsection{A indústria de Alumínio no Mundo: breve panorama}

A produção de alumínio se realocou nas últimas décadas do século passado em busca de melhores cenários produtivos. Adependência do insumo energia, central no processo produtivo, e o quadro de escassez crescente dos recursos energéticos em boa parte do planeta tencionaram para que as indústrias de alumínio buscassem locais mais favoráveis a seu processo produtivo-disponibilidade de jazidas e ou potencial hidrelétrico.

Nos últimos 40 anos houve mudanças no ranking de países produtores de alumínio primário. Conforme o quadro 11, os Estados Unidos, que em 1970 detinham 37\% da produção mundial de alumínio, em 2004, aparecem com 8\% da produção mundial. O Japão que era responsável por 7,5\% da produção mundial, já em 1989 detinha apenas 0,2\%.

Em sentido inverso, países como Brasil e China aumentaram significativamente suas produções de alumínio, saíram de posições quase que insignificantes em relação à produção mundial para constarem entre os seis maiores produtores mundiais de alumínio no mesmo período.

\begin{tabular}{|c|c|c|c|c|}
\hline \multicolumn{5}{|c|}{$\begin{array}{l}\text { Quadro } 11 \text { - Evolução \% da participação dos países na } \\
\text { produção mundial de alumínio }\end{array}$} \\
\hline País & 1970 & 1989 & 1995 & 2004 \\
\hline Estados Unidos & $37 \%$ & $20 \%$ & $17 \%$ & $8 \%$ \\
\hline Canadá & $10 \%$ & $8,50 \%$ & $11 \%$ & $9 \%$ \\
\hline Japão & $7,50 \%$ & $0,20 \%$ & - & - \\
\hline Austrália & $2 \%$ & $7 \%$ & $7 \%$ & $6 \%$ \\
\hline China & $1 \%$ & $5 \%$ & $9 \%$ & $22 \%$ \\
\hline Brasil & $0,60 \%$ & $5 \%$ & $6 \%$ & $5 \%$ \\
\hline
\end{tabular}

Fonte: Bermann, 1993 e Instituto Observatório Social, 2006.

Elaborado por Alexandre do Nascimento Souza

Ao analisarmos o quadro 12 constatamos relação direta entre sete maiores produtores de alumínio no mundo e os seis maiores produtores de energia hidrelétrica do planeta em 2004. Os seis maiores produtores de energia hidrelétrica constam entre os sete maiores produtores de alumínio.

A exceção é feita à Austrália que é o $4^{\circ}$ maior produtor de alumínio, mas não consta entre os maiores produtores de hidroeletricidade. 


\begin{tabular}{|l|c|c|}
\hline \multicolumn{3}{|l|}{ Quadro 12 - Os 7 maiores produtores } \\
\hline Países & Hidroeletricidade & Alumínio \\
\hline China & $6 \%$ & $22 \%$ \\
\hline Rússia & $9 \%$ & $12 \%$ \\
\hline Canadá & $13 \%$ & $9 \%$ \\
\hline Estados Unidos & $12 \%$ & $8 \%$ \\
\hline Brasil & $12 \%$ & $5 \%$ \\
\hline Austrália & - & $6 \%$ \\
\hline Suécia e Noruega & $11 \%$ & $4 \%$ \\
\hline
\end{tabular}

Fonte: IOS, 2006 e Tolmasquim, 2005.

Elaborado por Alexandre do Nascimento Souza

Nos últimos 10 anos, a indústria do alumínio passou por um ciclo virtuoso, com crescimento de 53\%, impulsionada principalmente pela China, que em 2003 respondeu por 18,8\% da demanda total por alumínio e por $50,7 \%$ do crescimento da demanda global. O crescimento da produção de alumínio primário entre 1996 e 2005 tem se dado a uma expansão média anual de 4,8\%; entre os anos de 2001 e 2005, a produção aumentou a uma taxa média de $7 \%$ ao ano (INSTITUTO OBSERVATÓRIO SOCIAL, 2006).

\subsubsection{A indústria de Alumínio no Brasil: um produto de exportação}

A produção de alumínio no Brasil cresceu ao longo das últimas duas décadas e saltou de 260 mil toneladas em 1980, para 1.460 mil toneladas em 2004, um crescimento de $460 \%$.

Figura 14

Evolução da Produção de Alumínio no Brasil

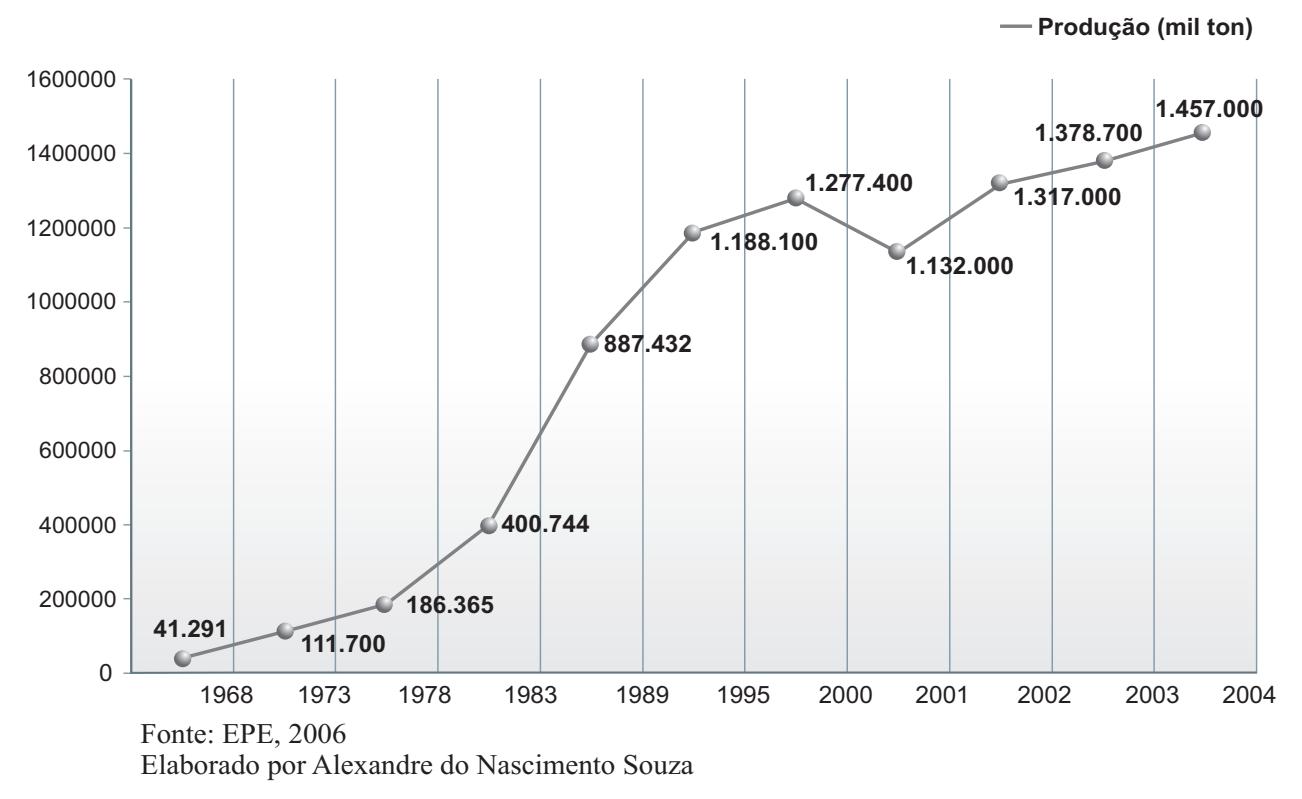


Em 2005, a cadeia de produção do alumínio (bauxita, alumina e alumínio primário) foi responsável por um saldo de $\mathrm{R} \$ 2,3$ bilhões, cerca de $5 \%$ do superávit comercial total do país.

A produção brasileira de alumínio está concentrada em 6 grupos: Albrás, Alcan, Alcoa, Valesul/CRVD, BHP Billiton e CBA; distribuídas em 7 plantas produtivas. As grandes jazidas de bauxita e o potencial de oferta de energia hidrelétrica impulsionaram o estabelecimento das maiores indústrias na região norte do país, que concentra 57\% da produção nacional (EPE, 2005).

À medida que a produção brasileira de alumínio cresce, tem crescido também o percentual de exportação da produção. Em 1983, 44,5\% da produção foi exportada, e seis anos depois, o percentual de alumínio vendido fora do país já era de 61,5\%. Em 2004, 71,3\% da produção brasileira de alumínio foi exportada.

\begin{tabular}{|c|c|c|}
\hline \multicolumn{3}{|c|}{ Quadro 13 - Produção e destino do Alumínio brasileiro } \\
\hline Ano & Produção (ton.) & Part. Exportação (\%) \\
\hline 1968 & 41.291 & 0,8 \\
\hline 1973 & 111.700 & 1 \\
\hline 1978 & 186.365 & 2,1 \\
\hline 1983 & 400.744 & 44,5 \\
\hline 1989 & 887.432 & 61,5 \\
\hline 1995 & 1.188 .100 & 59,2 \\
\hline 2000 & 1.277 .400 & 71,4 \\
\hline 2001 & 1.132 .000 & 64,4 \\
\hline 2002 & 1.317 .000 & 66,9 \\
\hline 2003 & 1.378 .700 & 71,7 \\
\hline 2004 & 1.457 .000 & 71,3 \\
\hline
\end{tabular}

Fonte: Bermann, 2006 e EPE, 2005.

Elaborado por Alexandre do Nascimento Souza

Das tabelas e gráficos apresentados é possível inferir-se uma relação entre a produção do alumínio brasileiro e o processo de estruturação global desta indústria no mundo. O contínuo crescimento da demanda, sobretudo impulsionada pela China, o aumento dos investimentos das indústrias brasileiras em sua capacidade produtiva, além do aumento das exportações indicam que o Brasil passou a ser uma plataforma produtora e exportadora de alumínio, no mesmo período em que países como EUA e Japão diminuíram significativamente suas produções. 
Esse tipo de situação tem sido citada pelos críticos da modernização ecológica, que acusam os países desenvolvidos de promoverem a reforma ambiental ao exportar para os países em desenvolvimento seus processos produtivos com potencial de degradação ambiental.

Eles (críticos da ME) reivindicam que a teoria é aplicável somente em sociedades industrializadas, porque despreza amplamente a questão de uma igual distribuição dos recursos naturais entre os diferentes grupos e Estados-nação. Em consonância com os teóricos 'do Sistema Mundial' e os neomarxistas, estes estudiosos argumentam que uma estratégia de modernização ecológica na parte desenvolvida do mundo só é possível por causa da rede de retirada de recursos e da rede de adição de poluição dos países em desenvolvimento pelos países mais desenvolvidos (MOL, 2001, p.65).

\title{
4.3.3 A indústria do alumínio e a construção de hidrelétricas
}

A energia elétrica é um insumo central à produção do alumínio. Cerca de $35 \%$ do custo de produção é eletricidade. Para se produzir uma tonelada do produto são necessários entre 15.000 e 16.000 KWh por tonelada. Em 2004, o consumo de energia por esta indústria foi de 5,7\% da carga nacional (EPE, 2005).

A forte dependência da eletricidade no processo produtivo,

\begin{abstract}
o realinhamento tarifário com gradual supressão de subsídios cruzados, as mudanças na legislação para incentivar novos incrementos de energia e os riscos de novos apagões como o ocorrido em 2001, têm levado à indústria de energo-intensivo a participar da geração de energia na figura dos autoprodutores, produtores independentes e cogeradores de energia elétrica" (EPE, 2005, p.194).
\end{abstract}

A flexibilização da legislação e a possibilidade de participação de outros setores da economia no incremento do parque de geração hidrelétrica permitiu que entre os anos de 1998 e 2005 entrassem em operação 15 novas usinas hidrelétricas, totalizando a potência de $4220 \mathrm{MW}$, sendo que destes; $56,9 \%$ ou 2400 MW, são classificados como autoprodução transportada ${ }^{74}$.

\footnotetext{
${ }^{74}$ Autoprodução transportada é um termo utilizado pelo setor elétrico e significa que uma empresa produz a energia elétrica longe do seu local de consumo e a coloca no Sistema Interligado Nacional e a retira da rede nacional no local de consumo da eletricidade, pagando apenas as perdas elétricas e o uso do sistema de transmissão.
} 
Esse valor é aproximadamente o dobro da potência instalada em 2003 (1.206 MW) em usinas hidrelétricas concedidas ou autorizadas para a autoprodução. A indústria do alumínio é proprietária de 772 MW, 32\% do take ${ }^{75}$ dos energo-intensivos.

\begin{tabular}{|c|c|c|}
\hline \multicolumn{3}{|c|}{ Quadro 14 - Take das Empresas energo intensivas } \\
\hline Empresa & Take MW & $\%$ \\
\hline CBA & 431 & \\
\hline Alcoa & 258 & \\
\hline Valesul & 83 & \\
\hline Total Ind. Alumínio & 772 & 18.3 \\
\hline Outras Industrias energo-intensivas ** & 1629 & 38.6 \\
\hline Take Consumidores energo-intensivos & 2401 & 56.9 \\
\hline Gerador ou comercializador & 1819 & 43.1 \\
\hline Total da autoprodução transportada & 4220 & \\
\hline $\begin{array}{l}\text { * O Take foi calculado com base na participaçã } \\
\text { empreendimentos hidrelétricos } \\
\text { ** Cimento, Siderurgia, Tecidos e celulose } \\
\text { Fonte: EPE,2005. Pg.196 } \\
\text { Elaborado por Alexandre do Nascimento Sol }\end{array}$ & das indústri & \\
\hline
\end{tabular}

Entre 1994 e 2004, a autoprodução passou de 5,4\% da produção total de eletricidade para 9,5\%, crescimento de $76 \%$; cinco produtores de alumínio, respondem pela produção de $2056 \mathrm{MW}$.

\begin{tabular}{|l|c|c|}
\hline \multicolumn{3}{|c|}{ Quadro 15 - Participação em Empreendimentos de energia* } \\
\hline Produtor & Take MW & \% do total take do setor \\
\hline CBA & 831 & 40.4 \\
\hline Alcoa & 616 & 30.0 \\
\hline Alcan & 287 & 14.0 \\
\hline BHP Billiton & 179 & 8.7 \\
\hline Valesul & 143 & 6.9 \\
\hline Total & $\mathbf{2 0 5 6}$ & $\mathbf{1 0 0 , 0}$ \\
\hline
\end{tabular}

*Empreendimentos em operação e em Construção

Fonte: EPE,2005. Pg.168

Elaborado por Alexandre do Nascimento Souza

Até 2010 estão previstas a entrada em operação de mais 12 usinas hidrelétricas, totalizando novos $3400 \mathrm{MW}$, a indústria do alumínio é responsável por $574 \mathrm{MW} ; 25,7 \%$ do total do take das indústrias energo-intensiva.

\footnotetext{
${ }^{75}$ Take é a potência disponibilizada ao autoprodutor referente a sua participação acionária no empreendimento de geração de energia hidroelétrica.
} 


\begin{tabular}{|l|c|c|}
\hline \multicolumn{3}{|l|}{ Quadro 16 - Expansão prevista Autoprodução hidrelétrica transportada } \\
\hline Empresa & Take MW & \% \\
\hline Alcoa & 315 & \\
\hline BHP Billiton & 179 & \\
\hline CBA & 80 & \\
\hline Total Ind. Alumínio & $\mathbf{5 7 4}$ & 16.9 \\
\hline Gerador ou Comercializador & 1166 & 34.3 \\
\hline Outras Industrias energo-intensivas ** & 1659 & 48.8 \\
\hline Total Expansão Prevista & $\mathbf{3 3 9 9}$ & \\
\hline
\end{tabular}

* O Take foi calculado com base na participação acionária das indústrias nos empreendimentos hidrelétricos

** Cimento, Siderurgia, Tecidos e celulose

Fonte: EPE,2005. Pg.197

Elaborado por Alexandre do Nascimento Souza

A pressão exercida pela expansão do mercado internacional de alumínio tem impulsionado uma participação cada vez maior das indústrias de alumínio no Brasil a ser proprietária de empreendimentos hidrelétricos.

As hidrelétricas construídas por esse setor da indústria nacional, a partir de 1995, quando houve mudanças nas regras do setor elétrico, tiveram queda de $51 \%$ no coeficiente MW gerado por $\mathrm{Km}^{2}$ alagado, um indicador de impacto ambiental, uma vez que avalia quantos $\mathrm{Km}^{2}$ são necessários para a produção de um MW' ${ }^{76}$ (Souza \& Jacobi, 2006).

\subsubsection{Tijuco Alto e o parque hidrelétrico da CBA - Qualidade ambiental inferior às demais UHEs ${ }^{77}$}

A UHE Tijuco Alto terá a quarta pior relação MW gerado por área alagada do conjunto de UHEs da $\mathrm{CBA}, 2,8 \mathrm{MW} / \mathrm{Km}^{2}$.

O pior coeficiente é da UHE Serra do Facão: $1 \mathrm{MW} / \mathrm{Km}^{2}$. O segundo pior coeficiente são das UHEs França e Itupararanga: 2,3 MW gerado por cada $\mathrm{Km}^{2}$ alagado $^{78}$.

\footnotetext{
${ }^{76}$ Um documento do Banco Mundial (1997, p.84) sugere a relação área alagada por MW gerado. O prof. Goldemberg (1988, p. 106) apresenta a relação entre MW gerado por área alagada como indicador. Utilizaremos para efeito desse estudo a proposta do prof. Goldemberg.

${ }^{77}$ Dividimos as UHEs da CBA em dois grupos para diferenciar o marco do setor elétrico no qual foram construídas ou adquiridas.

${ }^{78} \mathrm{~A}$ listagem das hidrelétricas foi feita a partir de informação disponibilizada no site da indústria de alumínio e na publicação da EPE (2005). A ficha técnica de cada uma delas foi pesquisada no SIGEL - Sistema de Informações georreferenciadas do setor elétrico, com último acesso em 13/07/07.
} 
O terceiro pior coeficiente é da UHE Canoas, parceria da CBA com a Duke Energy. Para cada Km² alagado são gerados 2,7MW.

\begin{tabular}{|c|c|c|c|c|c|}
\hline \multicolumn{7}{|c|}{ Quadro 17 - Hidrelétricas: Potência X Área Alagada operação até 1995 } \\
\hline \multicolumn{7}{|c|}{ Iníc da } \\
\hline Ano operação & Hidrelétrica & Potência MW & Área alagada KM & MW/ KM & Proprietários \\
\hline 1974 & Alecrim & 72 & 1,54 & 46.7 & CBA \\
\hline 1986 & Barra & 40.4 & 1,93 & 20,9 & CBA \\
\hline 1958 & França & 29.5 & 12.7 & 2.3 & CBA \\
\hline 1964 & Fumaça & 36.4 & 6.92 & 5.3 & CBA \\
\hline 1974 & Itupararanga & 55 & 24,1 & 2.3 & CBA \\
\hline 1982 & Porto Raso & 28.4 & 1.48 & 19.2 & CBA \\
\hline 1989 & Salto do Iporanga & 36.87 & 2.69 & 13.7 & CBA \\
\hline 1978 & Serraria & 24 & $\mathbf{2 . 1 3}$ & 11.3 & CBA \\
\hline \multicolumn{7}{|c|}{ Média do coeficiente 15.2 MW/KM $\mathbf{~}^{\mathbf{2}}$} \\
\hline
\end{tabular}

\begin{tabular}{|c|c|c|c|c|c|}
\hline \multicolumn{6}{|c|}{ Tabela 18 - Hidrelétricas: Potência X Área Alagada } \\
\hline \multicolumn{6}{|c|}{ Início da operação a partir de $\mathbf{2 0 0 0}$} \\
\hline Ano operação & Hidrelétrica & $\begin{array}{c}\text { Potência } \\
\text { MW }\end{array}$ & $\begin{array}{c}\text { Área alagada } \\
\mathrm{KM}^{2} \\
\end{array}$ & MW/KM ${ }^{2}$ & Proprietários \\
\hline 2005 & Barra Grande & 690 & 92 & 7.5 & Alcoa/CBA e outras \\
\hline 2007 & Campos Novos & 880 & 33,7 & 26.1 & CBA e outras \\
\hline 2000 & Canoas I & 82.5 & 31 & 2.7 & CBA/DUKE \\
\hline 2000 & Canoas II & 72 & 23,61 & 3.1 & CBA/DUKE \\
\hline 2002 & Piraju & 70 & 17,2 & 4.1 & CBA \\
\hline 2002 & Machadinho & 1140 & 72 & 15.8 & CBA/Alcoa/Valesul \\
\hline 2005 & Ourinhos & 44 & 4,33 & 10.2 & CBA \\
\hline 2007 & Serra do Facão & 210 & 208,5 & 1 & Alcoa / CBA / Vcim \\
\hline \multicolumn{6}{|c|}{ Média do coeficiente $8.8 \mathrm{MW} / \mathrm{KM}^{2}$} \\
\hline
\end{tabular}

\subsubsection{CBA e Tijuco Alto - Mais energia, menor custo e independência energética ${ }^{79}$}

A Companhia Brasileira de Alumínio pertence ao grupo Votorantim e tem mais de 50 anos. É a segunda maior produtora de alumínio do Brasil e maior fábrica do mundo na qual todo o processo produtivo está integrado na mesma planta - da extração do minério da bauxita até os produtos de alumínio transformado.

\footnotetext{
${ }^{79}$ As informações a respeito da CBA foram colhidas do EIA/RIMA, das apresentações nas audiências públicas e da revista IstoÉ Dinheiro nº 526, 24/10/2007, na qual trouxe na capa o sucesso da CBA como empresa do ano.
} 
Figura 15 - Fábrica da CBA em Alumínio. Todo processo integrado em uma mesma unidade.

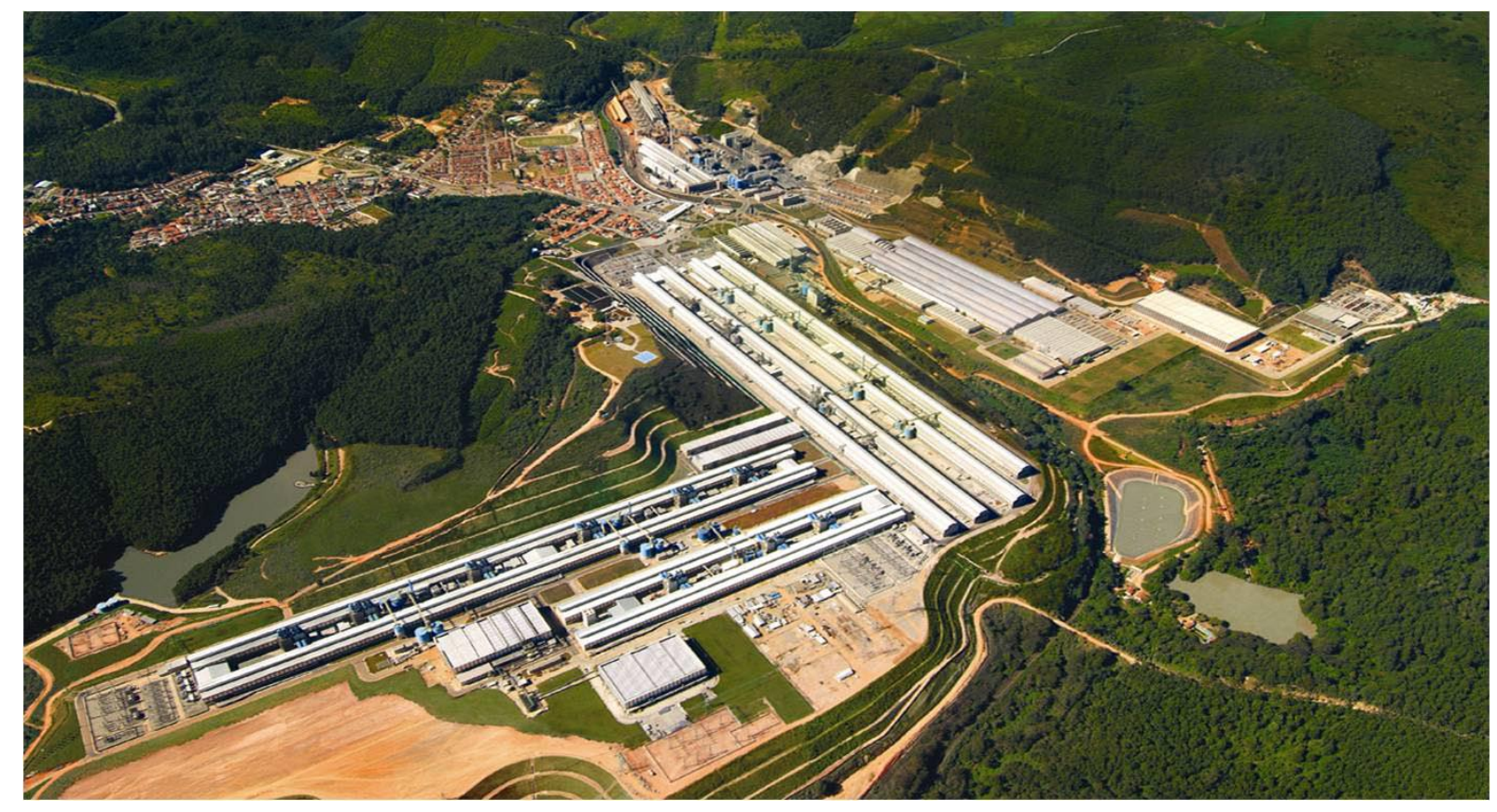

Foto extraída apresentação CNEC sobre Tijuco Alto

ACBA produz vários materiais da linha do alumínio, chapas, filmes de embalagens, cabos, etc. A companhia exporta 50\% de sua produção para os EUA, países da Europa, América Latina e Oriente Médio.

Nos últimos 13 anos, a indústria de alumínio tem tido crescimento médio anual em torno de 10\%.Para sustentar o crescimento de sua produção a companhia tem investido na estratégia de construir hidrelétricas sozinha, como pretende que seja Tijuco Alto, ou em parceria.

No mundo, as indústrias de alumínio têm em média $28 \%$ de auto-suficência energética, a CBA tem $60 \%$. Faz parte do modelo de negócio da indústria produzir no mínimo 50\% da energia que consome. Atualmente produz cerca de 470 mil toneladas de alumínio por ano e após a construção de Tijuco Alto espera aumentar sua produção para 600 mil toneladas.

A indústria faturou RS 2,7 bilhões em 2006 e teve um lucro operacional de R 712 milhões ou $26 \%$. A empresa investiu no seu sistema produtivo $\mathrm{R} \$ 5$ bilhões nos últimos cinco anos. Deste montante, $70 \%$ foi investimento com recursos próprios.

Uma hidrelétrica se paga com 25 anos de operação, depois disso, seus custos são só operacionais 
(Reis, 2001). A estratégia da CBA e das demais empresas energo-intensivas busca resolver dois problemas centrais do processo produtivo:
a) Garantia de suprimento;
b) Preço do insumo.

Depois do apagão de 2001, ter uma hidrelétrica funciona como seguro contra a falta de energia, é certeza de garantia do insumo.

Ao produzir sua própria energia, a CBA retira de seu custo o lucro do produtor de energia e com uma boa estratégia produtiva poderá até ter um custo de produção menor.

A baixa qualidade das hidrelétricas construídas pela CBA e demais indústrias de alumínio após as mudanças no sistema elétrico em 1995 podem ter relação com essa situação.

Estas hidrelétricas no jargão administrativo financeiro estão na conta custo. Diferente do que se a CBA vendesse eletricidade, e produzir energia fosse atividade fim da empresa, no caso das hidrelétricas do alumínio, elas são insumo e não produto.

Qualquer real economizado será ganho de escala no final do processo. Como uma hidrelétrica é um bem de capital intensivo, procedimentos que otimizam o processo economizam milhões de reais.

Outro fator que está na raiz da baixa qualidade dos empreendimentos mais novos é o fato de os locais com melhores potenciais hidrelétricos terem sido os primeiros a serem construídos, sobretudo nas regiões Sul e Sudeste.

Aproveitar o potencial da região norte envolve questões complexas, em alguns casos terras indígenas, o que demanda autorização do Congresso para serem alagadas. Os novos empreendimentos respondem a uma demanda das indústrias em ter maior segurança e menor custo em seu processo produtivo.

Na prática, o que está ocorrendo com a indústria de alumínio no Brasil é que ela tem sido chamada a responder pelo aumento crescente da demanda por alumínio e para isso precisa de mais energia. Se o cenário é de escassez de energia, ela mesma produz. 
A piora dos indicadores de MW gerado por área alagada são indicativos que, ao menos em parte, os conflitos relacionados aos processos de licenciamento ambiental destes empreendimentos não eram meros caprichos ideológicos, uma vez que as novas hidrelétricas, sob os critérios reconhecidos internacionalmente $\left(\mathrm{MW} / \mathrm{Km}^{2}\right)$, têm qualidade inferior do que outras geridas pelo mesmo setor.

Tijuco Alto se encaixa na lógica atual da indústria do alumínio e seu esforço para dotar seu processo produtivo de segurança energética por um lado, e ter ganhos de escala por outro. Mesmo quando comparada aos 8 empreendimentos mais recentes da CBA, a UHE Tijuco Alto, 2,8 MW/ Km² tem qualidade ambiental inferior a seis deles.

\subsection{A HIDRELÉTRICA TIJUCO ALTO - 20 ANOS EM LICENCIAMENTO}

AUHETijuco Alto ${ }^{80}$ é um exemplo dos mais significativos em relação a toda controvérsia na qual está imersa o sistema de licenciamento ambiental no país. O licenciamento da UHE dura 20 anos e a emissão ou não da licença ainda está por ser definida.

O empreendimento já teve a licença negada em 2003, no entanto, o parecer que indeferiu a licença deixou aberta a possibilidade de um novo processo de licenciamento desde quando fosse feito um novo EIA, uma vez que o primeiro, entregue em 1989, sofreu inúmeras complementações.

Em 2004, a CBA iniciou outro processo de licenciamento. A equipe de analistas do IBAMA concedeu parecer favorável à emissão da licença prévia da UHE em 26/2/2008, mas o condicionou à resolução de três situações:

1. As disposições do Decreto ${ }^{\circ}$ 99.556/90, que proíbe a destruição de cavernas naturais e o lago da UHE prevê a submersão de duas cavernas. Em 11 de novembro de 2008, o governo brasileiro publicou decreto que classifica as cavernas em 4 categorias. Em três destas categorias, as cavernas poderão ser submersas.

\footnotetext{
${ }^{80}$ No discurso do setor elétrico, as hidrelétricas são tidas como existentes, mesmo antes de existir. O correto seria dizer aproveitamento hidrelétrico Tijuco Alto, mas o normal é fazer referência ao empreendimento como se ele já existisse. Sendo assim, toda vez que falarmos na UHE Tijuco Alto, estamos nos referindo ao projeto hidrelétrico aproveitamento Tijuco Alto.
} 
2. A validação da ANA quanto ao direito de uso dos recursos hídricos. A outorga concedida pelo DNAEE expirou. Procedimento burocrático de emissão de nova outorga.

\section{Posicionamento da Dilic/IBAMA sobre a realização de novas audiências} públicas, solicitadas no prazo legal. Foi solicitada a realização de audiências públicas, além de nos municípios onde já ocorreram as plenárias, nos municípios de Iguape, Cananéia, São Paulo e Curitiba. Há forte pressão do movimento social local e do Ministério Público para que se realizem ao menos as audiências públicas em Iguape e Cananéia. O IBAMA recebeu parecer jurídico de que do ponto de vista estritamente jurídico, não é necessário realizar mais nenhuma audiência, no entanto, a Diretoria de Licenciamento-Dilic, não se posicionou em definitivo.

Para efeito da presente pesquisa iremos nos referenciar no segundo processo de licenciamento, o qual acompanhamos a realização das audiências públicas, consultamos o processo na sede central do IBAMA em Brasília e entrevistamos diversos atores envolvidos.

\subsubsection{O Primeiro Processo de Licenciamento}

O aproveitamento Tijuco Alto foi outorgado à Companhia Brasileira de Alumínio -CBA, em 1988, um ano depois da indústria requerer ao antigo $\mathrm{DNAEE}^{81}$ autorização para elaboração do projeto básico.

Em 1989, a CBA deu entrada no pedido de licenciamento do empreendimento nas secretarias do meio ambiente dos estados de São Paulo e Paraná.

O EIA apresentado pela companhia passou por inúmeros pedidos de complementação feitos pelas duas secretarias e os órgãos do sistema de licenciamento dos dois estados. Em junho de 1994, a Secretaria do Meio Ambiente do Estado de São Paulo concedeu a licença prévia, meses depois a Secretaria do Meio Ambiente do Paraná acompanhou a SEMA/SPe emitiu a LP.

Em agosto do mesmo ano, o Ministério Público Federal dos dois estados ingressou com Ação Civil

${ }^{81}$ O DNAEE - Departamento Nacional de Energia Elétrica, integrava a estrutura do Ministério das Minas e Energia e suas funções foram transferidas à ANEEL - Agência Nacional de Energia Elétrica. 
Pública na qual requisitou a nulidade das licenças. A alegação foi de que o Rio Ribeira era federal, portanto, deveria ser licenciado pelo IBAMA.

A Justiça concedeu a liminar e antes mesmo do julgamento do mérito, em 1997, a CBA requereu ao IBAMA a licença provisória. O mérito da ação protocolada pelo MPF só foi julgado em 1999 e a justiça cancelou as licenças já concedidas e reconheceu o órgão federal como licenciador.

O IBAMA, por meio do parecer técnico $n^{\circ} 68 / 2003$, indeferiu a licença requerida e orientou a CBA que elaborasse novo EIA.

\subsubsection{O Segundo Processo de Licenciamento}

\begin{tabular}{|l|c|}
\hline \multicolumn{2}{|l|}{ Quadro 19 } \\
\hline $\begin{array}{l}\text { CBA/CNEC Solicita Abertura } \\
\text { Processo }\end{array}$ & $27 / 1 / 2004$ \\
\hline Emissão TR & $30 / 7 / 2004$ \\
\hline Entrega EIA/RIMA & $11 / 10 / 2005$ \\
\hline Aceite do EIA & $27 / 3 / 2007$ \\
\hline Parecer Equipe Técnica Ibama & $26 / 2 / 2008$ \\
\hline
\end{tabular}

O segundo processo de licenciamento foi aberto em 27 de janeiro de 2004, por solicitação da CBA, que indicou a $\mathrm{CNEC}^{82}$ para representar-lhe junto ao IBAMA. O empreendimento foi identificado no órgão federal pelo processo de número 02001.1172-2004-58.

A UHE ${ }^{83}$ em licenciamento, se construída, irá alagar 51,8 km² , terá $142 \mathrm{~m}$ de altura, 44 m de profundidade média e vai gerar 145 MW. O empreendimento está projetado há 335 km de onde deságua o Rio Ribeira, em Iguape; e os municípios que serão diretamente afetados são:

1. Paraná - Cerro Azul, Dr. Ulysses e Adrianópolis;

2. São Paulo - Ribeira e Itapirapuã Paulista.

\footnotetext{
${ }^{82} \mathrm{ACNEC}$ engenharia é uma empresa do grupo Camargo Côrrea que presta serviços de consultoria, no gerenciamento de projetos e em soluções completas de engenharia, que abrangem desde os estudos de viabilidade até o início da operação do empreendimento. http://www.cnec.com.br/htmls/quemsomos.php - acesso 26/11/08.

${ }^{83}$ Todos os dados informados estão referenciados no EIA/RIMA apresentados pela CBA/CNEC e nas audiências públicas.
} 
Caso seja aprovada serão investidos em sua construção R \$ 500 milhões, dos quais cerca de 19,5\% serão gastos com os impactos socioambientais.

\subsubsection{Mudanças no projeto técnico diminuíram impacto ambiental}

Em relação ao projeto técnico anterior, o projeto apresentado em 2004 tem mudanças técnicas em relação ao projeto da UHE apresentado em 1989 que tornam o projeto menos vulnerável do ponto de vista ambiental. Duas delas são paradigmáticas.

A primeira foi a supressão de um túnel de 2200 m que no projeto técnico anterior iria levar a água até a casa de força onde é gerada a energia. No primeiro projeto, a casa de força ficava há $11 \mathrm{~km}$ da barragem. Essa opção praticamente secaria o trecho do Rio entre a barragem e a casa de força. No atual projeto, a casa de força fica ao lado da barragem, não é necessário secar nenhuma parte do Rio.

\section{Figura 16 - Antigo Projeto}

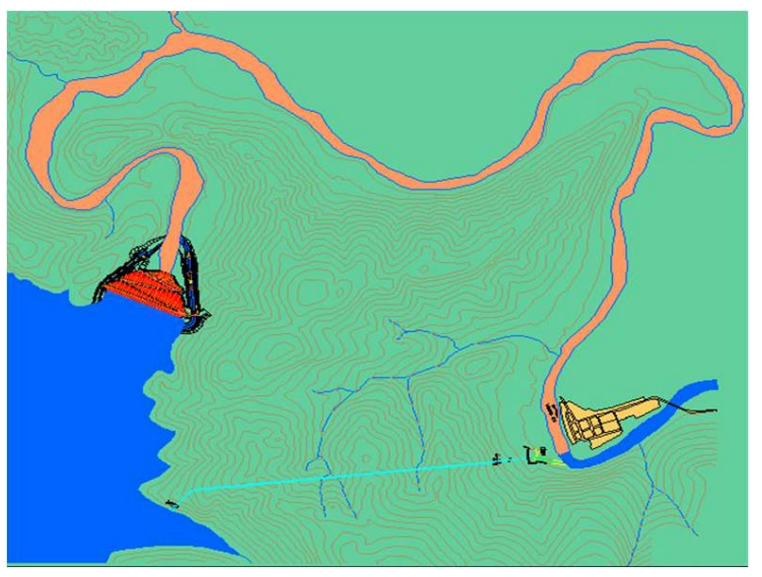

\section{Figura 17 - Novo Projeto}

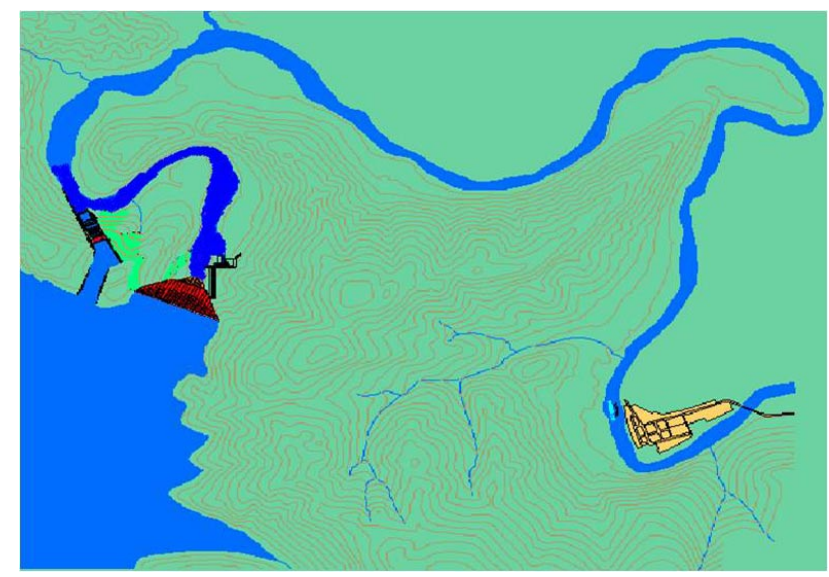

Imagens extraídas de apresentação em Power Point da CNEC sobre o projeto.

A segunda mudança foi a profundidade do ponto de tomada de água ${ }^{84}$. No projeto anterior, a tomada de água seria há $90 \mathrm{~m}$ de profundidade, no atual, a proposta é que a tomada da água que irá fazer rodar as turbinas tenha a profundidade de $18 \mathrm{~m}$.

Devido ao caráter lêntico do reservatório, quanto mais profundo, menor qualidade terá a água. A

\footnotetext{
${ }^{84}$ Local onde estão os dutos por onde passará a água que fará girar as turbinas.
} 
captação em menor profundidade permite que se capte água de melhor qualidade. A opção por menor profundidade de captação garante água de melhor qualidade a jusante da barragem.

No projeto inicial havia um descarregador de fundo ${ }^{85}$ que à época foi considerado uma característica ruim do projeto. O descarregador foi retirado do projeto atual.

Outra mudança foi em relação à transmissão da energia gerada. Anteriormente, eram duas as alternativas: levar energia por uma rede até Curitiba ou até o município de Apiai ${ }^{86}$. No atual projeto, por conta da existência do "linhão ${ }^{87}$ " de Furnas, a energia gerada poderá ser disponibilizada no sistema interligado há 1 km do local de sua geração.

O reservatório terá dois níveis, cota 290 m e cota 300 m. Tijuco Alto vai operar na cota 290 m, dessa forma ficarão disponíveis para momentos de grandes chuvas 10 m que serão utilizados para amortecer cheias e evitar enchentes rio a baixo ${ }^{88}$.

\subsubsection{Promessa de mudança no trato com os ameaçados pela barragem}

Durante o primeiro licenciamento, a maneira como as famílias localizadas nas áreas a serem alagadas foram tratadas gerou descontentamento e os impactos persistem até hoje.

De acordo com Jeronymo (2007), as famílias de não proprietários saíram dos imóveis sem indenização. Muitas famílias foram pressionadas a se desfazer dos seus imóveis que muitas vezes foram comprados a preços irrisórios.

O pesquisador do Instituto de Energia e Eletrotécnica da USP constatou ainda que $41 \%$ das famílias deslocadas compulsoriamente tiveram queda de renda e $35 \%$ tiveram melhora.

\footnotetext{
${ }^{85} \mathrm{O}$ descarregador de fundo é uma comporta que periodicamente pode ser aberta para liberar a água que fíca no fundo do reservatório. O problema é que a montante da barragem existiu mineração e o rejeito da mineração, que ficará submerso quando o lago for formado, poderia contaminar o Rio quando da abertura das comportas.

${ }^{86}$ No primeiro projeto a CBA teria que construir a linha de transmissão, o que acarretaria mais impactos.

${ }^{87}$ Linha de transmissão de alta tensão que integrará o sistema interligado nacional

${ }^{88}$ A CBA apresenta isso como uma espécie de função social da barragem, amortecer possíveis cheias. No entanto, durante o ciclo de audiências houve controvérsia a respeito de quanto a barragem poderia conter do volume de enchentes. Os céticos argumentavam que outras barragens da própria CBA não continham cheias e a CNEC respondia que Tijuco Alto será diferente, pois, já foi projetada com a preocupação de conter enchentes.
} 
Durante as audiências públicas, ocorridas por ocasião do segundo processo de licenciamento, a empresa foi questionada dos fatos ocorridos na década de 90 e se comprometeu a rever injustiças ocorridas no período.

Em diversos momentos do ciclo de audiências públicas, realizadas para discutir o EIA de Tijuco Alto, Ronaldo Crusco, coordenador do EIA em discussão, afirmou que em relação às terras adquiridas anteriormente, os arrendatários, meeiros e parceiros das terras adquiridas pela CBA terão direito ao reassentamento.

Por ocasião do licenciamento anterior, a indústria de alumínio comprou terrenos com bom potencial produtivo, pois alem de estarem à margem do Rio Ribeira, estão parados sem produzir durante todos esses anos.

Figura 18 - Mapa dos terrenos adquiridos pela CBA na década de 90

\section{Malha Fundiária}

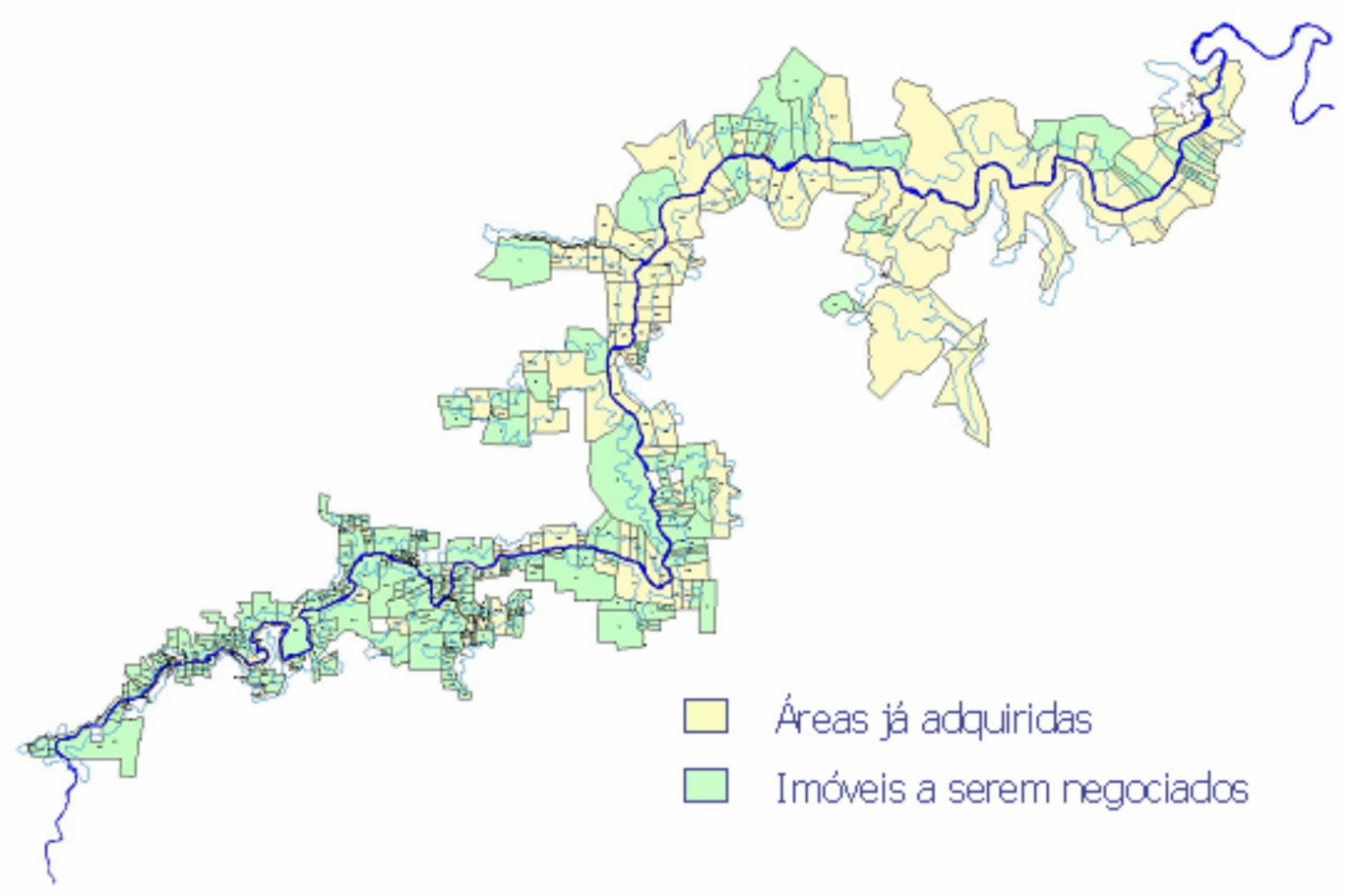

Imagem extraída de apresentação em Power Point da CNEC sobre o projeto.

Essa situação provocou queda na produtividade do município, ocasionando uma série de outras perdas aos municípios da região diretamente afetada (JERONYMO, 2007). A maior parte dos municípi- 
os onde ficará a UHE e municípios vizinhos teve baixo crescimento populacional ou negativo entre 1991 e 2000, enquanto todo o Vale do Ribeira teve crescimento populacional.

\section{Figura 19 - Mapa Populacional do Vale do Ribeira/São Paulo}

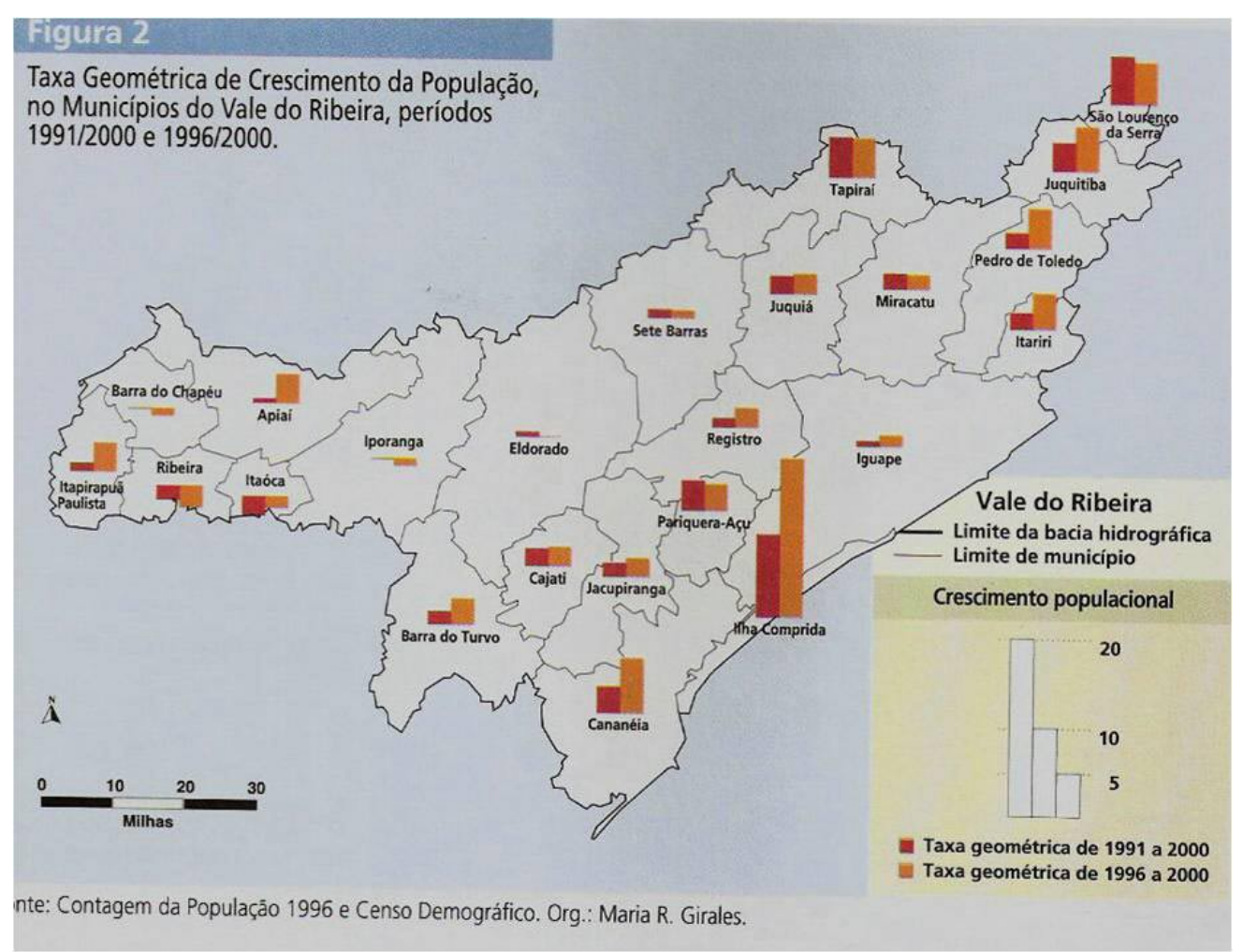

Imagem extraída de Romão Anexo Parte 1, Figura 2, pág. 157.

No projeto apresentado em 2004, a empresa mudou o procedimento e se compromete a indenizar os proprietários e não proprietários, assim como, cada família irá optar pela forma de mitigação que preferir: ressarcimento financeiro ou reassentamento. Cada modalidade tem um conjunto de regras que foram esboçadas durante as audiências públicas.

De acordo com o levantamento apresentado durante as audiências públicas, serão atingidas 578 famílias. Destas, 266 são proprietários de terras e 312 são famílias de não proprietários - arrendatários, parceiros, meeiros, trabalhador fixo, tomador de conta e outros tipos de não proprietários.

Como critério para a definição dos núcleos familiares adotou-se o núcleo familiar autônomo. Se o filho mora nas mesmas terras que os pais, mas já tem uma família e vivem de maneira autônoma, foram consideradas duas famílias. Do total de atingidos, 504 famílias vivem na área rural. 


\subsection{MUDANÇAS SÃO REFLEXO DO DEBATE EM TORNO DO LICENCIAMENTO AMBIENTAL}

As mudanças no projeto técnico da UHE e na proposta de relacionamento com as famílias atingidas refletem o embate que a CBA tem tido nos últimos 20 anos em torno do licenciamento de Tijuco Alto, mas também o acúmulo político e social em torno do licenciamento de hidrelétricas no Brasil.

No segundo projeto, apresentado 15 anos após o primeiro, percebe-se claramente que a CBA/CNEC buscaram responder todas as críticas que o projeto apresentado em 1989 sofreu, mas também buscou responder positivamente em relação a outros problemas que vêm sendo pontuados por estudos científicos e pelo movimento social em relação aos empreendimentos hidrelétricos.

Não por acaso, o RIMA foi feito de forma inovadora, em formato de história em quadrinho no qual “Tio Juco", uma espécie de super herói, alado e com aparência futurista, apresenta o projeto a “Adriana" e "Ribeirinho", uma clara menção aos municípios de Adrianópolis e Ribeira, onde ficará o barramento da hidrelétrica proposta pela $\mathrm{CBA}^{89}$.

Durante o ciclo de audiências foi perceptível o esforço dos consultores da CNEC em utilizar linguagem pouco técnica. Em muitas ocasiões faziam espécies de parêntesis na apresentação do projeto para explicar determinado termo ou noção técnica que utilizavam.

O RIMA em formato de HQ, ilustrado e com linguagem menos técnica, assim como possuidor de uma postura mais didática durante as apresentações e debates a respeito do projeto nas audiências públicas, buscam responder a crítica recorrente nos estudos acadêmicos de que o tecnicismo dos documentos e do debate impossibilitava a compreensão do que estava sendo proposto e debatido por parte das comunidades impactadas pelos empreendimentos.

Durante o ciclo de audiências, algumas vezes, Ronaldo Crusco, engenheiro chefe da equipe de consultores do projeto, fez “mea-culpa” da forma como as famílias residentes na área do lago foram tratadas no primeiro licenciamento.

${ }^{89}$ A barragem ficará em terras do município de Adrianópolis, mas muito próximo a sede do município de Ribeira. 
Os compromissos que a CBA assumiu durante o ciclo de audiências, sobretudo em relação ao tratamento que terão as famílias atingidas, sejam proprietárias ou não - meeiros, posseiros, arrendatários, etc, demonstram mudança do entendimento da empresa em relação aos direitos mobilizados pelas pessoas.

A linha de frente da apresentação e debate do projeto foi feito pela CNEC e seu corpo de consultores, mas todo o ciclo de audiências foi acompanhado por dois funcionários do alto escalão da indústria de alumínio, José Geraldo, diretor de energia e José Rodrigues, diretor de logística, que representaram a empresa toda vez que o debate exigiu um posicionamento da CBA e também na primeira parte da audiência, quando José Rodrigues apresentou a CBA ao plenário.

Ainda que não tenha sido dito de maneira aberta, a proposta da CBA para o trato com as famílias atingidas, se orienta na agenda do MAB. Se a companhia vai cumprir os compromissos, essa será uma outra discussão que só poderá ser feita caso as licenças sejam concedidas. O que se sabe, é que o setor elétrico no Brasil e no mundo tem histórico pouco confiável no cumprimento de compromissos relacionados às populações atingidas, fato apresentado pelo relatório da Comissão Mundial de Barragens e já discutido anteriormente neste texto.

As mudanças no projeto técnico foram significativas e sugerem que houve mudança na estratégia da empresa em relação ao empreendimento. A lógica que parecia vigorar antes era a de maximizar ganhos de processo, pois tanto a cota de captação da água, quanto o próprio túnel que secaria $11 \mathrm{Km}$ do Rio Ribeira garantiam mais energia potencial, ou seja, maior capacidade de produzir energia e durante mais tempo, em caso de longo período sem chuvas.

As duas opções em relação à captação da água, constante no novo projeto, significam ganho do ponto de vista ambiental se considerarmos que não mais ficarão secos $11 \mathrm{Km}$ do rio e a água despejada a jusante terá uma melhor qualidade, pois será captada $70 \mathrm{~m}$ acima do que propunha o primeiro projeto.

Em relação à profundidade da tomada de água, quanto mais profundo for o ponto de captação da água, maior quantidade de água poderá ser captada, sobretudo no período de pouca chuva, quando os reservatórios ficam com menor volume e, portanto, há diminuição da profundidade dos reservatórios. Quanto mais profundo for o ponto de captação, mais água poderá ser captada, até que o reservatório alcance a profundidade de captação. 
A opção de diminuir a profundidade de captação da água no reservatório faz com que em tese se diminua o potencial de geração de energia, uma vez que, em épocas de seca, com a diminuição da profundidade do reservatório, se o ponto de captação tem pouca profundidade, a geração de energia só poderá captar água até a profundidade do ponto de captação, ainda que haja água armazenada abaixo dele. Se o ponto de captação é mais profundo se capta água durante mais tempo, mesmo na época de estiagem.

No atual projeto, as mudanças significativas, sugerem que a empresa optou por garantir a aprovação do empreendimento, ainda que isso signifique mais custos na mitigação dos impactos sociais e menor produção de energia em potencial.

A proposta de mitigação dos impactos sociais do atual projeto em licenciamento contempla inclusive, a reparação financeira às famílias que saíram das terras adquiridas pela CBA nos anos 90 e que não foram indenizadas.

As mudanças evidenciam duas coisas:

I. A mentalidade do setor empreendedor nos anos 90 , onde o projeto tinha a primazia do processo, ainda que isso significasse impactar de maneira irreversível o meio ambiente como secar o rio por $11 \mathrm{Km}$, ou submeter a população do Vale do Ribeira ao risco de se contaminar com metais pesados - descarregador de fundo e ponto de captação mais profundo. No atual projeto, a CBA optou por um empreendimento potencialmente menos produtivo, mas com viabilidade socioambiental maior do que o anterior.

II. As vicissitudes do processo de licenciamento ambiental, pois, a melhoria do projeto tanto no aspecto social, quanto, no aspecto ambiental, não ocorreriam sem o processo de licenciamento ambiental.

O processo de licenciamento de Tijuco alto tem algumas peculiaridades devido ao fato de estar próximo a São Paulo, e da região ser de interesse de grupos ambientalistas e a forte mobilização das populações quilombolas. 
Mas ainda assim, está claro que sem a efetividade do instrumento do licenciamento, teria faltado à sociedade condições efetivas de se contrapor à instalação do empreendimento que por tudo que já foi dito aqui, está claro que tinha um perfil socioambiental ruim se o comparamos com o empreendimento proposto no processo de licenciamento iniciado em 2004.

As mudanças ocorridas no projeto da UHE Tijuco Alto e que o tornam melhor em relação ao primeiro guardam sintonia com as conclusões do estudo do Banco Mundial que ao analisar o processo de licenciamento de quatro empreendimentos concluiu que o instrumento contribuiu definitivamente com a melhoria da qualidade ambiental dos empreendimentos (BANCO MUNDIAL, 2008, p.75).

Em que pese as mudanças ocorridas no projeto, a posição de parte significativa dos atores sociais no Vale do Ribeira continuou contrária. O acompanhamento das audiências públicas evidenciou um clima de confronto em torno do empreendimento.

No próximo capítulo iremos apresentar uma síntese etnográfica do ciclo de audiências. 



\section{As Audiências Públicas Síntese Etnográfica}

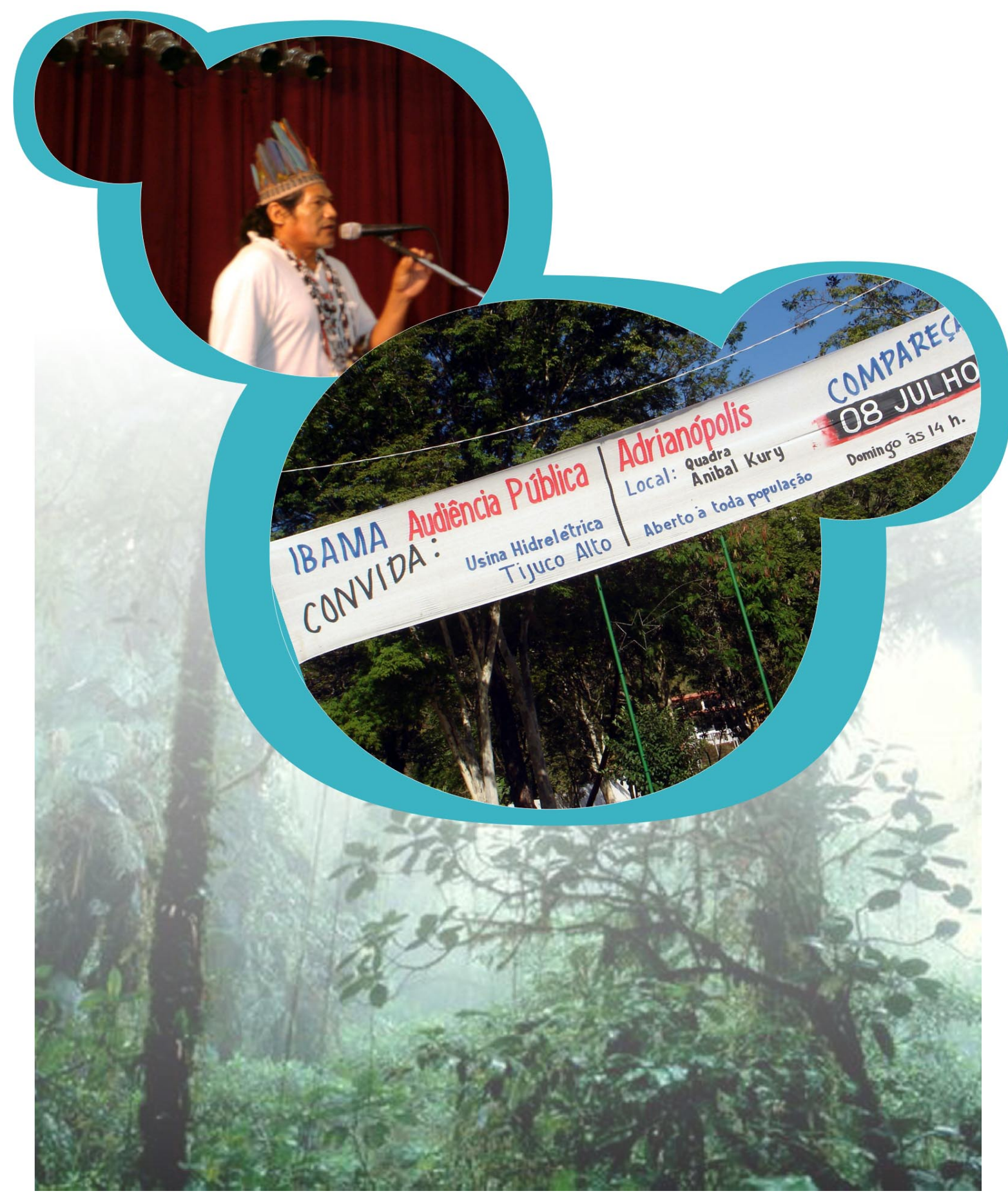




\section{As Audiências Públicas - Síntese Etnográfica}

\subsection{SÍNTESE ETNOGRÁFICA}

As Audiências Públicas do processo de licenciamento da UHE Tijuco Alto ocorreram entre os dias 6 e 10 de julho de 2007 nos municípios de Cerro Azul-PR, Ribeira-SP, Adrianópolis-SP, Eldorado-SP e Registro-SP, respectivamente.

O ciclo das audiências expôs a dinâmica do licenciamento que se arrasta há 20 anos.

Previstas pelo arcabouço legal do processo de licenciamento ambiental, as cinco plenárias realizadas tiveram o mesmo formato e estrutura de acontecimentos semelhantes, com poucos aspectos particulares entre elas.

No geral, tratou-se de eventos que pouco dialogaram com os munícipes que não estavam envolvidos com a discussão do licenciamento e que foram às discussões.

Um dos traços mais característicos das audiências foi o fato de que depois de servido o lanche, no intervalo entre a primeira e segunda parte dos debates, o plenário começava a esvaziar. As plenárias terminaram sempre com público inferior a $10 \%$ do total de pessoas presentes no início. Em Cerro Azul, Eldorado e Registro, as audiências de maior público e onde o embate foi mais explícito, o público ao final não era maior do que 20 pessoas.

Do nosso ponto de vista, este é um claro sinal dos limites do processo de licenciamento tal como é feito atualmente. Como já apontamos no capítulo 3, os diversos interesses que gravitam em torno do empreendimento se encontram para debater o projeto somente no momento das audiências. O debate tardio faz com que prevaleça o espírito de confronto ao de construção coletiva. 
Figura 20 - Audiências Públicas no início dos debates e algumas horas depois. Invariavelmente os salões foram ficando vazios

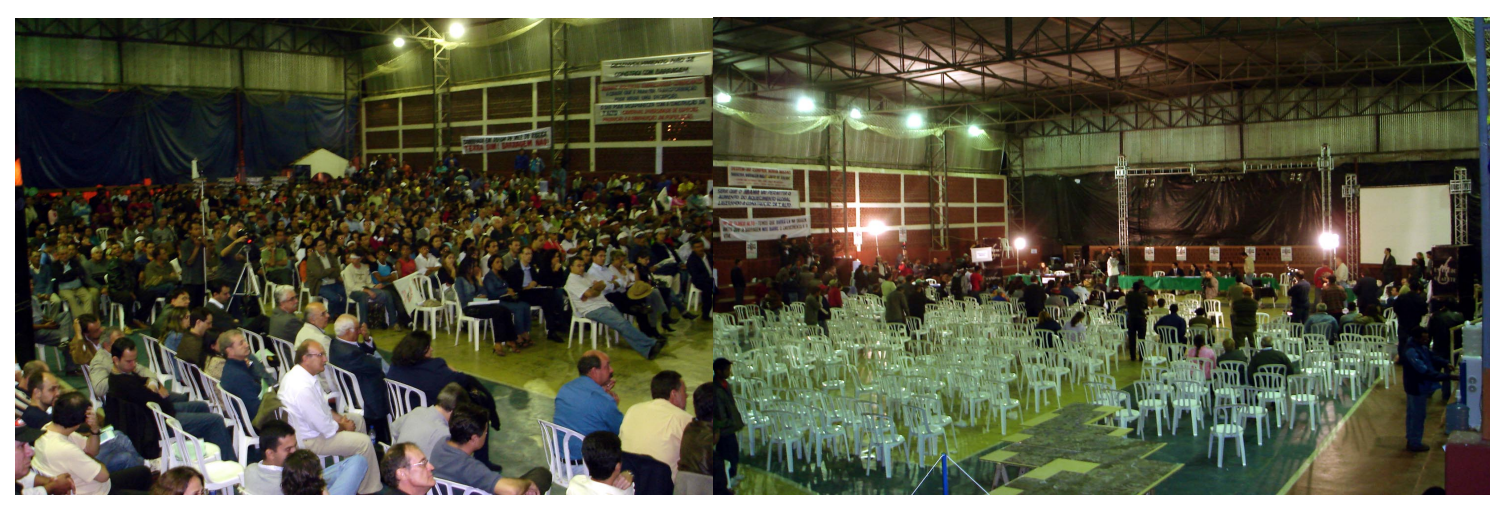

Fotos: Cerro Azul 06/07/2007

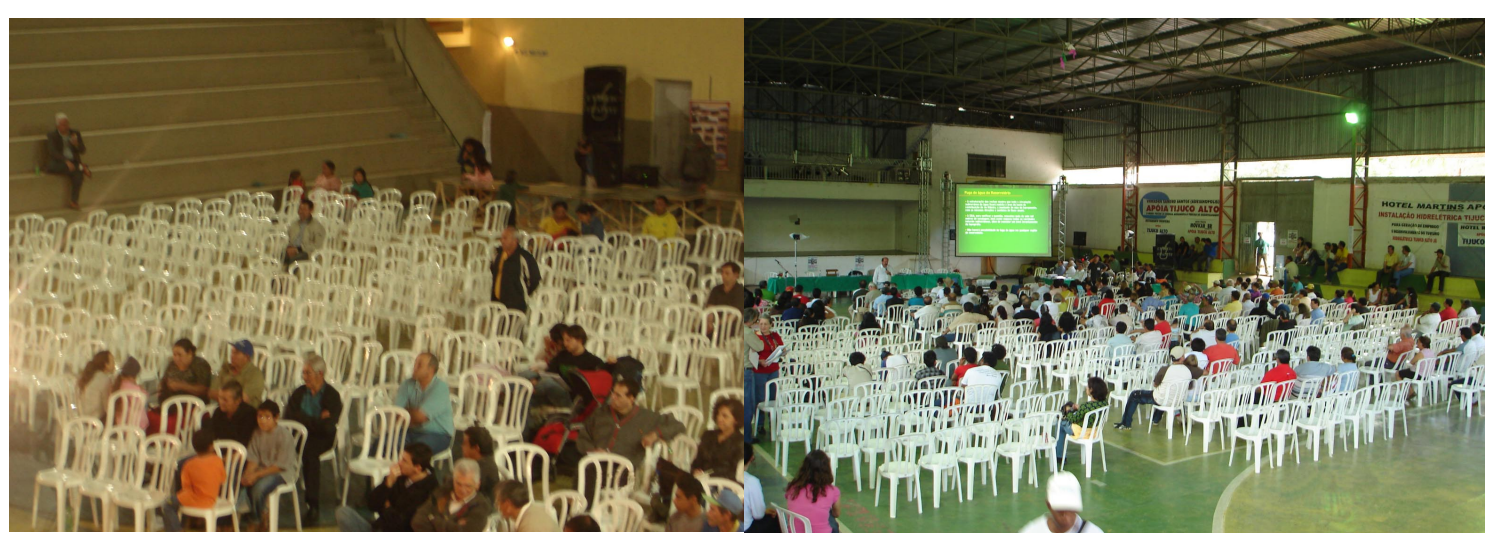

Foto: Ribeira 7/07/2007

\section{Foto: Adrianópolis 08/07/07}

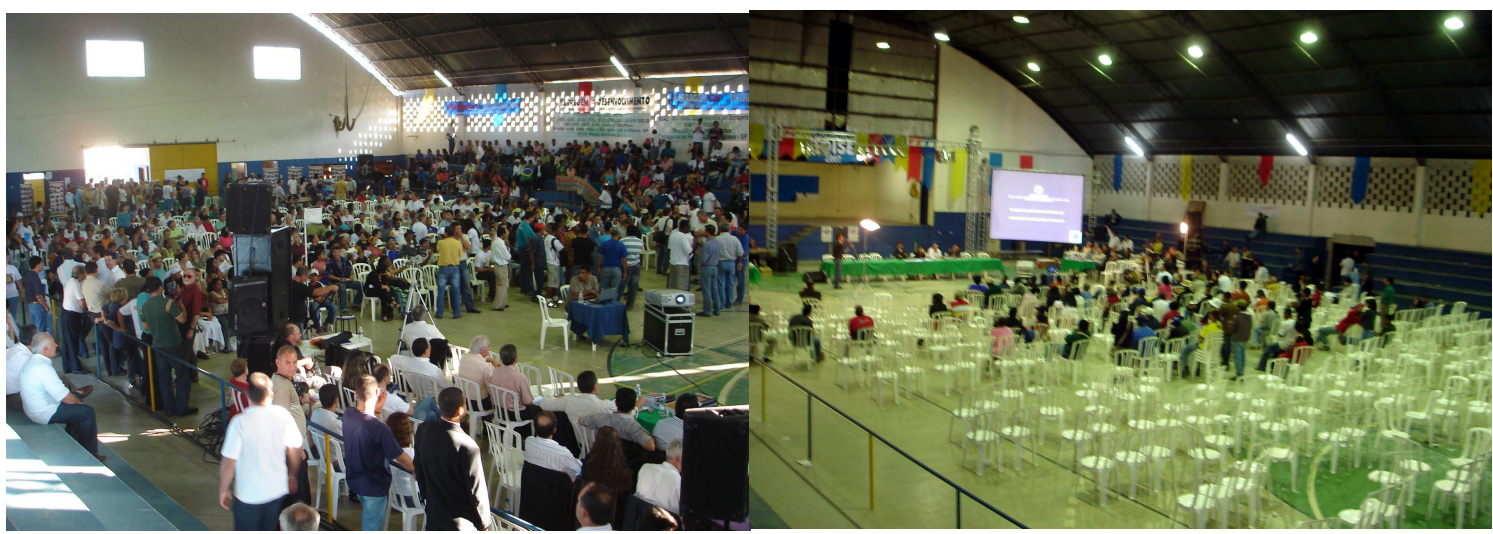

Fotos: Eldorado 9/07/2007

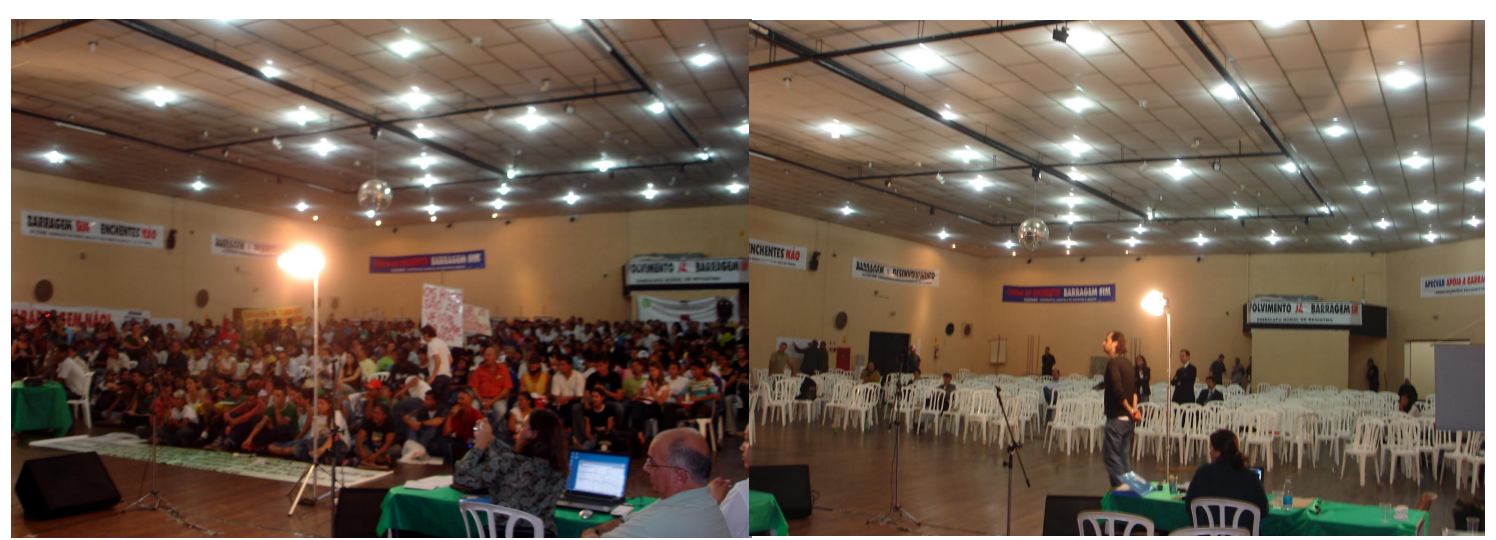

Fotos: Registro 10/07/2007 
O início do esvaziamento das audiências logo após a primeira hora, na qual cerca de $50 \%$ das falas foram favoráveis ao empreendimento (Tabela 1), e considerando-se que esse percentual mudou completamente a partir da segunda hora das plenárias, cria um fato pouco representativo do conjunto da discussão: a maioria das pessoas que foi às audiências e saiu antes do término das discussões, podem ter sido convencidas que o projeto da UHE tem viabilidade ambiental e é um bom negócio para o Vale do Ribeira ${ }^{90}$.

Isso ocorreu não em função da formação de um consenso, mas porque na primeira hora dos debates, quando havia maior parte da audiência, $47 \%$ das falas foram favoráveis ao empreendimento, e apenas $11,7 \%$ foram desfavoráveis. No conjunto das intervenções ocorridas durante o ciclo de audiências, $17,9 \%$ das falas foram favoráveis ao empreendimento; contra $58,9 \%$ desfavoráveis.

Quando se iniciava a parte do debate destinada às falas dos representantes dos interesses locais, mais críticos ao empreendimento, parte significativa do público inicial já tinha ido embora, depois que o lanche era servido.

\footnotetext{
${ }^{90}$ Não estou discutindo o mérito do projeto.

${ }^{91}$ Todas as tabelas apresentadas a partir deste capítulo foram elaboradas pelo autor a partir da análise de todas as intervenções ocorridas nas cinco audiências públicas que ocorreram entre os dias 06 e 10 de julho de 2007. A análise foi feita a partir da decupagem da gravação de todas as plenárias. Para o cruzamento das informações e geração dos dados estatísticos e numéricos foi utilizado o softerware SPSS 14.

Para cada uma das intervenções foram extraídas as seguintes informações: qual audiência pública, nome do participante, que tipo de ator social, município de origem, hora da intervenção, posição em relação a UHE, característica da fala (pergunta, reflexão ou posicionamento), utilização ou não de documentos, sentidos construído pela intervenção e pelas respostas da CBA/CNEC, IBAMA e MME. Para cada intervenção foram registrados até 10 sentidos construídos. As respostas da consultoria e empreendedor, assim como dos órgãos de Estado (MME e IBAMA) também tiveram até 10 sentidos registrados.

Os sentidos construídos das intervenções foram sistematizados a partir do conceito de dialogismo (BAKHTIN, 1986). De acordo com este conceito, os discursos que configuram uma determinada realidade dialogam entre si, com os discursos que os antecederam, e com os discursos futuros, uma vez que o "outro" para o qual se destina o discurso está sempre presente na de elaboração discursiva, agindo coercitivamente, influenciando decisivamente em sua forma e seus sentidos. O sentido se constrói na relação interna (em relação ao próprio texto) e externa (em relação a sua recepção), formando um todo significante que inclui inclusive o contexto no qual é proferido.

Nesse sentido classificamos em um mesmo sentido construído falas que não eram idênticas, mas que carregavam em seu cerne a mesma lógica em relação às questões em debate.
} 


\begin{tabular}{|l|c|c|c|}
\hline \multicolumn{4}{|c|}{ Tabela $1^{91}$ - Relação entre hora da intervenção e posição em relação à UHE } \\
\hline HORA & & POSIÇÃO & NẼ̃ SE \\
& FAVORÁVEL & 4 & 14 \\
\hline $1^{\mathrm{a}}$ & 16 & 3 & 1 \\
\hline $2^{\mathrm{a}}$ & 0 & 17 & 9 \\
\hline $3^{\mathrm{a}}$ & 4 & 20 & 5 \\
\hline $4^{\mathrm{a}}$ & 1 & 16 & 8 \\
\hline $5^{\mathrm{a}}$ & 3 & 16 & 2 \\
\hline $6^{\mathrm{a}}$ & 4 & 10 & 0 \\
\hline $7^{\mathrm{a}}$ & 1 & 16 & 1 \\
\hline $8^{\mathrm{a}}$ & 2 & 102 & 40 \\
\hline TOTAL & 31 & & \\
\hline
\end{tabular}

As plenárias foram divididas em dois momentos:

1) No primeiro as autoridades públicas local, estadual ou federal, o IBAMA, o empreendedor, lideranças sociais e representantes de órgãos públicos que compuseram a mesa de abertura da plenária, fizeram uma rápida sessão de saudação ao evento ${ }^{92}$. Logo depois, era feita a leitura do regulamento da audiência e o órgão licenciador explicava a legislação sobre licenciamento e o histórico do processo da UHE Tijuco Alto. O empreendedor tinha 60 minutos para apresentar o empreendimento, os principais resultados do diagnóstico socioambiental, os principais programas de reparação e ou mitigação dos impactos negativos e finalmente concluía afirmando a viabilidade ambiental da UHE tal como proposta no estudo - arranjo técnico, localização e execução dos programas compensatórios e mitigatórios.

2) O segundo momento era aberto ao plenário que se manifestava através do microfone ou por perguntas escritas. As perguntas buscavam debater com o empreendedor e IBAMA, às vezes MME as características do empreendimento e dos programas destinados a compensar e mitigar os impactos.

\footnotetext{
${ }^{92} \mathrm{~A}$ composição da mesa é uma prerrogativa de quem conduz a plenária, não há uma regra pré-definida a não ser a previsão de que as autoridades que se fizerem presentes deverão compor a mesa de abertura. No ciclo de audiências, o representante do MOAB foi chamado a compor a mesa na plenária do município de Eldorado. Em Cerro Azul, Adrianópolis e Ribeira não houve convite para o movimento social se pronunciar no início da plenária. A representante do MME que falou na abertura dos trabalhos em Eldorado e Registro, nas demais não se manifestou na abertura.
} 
As audiências foram conduzidas (presidência e secretaria) pelo IBAMA. Nos municípios de Cerro Azul e Ribeira o Sr. Rideci Farias as presidiu com um estilo mais atento às formalidades. Nas outras três o Sr. Walter Muchagata o substituiu com um estilo de condução político e mais pragmático. Houve duas mudanças importantes entre a condução de um e outro.

Nas duas primeiras audiências, o sr Farias informava que quem não estivesse no plenário na hora que fosse chamado ao microfone não teria sua pergunta apresentada ao plenário ainda que a tivesse escrito. Nas plenárias de Adrianópolis, Eldorado e Registro, o sr Muchagata leu as perguntas elaboradas por escrito mesmo que seu autor não estivesse no plenário na hora em que fosse chamado ao microfone ${ }^{93}$.

A outra mudança de condução foi que nas três últimas audiências o empreendedor emendou o momento da saudação com a apresentação do empreendimento, tornando o processo mais célere. A fala do IBAMA, feita pelo sr Muchagata, também juntou os dois momentos: saudação à plenária e apresentação da legislação e histórico do licenciamento da UHE Tijuco Alto.

A hidrelétrica proposta fica entre os municípios de Ribeira e Adrianópolis, mas, no entanto, as audiências realizadas nos dois municípios que têm suas sedes separadas por uma ponte com pouco mais de 100 metros, foram frias, se comparadas a plenária de Cerro Azul, a primeira, e as duas últimas realizadas no Médio Vale do Ribeira, já próximo a São Paulo, nas cidades de Eldorado e Registro.

Foram as plenárias com menor tempo de duração, menor número de intervenções e na qual o público local pareceu ser maior do que o público que itinerou durante o ciclo de debates ${ }^{94}$. Os grupos sociais organizados não investiram força política nas discussões ocorridas nos dois municípios. Embora tenham participado também das audiências em Ribeira e Adrianópolis, o fizeram com grupo de militantes reduzidos.

\footnotetext{
${ }^{93}$ Quando entrevistado, após as audiências, no dia 25/03/08, no edifício sede do IBAMA, em Brasília, o sr Muchagata que exercia o cargo de diretor de licenciamento ambiental interino afirmou que as diferenças de condução são normais e que não há um padrão definido de como devem ser conduzidas as audiências, desde que se preservem os princípios de participação democrática a que buscam atender as audiências públicas.

${ }^{94}$ Durante o ciclo de audiências houve um público que as acompanhou - pesquisadores, servidores do MPF técnicos durante as cinco audiências e procuradores nas duas últimas e grupos sociais organizados - MOAB, Coletivo de Educadores do Lagamar, ISA, SOS Mata Atlântica, CEDEA e simpatizantes do movimento social contrário a construção da UHE, muitos deles envolvidos com os debates que ocorreram por ocasião do primeiro processo de licenciamento de Tijuco Alto iniciado no final da década de 80.
} 
A maioria iminente dos grupos sociais que participaram do ciclo de debates tem sua atuação no Médio Ribeira e ou no Baixo Ribeira, já próximo à foz do Rio, a jusante de onde se pretende construir Tijuco Alto. Talvez por isso, as audiências em Eldorado e Registro tenham sido onde o debate foi mais acalorado e contou com a participação de muito mais pessoas e de maior número de militantes dos grupos organizados.

\begin{tabular}{|l|c|}
\hline \multicolumn{2}{|c|}{$\begin{array}{c}\text { Tabela } \text { - Percentual de participação dos atores sociais } \\
\text { sobre conjunto das intervenções* (\%) }\end{array}$} \\
\hline Entidades Mov. Social & 34,1 \\
\hline Coletivo Educador / Coletivo Jovem Caiçara & 14,4 \\
\hline MOAB & 14,4 \\
\hline MST & 4 \\
\hline Sindisaúde & 0,6 \\
\hline Asstraf & 0,6 \\
\hline Cidadãos & 19,1 \\
\hline Munícipes & 18,5 \\
\hline Indígena & 0,6 \\
\hline Políticos & 15 \\
\hline Vereadores & 5,8 \\
\hline Prefeitos & 5,2 \\
\hline Deputados & 4 \\
\hline ONGs Socioambientalistas & 9,2 \\
\hline CEDEA & 2,9 \\
\hline ISA & 2,9 \\
\hline SOS & 2,3 \\
\hline IDESC & 0,6 \\
\hline Outras ONGs & 0,6 \\
\hline Órgãos de Estado & 7,5 \\
\hline Ministério Público & 3,5 \\
\hline IBAMA & 2,3 \\
\hline MME & 1,7 \\
\hline Empreendedor & 5,2 \\
\hline CBA/CNEC & 5,2 \\
\hline Empresários & 3,5 \\
\hline ABAVAR & 1,7 \\
\hline Produtor Rural & 1,1 \\
\hline Empresário de Turismo & 0,6 \\
\hline Outros & 6,4 \\
\hline Espcialista & 0,6 \\
\hline Unicamp & 5,2 \\
\hline Pergunta escrita não identificada \\
\hline
\end{tabular}

* Os percentuais de IBAMA, MME e CBA/CNEC são correpondentes a intervenções no momento de abertura das audiências, antes da apresentação do EIA e do início dos debates 
Do conjunto de instituições sociais, políticas e econômicas que tiveram uma ou mais pessoas pertencentes a seus quadros e que participaram das audiências, apenas a Asstraf tem sede em um dos municípios que estão na área diretamente afetada, pois fica em Cerro Azul.

As demais instituições, sobretudo aquelas que tiveram maior participação são do médio e baixo Ribeira. Um dado importante que a tabela 2 nos revela é que mais de $70 \%$ das intervenções foram feitas por moradores do Vale do Ribeira.

No Município de Cerro Azul, que fica a montante do barramento proposto pela CBA, no Alto Ribeira, houve maior participação dos grupos sociais organizados, em relação às plenárias de Ribeira e Adrianópolis. O MOAB, mas também o ISA e o corpo técnico do MPF tinham mais pessoas do que nas duas audiências realizadas nos municípios onde é proposta a hidrelétrica.

Essa característica observada ao término do quinto dia de debates merece ser destacada porque desnuda o processo de licenciamento de Tijuco Alto e ajuda a pontuar e caracterizar os embates que ocorrem em torno dos processos de licenciamento ambiental no país.

Nas audiências de Eldorado e Registro, todos os grupos que têm atividades políticas e ou econômicas desenvolvidas em torno dos municípios jogaram peso político nas plenárias.

Houve ainda, principalmente na audiência de Eldorado, uma série de pessoas da região, mas que moram fora e também pessoas de São Paulo, pesquisadores acadêmicos ${ }^{95}$ e principalmente gente que faz parte da rede de apoio aos movimentos sociais do Vale do Ribeira e que foram mais uma vez se manifestar e hipotecar apoio ao movimento contrário a Tijuco Alto.

\footnotetext{
${ }^{95}$ Havia na plenária de Eldorado muitos acadêmicos que nos últimos 20 anos desenvolveram ou que ainda desenvolvem alguma atividade de pesquisa no Vale do Ribeira, sem conexão direta com a discussão da hidrelétrica, mas solidário ao movimento contrário a UHE. Havia um outro grupo de pessoas que esteve bastante atuante durante o primeiro licenciamento, mas que hoje não atua diretamente no movimento social, muitos moram fora do Vale do Ribeira, mas foram à plenária de Eldorado que teve casa cheia.
} 


\begin{tabular}{|c|c|c|c|c|c|c|}
\hline Município & $\begin{array}{l}\text { Audiência } \\
\text { Cerro Azul }\end{array}$ & $\begin{array}{c}\text { Audiência } \\
\text { Ribeira }\end{array}$ & $\begin{array}{c}\text { Audiência } \\
\text { Adrianópolis } \\
\end{array}$ & $\begin{array}{l}\text { Audiência } \\
\text { Eldorado }\end{array}$ & $\begin{array}{l}\text { Audiência } \\
\text { Registro }\end{array}$ & $\begin{array}{l}\text { Total Por } \\
\text { Municipio }\end{array}$ \\
\hline Adrianópolis & & & 8 & & & 8 \\
\hline Apiaí & & 2 & 3 & & 2 & 7 \\
\hline Bocaiúva do Sul & 1 & & & & & 1 \\
\hline Brasília & 1 & 2 & 2 & 2 & 2 & 9 \\
\hline Campinas & & & & & 1 & 1 \\
\hline Cananéia & 4 & 5 & 4 & 4 & 9 & 26 \\
\hline Capão Bonito & & 1 & & & & 1 \\
\hline Cerro Azul & 15 & 1 & & 2 & & 18 \\
\hline Curitiba & 2 & & 4 & 1 & 2 & 9 \\
\hline Dr. Ulysses & 1 & & & & & 1 \\
\hline Eldorado & 8 & 2 & & 18 & 4 & 32 \\
\hline Ilha Comprida & & & & 1 & & 1 \\
\hline Itapeúna & & & & 1 & & 1 \\
\hline Juquiá & 1 & & & & & 1 \\
\hline $\begin{array}{l}\text { Pergunta Escrita - } \\
\text { Municipio não identificado }\end{array}$ & & 3 & 2 & 4 & & 9 \\
\hline Porto Novo & & & 1 & & & 1 \\
\hline Registro & & 1 & & 4 & 7 & 12 \\
\hline Ribeira & & 10 & & & & 10 \\
\hline Santos & & & & 2 & 2 & 4 \\
\hline São Paulo & 4 & 3 & 3 & 6 & 5 & 21 \\
\hline Total por Audiência & 37 & 30 & 27 & 45 & 34 & 173 \\
\hline
\end{tabular}

De acordo com a Tabela 3, não houve nenhuma intervenção no ciclo de audiências de nenhum cidadão ou político do município de Itapirapuã Paulista. Nos demais municípios que teriam parte de seu território submerso, apenas Cerro Azul teve cidadãos que intervieram em outras audiências. As intervenções feitas por cidadãos dos municípios de Ribeira e Adrianópolis concentraram-se nas audiências realizadas nos dois municípios.

A observação do ciclo de discussões sobre o aproveitamento hidrelétrico de Tijuco Alto nos mostrou que o debate girou em torno dos grupos organizados do Estado de São Pauloe com atuação política e econômica fora da área de influência direta-AID, consequentemente fora da área diretamente afetada - ADA ${ }^{96}$.

\footnotetext{
${ }^{96} \mathrm{~A}$ área diretamente afetada foi definida pelo Estudo de Impacto Ambiental como sendo a área do reservatório e mais uma faixa de 100 metros ao redor do mesmo.

A área de influência direta foi definida como a área sujeita aos impactos diretos da implantação e operação do empreendimento, levando-se em conta as características sociais, econômicas, físicas e biológicas dos sistemas estudados e das particularidades da hidrelétrica. Compreende os municípios de Ribeira e Itapirapuã Paulista no Estado de São Paulo e Adrianópolis e Cerro Azul no Estado do Paraná.
} 


\section{Figura 21- Área de Influência Direta (AID) e Área Diretamente Afetada}

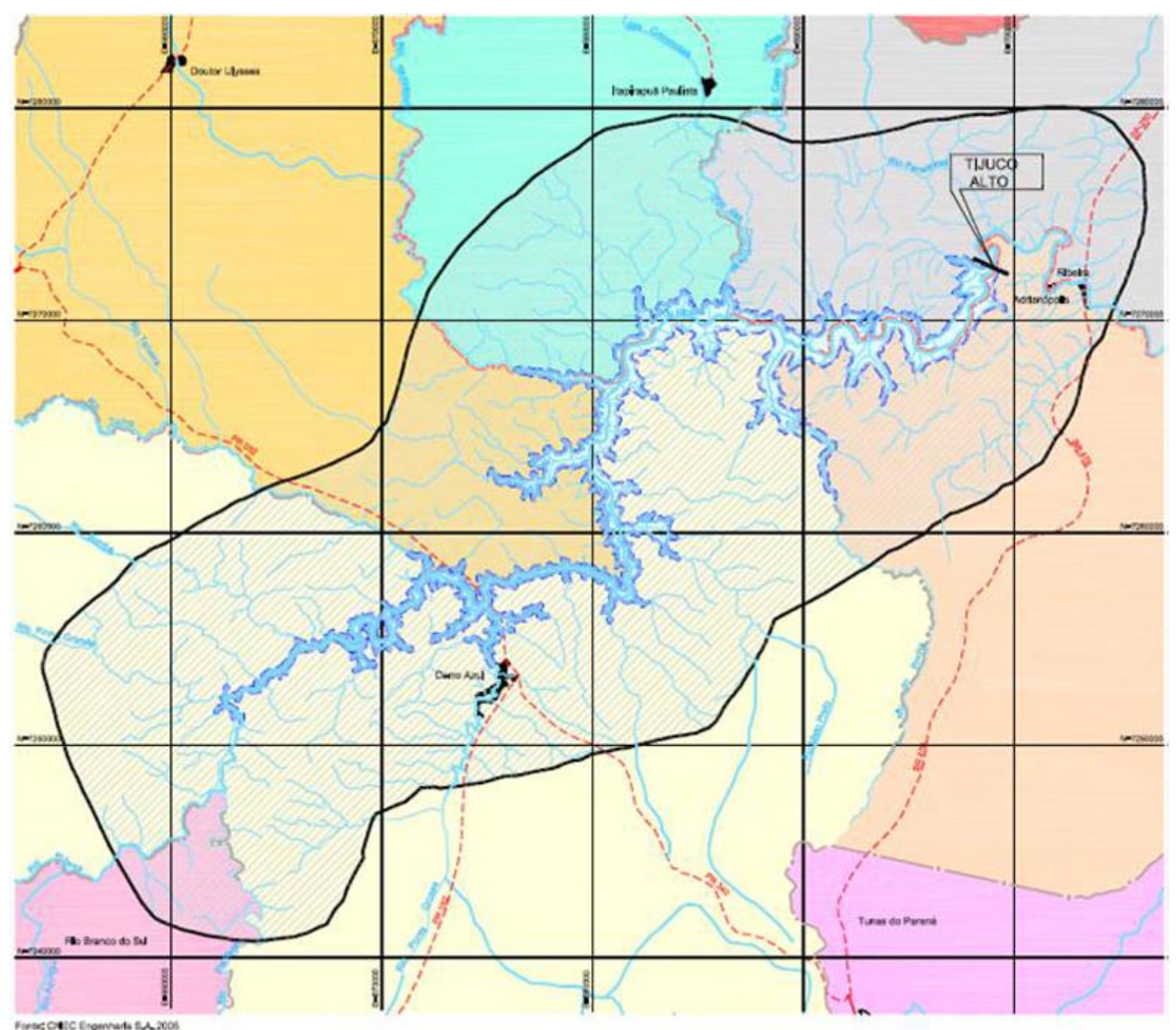

Imagem extraída de apresentação em Power Point da CNEC sobre o projeto Tijuco Alto.

Não se trata de negar a legitimidade dos grupos sociais que participaram do ciclo de audiências: primeiro porque a utilização racional dos recursos ambientais e a viabilidade socioambiental dos empreendimentos é de interesse de todos os brasileiros ${ }^{97}$ e segundo porque a região do Médio Ribeira, onde estão localizados os municípios de Eldorado e Registro faz parte da área de abrangência regional - $\mathrm{AAR}^{98}$ definida pelo estudo. Portanto, o próprio EIA considerou a região de Eldorado e Registro como parte interessada na discussão.

\footnotetext{
${ }^{97}$ Os instrumentos de Avaliação Ambiental, assim como, o próprio licenciamento ambiental foram instituídos exatamente para que os empreendimentos não pudessem assumir a primazia frente os interesses coletivos da sociedade em relação ao ambiente como estabelece a Constituição Federal em seu Art. 225 - "Todos têm direito ao meio ambiente ecologicamente equilibrado, bem de uso comum do povo e essencial à sadia qualidade de vida, impondo-se ao Poder Público e à coletividade o dever de defendê-lo e preservá-lo para as presentes e futuras gerações".

${ }^{98}$ A área de abrangência regional - AAR foi delimitada pelo EIA tendo em vista o potencial hidrelétrico dos outros três empreendimentos (Itaóca, Batatal e Funil) previstos para o curso do Rio Ribeira e que se viabilizam tecnicamente com a construção da UHE tijuco Alto. A AAR compreende a bacia do Rio Ribeira até o município de Registro, área que será impactada caso as demais UHE's sejam construídas. O EIA concluiu que elas não são ambientalmente viáveis.
} 


\section{Figura 22 - Área de Abrangência Regional - AAR}

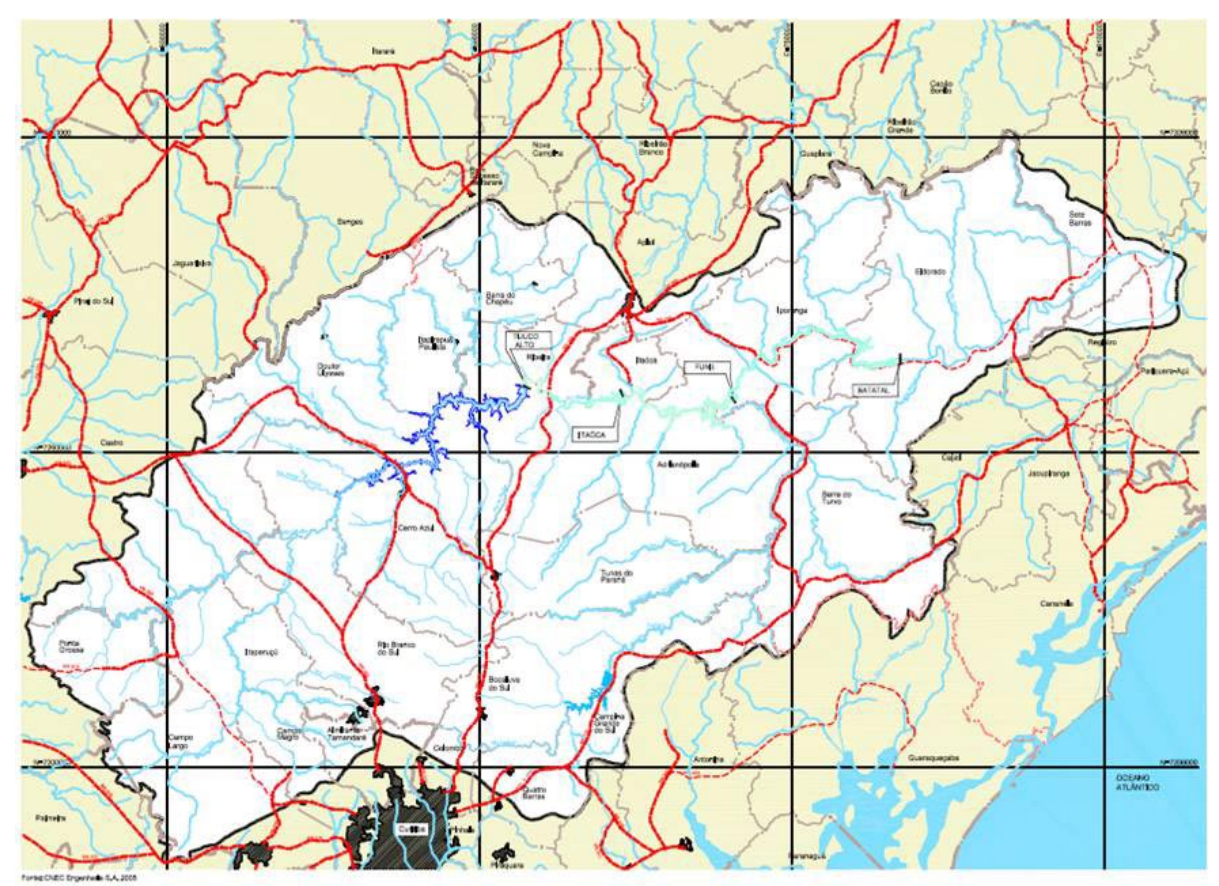

Imagem extraída de apresentação em Power Point da CNEC sobre o projeto Tijuco Alto.

Chamamos atenção para o clima político das audiências, porque nos municípios onde serão sentidos os efeitos da construção e operação da hidrelétrica de maneira mais contundente, as audiências públicas não tiveram o grau de conflito observado em Eldorado e Registro, localizados a jusante do empreendimento e que em tese, não serão impactados diretamente pela UHE Tijuco Alto.

Isso sem mencionar o fato, já discutido anteriormente, de que a região onde estão os municípios que compõem a ADA, tem sido impactada pela falta de definição em relação ao empreendimento nestes quase 20 anos em que o processo se arrasta, com êxodo populacional e diminuição da taxa de emprego.

A participação cidadã no ciclo de debates se deu através de grupos sociais e políticos organizados e já posicionados em relação ao empreendimento, com demandas específicas e que poderiam ter contribuído com o planejamento do empreendimento ou ter suas dúvidas e críticas incorporadas ao diagnóstico socioambiental ou suas observações consideradas pelas propostas mitigadoras muito antes das audiências públicas, que se realizaram três anos e meio após o pedido de abertura do processo de licenciamento. 


\begin{tabular}{|c|c|c|c|}
\hline \multicolumn{4}{|c|}{ Tabela $4^{*}$ - Posição em relação à UHE a partir das intervenções (\%) } \\
\hline & Favorável & Desfavorável & $\begin{array}{c}\text { Não se } \\
\text { Posicionou }\end{array}$ \\
\hline Entidades Mov. Social & 0 & 98,3 & 1,7 \\
\hline $\begin{array}{l}\text { Coletivo Educador / Coletivo Jovem } \\
\text { Caiçara }\end{array}$ & 0 & 100 & 0 \\
\hline MOAB & 0 & 96 & 4 \\
\hline MST & 0 & 100 & 0 \\
\hline Sindisaúde & 0 & 100 & 0 \\
\hline Astraff & 0 & 100 & 0 \\
\hline Cidadãos & 21,2 & 39,4 & 39,4 \\
\hline Munícipes & 21,9 & 37,5 & 40,6 \\
\hline Indígena & 0 & 100 & 0 \\
\hline Políticos & 34,6 & 30,7 & 34,6 \\
\hline Vereadores & 10 & 50 & 40 \\
\hline Prefeitos & 44,4 & 11,1 & 44,4 \\
\hline Deputados & 57,1 & 28,6 & 14,3 \\
\hline ONGs Sócioambientalistas & 0 & 93,7 & 6,3 \\
\hline CEDEA & 0 & 100 & 0 \\
\hline ISA & 0 & 100 & 0 \\
\hline SOS & 0 & 75 & 25 \\
\hline IDESC & 0 & 100 & 0 \\
\hline Outras ONGs & 0 & 100 & 0 \\
\hline Órgãos de Estado & 7,7 & 0 & 92,3 \\
\hline Ministério Público & 0 & 0 & 100 \\
\hline IBAMA & 0 & 0 & 100 \\
\hline MME & 33,3 & 0 & 66,7 \\
\hline Empreendedor & 100 & 0 & 0 \\
\hline CBA/CNEC & 100 & 0 & 0 \\
\hline Empresários & 66,7 & 16,7 & 16,7 \\
\hline ABAVAR & 100 & 0 & 0 \\
\hline Produtor Rural & 50 & 0 & 50 \\
\hline Empresário de Turismo & 0 & 100 & 0 \\
\hline Outros & 9,1 & 63,6 & 27,3 \\
\hline Especialista & 0 & 100 & 0 \\
\hline Unicamp & 0 & 100 & 0 \\
\hline Pergunta escrita não identificada & 11,1 & 55,5 & 33,3 \\
\hline
\end{tabular}

* Os percentuais de IBAMA, MME e CBA/CNEC são correpondentes a intervenções no momento de abertura das audiências, antes da apresentação do EIA e do início dos debates

A análise da tabela 4 explicita com clareza a posição de cada um dos grupos políticos e sociais que estiveram nas audiências. A construção da UHE foi defendida pela CBA/CNEC, pelas intervenções feitas por empresários e parte da classe política que esteve dividida sobre a questão.

O movimento social organizado e os cidadãos que participaram sem pertencer a algum grupo foram majoritariamente contrários a UHE, inclusive aqueles que fizeram perguntas escritas e não foi possível identificá-los. 
Esses dados deixam claro que os grupos sociais, econômicos e políticos que participaram das audiências tinham um posicionamento e o levaram aos plenários, onde em lugar do diálogo, o que houve foram diversos monólogos.

Há falas que foram repetidas do início ao fim do ciclo de audiências, por parte de todos os lados, de modo que parece razoável imaginar que se essas agendas pudessem ter conversado durante os três anos que antecedeu o debate nas audiências, teriam alguma chance de acerto. Difícil imaginar que demandas represadas duranteo mesmo tempo possam resolver-se em plenárias com direito a 3 minutos para fala e 2 para réplica e tréplica.

O clima de confronto foi animado por uma série de questões recorrentes de ambos os lados:

\begin{tabular}{|l|c|}
\hline $\begin{array}{l}\text { Tabela } 5^{*} \text { - Sentidos Construídos com mais freqüência99 pelos } \\
\text { interesses locais }\end{array}$ & $\%$ \\
\hline Moradores não querem sair onde estão/Povo do Vale do Ribeira é contra UHE & 12,1 \\
\hline $\begin{array}{l}\text { UHE beneficia apenas um único interesse, Antônio Ermírio e ou CBA. Recursos } \\
\text { Naturais não devem ser privatizado }\end{array}$ & 12,1 \\
\hline $\begin{array}{l}\text { EIA/RIMA é frágil e ou tem problemas. Qualidade do Estudo de Impacto Ambiental é } \\
\text { questionável }\end{array}$ & 9,8 \\
\hline UHE é risco ambiental, entre outras questões por conta do solo Kárstico & 9,8 \\
\hline Como ficarão os agricultores atingidos? / As condições dos atingidos serão mantidas ? & 8,7 \\
\hline $\begin{array}{l}\text { Desenvolvimento sustentável do Vale do Ribeira não contempla barragem / Governo } \\
\text { federal tem programas que valorizam Desenvolvimento sustentável no Vale do Ribeira } \\
\text { / Agenda XXI local rejeitou barragens }\end{array}$ & 8,7 \\
\hline Empregos gerados pela UHE (não) compensam impactos ambientais (?) & 8,1 \\
\hline UHE não faz controle de enchentes & 8,1 \\
\hline $\begin{array}{l}\text { Rio Ribeira tem valor cultural / Rio Ribeira está para ser declarado Patrimônio da } \\
\text { Humanidade / Rio Ribeira é patrimônio público }\end{array}$ & 7,5 \\
\hline Terras compradas pela CBA e paradas há 20 anos causam prejuízos à população & 7,5 \\
\hline $\begin{array}{l}\text { Vale do Ribeira/Rio Ribeira é reserva da Mata Atlântica no país, por isso tem que ser } \\
\text { preservado }\end{array}$ & 6,3 \\
\hline $\begin{array}{l}\text { CBA construiu 7 UHE`s em Juquiá e não produziu melhora de vida no município / } \\
\text { UHE`s do Rio Juquiá não contém enchente / Hidrelétricas do Juquiá se inserem no } \\
\text { contexto da análise de Tijuco Alto }\end{array}$ & 5,8 \\
\hline CBA/CNEC enrola e não responde ou mente & 5,2 \\
\hline
\end{tabular}

* As intervenções normalmente tratavam de mais de um assunto. Para cada fala registramos até 10 sentidos construídos, motivo pelo qual a soma das porcentagens poderá ser maior que 100

\footnotetext{
${ }^{99}$ As tabelas que apresentam os sentidos construídos com mais frequiência não estabelecem relação de importância entre estes entre si, e entre estes e uma série de outros expressados nas intervenções, mas com menor freqüência. As tabelas têm tão somente a função de informar os sentidos ditos um maior número de vezes.

${ }^{100}$ Consideramos como "Interesses Locais" o conjunto dos grupos sociais, políticos e econômicos da região, além dos cidadãos que falaram sem estar vinculado a nenhum grupo organizado. Fazem parte também desse grupo, as instituições que não são propriamente da região, mas que têm projetos, programas ou alguma atividade econômica ou socioambiental neste. Especificamente em relação ao licenciamento da UHE Tijuco Alto, consideramos interesses locais os cidadãos, as entidades do movi. social, ONGs, políticos, empresários e pesquisadores que intervieram durante as audiências.
} 


\begin{tabular}{|c|c|}
\hline $\begin{array}{l}\text { Tabela } 6^{*} \text { - Sentidos construídos mais frequentes nas intervenções da } \\
\text { CBA/CNEC }\end{array}$ & $(\%)^{*}$ \\
\hline $\begin{array}{l}\text { Reassentamento rural vai ser feito com base em opções diferentes e ou melhorar vida } \\
\text { das pessoas. Estão previstas terras para não proprietários. Atingidos contarão com } \\
\text { suporte jurídico próprio }\end{array}$ & 10,5 \\
\hline Desapropriação irá quantificar benfeitorias e pessoas serão assistidas & 9,6 \\
\hline $\begin{array}{l}\text { Chumbo se precipita devido as condições químicas da água. Chumbo não } \\
\text { contaminará o rio que terá boa qualidade }\end{array}$ & 9,6 \\
\hline $\begin{array}{l}\text { UHE fará controle de enchentes, porque projeto foi pensado tb para isso. O lago terá } \\
10 \mathrm{~m} \text { a espera de cheia, referencia de observação de } 100 \text { anos de chuva }\end{array}$ & 7,9 \\
\hline $\begin{array}{l}\text { CBA se compromete a ofertar empregos no Vale com preferencia para os municípios } \\
\text { impactados }\end{array}$ & 7 \\
\hline $\begin{array}{l}\text { Programas compensatórios (saúde, educação, etc) vão produzir melhoras nos } \\
\text { municípios impactados }\end{array}$ & 7 \\
\hline $\begin{array}{l}\text { UHE vai gerar } 60 \text { empregos diretos na operação, } 60 \text { e } 1700 \text { durante construção. CBA } \\
\text { assume compromisso público com a contratação, na região, de } 2 / 3 \text { da mão de obra } \\
\text { necessária para construção. }\end{array}$ & 6,1 \\
\hline $\begin{array}{l}\text { CBA emprega } 9000 \text { pessoas e exporta } 40 \% \text { de produtos já manufaturados. / Interesse } \\
\text { da CBA na construção da UHE é produzir alumínio, por isso quer fazer UHE }\end{array}$ & 5,3 \\
\hline $\begin{array}{l}\text { Há normas sobre momento do enchimento do lago. O rio não ficará seco, mesmo } \\
\text { durante o enchimento quando haverá vazão } 15 \mathrm{~m} / \mathrm{s} \text { no pé da barragem e contribuição } \\
\text { de outros rios afluentes }\end{array}$ & 5,3 \\
\hline Terras foram compradas por determinação do DNAEE, no $1^{\circ}$ licenciamento & 5,3 \\
\hline UHE é estrutura segura, risco de sismos e rompimento são baixos & 5,3 \\
\hline
\end{tabular}

* As intervenções normalmente tratavam de mais de um assunto. Para cada fala registramos até

10 sentidos construídos, motivo pelo qual a soma das porcentagens poderá ser maior que 100

Uma análise das tabelas 5 e 6 revelam que as falas repetidas com maior frequencia durante as audiências dizem respeito ao empreendimento e às questões relacionadas aos impactos, programas compensatórios e mitigatórios. Esta constatação se confronta com certa fala comum no governo, no meio empresarial e presente no estudo do Banco Mundial, de que na hora do licenciamento a discussão desvia-se para assuntos que não devem ser tratados no âmbito do licenciamento.

Não que não tenha havido falas que tentaram discutir assuntos de interesse da sociedade, mas que não dizem respeito a Tijuco Alto, houve, mas o debate durante o ciclo de plenárias esteve focado nos assuntos relacionados ao projeto e suas características técnicas, ambientais e nos programas destinados a mitigar e compensar os danos causados pela UHE, caso seja licenciada.

A discussão a respeito de um projeto de desenvolvimento sustentável para a região do Vale do Ribeira que leve em conta suas especificidades socioambientais e a oposição dessa perspectiva a um projeto que privilegia a apropriação dos recursos naturais por um único interesse foi feita em 34,6\% das intervenções 
dos interesses locais. O debate a respeito da mudança compulsória e dos prejuízos causados a inúmeras famílias pela controversa ${ }^{101}$ aquisição de terras pela CBA na década de 90 foi feito por 28,3\% das falas. Questões relacionadas aos riscos ambientais da UHE em relação à fragilidade do solo Karst ou da inadequação das UHEs para conter enchentes foram abordadas em 23,7\% das falas.

As fragilidades do EIA e a dificuldade da CNEC/CBA em responder o que as pessoas queriam que ela respondesse foram expressas em $15 \%$ das falas, enquanto 8,1\% das intervenções afirmaram que os empregos gerados pela UHE não compensavam os impactos causados.

A CBA/CNEC tratou do tema referente aos programas de mitigação e compensação relacionados aos deslocamentos compulsórios em 32,4\% de suas intervenções. As questões relacionadas à contaminação da água, risco de abalos sísmicos, controle de enchentes e vazão do Rio no momento de enchimento do lago foram tratadas em 28,1\% das intervenções dos consultores da CNEC e corpo diretivo da CBA. Pouco mais de 5\% das intervenções defenderam a indústria de alumínio, sua solidez institucional e o papel estratégico que desempenha para o país.

A análise das falas dos diversos atores sociais no conjunto, como vimos acima, ou separadamente, evidencia que cada grupo político ou social trouxe ao debate algum aspecto que lhe é mais interessante de ser discutido. Houve temas comuns e abordados sob pontos de vista semelhantes, mas havia agendas específicas que foram trazidas ao público durante as audiências.

Fato que reforça nosso ponto de vista de que fazer o debate público a respeito do empreendimento só na audiência pública só traz tensão ao licenciamento, uma vez que uma série de questões repetidas a exaustão de um lado e respondidas também a exaustão, do outro, poderiam ter sido debatidas em ambiente mais propício a troca de impressões e ao convencimento mútuo.

A tabela 7 é um bom indicador do que estamos dizendo. As falas dos militantes do Coletivo de Educadores do Lagamar abordaram muitos assuntos, mas, os mais freqüentes tinham relação direta com a

${ }^{101}$ Durante o primeiro licenciamento, a CBA comprou inúmeros lotes na área onde ficará o reservatório. Há denúncias de que houve muita pressão para que os terrenos fossem vendidos, muito deles a preços irrisórios. Os não proprietários não tiveram seus direitos reconhecidos. Em relação a essa situação a CBA respondeu que só uma pessoa tem autorização para negociar terrenos em nome da indústria e não pode se responsabilizar pelo que outros fizeram. Como já dito anteriormente, neste texto, Ronaldo Crusco algumas vezes chamou atenção para os novos tempos e que os procedimentos agora (referindo-se ao segundo licenciamento), serão diferentes e reconhecerão não proprietários e que pessoas que tiveram que sair das terras na década de 90 serão indenizadas. 
especificidade de um grupo de Cananéia formado por biólogos, pesquisadores marinhos, militantes da área de saúde e educadores socioambientais.

As falas do Coletivo de Educadores e do Coletivo Jovem Caiçara chamaram a atenção para o impacto do empreendimento no ambiente estuarino e para a necessidade de se fazer o debate da UHE na região estuarina. O debate ambiental a respeito da especificidade do bioma Mata Atlântica e da incompatibilidade do projeto da CBA com uma agenda de desenvolvimento sustentável do Vale do Ribeira também teve destaque nas falas do grupo.

\begin{tabular}{|l|c|}
\hline $\begin{array}{l}\text { Tabela 7 - Sentidos construídos mais frequentes pelo Coletivo de } \\
\text { Educadores do Lagamar (Coletivo Educador / Coletivo Jovem Caiçara) }\end{array}$ & (\%) \\
\hline $\begin{array}{l}\text { UHE vai desempregar e ou impactar 2200 famílias na região do lagamar/ Pequenas } \\
\text { variações na salinidade da região estuarina podem comprometer comunidades que se } \\
\text { alimentam no estuário / É Impossível que não haja impacto algum no complexo estuarino }\end{array}$ & 32 \\
\hline $\begin{array}{l}\text { Vale do Ribeira/Rio Ribeira é reserva da Mata Atlântica no país, por isso tem que ser } \\
\text { preservado }\end{array}$ & 28 \\
\hline $\begin{array}{l}\text { Audiência em Cananéia é legítima e deveria ocorrer. Foram arrecadadas mais de 1000 } \\
\text { assinaturas. Ministério Público também solicitou. Não há justificativa para não realizá-la }\end{array}$ & 24 \\
\hline Moradores não querem sair de onde estão/ Povo do Vale do Ribeira é contra UHE & 24 \\
\hline $\begin{array}{l}\text { Rio Ribeira tem valor cultural / Rio Ribeira está para ser declarado Patrimônio da } \\
\text { Humanidade / Rio Ribeira é patrimônio público }\end{array}$ & 20 \\
\hline $\begin{array}{l}\text { Desenvolvimento sustentável do Vale do Ribeira não contempla barragem / Governo } \\
\text { federal tem programas que valorizam Desenvolvimento sustentável no Vale do Ribeira } \\
\text { / Agenda XXI local rejeitou barragens }\end{array}$ & 16 \\
\hline $\begin{array}{l}\text { UHE beneficia apenas um único interesse, Antônio Ermírio e ou CBA. Rio/ Recursos } \\
\text { Naturais não deve ser privatizado }\end{array}$ & 16 \\
\hline $\begin{array}{l}\text { CBA construiu 7 UHE`s em Juquiá e não produziu melhora de vida no município / UHE`s } \\
\text { de Juquiá não contém as enchentes / Juquiá se insere no contexto da análise de Tijuco Alto }\end{array}$ & 12 \\
\hline Empregos gerados pela UHE (não) compensam impactos ambientais? & 12 \\
\hline $\begin{array}{l}\text { Estudo ou RIMA é frágil e ou tem problemas. Qualidade do Estudo de Impacto } \\
\text { Ambiental questionável }\end{array}$ & 12 \\
\hline Impactos são indiscutíveis. Como afirmar que eles são mínimos? & 12 \\
\hline $\begin{array}{l}\text { UHE é risco ambiental, entre outras questões por conta do solo Kárstico / UHE } \\
\text { contribui para causas aquecimento global }\end{array}$ & 12 \\
\hline
\end{tabular}

* As intervenções normalmente tratavam de mais de um assunto. Para cada fala registramos até 10 sentidos construídos, motivo pelo qual a soma das porcentagens poderá ser maior que 100

A análise das intervenções dos militantes do MOAB (tabela 8) também revela forte sintonia entre as falas mais freqüentes e as especificidades de um grupo formado majoritariamente por remanescentes de quilombolas, com forte ligação com a terra e sabedores dos inúmeros problemas que essas populações têm tido com outros empreendimentos hidrelétricos. O MOAB foi quem mais expôs críticas em 
relação ao licenciamento e a dificuldade que tiveram em se fazer ouvir no processo.

Os militantes do Movimento dos Ameaçados por Barragens trouxeram a discussão questões concretas em relação ao empreendimento: como será a travessia da balsa e a captação de água com a diminuição da vazão do Rio durante enchimento do reservatório, quais garantias existiam em relação aos compromissos assumidos e o temor de o empreendimento provocar mudanças definitivas em seus modos de vida.

\begin{tabular}{|l|c|}
\hline Tabela 8 - Sentidos construídos mais frequentes nas intervenções do MOAB & (\%) \\
\hline UHE não faz controle de enchentes & 28 \\
\hline Moradores não querem sair de onde estão/ Povo do Vale do Ribeira é contra UHE & 24 \\
\hline CBA/CNEC desconversa, (enrola e) não responde ou mente & 20 \\
\hline $\begin{array}{l}\text { CBA construiu 7 UHE`s em Juquiá e não produziu melhora de vida no município / } \\
\text { UHE`s juquiá não contém enchente / Juquiá se insere no contexto da análise de } \\
\text { Tijuco Alto }\end{array}$ & 20 \\
\hline $\begin{array}{l}\text { Audiência Pública/ Licenciamento tem formato que privilegia empreendedor e } \\
\text { dificulta esclarecimento e ou participação do povo }\end{array}$ & 16 \\
\hline $\begin{array}{l}\text { Quando lago tiver enchendo vai diminuir vazão do Rio. Vai impactar região estuarina } \\
\text { ou travessia da balsa }\end{array}$ & 16 \\
\hline Terras compradas pela CBA e paradas há 20 anos causam prejuízos à população & 16 \\
\hline $\begin{array}{l}\text { As comunidades tradicionais vivem em processo de interação com a natureza. A UHE } \\
\text { nos impactará de qualquer jeito }\end{array}$ & 12 \\
\hline $\begin{array}{l}\text { Captação de água já é difícil, mas com enchimento do rio, teremos problemas para } \\
\text { captar, a solução demandará custos e não há previsão de mitigação disso }\end{array}$ & 12 \\
\hline $\begin{array}{l}\text { Como serão cumpridos os compromissos assumidos. Quais garantias de cumprimento } \\
\text { das propostas de mitigação / Como sociedade vai acompanhar? }\end{array}$ & 12 \\
\hline $\begin{array}{l}\text { Ibama andou nos carros da CNEC / Ibama ficou passeando com Ibama e não } \\
\text { conversou com comunidades / Relação entre Ibama e CBA/CNEC é muito intíma }\end{array}$ & 12 \\
\hline UHE não vai trazer benefícios socias. Não terá impacto positivo no IDH & 12 \\
\hline UHE vai acabar com comunidades tradicionais & 12 \\
\hline
\end{tabular}

* As intervenções normalmente tratavam de mais de um assunto. Para cada fala registramos até 10 sentidos construídos, motivo pelo qual a soma das porcentagens poderá ser maior que 100

Enfim, a análise dos diversos discursos trazidos ao debate durante o ciclo de audiência corrobora com nosso ponto de vista, de que muitas das questões poderiam chegar suficientemente discutidas nas audiências, contribuindo para a qualidade de posicionamentos trazidos ao público a partir de situações concretas e comprovadas durante os debates. Pois, muitas das intervenções foram feitas e respondidas sem que houvesse condições concretas de serem discutidas a fundo. Seja pela complexidade do assunto, seja pela falta de instrumentos que pudessem ser utilizados para esclarecer fatos. 
Da maneira como se deram os debates, o princípio que orientou o posicionamento dos atores do movimento social e contrários a barragem foi a desconfiança. As audiências estiveram claramente contaminadas pelo histórico do licenciamento.

Pairou sobre o ciclo de discussão a repercussão da negativa de o movimento social ter podido participar do licenciamento desde a definição do $\mathrm{TR}^{102}$. A tensão que se acumulou durante o processo de licenciamento reverberou no ciclo de debates na fala do presidente do MOAB, José Rodrigues, que ao ser convidado a compor a mesa de abertura da plenária no município de Eldorado, disse que não falaria dali porque não iria legitimar um processo que lhes foi negado participação.

Ainda que as análises das falas indiquem total coerência entre as intervenções e as especificidades de cada grupo, não nos passou despercebido o fato de que todos os atores já foram para o debate com um conjunto de falas “pré-fabricadas”. Poucas questões saíram de um repertório previsto.

Houve um caso concreto de omissão do EIA em relação ao diagnóstico de uma determinada área ocupada por uma comunidade quilombola que o advogado do ISA, Raul Telles do Valle, trouxe ao debate e o engenheiro chefe da CNEC concordou que a situação merecia atenção. Na primeira audiência, um professor ligado ao MOAB questionou o impacto das UHEs da CBA localizadas em Juquiá sobre o IDH do município. Houve claro embaraço na resposta.

Nomais, perguntas erepostas foram previsíveis e mesmo aquelas ditas commenos frequiênciaforam repetitivas.

\subsection{O CICLO DE AUDIÊNCIAS - UM CIRCO ITINERANTE}

O ciclo de audiências Públicas teve características muito parecidas a de um circo:

Foi itinerante, a infra-estrutura locada (aparelhagem de som, cadeiras, infra-estrutura do lanche, equipamentos de filmagem) era fácil de montar e desmontar. No final de cada uma das plenárias, mesmo

\footnotetext{
${ }^{102}$ Em julho de 2004, o MOAB encaminhou carta ao IBAMA solicitando reunião com o órgão licenciador a fim de discutirem contribuições do movimento para a definição do Termo de Referência - TR. O IBAMA ignorou a solicitação e definiu o TR sem ouvir o MOAB. Esse processo foi melhor descrito e analisado no cap. 3 e no Artigo "O Licenciamento Ambiental e o Novo Ambiente Político e Cultural do Pós-Ditadura: O Caso da UHE Tijuco Alto”, constante na bibliografia.
} 
antes de encerrada as discussões ${ }^{103}$, uma equipe rapidamente desmontava e carregava dois caminhões-baú que fizeram o transporte de todo o aparato.

Figura 23 - Infra-estrutura das audiências foi móvel. Caminhões sendo carregados ao término da audiência de Adrianópolis

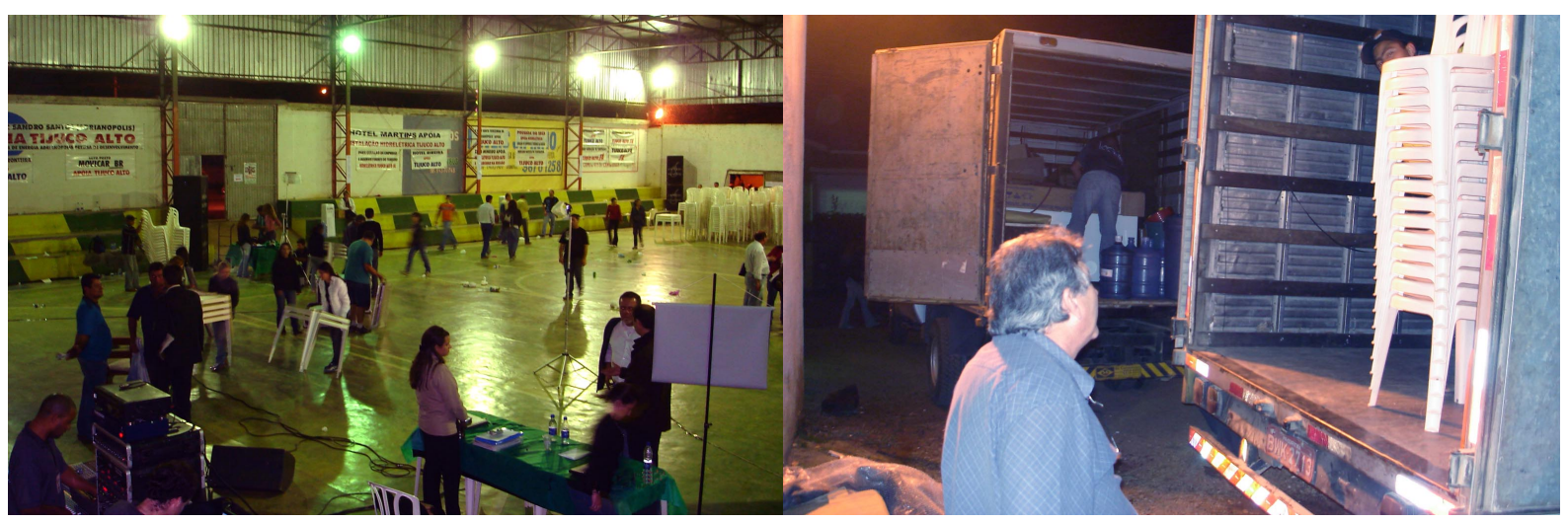

Fotos: Alexandre do Nascimento Souza - Adrianópolis - 8/07/2007

A infra-estrutura foi garantida pela empresaEstúdio Grafite do município de Apiaí, que montou, desmontou e transportou toda a infra-estrutura das audiências, fez oregistro em áudioe vídeo dos debates, contratou e serviu olanche além das meninas que circulavam o plenário distribuindo e recolhendo os formulários das perguntas.

Em todos os debates, a CBA/CNEC instalou no fundo dos espaços ${ }^{104}$ onde se realizaram as audiências 8 banners presos a cavaletes que publicizavam as atividades da CBA junto às comunidades dos 5 municípios diretamente afetados. As fotos constantes nos banners mostravam principalmente imagens de atividades em escolas.

\section{Figura 24 - Banners com fotos das atividades Figura 25 - Bancada com foto aérea da Área nas escolas - Presente em todas as Audiências de Influência Direta -}

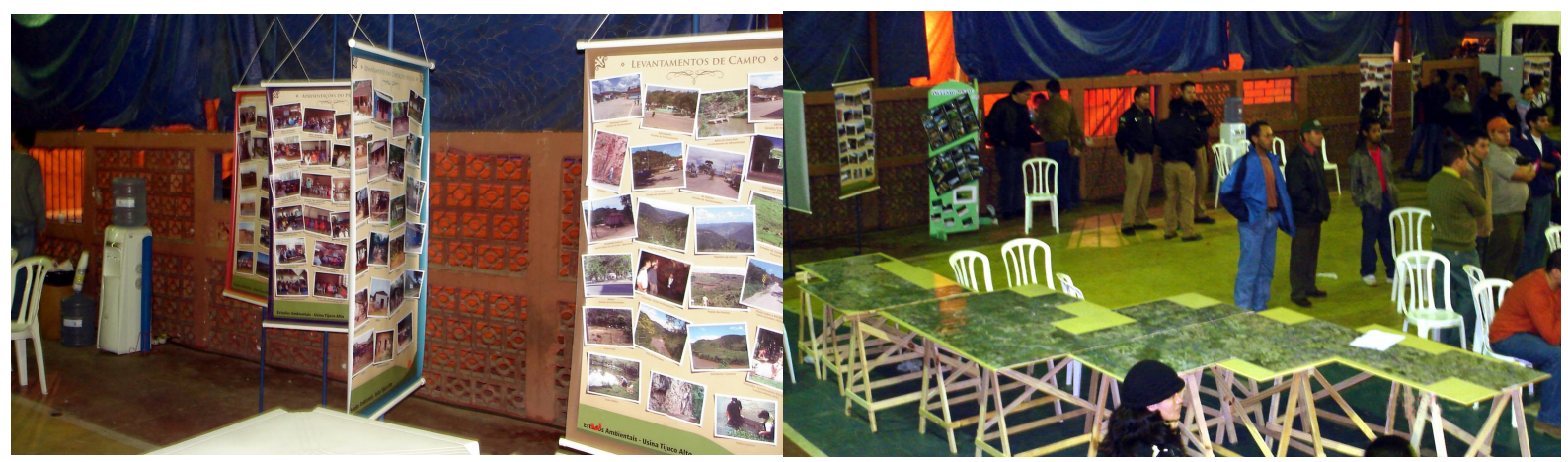

Fotos: Alexandre do Nascimento Souza - Cerro Azul - 06/07/07

\footnotetext{
${ }^{103} \mathrm{Na}$ medida em que o plenário ia ficando vazio

${ }^{104}$ As audiências foram realizadas nos Ginásios Municipais de Cerro Azul, Ribeira, Adrianópolis e Eldorado. Em Registro, a plenária aconteceu na no salão de festas do Clube KKK.
} 
Próximo aos banners foi instalada uma bancada grande onde constava a imagem de satélite ou foto aérea do curso do Rio Ribeira do Iguape a ser modificado. Durante o intervalo, quando era servido o lanche e as inscrições para as perguntas do público iniciadas, o engenheiro florestal da CNEC, Manuel Domingues, se postava próximo a bancada e explicava o projeto para aqueles que se aproximavam.

Um dos aspectos mais interessantes das audiências públicas (croquis abaixo) foi o fato de que mesmo os debates tendo ocorrido em espaços diferentes, a posição espacial dos principais atores em relação à mesa foi a mesma nas cinco plenárias. Naúltima plenária em registro o Coletivo de Educadores do Lagamar trocou a lateral esquerda do salão onde se postara nos quatro (4) debates anteriores e ficou no fundo do lado direito.

Em Eldorado, como estava em casa, o MOAB ocupou bastante espaço do ginásio, no entanto, suas principais lideranças continuaram à frente, do lado esquerdo de frente para a mesa. O staff da CBA/ CNEC ficou no mesmo lugar em todas as plenárias, na lateral direita do plenário, meio de lado, meio de frente à mesa que conduzia os trabalhos.

Esse fato é indicativo preciso do que de fato ocorreu nas plenárias. Ao manter a mesma disposição espacial nos diferentes ambientes, os diversos atores do processo de licenciamento em disputa deram demonstração de que na verdade não sentavam para debater e sim se posicionavam para duelar, daí o fato de cada um se postar no local onde de alguma forma se sentia mais confortável e ou mais seguro.

Durante as audiências, o movimento social contrário à UHE trocavam uma ou outra figurinha, comentavam a respeito dos acontecimentos, mas cada um teve sua performance individualizada, quando era necessário protestar por algum motivo em particular sabiam que havia uma solidariedade do coletivo em relação ao mesmo propósito, mas era nítido que cada grupo ou ator social tinha sua orientação própria.

Apesar de unidos pelo mesmo objetivo, cada um desses tinha o seu "modus operandis", a sua maneira de se colocar, a sua claque, quando foi o caso e principalmente sua própria demanda, fosse ela concreta em relação aos impactos ou discursiva.

Em alguns momentos tive a nítida sensação de que no ambiente das audiências públicas existe um pouco do que encontramos nos parlamentos, onde situação e oposição divergem e às vezes se digladiam, mas fora do ambiente da disputa e dos holofotes, principalmente, buscam ter canais abertos de diálogo. Nesse sentidoé 


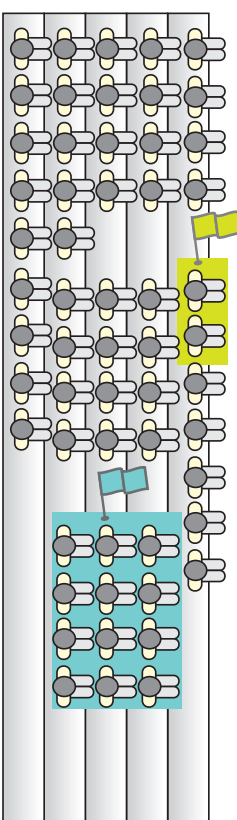

S.O.S Mata Atlântica

Pu Coletivo de Educadores do Lagamar

Paura/CEDEA
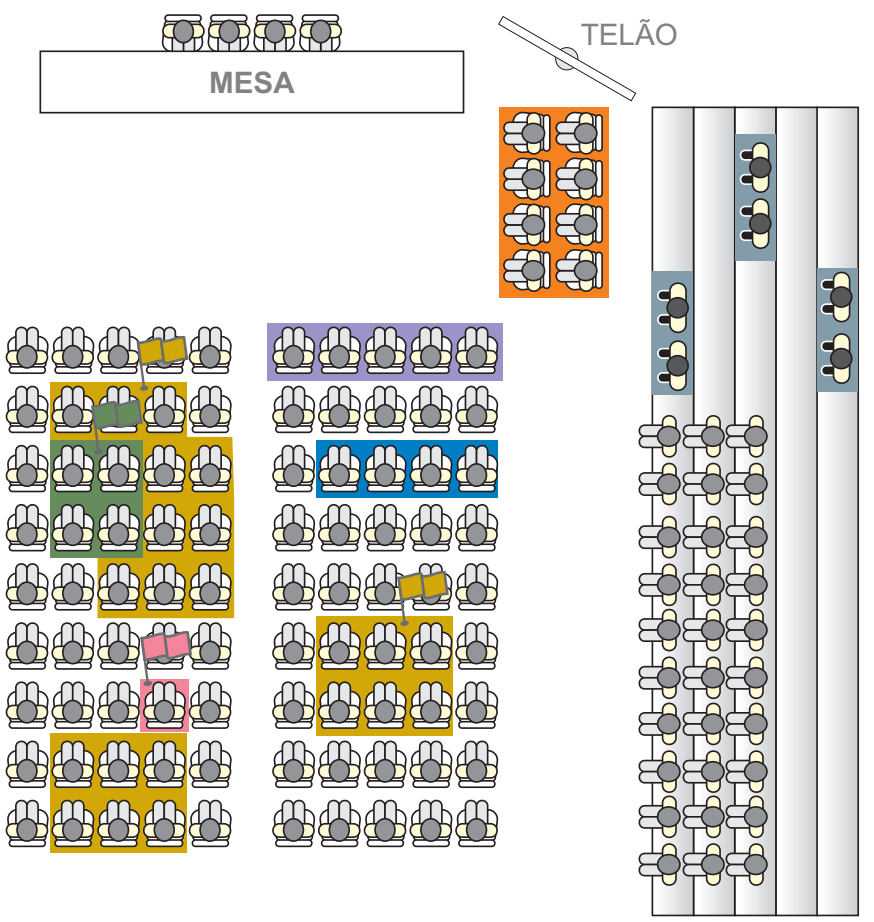

$83 \Leftrightarrow 8$

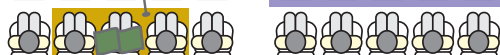
COS 803,80360360 8030303803

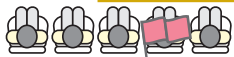
6030360360 803603

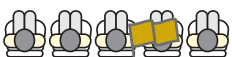
803803

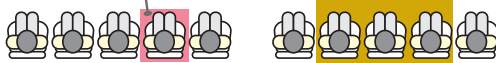

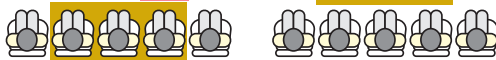

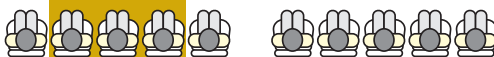

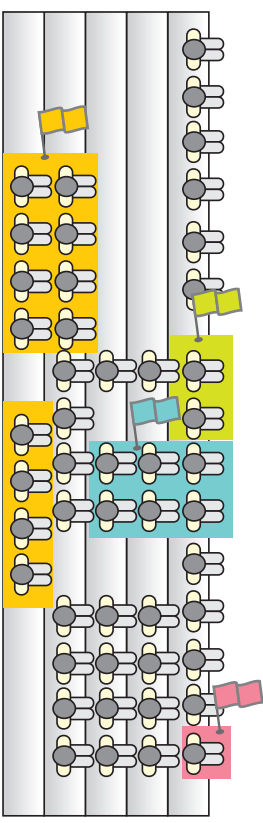 \\ [u] S.O.S Mata Atlântica \\ $0]$ Mulheres e Crianças que apoiam Tijuco Alto \\ P] Coletivo de Educadores do Lagamar

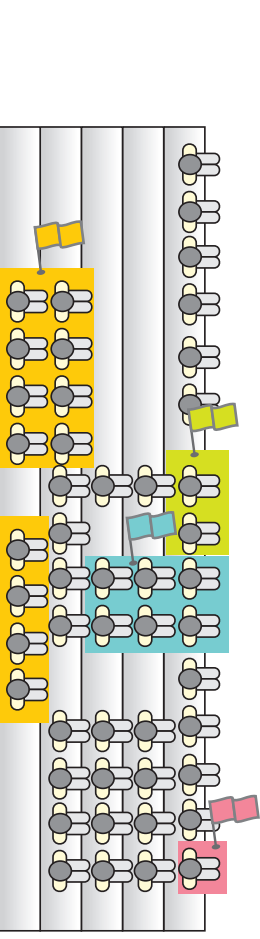
$\square$ Políticos
Ministério Público Federal - MPF
$\square$ Staff CBA/CENEC

$\square$ Seguranças à paisana

Instituto Sócio Ambiental - ISA

Movimento dos Ameaçados por Barragem - MOAB
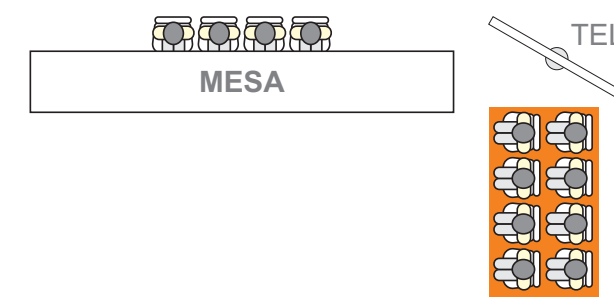

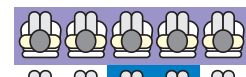

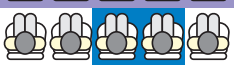
Q \&O 口हि

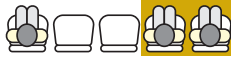
QD\&OQ

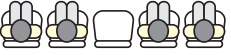
口क्षिप्य

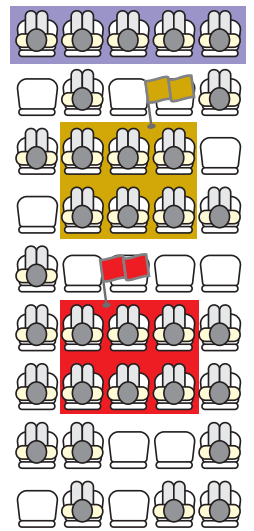
ELÃO

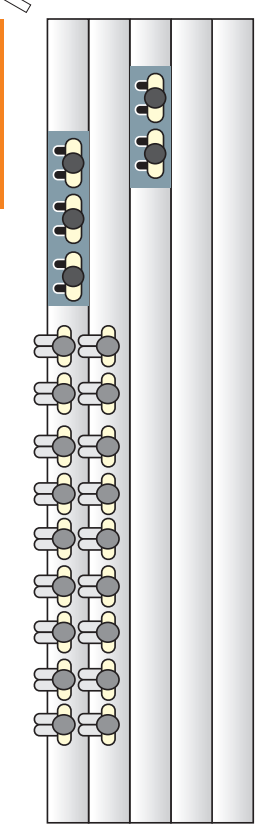
$\square$ Políticos
$\square$ Ministério Público Federal - MPF
$\square$ Staff CBA / CENEC
Laura / CEDEA

Seguranças à paisana

Instituto Sócio Ambiental - ISA

Movimento dos Ameaçados por Barragem - MOAB

Juventude do MST 


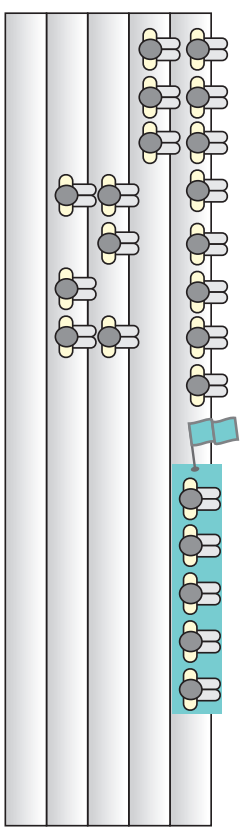

S.O.S Mata Atlântica
Coletivo de Educadores do
Lagamar
Laura / CEDEA

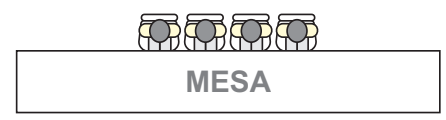<smiles>C=CCCCCC</smiles>

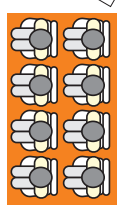

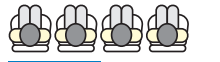

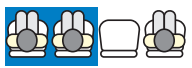

(2)

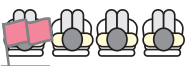
Q8) $D=08$

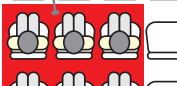

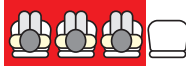

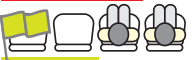

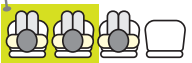

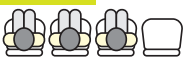

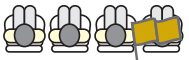
860; (6)

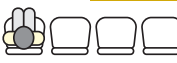
segen

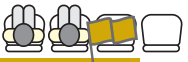

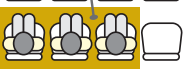
0

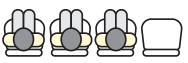
时

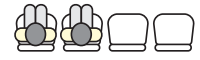
口曰8

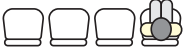

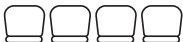

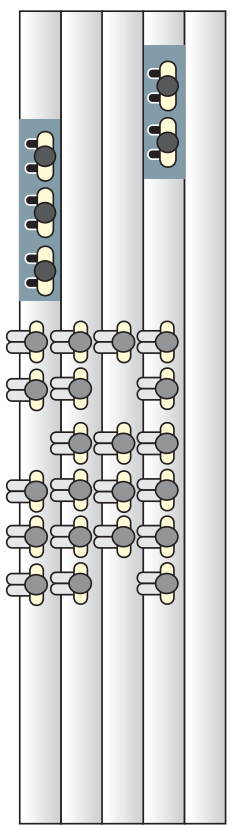

$$
\begin{aligned}
& \square \text { Ministério Público Federal - MPF } \\
& \square \text { Staff CBA / CENEC } \\
& \square \text { Movimento dos Ameaçados por } \\
& \text { Barragem - MOAB }
\end{aligned}
$$$$
\square \text { Seguranças à paisana }
$$

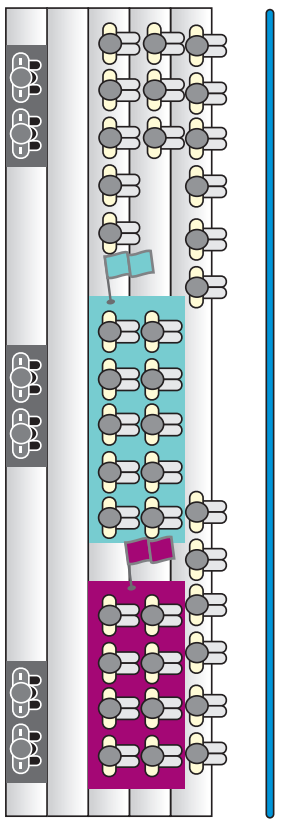

\footnotetext{
S.O.S Mata Atlântica

Laura / CEDEA

[u] Coletivo de Educadores do Lagamar

Jovens Cananea
}
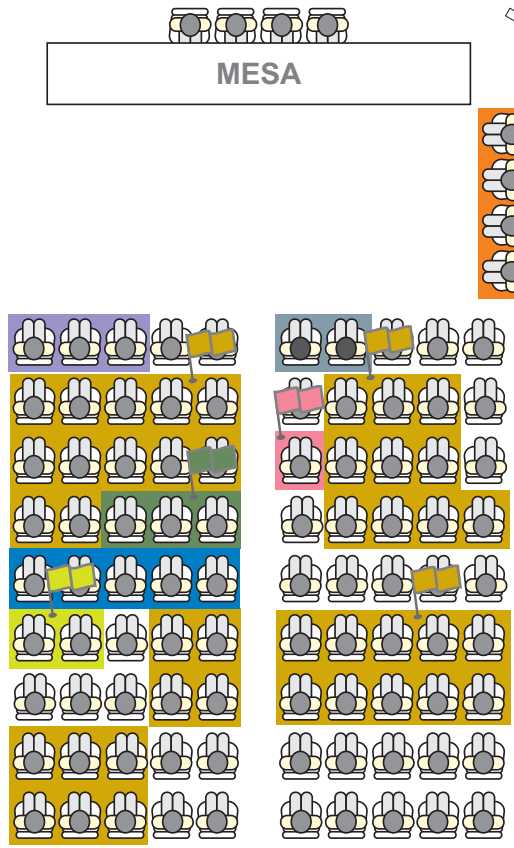
$\square$ Políticos
$\square$ Ministério Público Federal - MPF
$\square$ Staff CBA/ CENEC
Movimento dos Ameaçados por
Barragem - MOAB

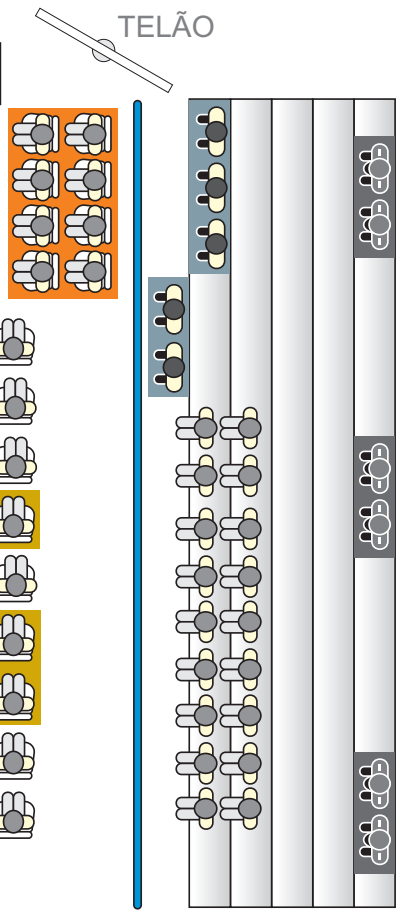

$\square$ Seguranças à paisana

$\square$ Seguranças Fardados

Instituto Sócio Ambiental - ISA 


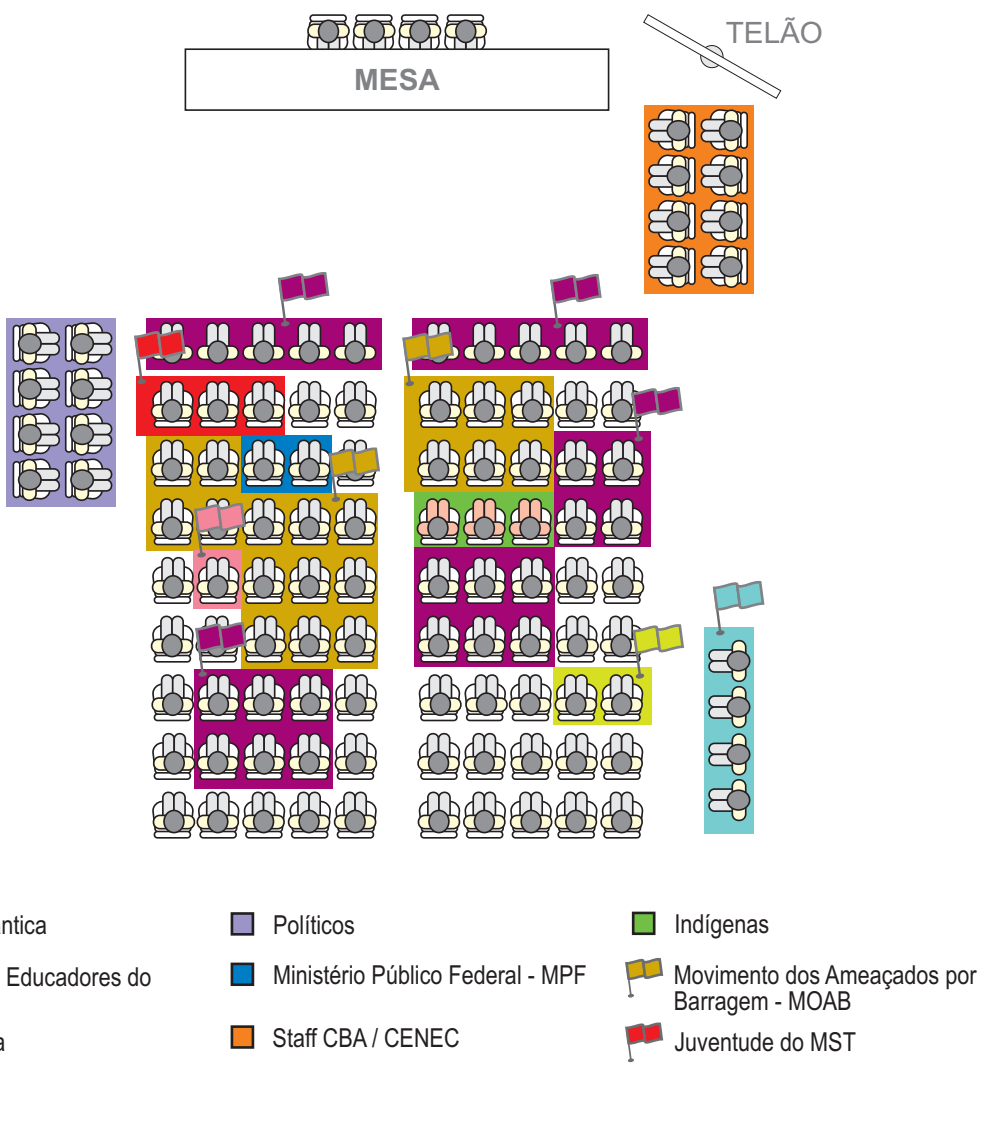

que foi explícito durante todo o ciclo de audiências a postura de dois diretores da CBA sempre solícitos a abordagens e de em alguns momentos até se dirigirem a algumas pessoas na tentativa de estabelecer diálogo.

Na audiência de Adrianópolis, quando não houve praticamente confronto e o clima entre o Staff da $\mathrm{CBA} / \mathrm{CNEC}$ e os grupos sociais presentes beirou a cordialidade, ficou mais nítida a tentativa de interlocução de pessoas da CBA com o grupo opositor. No intervalo da audiência, membros da CBA e CNEC conversaram com pessoas dos grupos contrários, de forma amistosa, algo que não ocorrera anteriormente e não voltaria a se repetir.

Embora na audiência de Registro a plenária tenha sido suspensa pelo presidente da mesa até que fosse feito um acordo para que parte do movimento social deixasse os políticos favoráveis ao empreendimento fazer a fala de abertura do debate ${ }^{105}$, foi em Eldorado que a lógica da disputa em torno do licenciamento ambiental tornou-se explícita.

\footnotetext{
${ }^{105}$ Em Registro, devido a constantes interrupções do plenário às primeiras falas, a audiência foi suspensa e feito um acordo, mediado pelo bispo, a partir do qual as manifestações a respeito das falas só se dariam ao término das manifestações e não mais durante a exposição de algum dos participantes. $\mathrm{O}$ acordo preservou a fala de pessoas favoráveis ao empreendimento que tiveram seus posicionamentos acompanhados de críticas por parte dos grupos contrários a UHE.
} 


\subsection{1 É um Vale Rico - A audiência de Cerro Azul}

A audiência ocorreu no ginásio municipal que estava lotado. O público ocupou todas as dependências do ginásio - arquibancadas situadas na lateral do prédio, dispostas de frente a quadra com as cadeiras enfileiradas na quadra de frente à mesa e o telão utilizado pelo IBAMA e consultores da CNEC nas suas exposições.

O público da audiência foi eclético. Havia crianças, homens, mulheres e adolescentes. No auditório, as manifestações contrárias ao empreendimento eram mais visíveis através de faixas penduradas, bandeiras do MOAB - Movimento dos Atingidos por Barragens, e cartazes levantados em meio ao público.

Figura 26 - AAudiência em Cerro Azul foi um acontecimento na cidade. O ginásio estava cheio e a primeira plenária foi pequena mostra dos embates que ocorreriam principalmente nos debates de Eldorado e Registro.

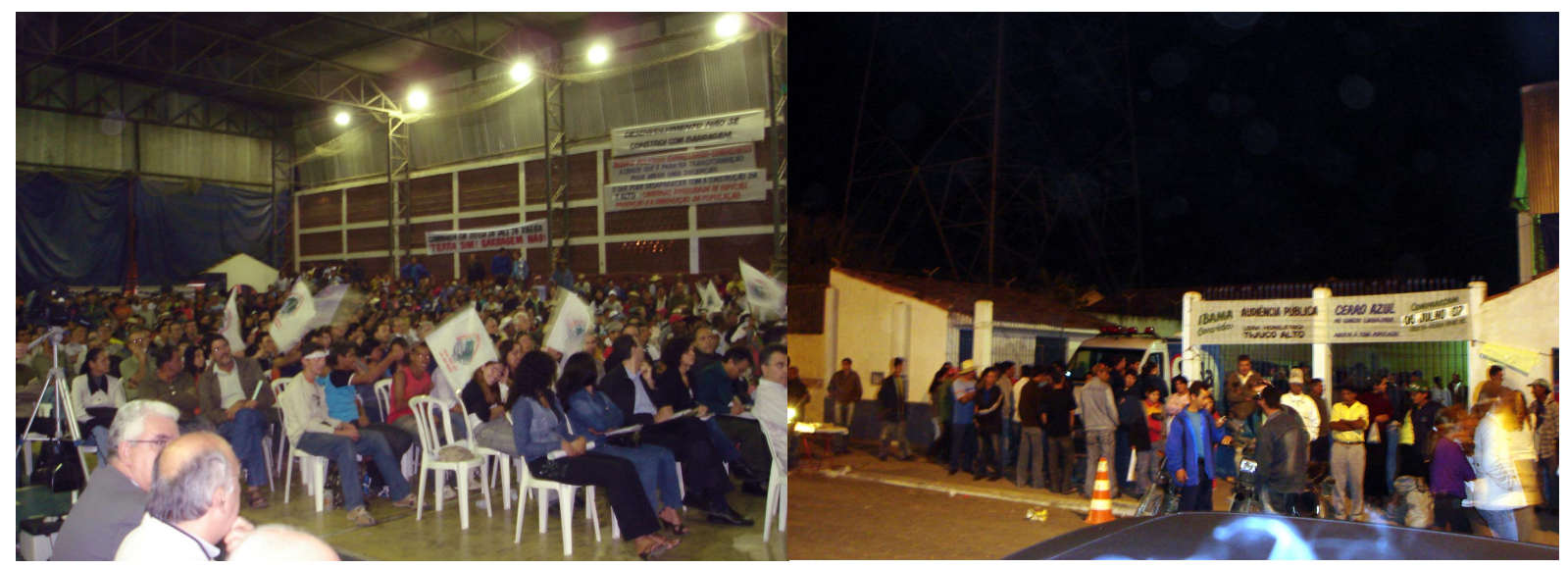

Fotos: Alexandre do Nascimento Souza - Cerro Azul - 06/07/07

Do lado de fora do ginásio, havia um clima de grande evento, muitos cidadãos na entrada, carro de pipoca, barraca de cocada, barraca de cachorro quente e até roletas encontradas em parques populares, além da polícia militar e de alguns ônibus estacionados nas imediações.

A CBA/CNEC destacou um funcionário da empresa de assessoria de imprensa contratada pela CBA que ficou logo na entrada do ginásio procurando identificar pessoas que pudessem ser de órgãos da imprensa. Ao entrar no ginásio fui abordado por esta pessoa que se identificou como Mário e anotou meu nome, telefone, e-mail e instituição. O mesmo repetira o gesto minutos antes com um trio de pesquisadores do CEBRAP.

A plenária de Cerro Azul foi uma espécie de esquentar de tambores dos embates entre o movimento social organizado e o grupo formado por empreendedor e consultores contratados. 
Ainda no início da sessão de questionamentos, quando o Sr. Adriano Briatore estava formulando sua questão, quando falava não concordar com o estigma de que o Vale do Ribeira era pobre, um grupo de 8 pessoas vestidas de preto e carregando um caixão como a encenar um funeral, atravessou a quadra, em meio às cadeiras e quando chegaram na frente da mesa no espaço que separava a mesma do público, começaram a retirar uma série de frutas do caixão em meio a palavras gritadas e toques de pandeiro e palmas: - "é um Vale rico”. Esta encenação durou alguns poucos minutos e depois Briatore voltou à sua fala. Logo depois, começaram a ecoar grito de tempo.

A sessão de perguntas e respostas foi se mostrando cansativa. O momento alto do debate foi quando um dos integrantes do $\mathrm{MOAB}$ questionou os defensores do empreendimento sobre a relação existente entre construção de hidrelétricas e melhora do IDH e citou como exemplo o município de Juquiá onde existem duas UHEs da própria CBA.

Ronaldo Crusco tentou responder a questão, mas o presidente da mesa não ficou satisfeito e solicitou que a consultora do meio sócio econômico viesse explicar a relação e a mesma, não sendo convincente, desgastou-se frente ao plenário.

\subsubsection{Torcida organizada em Ribeira}

O clima da audiência em Ribeira foi muito diferente do que ocorrera em Cerro Azul.

Ao contrário do município paranaense, onde faltavam faixas de apoio ao empreendimento e sobravam faixas contrárias, em Ribeira, as faixas de apoio ao empreendimento foram em maioria eminente e ocuparam todas as paredes do ginásio onde se realizou a audiência, assim como estiveram espalhadas pelas ruas do município, normalmente na frente dos estabelecimentos comerciais ${ }^{106}$.

Fora do ginásio, sobretudo no seu entorno, a maioria dos comerciantes exibiam na fachada de seus estabelecimentos comerciais, faixas de apoio à hidrelétrica.

A presença de cidadãos em Ribeira foi menor do que em Cerro Azul, embora, com o decorrer da

${ }^{106}$ Houve até um documento que foi protocolado por um dos participantes da plenária que acusava a CBA de ter mandado fazer as faixas e bandeiras, uma vez que todas tinham o mesmo padrão estético. Parte dessas faixas foram colocadas no ginásio onde foi realizada a plenária de Adrianópolis-PR, no dia seguinte. 
discussão, tenham chegado mais pessoas, com destaque para um grupo grande de mulheres e crianças que chegaram munidas de bandeiras declarando apoio ao empreendimento.

O grupo tinha duas mulheres que ficaram a orientar a manifestação das demais. A toda fala favorável à construção de Tijuco Alto balançavam as bandeiras - “TIJUCO ALTO JÁ”, gritavam e aplaudiam. As falas contrárias eram acompanhadas por vaias ${ }^{107}$.

\section{Figura 27 - Faixas Padronizadas de Apoio ao empreendimento e torcida organizada: mulheres e criança com bandeirinhas na mão}

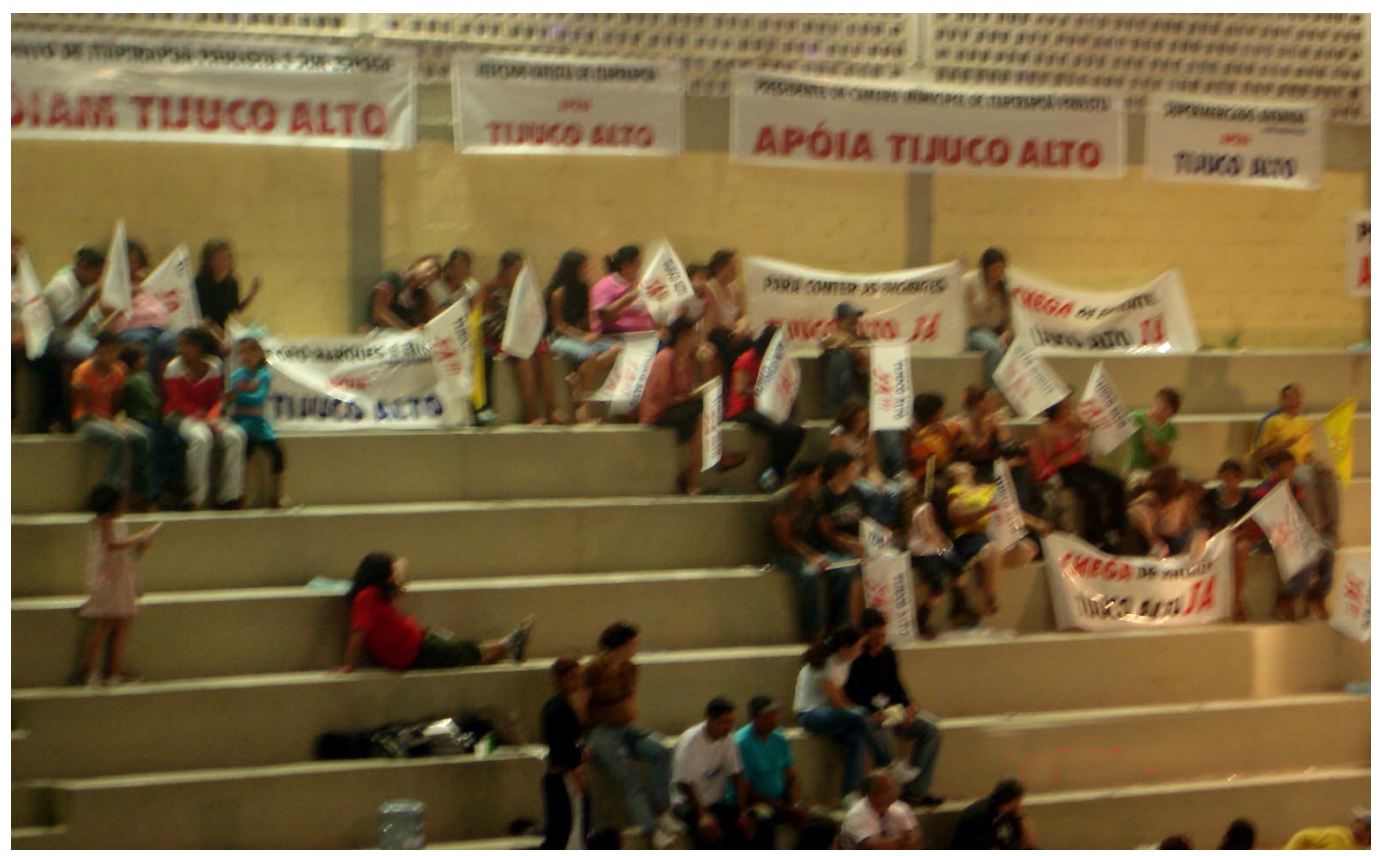

Foto: Alexandre do Nascimento Souza - Ribeira - 07/07/08

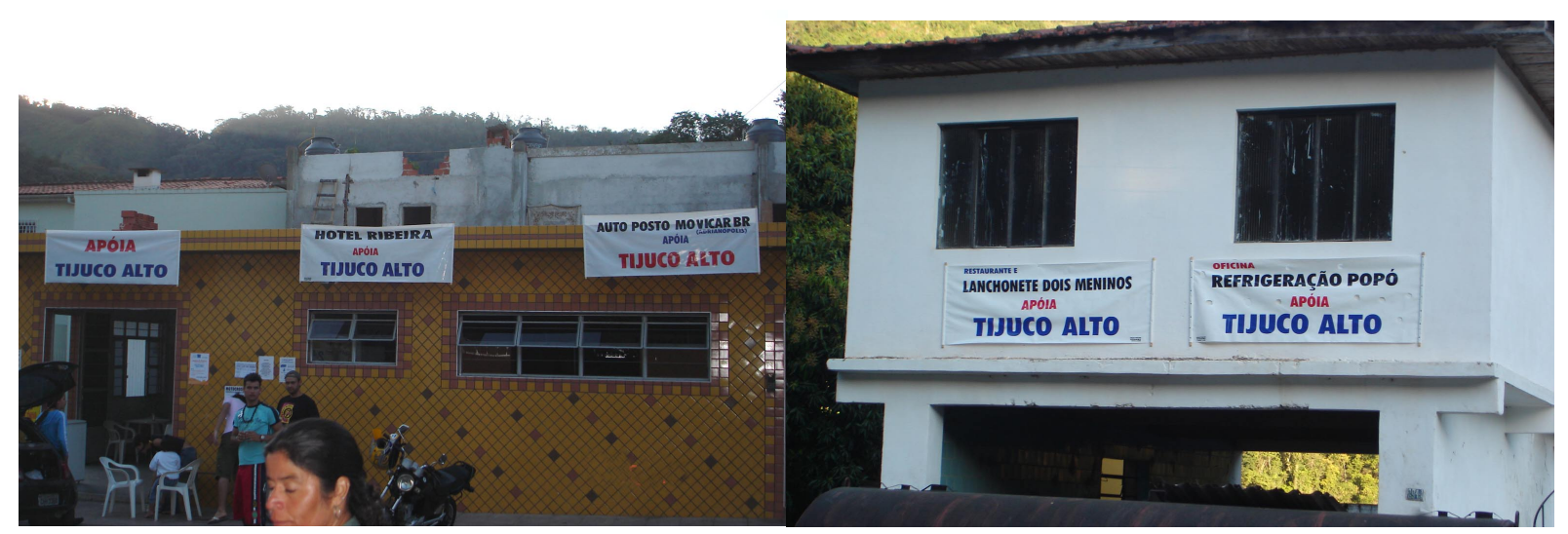

Fotos: Alexandre do Nascimento Souza - Ribeira - 07/07/07

\footnotetext{
${ }^{107}$ Exceção aconteceu quando da intervenção do prefeito do município durante os debates. Após longa fala de Jonas Batista, na qual leu um documento que expressava certa contrariedade em relação a UHE devido aos prejuízos causados ao município durante os 18 anos em que se arrasta o licenciamento; parte do grupo que ocupou as arquibancadas o aplaudiu. Talvez por engano tenham confundido o prefeito como favorável ou falou mais alto a liderança política de Jonas.
} 


\subsubsection{Tranquilidade do debate possibilitou um "footing" - A audiência de Adrianópolis}

O clima da audiência de Adrianópolis foi tão tranquilo que o Staff da CBA/CNEC chegou a circular pelo ginásio durante o intervalo e no transcorrer da audiência. Alguns até ficaram em lugares afastados do local onde o grupo ficou posicionado. Em Ribeira isso também ocorrera, havia dois integrantes do staff técnico que se deslocaram pelo plenário, inclusive quando possível conversaram com as pessoas presentes. Mas em Adrianópolis mais pessoas do grupo passearam pelo plenário e o diretor de logística da CBA, José Rodrigues, até se deslocou da mesa e tentou criar interlocução com uma das pessoas do Coletivo Educador do Lagamar, um grupo bastante atuante durante as audiências.

\subsubsection{Um "Circo" de casa cheia - A Audiência de Eldorado}

Durante as três primeiras audiências públicas havia um clima no ar e em alguns momentos também nas falas ${ }^{108}$ que prometia um duro embate entre CNEC/CBA e grupos contrários ao empreendimento na quarta audiência, realizada em Eldorado. De fato, o clima em Eldorado foi de muita pressão social ${ }^{109}$. Além da forte presença das Comunidades Quilombolas, especificamente o Coletivo Educador do Lagamar que durante as outras três audiências contou com aproximadamente 8 pessoas, em Eldorado levou muito mais gente, na verdade uma espécie de Charanga com instrumentos de percussão e seus integrantes com narizes pintados de vermelho, a imitar palhaços.

Em um dado momento, o presidente da mesa ameaçou inclusive que poderia solicitar a retirada dos instrumentos do plenário uma vez que a cada intervenção favorável ao empreendimento os instrumentos eram tocados, acompanhados de vaias e apitasso.

As paredes do ginásio estavam forradas com faixas de apoio e também contrárias ao empreendimento.

\footnotetext{
${ }^{108}$ O ISA prometeu na audiência no município de Ribeira que iria protocolar na audiência de Eldorado um estudo feito sobre o EIA de Tijuco Alto elaborado pelo Prof. Dr. Oswaldo Sevá, professor do Departamento de Energia da Faculdade de Engenharia Mecânica / Unicamp.

${ }^{109}$ Em Ribeira e Adrianópolis soube que em Eldorado, antes da audiência haveria uma reunião dos grupos contrários a UHE, no entanto não consegui saber se de fato ocorreu. De qualquer maneira, a simples disposição para uma reunião preparatória da atuação já demonstra o grau de disputa presente ao evento.
} 
Figura 28 - Faixas espalhadas por todo o plenário exibiam posição favorável e contrária ao empreendimento

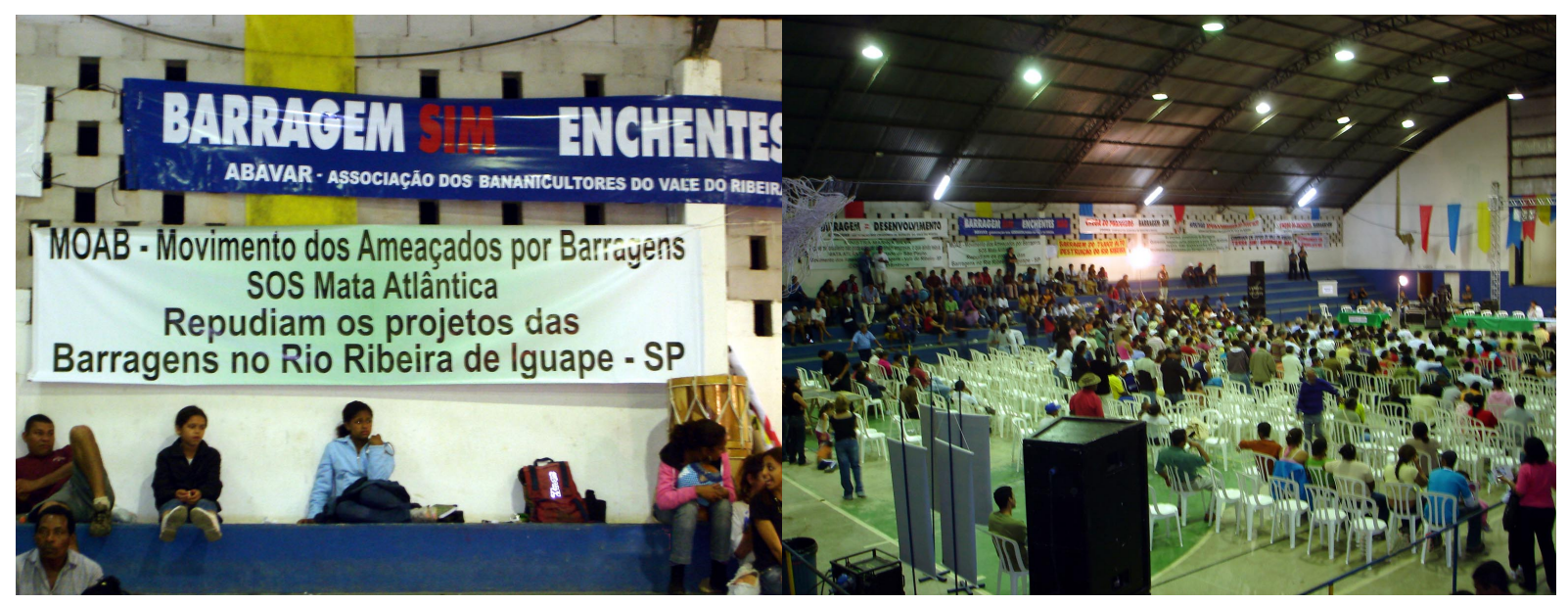

Fotos: Alexandre do Nascimento Souza - Eldorado - 09/07/08

O tom do debate foi dado logo no início dos trabalhos. Quando convidado a participar da mesa de abertura e fazer uma fala protocolar de saudação da plenária, o Sr. José Rodrigues da Silva, representante da comunidade quilombola do Ivaporunduva, cumprimentou toda a mesa e disse que em nenhum momento os quilombolas foram convidados a participar dos estudos feitos pela CBA/CNEC. Disse que o IBAMA e a CBA limitaram-se às vistorias e em nenhum momento procuraram as comunidades quilombolas.

Em função disso, o representante dos quilombolas considerava antiético e injusto que fossem convidados a participar da mesa de abertura e que estavam sendo chamados ali para justificar o empreendimento. "O pessoal do IBAMA e da CBA andaram pelo Vale de carro e avião e as comunidades de fora". Pediu desculpas e retirou-se da mesa por não se sentir bem ali.

A fala do representante dos quilombolas foi todo o tempo acompanhada de aplausos e gritos de apoio. A CBA/CNEC quis esclarecer algum aspecto da fala do líder quilombola, mas o Sr. Muchagata, presidente da plenária, não considerou necessário ${ }^{110}$.

\footnotetext{
${ }^{110}$ Esse fato é bastante ilustrativo da maneira como o Sr. Muchagata conduziu os trabalhos, pois, ao não conceder o direito da CBA/CNEC explicar-se na verdade evitou que a plenária pegasse fogo antes mesmo de iniciar os debates. Ao consultar os volumes do processo encontrei comunicados da CBA ao IBAMA no qual informava que as comunidades se negavam a receber seus técnicos, provavelmente era isso que iam dizer caso lhe fosse concedido o direito ao esclarecimento. A postura dos grupos quilombolas em não receber os técnico da CBA/CNEC deveu-se ao fato de o IBAMA ter-lhes negado o direito de discutir a definição do Termo de Referência. Em diversos comunicados, o MOAB informou que queria dialogar com o IBAMA e não com a CBA/CNEC.
} 


\subsubsection{Garantir a fala de todos e tolerância com posições diferentes -A Fala do IBAMA e do MME.}

Em Eldorado, antes de iniciar a apresentação do IBAMA, Walter Muchagata, falou sobre a importância do licenciamento, lembrou que a procuradora Maria Luiza Grabner ${ }^{111}$ tinha razão ao dizer que não era favor a realização das audiências.

Por mais que os estudos sejam bem feitos e que os técnicos do IBAMA tenham competência, nas audiências, podem surgir novos atos, por isso é importante também que as pessoas conheçam o projeto, saibam o que está sendo proposto para que possam discutir.

Muchagata finalizou a introdução a sua fala lembrando a importância de se respeitar as falas e que o IBAMA estava ali para garantir o posicionamento de todos.

A apresentação do representante do IBAMA esteve menos focada nas lâminas de slide, como nas audiências anteriores e procurou ser mais didático no sentido de deixar claro garantias e seguranças de que o processo de licenciamento estava sendo regido por procedimentos técnicos e que garantiam a participação e posicionamento daqueles que fossem contrários. Embora tranqüilo na forma de se expressar, a fala do presidente da audiência foi endereçada ao movimento social presente e as palavras ditas foram pensadas uma a uma.

No término da sua fala, Walter Muchagata chamou atenção para a importância das audiências públicas e por isso a necessidade que o debate fosse garantido.

A Sra. Márcia Camargo, representante do Ministério de Minas e Energia ${ }^{112}$, que não havia falado nas audiências anteriores foi chamada ao microfone. A servidora saudou os participantes em nome do Executivo federal e que a participação de todos com a capacidade de escutar e de dialogar é o meio para o esclarecimento das questões que levariam a uma decisão pública.

A coordenadora-geral de monitoramento dos recursos hídricos do MME chamou atenção para o fato

\footnotetext{
${ }^{111}$ A procuradora falou antes do presidente da plenária e afirmou ser fundamental a participação das pessoas que estavam ali e que deveriam aproveitar o momento das audiências que não eram um favor e sim um direito.

${ }^{112}$ Desde Cerro Azul as audiências foram acompanhadas por um representante do MME. Nas duas primeiras audiências esteve presente a servidora Mônica Arruda e a partir de Adrianópolis a própria Márcia Camargo. Mas até aquele momento nenhuma delas teria participado das falas inaugurais.
} 
de que a decisão a respeito do empreendimento ser conduzida por leis que procuram harmonizar o direito das comunidades, o desenvolvimento social e a geração de energia elétrica, fundamentais ao nosso país. Agradeceu a todos e sugeriu tolerância para se escutar as opiniões favoráveis e contrárias.

A fala da representante do MME não foi interrompida e ao término foi acompanhada de poucas palmas vindo do canto onde se postara o staff da CBA/CNEC.

\subsubsection{Novos atores e tropas reforçadas ${ }^{113}$}

A audiência em Eldorado teve novos atores sociais que ainda não tinham aparecido e todos os grupos que estiveram a acompanhar as audiências anteriores estiveram reforçados, inclusive o Staff CBA/ CNEC. Além dos grupos que acompanharam as outras audiências houve novas pessoas de São Paulo (e) que militam contrariamente à instalação da UHE.

Foi clara a participação de muitas pessoas oriundas da Universidade e ou ligadas a ONGs. Muitas dessas pessoas são pesquisadores e têm contato com as comunidades quilombolas, outras são da região e estudam e ou trabalham fora e vieram simplesmente "para ver no que ia dar"114.

Esteve presente uma grande quantidade de políticos da região - prefeitos, vereadores e vice-prefeitos de inúmeros municípios de toda a parte paulista do Vale do Ribeira, inclusive do município de Ribeira, onde já houvera Audiência Pública. O presidente e o secretário executivo do Comitê de Bacia Hidrográfica do Rio Ribeira do Iguape também estiveram presentes.

O Ministério Público Federal teve os reforços da Procuradora Maria Luíza Grabner ${ }^{115}$ e do procurador federal em Santos, Antônio José Molina Baloier.

O advogado do Instituto Socioambiental, Raul Vale, que estava em Cerro Azul e Ribeira e se mexeu

\footnotetext{
${ }^{113}$ Boa parte das pessoas que surgiram como protagonistas do debate em Eldorado, também participaram da plenária de Registro.

${ }^{114}$ Fala de uma cidadã de Jacupiranga que disse que estava ali para saber finalmente se ia ou não sair a UHE, que ninguém agüentava mais tanto discussão e tanta falta de decisão.

${ }^{115}$ A procuradora Maria Luíza Grabner foi quem em nome do MPF atuou de forma decisiva durante o primeiro licenciamento para que o licenciamento fosse feito junto ao IBAMA e não nas duas secretarias estaduais de São Paulo e Paraná como tentou a CBA.
} 
com maior desenvoltura, parecia em casa, uma vez que a sede do ISA no Vale do Ribeira fica em Eldorado, motivo pelo qual também havia outras pessoas do ISA na plenária.

A presença maior de atores de classe média, a disposição dos movimentos organizados que vieram em maior número e melhor instrumentalizados, a presença de lideranças políticas e econômicas da região e pesquisadores em maior número fizeram da audiência de Eldorado o momento do grande encontro, onde se deu a maior batalha do ciclo de audiências.

A grande mobilização na primeira plenária realizada fora do Alto Ribeira, demonstra claramente a influência de São Paulo na mobilização e movimentação em relação à Tijuco Alto.

Pois vieram, além das caras novas no plenário, provenientes sobre tudo de São Paulo, houve também maior presença das comunidades quilombolas e lideranças dos movimentos sociais da região do Vale do Ribeira que em Eldorado se fizeram presentes em peso.

O que é de se perguntar é o porquê dessa força não ter se deslocado até Ribeira, Adrianópolis e Cerro azul? As audiências deixaram claro que toda movimentação política que ocorre no Vale do Ribeira em São Paulo não vai até o Alto Ribeira que vive uma outra situação em relação a tudo, inclusive projetos e programas sociais realizados por ONGs da região ou de fora.

Em poucas palavras: o clima, a presença e participação manifestos já nos primeiros momentos da audiência fizeram da plenária de Eldorado a mais prestigiada e também com clima de disputa mais acirrado.

O clima geral da plenária foi semelhante ao da primeira audiência: grande participação local, forte presença dos movimentos sociais e autoridades políticas, só que com intensidade bem maior. Houve em Eldorado o mesmo clima de tensão pairando no ar, em torno da disputa entre favoráveis e contrários ao empreendimento, como ocorrera em Cerro Azul. Como no município paranaense, a plenária parecia mobilizar a cidade, se constituindo ela mesma em um grande evento no município.

O plenário foi majoritariamente contrário à instalação da UHE. Um grupo de trabalhadores rurais da região que recebeu algumas camisas favoráveis ao empreendimento, no estacionamento, do lado de fora do ginásio, pouco ficaram no plenário, sentaram no fundo e não se manifestaram. Entraram e saíram calados e sem ser notados. 
Figura 29 - Grupo de agricultores recebeu camisa manifestando apoio ao empreendimento: "Barragens Sim, Enchente Não". No entanto, pouco permaneceram no ginásio

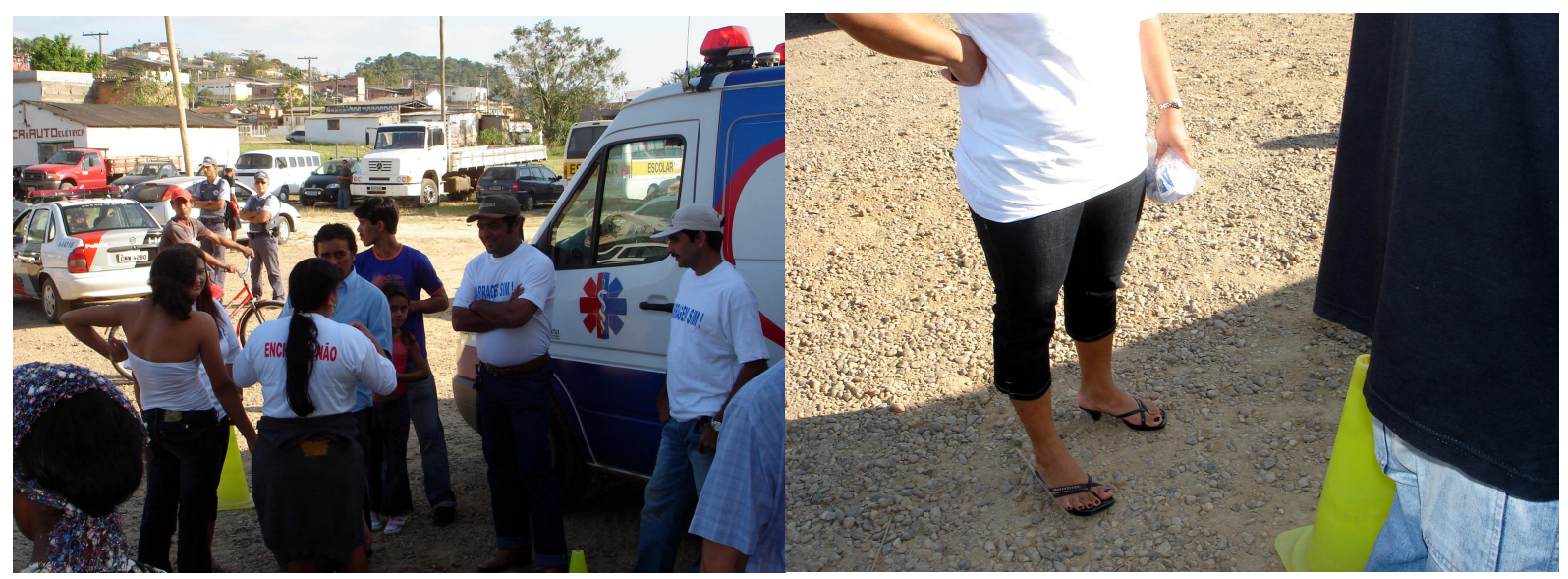

Fotos: Alexandre do Nascimento Souza - Eldorado - 09/07/08

Além dos seguranças da $\mathrm{CBA}^{116}$, na audiência de eldorado uma empresa de segurança foi contratada. Seguranças fardados e com walk talks na mão, posicionados nas entradas do ginásio e nas fileiras de cima das arquibancadas permaneceram durante todo o debate atentos à movimentação.

A simples contratação do serviço de segurança fez transparecer que os organizadores das audiências, sobretudo a $\mathrm{CBA}^{117}$, imaginaram que havia possibilidade da emergência de conflitos inter pessoais e ou possível risco ao bom andamento da discussão em Eldorado, pois nas três outras audiências, ao menos publicamente, não houve a presença de seguranças, a não ser o que já relatamos anteriormente em relação a um grupo de homens que acompanharam o staff CBA/CNEC e que normalmente estiveram posicionados sempre próximos ao local onde ficava o grupo de consultores da $\mathrm{CNEC}$, dirigentes e funcionários da CBA.

Como nas demais audiências, à medida que o tempo avançava, o plenário se esvaziava. Em combate, os mesmos atores das plenárias anteriores: a mesa composta pelo presidente e secretária executiva da audiência, staff da CBA/CNEC, lideranças do MOAB, a ambientalista Laura de Jesus, o Coletivo Educador do Lagamar e alguns quilombolas. Cenário idêntico ao das outras plenárias, quando apenas esses mesmos atores permaneceram a disputar suas posições. Na medida que o plenário se esvaziava, só ficaram as pessoas inscritas dos grupos organizados contrários ao empreendimento.

\footnotetext{
${ }^{116} \mathrm{O}$ staff da CBA/CNEC tinha um grupo de seguranças muito discretos que estava sempre próximo de onde ficavam sentados.

${ }^{117}$ De acordo com a legislação cabe ao empreendedor a organização e custos das audiências.
} 
Do ponto de vista do posicionamento dos atores envolvidos, os consultores da CNEC capitaneados por Ronaldo Crusco tiveram uma postura mais agressiva na forma de se expressar, inclusive, fizeram algo inédito até aquele momento: protocolaram um documento junto à mesa; expediente muito utilizado pelos contrários à instalação do empreendimento durante as outras três audiências.

O consultor da CNEC e geólogo da UFSCAR, Irineu, chegou a falar que a preocupação deveria ser não jogar esgoto no Rio e não a reiterada preocupação, manifesta em inúmeras perguntas no correr das audiências, em torno da contaminação da água devido a presença de chumbo.

Do outro lado, o movimento contrário ao empreendimento assumiu discurso que apontava a todo o momento a falta de credibilidade das respostas da CBA/CNEC uma vez que, a cada esclarecimento, os argumentos se repetiam em relação ao que já fora dito em Eldorado e nas demais audiências.

Na audiência de Eldorado ficou escancarado algo que já se anunciava nas outras audiências: a total falta de disposição de cada uma das partes envolvidas no processo de licenciamento do aproveitamento Tijuco Alto em ouvir o outro. Na verdade, por tudo que já foi dito a respeito da audiência de Eldorado, ficou claro que ali aconteceu não um debate onde as partes em discordância buscaram um espaço de entendimento e negociação dos seus conflitos e acomodação dos diversos interesses. Mas apenas mais um round de uma batalha que se arrasta há quase 20 anos.

Não houve propriamente uma discussão a respeito das características do projeto, sua localização ou da característica dos programas compensatórios ${ }^{118}$. Mas de maneira simplista e até subversiva em relação à legislação, a discussão se deu, de fato, sobre a instalação ou não da hidrelétrica. Foi esse o tema que orientou o comportamento do empreendedor e da consultoria contratada, de um lado; e das populações atingidas, ONGs e demais entidades do movimento social, do outro.

\subsubsection{O balde entornou - A Audiência de Registro}

Essa expressão popular é a que melhor caracteriza o que aconteceu na audiência pública de Registro.

\footnotetext{
${ }^{118}$ Em relação às características dos programas compensatórios, a legislação faculta ao empreendedor apenas apresentá-los enquanto intenção sem precisar detalhá-los na fase da Licença Prévia. O que por si só já cria um entrave à discussão, à medida que os possíveis prejudicados pelos empreendimentos não têm garantia alguma de como serão executados os programas.
} 
Embora a plenária de Eldorado tenha sido o momento em que o licenciamento de Tijuco Alto se desnudou por completo, em Registro, “o balde entornou”. Toda a tensão, a dita e a não dita em torno do licenciamento e dos atores sociais em disputa eclodiu na última audiência do ciclo.

Talvez por ser a última audiência, talvez pela exaustão causada pelo intenso processo vivenciado pelos principais protagonistas dos debates há cinco dias consecutivos, talvez pelo apertado do espaço frente à quantidade de pessoas ou um pouco de tudo isso, contribuiu para que o quinto e último debate tenha corrido risco efetivo de quase não ocorrer, pois ainda na mesa de abertura, o presidente da plenária, Walter Muchagata, até aquele momento, calmo e ponderado, praticamente um mediador, em tom muito acima do que utilizara nas duas outras audiências, suspendeu o debate e vaticinou que sem um acordo os trabalhos estariam encerrados.

Ainda na composição da mesa, logo no início dos trabalhos, quando o prefeito de Registro, Clóvis Vieira foi chamado à mesa, o plenário começou a vaiar e tocar. Muchagata logo se apressou a pedir que se mantivesse o clima democrático e que a palavra de cada um deveria ser respeitada.

Afirmou que o papel do IBAMA ali era o de ouvir a sociedade e que se o debate ficasse prejudicado, a própria audiência perderia seu sentido.

Se hoje a sociedade tem um instrumento que faz parte da democracia e que é uma conquista da sociedade, que haja um espaço para o questionamento, debate e enriquecimento do processo quando se trata da possibilidade da implantação de uma obra de infra-estrutura. Para o IBAMA interessa que o espaço seja plenamente exercido pela sociedade.

Por essa razão, o órgão solicitava da plenária que evitasse atitudes de desrespeito a qualquer participante da audiência pública, fosse na instalação da mesa ou quando do início dos debates.

Durante as falas do representante da CBA e da CNEC, do prefeito de Registro e principalmente do Deputado Samuel Moreira o plenário se manifestou contrariamente. Depois de reiteradas solicitações por parte do presidente da mesa para que as falas fossem respeitadas, o servidor do IBAMA suspendeu a audiência e convocou as lideranças do MOAB, ISA, SOS Mata Atlântica, Igreja Católica, MME e CBA para que pudessem tentar construir um acordo que garantisse a continuidade da audiência. 


\section{Figura 30 - Plenário se manifestou contrário as falas de apoio diversas vezes durante a abertura dos trabalhos. Até que a audiência foi suspensa.}

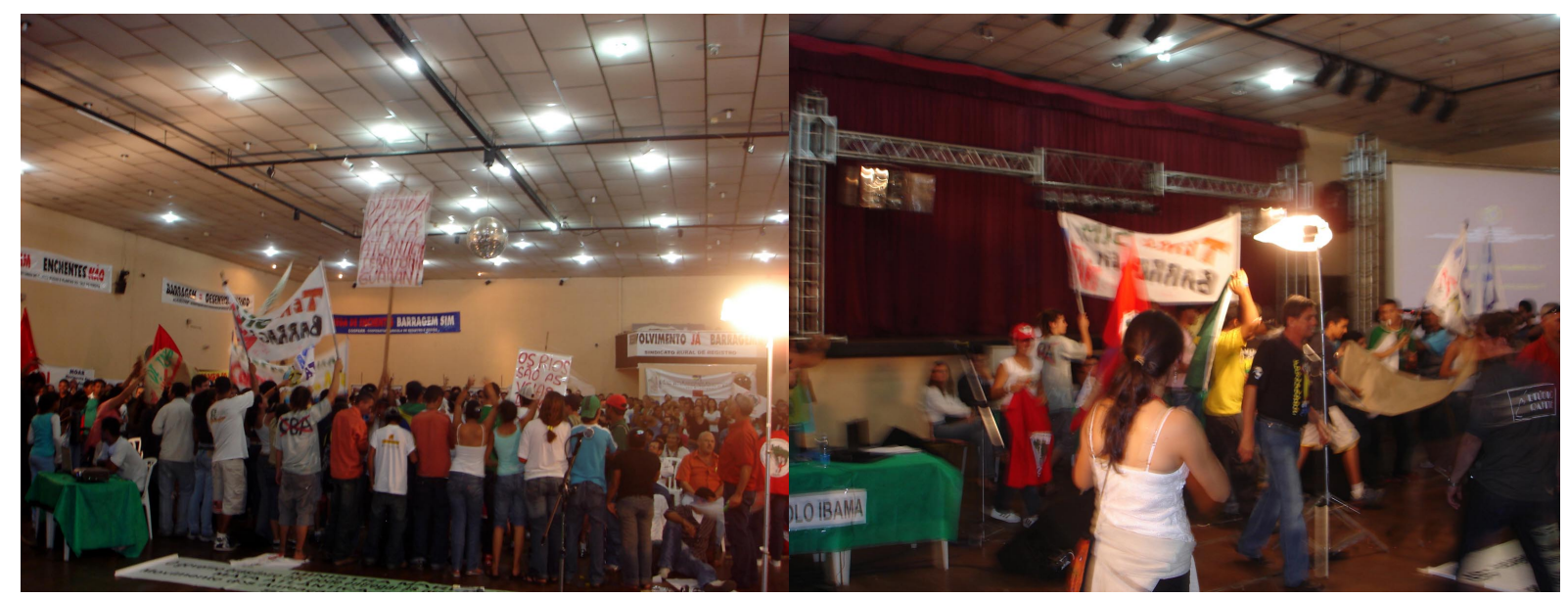

Fotos: Alexandre do Nascimento Souza - Registro - 10/09/07

Nesse momento se generalizaram vários focos de discussão no plenário. Um grupo formado pelo presidente da mesa, SOS MataAtlântica, ISA ${ }^{119}$, Bispo de Registro e MME, construiu o acordo a partir do qual não haveria manifestação durante as falas, mas após a intervenção de cada um, todos poderiam se expressar.

Um outro grupo se formou composto por lideranças do MOAB, o deputado Samuel e o prefeito de Registro. Nessa roda havia uma discussão em que o responsável pelo acirramento dos ânimos teria sido o prefeito de Registro, Clóvis Vieira, que havia dito a um quilombola no dia anterior algo a respeito daquela audiência ${ }^{120}$ e que isso teria acirrado os ânimos. O prefeito se retratou e as desculpas foram aceitas ali mesmo no calor discussão.

Na verdade, quando a audiência foi suspensa e os focos de discussão se generalizaram, ficou claro que naquele momento havia o extravasar de todas as tensões que se acumularam durante o ciclo de audiências, sobretudo no dia anterior, na audiência de Eldorado, quando todos foram preparados para uma grande batalha que durou quase 10 horas.

Em Registro, a audiência foi realizada no auditório do Clube KKK, espaço bem menor do que os ginásios esportivos onde ocorreram as plenárias anteriores.

\footnotetext{
${ }^{119}$ O Instituto Sócio ambiental só acompanhou a movimentação e não se pronuncio nem na hora do conflito e nem em momento algum da audiência em Registro.

${ }^{120}$ Não consegui descobrir o que foi dito pelo prefeito a uma das lideranças quilombola. O que ficou claro pelo diálogo é que teria sido uma espécie de ameaça do tipo, amanhã vocês verão na audiência que vamos aprovar o projeto ou coisa do tipo.
} 
No alto das paredes só tinham faixas de apoio ao empreendimento. Pois o auditório não tinha onde se pendurar as faixas como nos ginásios. As faixas colocadas de apoio foram colocadas antes da audiência e envolveram certa complexidade se comparada com as condições dos ginásios. Na verdade foram grampeadas na parede e a colocação exigiu escada.

Figura 31 - Só havia faixas favoráveis ao empreendimento no auditório da audiência de Registro. Colocá-las e retirá-las não teve a mesma facilidade das plenárias anteriores

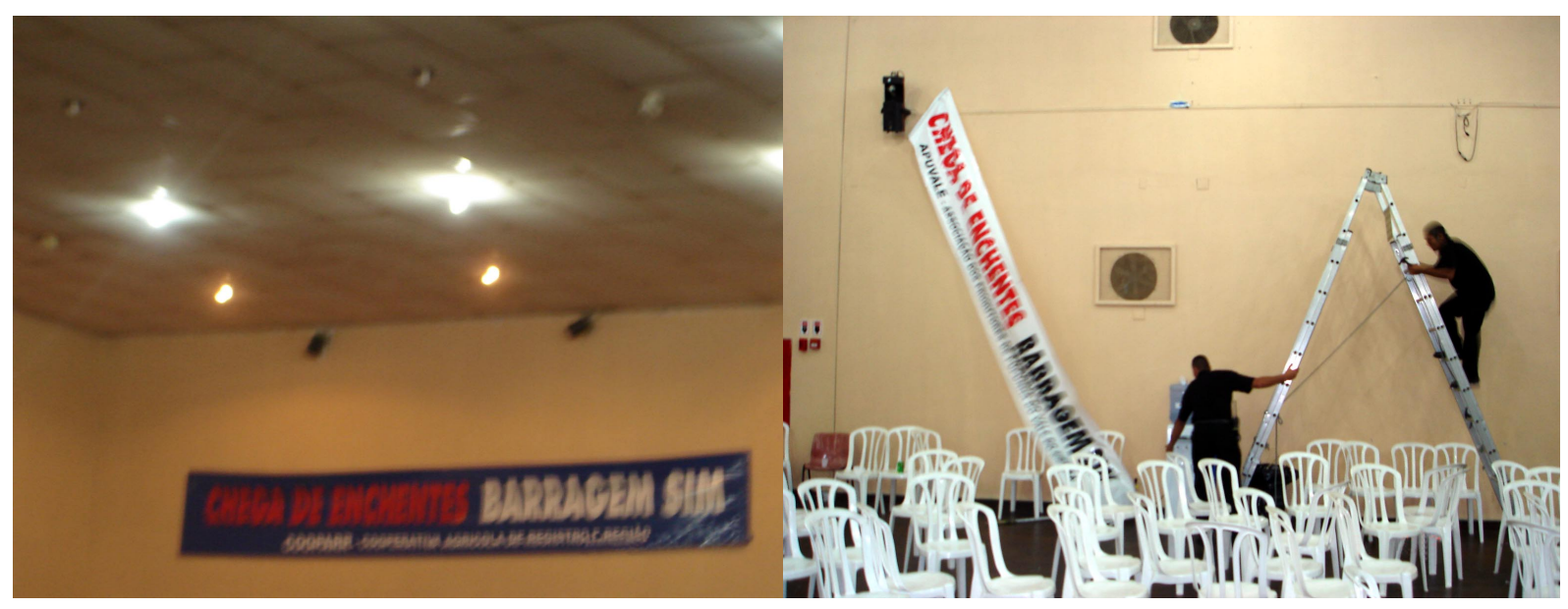

Fotos: Alexandre do Nascimento Souza - Registro - 10/09/07

Muito provavelmente, quando o espaço foi preparado para receber a audiência, as faixas foram colocadas, até porque eram semelhantes a algumas faixas penduradas no ginásio de Eldorado.

Esse fato não deixa de ser uma demonstração clara de que o controle das audiências nas mãos do empreendedor, nesse caso, lhe favoreceu. Pois, teve acesso ao espaço com antecedência e conhecia as condições do local a ponto de criar soluções que lhe permitiram que só tivessem faixas de apoio ao empreendimento.

A audiência de Registro acabou depois de 4 horas da manhã, nove horas depois de iniciado o debate. 


\section{CONCLUSÃO}

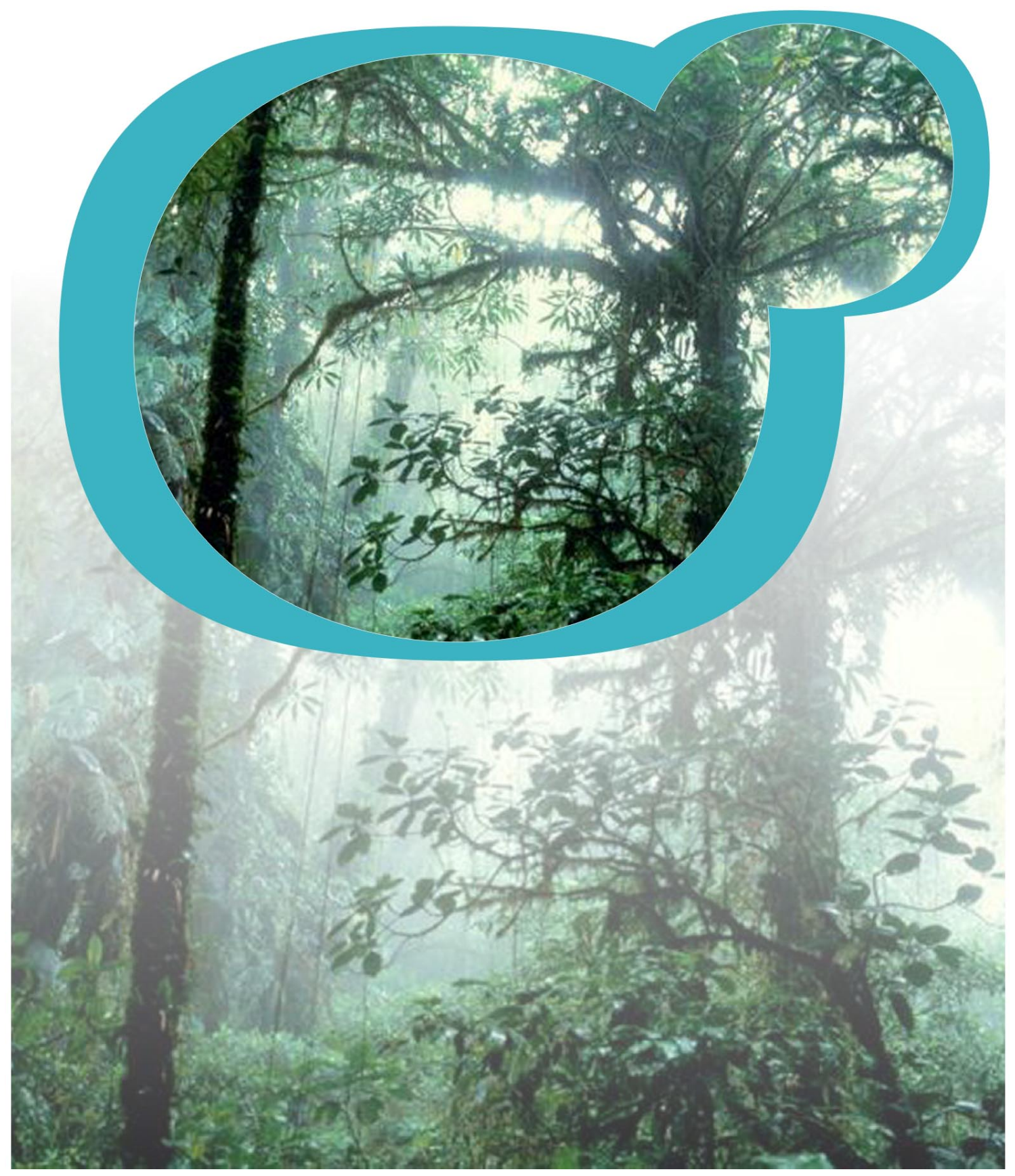




\section{Conclusão}

O licenciamento ambiental no Brasil, em que pese todas as críticas, insatisfações, e a percepção de que seja um obstáculo a ser superado, ou um instrumento falho e que precisa ser melhorado, não há dúvidas de que tem sido um importante instrumento que tem contribuído com a melhoria da qualidade socioambiental dos empreendimentos hidrelétricos.

Sob o ponto de vista da "Teoria da Modernização Ecológica" as conclusões desta pesquisa no seu conjunto guardam algumas ambigüidades ao sabor do estado atual do instrumento analisado nos três anos desta pesquisa.

Como argumentamos no terceiro capítulo, o licenciamento ambiental é uma iniciativa em total sintonia com a modernização ecológica, uma vez que busca equacionar a necessidade da sociedade de produzir sem comprometer os serviços ambientais para as gerações futuras.

O instrumento previsto pela PNMA e confirmado na constituição de 1988 prescinde da utilização da ciência e tecnologia enquanto instrumental destinado a conceber projetos menos danosos ao meio ambiente e mais eficientes do ponto de vista produtivo. No setor de geração de energia hidrelétrica as usinas do complexo do Rio Madeira são um claro exemplo de como a ciência e tecnologia estão sendo incorporadas aos projetos de maneira a torná-los menos onerosos ao ambiente ${ }^{121}$.

A mudança do projeto inicial proposto para as duas UHEs inclui outro tipo de turbina, e mudança no arranjo produtivo do empreendimento que serão praticamente a fio d'água. Essa característica do licenciamento ambiental dialoga com a primeira heurística da MEque argumenta que a ciência e a tecnologia deixam de ser vilões da degradação ambiental e passam a ser vistas como parceiras ao contribuírem com a busca da equação que preserva o ambiente e garante o crescimento e desenvolvimento do sistema produtivo.

\footnotetext{
${ }^{121}$ Uma discussão que não é objeto desta dissertação, mas ajuda nossa reflexão é a percepção de que o planejamento do setor elétrico vem sendo feito sob uma ótica diferente da que sempre vigorou, de máximo aproveitamento do uso do potencial hidrelétrico. O Plano Decenal de Expansão do setor elétrico 2008-2017 prevê mais hidrelétricas a fio d'água e mais UTEs que irão atuar em consórcio com UHEs, uma vez que estas terão suas operações limitadas aos períodos de cheias dos rios. Do ponto de vista ambiental, essa opção abre uma grande discussão a respeito dos impactos causados pelo aumento das emissões de gases do efeito estufa e a qual opção seria mais conveniente: aumentar emissão de gases ou manter opção por hidrelétricas com grandes reservatórios. Para esta pesquisa o importante é perceber que o setor elétrico, cônscio das dificuldades político-ambientais para utilização do potencial hidrelétrico da região norte, tem optado por projetos com menor impacto ambiental, uma vez que não prevêem reservatório.
} 
O licenciamento ambiental pressupõe também a presença de outros atores no processo decisório, ou seja, ainda que o Estado continue a ter importância e papel importantes na tomada de decisão, partilha com outros atores a construção da tomada de decisão quando exige estudos técnicos sobre o projeto, e estimula participação social a partir das audiências ${ }^{122}$. Essas iniciativas trazem naturalmente novos atores para o processo político de tomada de decisões.

A partir de 2004, o Estado brasileiro teve uma série de iniciativas afinadas com a modernização ecológica na medida em que construiu uma série de diálogos com os mais variados setores econômicos, políticos e sociais relacionados ao debate do licenciamento em busca de construir novos consensos que pudessem produzir melhorias na aplicação do instrumento. A participação dos demais atores no processo de construção de políticas ambientais, e tomada de decisão, a respeito destas questões guardam sintonia com a heurística que aponta que o Estado abdica de uma posição de comando e controle e busca construir processos mais horizontalizados.

Do ponto de vista da heurística da modernização que apresenta as novas exigências de mercado como indutoras de práticas ambientais que preservem o ambiente ou que os utilizem de maneira a não comprometer a utilização das futuras gerações, apresentamos duas iniciativas do setor financeiro, voltadas ao desenvolvimento da infra-estrutura, em total sintonia com essa afirmativa, mas que ainda assim carecem de efetividade e aperfeiçoamento sistêmico.

As iniciativas "Princípios do Equador" e "Protocolo de Intenções pela Responsabilidade Socioambiental" são novas e ainda não tiveram tempo para produzir mudanças sistêmicas. O financiamento da UHE Jirau, após a proposta de outra localização para o eixo da barragem é bem indicativo do quão carentes de efetividade são os instrumentos, em que pese a positividade dessas iniciativa.

As instituições financeiras procuradas pelo consórcio vencedor para financiar o empreendimento informaram que só tomariam a decisão após o parecer de uma consultoria independente que analisaria o empreendimento com a nova localização à luz do documento "Princípios do Equador” (WIZIACK, J. \& BRITO, 2008).

\footnotetext{
${ }^{122}$ No correr do texto demos voz à posição dos diversos atores e nós mesmos apontamos fragilidades do instrumento que se corrigidas tendem a tornar o sistema mais eficiente. Em que pese estas fragilidades, estamos afirmando que o próprio instrumento contém elementos de modernização ecológica.
} 
Em fevereiro de 2009, o BNDES, uma das instituições signatárias do "Protocolo de Intenções pela Responsabilidade Social" destinou financiamento recorde ao empreendimento de R \$ 7,2 bilhões sem nenhuma menção à conveniência ambiental do empreendimento. O que ficou claro é que o banco de desenvolvimento garantiu o financiamento porque as UHEs do complexo do Madeira são fundamentais para que não corramos risco de apagão nos próximos anos.

Há um outro aspecto que não discutimos a fundo, mas que dialoga com essa heurística que é o Índice de Responsabilidade Social - ISE da Bovespa e do qual inúmeras empresas do setor elétrico fazem parte.

O ISE ${ }^{123}$ é uma iniciativa da Bovespa que busca valorizar as empresas a partir de critérios ambientais, sociais e econômico-financeiros. Édestinado as 150 empresas que mais têm suas ações negociadas na bolsa.

As duas outras heurísticas da modernização ecológica, de fato, encontram pouca correspondência no sistema de licenciamento ambiental no Brasil: "mudança na posição, função e ideologia dos movimentos sociais" e "mudança das práticas discursivas e novas ideologias".

Existem mudanças em curso e o Estado brasileiro, ao estabelecer agendas de diálogo com os diversos interesses que gravitam em torno do licenciamento, dá contribuição substantiva nessa direção, até porque provocou o pronunciamento público de diversos atores que no processo de diálogo explicitaram suas agendas, algo já apresentado e discutido nesse texto.

No entanto, as mudanças culturais, ou seja, a mudança na percepção dos atores a respeito do seu agir e o agir dos demais e de como os atores podem produzir mudanças em seu agir que façam o sistema de licenciamento avançar parece um tanto quanto longe ${ }^{124}$.

Do ponto de vista da ME a mudança cultural tem importante papel na medida em que provoca mudanças de comportamento. Ao falar das três fases do desenvolvimento da teoria, Mol (2001) afirma que

\footnotetext{
${ }^{123}$ Além do ISE, empresas em número crescente têm buscado, por iniciativa própria, associar-se aos princípios do Global Compact, uma iniciativa da ONU surgida no Fórum Econômico Mundial em 1999. Os princípios apresentados pelo organismo internacional têm preocupações com questões ligadas aos direitos humanos, meio ambiente, trabalho e de ética empresarial, entre outros. Em fevereiro de 2009, a Hidrelétrica de Itaipú distribui comunicado no qual informou que estava aderindo ao Global Compact. www.canalenergia.com.br - "Itaipú adere ao Pacto Global da Onu".

${ }^{124} \mathrm{Na}$ entrevista que me concedeu, o diretor de planejamento da ABDIB, Giancarlo Gerli, afirmou que a principal mudança que precisa haver no sistema de licenciamento, é a mudança cultural de todos os agentes em relação ao instrumento. Esse processo deveria ser estimulado e mediado pelo Estado, de acordo com a visão de Giancarlo.
} 
uma das características da segunda fase foi: "dar mais peso às dinâmicas cultural e institucional e ao papel dos seres humanos no processo de transformação social”.

A análise do estudo do Banco Mundial e dos documentos produzidos pelos atores sociais envolvidos com o licenciamento ambiental de hidrelétricas expõem um conjunto de discursos que no seu conjunto compõem uma obra de arte pós-moderna: fragmentada, sem padrão estético e orientados à satisfação do emissor.

Os pontos de convergência são poucos ${ }^{125}$, mas mesmo naquilo em que concordam, o fazem sob pontos de vista contrários, de maneira que, ainda que concordem na conclusão, o acordo seria difícil, pois os diagnósticos que embasam tais conclusões se auto-excluem.

Há grita generalizada sobre onde reside a responsabilidade pelos problemas e até de quais são realmente os problemas. Acerteza comum é de que os problemas residem na atuação e papel desempenhados pelo outro, quando muito, os atores podem reconhecer certo "exagero" por parte de seus pares.

A falta de sintonia é tão grande que podemos encontrar nas entrelinhas das falas dos diversos atores conteúdos discursivos idênticos, mas construídos sob óticas completamente diferentes. Aineficiência do licenciamento, por exemplo, está nas falas do movimento social e empreendedores, mas por motivos opostos.

Para os empreendedores, por ser um instrumento no qual os ideólogos se apóiam para tentar impedir a construção de UHEs. Para o movimento social porque não há rigor no licenciamento já que o empreendedor controla os estudos técnicos através da consultoria que ele paga e que via de regra fazem trabalhos ruins que acabam sendo aceitos e o empreendimento licenciado pelo IBAMA.

A razão para essa falta de sintonia, mesmo naquilo em que concordam, tem relação com o fato de no licenciamento ambiental ecoarem vozes e sentimentos do embate a respeito da disputa dos projetos de sociedade e de país.

\footnotetext{
${ }^{125}$ Um exemplo emblemático dessa realidade é o próprio estudo do Banco Mundial e o debate dentro do governo entre os Ministérios do Meio Ambiente e Minas e Energia. O MMA (2008), em nota técnica, considerou que o estudo, ainda que tenha qualidade e acertos comete um equívoco capital ao considerar o Licenciamento Ambiental um entrave. O MME (2008), também em nota técnica e provavelmente em resposta ao parecer da pasta ambiental, subscreveu o trabalho do organismo internacional.
} 
O licenciamento de grandes empreendimentos e de UHEs especificamente é discutido a partir da percepção que cada grupo econômico ou social tem do projeto de país que espera estar construindo em sua ação cotidiana. Ainda que haja concretude nos impactos socioeconômicos e ou socioambientais, a discussão que o licenciamento faz, na verdade, é a respeito do balanço entre custos socioambientais e crescimento econômico.

O ambiente de embate tal como tem acontecido, favorece que os empreendimentos, depois de um longo e exaustivo processo, sejam licenciados, mesmo que às vezes não tenham a qualidade socioambiental desejada por amplas parcelas da sociedade.

A maneira como o sistema funciona hoje está vulnerável aos maus projetos, porque ao largo do embate entre contrários e defensores dos empreendimentos o país tende sempre a crescer, temos uma massa de cidadãos a serem incorporados ao mercado de consumo e isso demanda mais infra-estrutura, principalmente energética.

Na medida em que o sistema de licenciamento não consegue criar mecanismos que tenham como produto o necessário consenso a respeito do que deve ou não ser licenciado e sob quais condições, por um lado o país cresce, e por outro, a tendência é que tenhamos empreendimentos ruins do ponto de vista socioambiental, e as UHEs das indústrias de alumínio são um claro exemplo de como as coisas podem ficar muito ruins se o sistema não avança para a construção de acordos em torno da agenda de licenciamento.

Pressionadas por um mercado que só cresce ${ }^{126}$ e pela necessidade da eletricidade em seu processo produtivo, as indústrias têm construído hidrelétricas, nas quais a relação MW gerado por área alagada tem diminuído significativamente.

Essa é a questão central desse debate. Enquanto não conseguimos avançar no necessário diálogo orientado a produzir consenso, a engrenagem está rodando e o ambiente perdendo. Ainda que haja concordância de que há problemas referentes ao licenciamento, mas tem-se produzido melhoras nos empreendimentos para mitigá-los, a questão a se perguntar é: e se tivéssemos outro agir sistêmico,

\footnotetext{
${ }^{126}$ Ao menos até o início da crise econômica mundial em setembro de 2008.
} 
oxigenado pelo diálogo e orientado ao entendimento, não teríamos melhores arranjos socioambientais nos processos produtivos ou nas características técnicas dos projetos de infra-estrutura?

Apresentamos no primeiro capítulo o ambiente anterior à emergência da modernização ecológica na Europa, quando a falta de diálogo e o embate entre ambientalistas, Estado e setor produtivo produziu o que Mol (2001) caracterizou como desastre das políticas ambientais.

A audiência pública tem sido o único momento no qual os diversos interesses que gravitam em torno de determinado empreendimento se encontram para dialogar sobre o mesmo ${ }^{127}$.

A inclusão no debate dos interesses locais só na AP tenciona todo o processo uma vez que o movimento social, ONGs e o poder político local ficam alijados da discussão durante maior parte do tempo e sem poder opinar e mesmo sem ter informações sobre questões que lhes dizem respeito, buscam intervir por caminhos externos ao licenciamento.

No momento da audiência pública toda tensão que se acumula na relação entre empreendedor, comunidade, poder público e sociedade civil é manifesta e o que deveria ser debate, vira embate.

A situação é agravada pela falta de previsibilidade que as populações atingidas têm em relação aos programas mitigatórios e compensatórios. Para pleitear a Licença Prévia, o empreendedor não precisa detalhar estas ações. O resultado prático é que as pessoas ficam sem saber ao certo o que acontecerá de fato com suas vidas. A falta de clareza sobre os programas traz mais tensão para os ambientes de audiência, que ficam comprometidos em sua função precípua de servir como momento de esclarecimento do projeto ${ }^{128}$.

Quando da realização das audiências, as principais decisões relacionadas ao empreendimento já estão

${ }^{127}$ Há casos em que houve audiências públicas anteriores a emissão do TR. As UHEs do Rio Madeira tiveram participação social na elaboração do Termo de Referência. Mas são situações isoladas e não previstas na lei ou nas inúmeras resoluções que normatizam o licenciamento ambiental.

${ }^{128} \mathrm{O}$ debate público a respeito dos empreendimentos licenciáveis se dá apenas no momento anterior a emissão da licença prévia. Como a legislação desobriga o empreendedor de detalhar os programas para essa fase, e depois não há na legislação outra oportunidade de participação das populações atingidas pelo empreendimento, estas ficam sem ter canais efetivos de influenciar na definição dos programas que lhes dizem respeito. O FBOMS sugere que ocorram audiências públicas antes da emissão da licença de operação e na renovação desta de maneira que o órgão licenciador possa, em diálogo com a sociedade, averiguar o cumprimento dos compromissos assumidos durante o licenciamento pelo empreendedor. Essa reivindicação, ao menos em relação às hidrelétricas tem sintonia com o Relatório da Comissão Mundial de Barragens que afirma ser um problema o cumprimento dos compromissos assumidos pelo setor. 
tomadas, de maneira que dificilmente as contribuições vindas do embate irão influenciá-lo. Mais um fator gerador de tensão é a percepção de que o licenciamento tem formato que privilegia o empreendimento em detrimento dos interesses locais.

Ao refletir sobre a participação da sociedade civil na gestão ambiental, Pedro Jacobi (2005) afirma que:

Os mecanismos para a democracia deliberativa relacionados com questões ambientais, embora tenham avançado, ainda não incorporaram os grupos sociais normalmente excluídos dos mecanismos tradicionais de deliberação como atores que têm presença nos processos decisórios.

O licenciamento ambiental está caracterizado por esta dificuldade. O paradoxo é que em outras instâncias sociais, sobretudo os conselhos formuladores de políticas públicas nas áreas de saúde, educação, transporte, infância etc, esses mesmos grupos têm tido experiência crescente de participação no processo de tomada de decisão.

Em que pese as vicissitudes do licenciamento, é um instrumento que precisa ser revisado na maneira da sua aplicação para que se incorporem os avanços ocorridos em torno da participação social no processo de tomada de decisão sobre a construção e gestão de políticas de interesse social. Essa situação corrobora com a afirmação do estudo do Banco Mundial de que faltam modificações na legislação sobre licenciamento ambiental que atualizem o instrumento.

No texto com título "Os fundamentos da organização burocrática: uma construção de tipo ideal”, Max Weber (1966) dirá que a burocracia é o sistema capaz de dar escala ao processo administrativo de massas. Para o autor o processo administrativo "é a busca racional dos interesses, especificados nas ordenações do corpo social".

Nesse sentido o sistema de licenciamento carece de maiores investimentos, sobretudo na contratação de novos analistas ambientais. Mais formação do quadro de servidores, melhor definição e clareza das competências, responsabilidades e estabelecimento de prazos.

A qualidade dos Estudos de Impacto Ambiental é um problema não só no Brasil como vimos através dos estudos do Banco Mundial, do Ministério Público e inúmero estudos acadêmicos discutidos no capítulo 2. De acordo com Sánchez (2006, p.388-394) estudos feitos sobre a qualidade de EIA no Canadá, EUA, Grã-Bretanha e Austrália identificaram problemas na realização desses estudos. Na 
Europa, no final da década de 90, estudos concluíram a ocorrência efetiva de melhoras na qualidade desses estudos. No entanto, na Holanda, $40 \%$ dos estudos de impacto apresentam algum problema.

Está claro que para além dos problemas do sistema de licenciamento, a produção dos Estudos de Impacto Ambiental é um problema não só no Brasil. Essa situação desafia as consultorias responsáveis por EIAs. Porque os estudos não têm a qualidade desejada e resta saber até quando terão que ser complementados, ou devolvidos por falta de qualidade técnica? ${ }^{129}$

A iniciativa da criação da EPE pode contribuir para a melhoria dos Estudos de Impacto Ambiental. É preocupante que o consórcio vencedor da licitação do aproveitamento Jirau tenha mudado a localização do eixo da barragem em 7 KM. A situação sugere dois tipos de reflexão:

I. Os estudos contratados pela EPE eram ruins e a alternativa locacional não era a mais adequada;

II. Os estudos contratados pela EPE e que orientaram o Edital eram bons e corretos, no entanto o Consórcio liderado pelo grupo Suez, seguiu uma lógica muito presente no setor elétrico de orientar a localização dos empreendimentos apenas por critérios econômicos.

O fato em si desmoraliza a iniciativa estatal de se responsabilizar pelos estudos que culminam com a licença prévia. A mudança da localização do empreendimento jogou dúvidas sobre a competência da EPE na coordenação dos estudos de impacto que no caso das usinas do Rio Madeira foram realizados por um consórcio entre a Construtora Norberto Odebrecht e a estatal do setor elétrico Furnas.

O ocorrido na UHE Jirau é um claro exemplo das dificuldades existentes em torno da mudança cultural necessária ao sistema de licenciamento. Não só a mudança do local do barramento, mas o comportamento do governo, que considerou legal que estivesse licitando um empreendimento para determinada

\footnotetext{
${ }^{129}$ Ao tratarmos dessa questão, o advogado do ISA, Raul do Valle, sugeriu uma espécie de cadastro negativo das consultorias com maus estudos. Para o advogado, ao criar um cadastro de empresas que fizeram maus estudos ou de empreendedores que utilizaram-nos, o governo estimularia que a concorrência procurasse se diferenciar. Para Raul, quem constasse no cadastro, deveria ter menos facilidades do que as empresas sem problemas com a elaboração e utilização de EIAs.
} 
localidade e o vencedor apresentasse proposta para uma outra localidade. Uma clara subversão do Edital que licitou o aproveitamento e da licença prévia já emitida ${ }^{130}$.

\section{ALGUMAS PROPOSTAS}

Do ponto de vista da ME é necessário que ocorram mudanças no sistema de licenciamento de maneira que o processo deixe de ser orientado pelo embate e passe a ser conduzido pela perspectiva do diálogo orientado pelo acordo.

Nesse sentido propomos algumas iniciativas:

1) Realização da avaliação ambiental estratégica - AAE, para as regiões e localidades com potencial para abrigar empreendimentos de infra-estrutura ou indústrias licenciáveis. A AAE pode se constituir em importante instrumento para avaliar as diversas potencialidades das regiões e em um processo participativo discuti-las à luz dos variados interesses presentes ou desejos de atuar em cada território. A avaliação ambiental cumpriria o papel de se antecipar aos conflitos ambientais, assim como, serviria de espaço para que a partir de um processo de interação e diálogo, surgissem os necessários acordos que falamos nesse texto.

2) Criação para cada licenciamento do GTL (Grupo de Trabalho do licenciamento) - O licenciamento passa incorporar a participação social desde o início do processo, na definição do termo de referência e processualmente na criação do GTL do qual farãoparte consultores, órgão licenciador e representantes das populações atingidas pelo empreendimento, movimento social local e poder público local. O grupo não terá poder deliberativo, mas será uma instância de discussão processual do EIA, que será apresentado para debate à medida que tiver suas partes prontas. OGTL acompanhará oempreendimento até a emissão da licença de operação e será convocado quando da renovação da mesma.

\footnotetext{
${ }^{130}$ Acreditamos que essa situação é significativa da discussão que fizemos no capítulo 3 de que pressionado pela entrada de novos MW na matriz energética, os governos acabam por referendar projetos de qualidade socioambiental duvidosa. Afinal, se havia um estudo já tramitado nas esferas legais e já possuidor de licença, porque aceitar uma proposta para outra localidade?
} 
3) Definição de uma agenda de discussão para as audiências públicas ${ }^{131}$ - Com a criação do GTL e o acompanhamento e debate contínuo do EIA, a pauta da audiência pública poderá se restringir àqueles pontos que não houve acordo ou que por sua complexidade e ou importância carecem de conhecimento público. A pauta das audiências será indicada pelas instituições ou grupo de cidadãos que solicitarem a realização da mesma.

4) Os programas compensatórios e mitigatórios passarão a ser discutidos já para a emissão da licença prévia. Essa iniciativa trará ao licenciamento maior previsibilidade por parte dos atingidos a respeito do que lhes acontecerá, diminuindo o potencial de conflito durante as discussões dos empreendimentos.

${ }^{131}$ Em Quebec as audiências públicas são solicitadas por cidadãos que antes da realização das mesmas são convidados a conversar com o órgão licenciador e empreendedor. A audiência propriamente é realizada em dois momentos, de maneira que entre a primeira e segunda parte, espaçadas por 21 dias, todos têm a oportunidade de refletir sobre o primeiro bloco do debate, consultar eventuais documentos, estudos, pareceres, etc. A previsibilidade do que será discutido traz mais racionalidade e foco à plenária. 


\section{Bibliografia:}

ACSELRAD, H ET AL (Orgs) Justiça ambiental e cidadania Rio de Janeiro: Relume Dumará, 2004

ABDIB. Inviabilidade ambiental: equívocos e riscos In: Análise Infra-estrutura Boletim, Ano II, $\mathrm{n}^{\circ}$ 5, maio de 2007.

ALOSON JÚNIOR, H. Direito Fundamental ao Meio Ambiente e Ações Coletivas, São Paulo, Editora Revista dos Tribunais, 2006.

ANEEL, Acompanhamento das Usinas Hidrelétricas. Brasília, 2005. ANEEL, Legislação Básica do Setor Elétrico Brasileiro. Brasília, 2000.

ARAÚJO, B.; Souza, J. de A. Desafios Para a Reflexão do Setor Elétrico: Políticas Públicas e Sociedades (orgs). São Paulo: NAIPPE/USP, 1993.

AVRITZER, L. A Moralidade da democracia: ensaios em teoria habermasiana e teoria democrática. São Paulo: Belo Horizonte: Perspectiva, UFMG, 1996.

O Orçamento Participativo: As experiências de Porto Alegre e Belo Horizonte. In: Dagnino, Evelina (org). Sociedade Civil e Espaços Públicos no Brasil. São Paulo: Paz e Terra, 2002.

BAKHTIN, M. M. Marxismo e Filosofia da Linguagem: problemas fundamentais do método sociológico na ciência da linguagem. São Paulo: Hucitec, 1986.

BANCO MUNDIAL - Licenciamento Ambiental de Empreendimentos Hidrelétricos no Brasil: Uma Contribuição para o Debate. Volume I: Relatório Síntese, 2008.

BARROS, J. N., SYLVESTRE, M.-E. Atingidos e Barrados: as violações de direitos humanos na hidrelétrica Candonga. Rio de Janeiro: Justiça Global; Ed. Ponte Nova, 2004.

BECK,U. La política de la sociedad de riesgo. In: franklin, J. The Politics of Risk Society, Oxford, Polity Press, 1998. 
BERMANN, C. A energia elétrica incorporada na exportação. São Paulo: Livre-docência IEE/ USP, 2006.

Impasses e controvérsias da hidreletricidade, In: Dossiê Energia, Estudos Avançados 59, São Paulo, vol.21-no 59, Janeiro/abril 2007.

O Circuito do Alumínio e a Hidreletricidade. São Paulo: Pós-doutorado IEE/

USP, 1993.

Parecer Técnico. Relatório de Impacto Ambiental: Aproveitamento Hidrelétrico Tijuco Alto. São Paulo, 1993.

Self-managed ressettlement - case study of Itá dam in Brazil. In: Proceedings of the International Conference "Hidropower into the next century". Barcelona, International Journal on Hydropower \& Dams, 1995. Págs. 149-158.

BERMANN, C. e CAMARGO, R. L. Qual Influência Pode Exercer a Recém-Criada Empresa de Pesquisa em Energia (EPE) no Processo de Licenciamento Ambiental. In: Políticas de Desenvolvimento Científico Tecnológico para o Setor Energético, X Congresso Brasileiro de Energia, CBE, 26-28 de outubro de 2004.

BOBBIO, N. A grande dicotomia: público/privado In: Estado, Governo, Sociedade: para uma teoria geral da política. Rio de Janeiro: Ed. Paz e Terra, 1987. págs 11-13.

BRASIL, EPE. Análise e Revisão do consumo de energia na indústria de Alumínio e Alumina. Rio de Janeiro: EPE, 2006.

A questão socioambiental no planejamento da expansão da oferta de energia elétrica. Rio de Janeiro: EPE, 2006.

Mercado de Energia elétrica 2006 -2015. Rio de Janeiro: EPE, 2005.

BRESSER, P. O público-não estatal na reforma do estado. Rio de Janeiro: FGV, 1999.

BUTTEL, F. H. Classical Theory and Contemporary Environmental Sociology: some reflections 
on the antecedents and prospects for reflexive modernization theories in the study of environment and society, In: SPAAGAREN, G., MOL, A. PJ, Environment and Global Modernity, London, Sage publications Ltd, 2000.

CASTRO, E. V. de. Hidrelétricas do Xingu: o Estado Contra as Sociedades Indígenas, In: SANTOS, L. de O., ANDRADE, L. M. M. As Hidrelétricas do Xingu e os Povos Indígenas. São Paulo: Comissão Pró-Índio,1988.

CASTRO, E. V. Território, Biodversidade e Saberes de Populações Tradicionais. In: DIEGUES, A. C. (org). São Paulo: Ed. Hucitec, 2000.

CHABARIBERY ET AL. Perfil socioeconômico e ambiental do Vale do Ribeira-SP. In: WORLD CONGRESS OF RURAL SOCIOLOGY, 10, Rio de Janeiro, Anais, IRSA, 2000. 1 CD-ROM.

COELHO,V.S.P., FAVARETO,A. GALVANEZZE,C. MENINO, F. As regras do jogo e o jogo das regras-movimentos sociais, governança ambiental e desenvolvimento territorial no Vale do Ribeira(Brasil). 16/12/2005. Artigo retirado www.rimisp.org/getdoc.php?docid=5206. COELHO,V.S.P.(coord), FAVARETO,A., MONTEIRO, M.M. GALVANEZZE,C. MENINO, F. Barragem de Tijuco Alto: Emprego, recursos naturais e direitos das comunidades tradicionais em debate nos fóruns participativos do Vale do Ribeira. Relatório de Pesquisa-Junho de 2005, São Paulo, 2005.

COElHO,V.S.P., FAVARETO,A. GALVANEZZE,C. MENINO, F. Fóruns Participativos e Desenvolvimento Territorial no Vale do Ribeira(Brasil) Artigo retirado www.Rimisp.org/ getdoc.php?docid $=5326$.

CONSTITUIÇÃO DA REPÚBLICA FEDERATIVADO BRASIL. Brasília: Congresso Nacional, 1988.

CONTRAPONTO - Instituto de Análise Social e Políticas Públicas. Observações Preliminares sobre a comunidade de Porto Cori e de suas impressões sobre a UHE de Irapé. Belo Horizonte, 2001.

DAGNINO, E. Os movimentos sociais e a emergência de uma nova noção de cidadania. In: 
Dagnino, Evelina (org.). Anos 90 Política e Sociedade no Brasil. São Paulo: Brasiliense, 1994.

Sociedade Civil, Espaços Públicos e Construção Democrática no Brasil: Limites e

Possibilidades. In: Dagnino, Evelina (org). Sociedade Civil e Espaços Públicos no Brasil. São Paulo: Paz e Terra, 2002.

DIAS, M. A. \& MACHADO, E. L. Princípios do Equador: Sustentabilidade e Impactos na conduta ambiental dos bancos signatários brasileiros. São Paulo, 2007.

DUPAS, G. Tensões Contemporâneas Entre o Público e o Privado. São Paulo: Paz e Terra, 2003.

GUIVANT, J. S. Apresentação do Dossiê Mapeando os caminhos da Sociologia Ambiental In: Política e Sociedade. Número 7, p. 09-25, outubro de 2005

International Rivers Network, Barragens e Desenvolvimento: Um Novo Modelo para Tomada de Decisões. In: TENOTÃ-MÕ: Alertas sobre as consequiências dos projetos hidrelétricos no rio Xingu. SEVÁ FILHO A.O. (Org) São Paulo, Earthscan Publications Ltd, 2005, pags 301-314.

ELETROBRÁS, II Plano Diretor do Meio Ambiente - PDMA, 1992

FBOMS, “Comentários do GTEnergia sobre o plano decenal de expansão da energia elétrica 2006-2015”. Brasília, 2006.

"Perspectiva do FBOMS quanto ao Acordo de Cooperação com o MMA referente aos procedimentos do Licenciamento Ambiental”. Brasília, 2006.

“Sugestões do GTE/FBOMS para o aprimoramento das regras de licenciamento ambiental”. Brasília, 2006.

FISCHER, R.M. Alianças Estratégicas Intersetoriais, São Paulo, CEATS, 2002.

FUNDAÇÃO CULTURAL PALMARES. Análise dos relatórios de Impactos Ambientais referentes a Construção da Usina Hidrelétrica Irapé Sobre a Comunidade de Porto Cori, Brasília, Ministério da Cultura. 
FURRIELA, Rachel. Democracia, cidadania e proteção do meio ambiente. São Paulo: Annablume, 2002.

GOLDEMBERG, J. Energia para o Desenvolvimento. Trad. $2^{a}$ ed. São Paulo, T. A. Queiroz editor, 1988.

Energia, Meio Ambiente \& Desenvolvimento. $2^{\text {a }}$ ed. São Paulo, EDUSP, 2003.

HABERMAS, J. Mudança Estrutural da Esfera Pública. Rio de Janeiro: Tempo Brasileiro, 1984.

HAJER,M.A. Ecological Modernisation as Cultural Politics, In: YEARLEY, S. Sociology, Environmentalism, Globalization: Reinventing the Globe, London, Sage Publications, 1996.

IBAMA. Parecer técnico Nº7/2008. COHID/CGENE/DILIC/IBAMA, Brasília, 2008.

INSTITUTO OBSERVATÓRIO SOCIAL. Os Princípios do Equador. Florianópolis, 2004.

Panorama Internacional e Nacional do Setor de Alumínio, 2006.

JACOBI, P.R. Governança institucional de problemas ambientais Política e Sociedade.

Florianópolis Número 7, p. 119-137, outubro de 2005,

Prefácio in: FURRIELA, R. B. Democracia, cidadania e proteção do meio ambiente.

São Paulo: Annablume, 2002

Políticas Sociais e Ampliação da Cidadania. Rio de Janeiro: FGV, 2000.

JACOBI, P. R. e FERRER, J. T. V. Política e gestão ambiental: a audiência pública, uma nova fronteira no espaço cidadão: período de 1988 a 2001. In: MANTOVANI, W. (Org.). Caminhos de uma ciência ambiental. São Paulo, Annablume, Fapesp, 2005.

JAMISON, A. The Shaping of the global environmental agenda: the role of non-governamental organizations, In: LASH, S., SZERSZYNSKI, B., WYNNE, B. R., Environmenta and Modernity: Towards a New Ecology, London, Sage publications Ltd, 1998. 
Change. In: Jacob, K. Binder, M. and Wieczorek, A. (eds), Governance for industrial Transformation. Proceedings of the 2003 Berlin Conference on the Human Dimensions of Global Environmental Change, Environmental policy Research centre: Berlin, 2004, pag.201-207.

JERONYMO, A.C.J. Deslocamentos de populações ribeirinhas e passivos sociais e econômicos decorrentes de projetos de aproveitamento hidrelétrico: a UHE Tijuco Alto/SP-PR, São Paulo, Dissertação de Mestrado- Programa Interunidades de Pós-Graduação em Energia, USP, 2007.

LENZI, C.L. Para Uma Imaginação Sociológica da Ecologia: Uma Análise do pensamento de Anthony Giddens. In: Ambiente \& Sociedade, Vol.IX Jan/Jun.2006.

Sociologia Ambiental: risco e sustentabilidade na modernidade, Bauru, Edusc, 2006.

LEROY, P. \& BLOWERS. A. Political Modernisation, Environmental Policy and Political Inequality. Montreal: $14^{\circ}$ ISA Conference, 1998.

MILARÉ, E. Direito do Ambiente: doutrina, jurisprudência, glossário. São Paulo, Editora Revista dos Tribunais, 2004.

MILLS,C.W. A Imaginação Sociológica. Rio de Janeiro, Editores Zahar, 1975.

MINISTÉRIO DAS MINAS E ENERGIA. Balanço energético Nacional - BEN 2004. Brasília, MME, 2005.

Nota Informativa 01/2008 NESSA/SE/MME. Brasília, 2008.

MINISTÉRIO DO MEIO AMBIENTE. Avaliação de Impacto Ambiental: Agentes Sociais, Procedimentos e Ferramentas. Brasília, 1995.

Acordo de Cooperação Técnica n 003/2005. Brasília, 2005.

Parecer nº 001/2008. Brasília, 2008.

Protocolo de Intenções pela Responsabilidade Socioambiental. Rio de Janeiro, 2008. 
MINISTÉRIO PÚBLICO FEDERAL. Deficiências em Estudos de Impacto Ambiental: Síntese de uma Experiência, Brasília, Escola Superior do Ministério Público da União, Maio 2004.

Termo de Acordo. Belo Horizonte, 2002.

MIRRA, A.L.V. Impacto Ambiental: Aspectos da Legislação Brasileira. São Paulo, editora Juarez de Oliveira, 2006.

MOL, A. P.J. Ecological Modernization: From National Emergence to Global Maturation. In: MOL, A.P.J Globalization and Environmental Reform: The Ecological Modernization of the global economy, London, MIT Press, 2001.

Ecological Modernization Around the World: An Introduction, In:

Environment Politics ,9(1)3-16, Spring 2000.

MOL, ARTHUR P. J. Ecological modernization: industrial transformation and enviromental reform. In: REDCLIFT \& WOODGATE. Concepts and theories in enviromental sociology, 1997.

MOL.A.P.J. and SPAARGAREN, G. Ecological Modernization Theory in debate: a review, Paper presented at the $14^{\text {th }}$ World Congress of Sociology, Montreal, July, 1998.

MOL and SONNENFIELD, D.A. Ecological Modernization Around the world: An introduction Enviromental Politics 9(1):3-16,Spring ,2000.

MONTEIRO, A. J. L. C. \& Ferreira, E.C. Princípios do Equador-A crescente preocupação das instituições financeiras com o meio ambiente. Pinheiro Neto Advogados. Anexo Biblioteca Informa, $\mathrm{n}^{\mathrm{o}} 1955,2007$.

MORENO, J. “Comunidades Quilombolas do Vale do Ribeira” In: Linguagens. Revista Eletrônica, $\mathrm{n}^{\mathrm{o}} 3$, junho 2006.

OLIVEIRA, A. I. de A. Introdução à legislação Ambiental Brasileira e Licenciamento Ambiental. Rio de Janeiro, Editora Lumen Júris, 2005.

PAOLI, M. C. Empresa e Responsabilidade Social: os enredamentos da cidadania no Brasil, IN: BOAVENTURAS. S. (org). Democratizar a Democracia: Os caminhos de democracia participativa. 
Rio de Janeiro: Civilização Brasileira, 2002. Pgs. 373-418.

PELIANO, A. M. T. A iniciativa privada e o espírito público. Brasília: IPEA, 2003.

PIRES, J. T. Alianças Estratégicas Entre Empresas Privadas e Órgãos Públicos Para a Atuação Social: um estudo sobre a influência em políticas públicas, São Paulo, Dissertação Mestrado USP, 2004.

PRESIDÊNCIADAREPÚBLICA-CASA CIVIL, Grupo de Trabalho Interministerial-Atingidos por Barragem. Relatório Final. Brasília, 2004.

REIS, L. B. Energia Elétrica para o Desenvolvimento Sustentável, São Paulo, EDUSP, 2001. ROMÃO, D.A.(org). Vale do Ribeira: Um ensaio para o desenvolvimento das Comunidades Rurais, Brasília, Ministério do Desenvolvimento Agrário, Núcleo de Estudos Agrários e Desenvolvimento Rural, (NEAD Debate; 11)2006.

ROMÃO D. A. ET AL. Fortalecimento de Comunidades Rurais no Brasil: um estudo regional. Informações Econômicas, São Paulo, Vol. 35, nº 2, fevereiro 2005

ROSA, E. A. Modern Theories of Society and the Environment: the Risk Society, In: SPAAGAREN, G., MOL, A. PJ, BUTTEL, F. H. (ORGS). Environment and Global Modernity, London, Sage publications Ltd, 2000.

ROSA, L. P. Geração hidrelétrica, termelétrica e nuclear. In: Estudos Avançados 59. Universidade de São Paulo. Instituto de Estudos Avançados. Vol. 21, nº 59. Jan/Abril 2007.

ROUSSEFF, D. A Política Energética e Mineral na estratégia de desenvolvimento sustentável, Brasília, Ministério das Minas e Energia, 2004.

SÁCHEZ, L. E. Avaliação de impacto ambiental: conceitos e métodos. São Paulo: Oficina de Textos, 2006.

Simpósio sobre Avaliação de Impacto Ambiental : Situação Atual e Perspectivas (1991 : São Paulo). Avaliação de impacto ambiental : situação atual e perspectivas ; textos apresentados e debates / [coordenação de] Luis Henrique Sanchez. São Paulo : Epusp, 1993. 
SACHS, I. A revolução energética do século XXI. In: Estudos Avançados 59. Universidade de São Paulo. Instituto de Estudos Avançados. Vol. 21, nº 59. Jan/Abril 2007.

SALGADO, F. G. de A. Estudo de Impacto Ambiental uma avaliação crítica. In JACOBI, P. R. (org.). Ciência Ambiental Os desafios da interdisciplinaridade. São Paulo: Annablume, Fapesp, 1999.

SAUER, I. L.(org et al.) A reconstrução do setor elétrico brasileiro. São Paulo, Paz e Terra, 2003.

SIGAUD, L. Efeitos sociais de Grandes Projetos hidrelétricos, comunicação ${ }^{\circ} 9-$ Museu Nacional, 1986.

SIGEL.ANEEL.GOV.BR - Sistema de georreferenciamento do sistema elétrico brasileiro.

SPAAGAREN, G. Ecological Modernization Theory and the Changing Discourse on Environment and Modernity, In: SPAAGAREN, G., MOL, A. PJ, BUTTEL, F. H. (ORGS). Environment and Global Modernity, London, Sage publications Ltd, 2000.

SOUZA, A. N. \& JACOBI, P.R. A indústria do alumínio no Brasil e suas hidrelétricas sob a perspectiva da modernização ecológica. IX Engema, Curitiba, 2007.

“Licenciamento Ambiental e o Novo Ambiente Político e Cultural do PósDitadura: o Caso da UHE Tijuco Alto". IV ANPPAS, Brasília, 2008.

TATAGIBA, L. Os Conselhos Gestores e a democratização das políticas públicas no Brasil. In: DAGNINO, E. (org). Sociedade Civil e Espaços Públicos no Brasil. São Paulo: Paz e Terra, 2002.

TEIXEIRA, A. C. C. A atuação das Organizações Não Governamentais: entre o Estado e o conjunto da sociedade. In: DAGNINO, E. (org). Sociedade Civil e Espaços Públicos no Brasil. São Paulo: Paz e Terra, 2002.

TOLMASQUIN, M. Fontes renováveis e o Meio Ambiente. Apresentação no Fórum Estadão de Energia.06/2006. Apresentação em power point.

TUNDISI, J. G. Exploração do potencial hidrelétrico da Amazônia. In: Estudos Avançados 59. Universidade de São Paulo. Instituto de Estudos Avançados. Vol. 21, nº 59. Jan/Abril 2007. 
VAINER, C. B. O conceito de Atingido: Uma revisão do debate e diretrizes. Rio de Janeiro, IPPUR/UFRJ, 2003.

Recursos hidráulicos: questões sociais e ambientais. In: Estudos Avançados 59.

Universidade de São Paulo. Instituto de Estudos Avançados. Vol. 21, nº 59. Jan/Abril 2007.

WEBER, M. Os fundamentos da organização burocrática: uma construção de tipo ideal In:

Campos, E. Sociologia da burocracia. Rio de Janeiro: Zahar Editores. 1966

WEINGRILL, C. (COORD.) Práticas Empresariais de Responsabilidade Social: relação entre os princípios do Global Compact e os indicadores Ethos de Responsabilidade Social Empresarial, São Paulo, Instituto Ethos, 2003.

WORD BANK. Enviromental Sustainabiity in the Hydro Industry: Disaggregating the debates. In: LARGEDAMS, Learning from the past, looking at the future. Washington D. C.: Gland Switzerland, 1997.

WWF. A Repotenciação de Usinas Hidrelétricas Como Alternativa Para o Aumento da Oferta de Energia no Brasil com Proteção Ambiental. Série técnica, Volume X - Agosto de 2004.

ZHOURI, A., LACHEFSKI, K, PEREIRA, D. B. (orgs). A insustentável leveza da política ambiental. Belo Horizonte: Ed. Autêntica, 2005.

\section{JORNAIS:}

WIZIACK, J. \& BRITO, A. Bancos desistem de projetos do Madeira. Folha de S. Paulo, 18/12/ 2008, Caderno Dinheiro.São Paulo.

VALOR ECONÔMICO, Setorial Energia. São Paulo, novembro de 2004

\section{REVISTAS:}

ÉPOCA NEGÓCIOS. MORAES ET AL. O Desafio da Terceira Geração. Revista Época Negócios, no 22/dezembro de 2008, págs.102-123.

ISTO É DINHEIRO- MORAES,A. E. A empresa do ano CBA, São Paulo, Revista Isto É Dinheiro, 526-24/10/2007( Pags 58-65) 


\section{SITES:}

www.abdib.org.br - Associação Brasileira da Indústria de Base

www.aneel.gov.br/fiscalização - Agência Nacional de Energia Elétrica

WWW.fboms.org.br - Fórum Brasileiro de ONG`s e Movimentos Sociais para o Meio Ambiente e

Desenvolvimento

www.IBAMA.gov.br - Instituto Brasileiro do Meio Ambiente

www.idesc.org.br -Instituto para o Desenvolvimento Sustentável e Cidadania do Vale do Ribeira

www.os.org.br - Instituto Observatório Social

www.rimisp.org.br

www.socioambiental.org - Instituto Sócio Ambiental

www.sosma.org.br - SOS Mata Atlântica

www.Tijucoalto.com.br - Site Institucional 